\title{
PALNEDNTOLDEY OF THE
}

\section{PROVXNER OR ONMARTO.}

NXEXOLSON. 


\section{HARVARD UNIVERSITY}

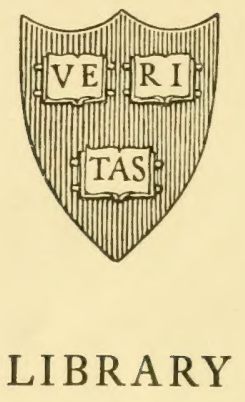

OF THE

MUSEUM OF COMPARATIVE ZOÖLOGY

$$
\text { Mineralogy Library }
$$

April 21, 1941 
Dept of reangy 





\section{R E POR T}

\section{vrox $\operatorname{trl}$ \\ P A L A O N T O L O G Y \\ of $\mathrm{THK}$}

\section{PROVINCE OF ONTARIO.}

. BY

HENRY ALLEYNE NICHOLSON, ESQ., M.D., D.Sc., F.R.S.E PROFESSOR OF NATURAL HISTORY, UNIVERSITY OF TORONTO.

Presented to the Legislative Assembly by command of His Excellency the Lieutenant-Governor.

TORONTO:

PRINTED BY HUNTER, ROSE \& CO., 86 \& 88 KING STREET WEST. 


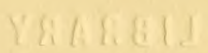

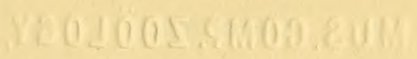

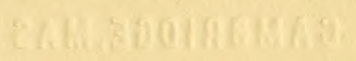

seum of Compology
Zoology

APR 211941

IIBRARY

Mineralogy Lilerary 
To the Honourable the Secretary of the Province of Ontario.

SIR,--I have the honour to submit to you, for the information of His Excellency the Lieutenant-Governor in Council and the Legislature, the following Report upon the Palæontology of the Province of Ontario, embracing descriptions and figures of the organic remains of the Devonian formation of Western Canada.

In addition to the collections which, by the liberality of the Legislature, I was enabled. to wake from the Devonian rocks, I also examined and formed collections from various portions of the Silurian series. The description of these, however, I must in the meanwhile hold over, partly because of their being still incomplete, and partly on account of my own want of leisure.

In addition to the collection which I have placed in the Museum of the University, I have also placed examples of the more typical Devonian fossils in the Museum of the College of Technology.

I have the honour to be, Sir,

Your most obedient servant,

H. Alietne Nicholson.

University College, Toronto,

Oetober, 1873. 



\section{PREFACE.}

The following Report contains descriptions. for the most part accompanicd by figures. of the fossils which I collected durine the year 1873, in the Deronian rocks of Western Canada, by the help of a grant set apart for this purpose by the (iosernment of Ontario. In some few cases, for the sake of completeness, I have also included dexcriptions of remains which I hare collected upon other occasions from the same deposits, but which did not come under my notice during the investigation of which this is a special record.

The collections herein described were mainly made from the inferior portion of the Devonian series (Oriskany sandstone and ('orniferous Limestone); but the Hamiltou group was likewise, though less carefully, examined.

The time and means at my dicyosal being both limited, I thought it adrisable rather to make a careful and prolonged examination of the fauna of a limited district, than to make less exhaustive collections from a wider areat and from seattered localities. In accordance with this view, I repeatedly and very carefully examined the various fossiliferous localities in the Devonian rocks of the Townships of Wainfleet, Humberstone. and Bertie, in the ('ounty of Welland, on the north shore of Lake Eile. I also visited, more hurriedly, the same deposits further to the west, as they oceur in the Townshins of Oneida and Walpole, in the County of Haldimand.

In investigating the remains of the Corniferous and IIamilton formations, it is hardly necessary for me to remark that I have been very greatly indebted to the various memoirs and works upon this subject by Mr. Billings and Prof. James Hall. The wood engrarings, with two exceptions, and all the figures in the lithographic plates which accompany this work, are original.

\section{University College, 'Toronto,} October, 1873. 



\section{IN TRODUCTION.}

According to the views of the American geologists, the Devonian formation in the State of New York admits of subdivision into the following minor groups, in ascending order :-

I. Oriskany Sandstone. - This group consists essentially of coarse siliceous sand. tones and sands, sometimes more or less calcareous, sometimes argillaceous, and often containing nodules, layers and seams of chert. In its greatest development in the State of New York, the Oriskany Sandstone has a thickness of no more than thirty feet; and it is highly fossiliferous. According to Sir William Lngan (Gtolnay of Canula, p. 360,) the Oriskang Sandstone enters Canada at Waterlıo, on the Niagara River, and can be traced westward as far as the Township of Windham. It does not differ much from the Oriskany Sandstone of the State of New York in its litholorical characters, except that it is usually more highly cal careous, and in places is a grenuine though impure limestone. Its usual thickness is only about six feet, though sometimes attaining to as much as twenty-five feet; and it is often altogether wanting, when the Corniferous Limestone reposes directly upon the underlying Lower Helderberg formation.

The exact age of the Oriskany Sandstone cannot be siad to be altogether free from doubt. No mechanical break separates the Oriskany and Iower Helderberg deposits, and the difference which is observable in the f:aunas of the two groups is not greater than might be well accounted for by the litholorical change from the highly calcareous accumulations of the latter to the arenaceous sediments of the former periud. On the other hand, the ()riskany siandstone in the State of New York is sueceeded above by an almost uon-fossiliferous deposit, the so-called "Cauda-Galli Grit," which graduates insensibly into, and forms the greological base of, the fossiliferous "Schobarie Grit." Upon the whole, so far as the State of New York is concerned, there can be little hesitation in accepting the views of Professor James Hall, whowould regard the Oriskany Sandstone rather as the summit bed of the Silurian series than as the basement bed of the Devonian. Upon this subject, the above-named distinguished geologist thus expresses himself :- "Whatever may be the ultimate decision relative to the line of separation between the Silurian and Deronian systems, the base of the Schoharie Grit offers a much more decided limitation below, than does the Oriskany Sandstone. The new fiana bears less relistion to the preceding, and many of the new types are of a strikingly distinct character. In the Oriskany Sandstone, we have a considerable number of species which first appear in the Lower Helderberg Group; and the connection between these formations is much more intimate than between the Oriskany Sandstone and the Schoharie Grit."-(I'ulerontolum! of Lew Yorl, Vol. $1 V . p$. 3.)

With regard to the so-called "Oriskany Sandstone" of Canada, the case is somewhat. different. The abundant fauna which it contains is but slightly related to that of the subja. 
vent Silurians; but has, on the contrary, the very closest affinity with that of the Corniferous limestone above. Indeed, this is really understating the case ; since the fauna of the Oriskany Sandstone of Canada is, with very few exceptions, identical with that of the Corniferous limestone. All the typical and characteristic forms of life in the former pass up into the latter, and it is thus impossible to draw any palrontological line of separation between them. Nor, ayain, can it be said that there is any very close relationship between the fauna of the Oriskany sandstone of New York and that of the formation so-called in Canada. It is true, Mrr. Billings enumerates (Frolom? uf Cunulu, p. 360) amougst the nrganic remains of the latter, such cha-

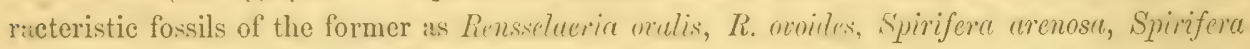
wrectu, and Urthis musrulese. As a more than sufficient set-off, however, against the resemblance thus established, is the fact that the Oriskany sandstone of Canada is crowded with the remains of corals, such as $F$. Gothlandica, $F$. hemispherica, F. turbinuta, F. polymompha, \&e., which are sharacteristic of the Corniferous limestone, whilst the Oriskany Sandstone of the State of New York appears to exhibit a total and singular absence of corals. The former deposit also contains numerous Trilobites and Brachiopods (such as Proetus crassimargimutus, Ilalmaniu selenurus, strophomenu inerpistriutu, s. perplunu, S. ampla, S. demisse, Chonctes hr-mispherim, Chonetes muerouatu, Athyris spirifernides, Centrondla gluns-fagea, Pentancrus fratus, de., which are not known to occur in the Oriskany Sandstone of the State of New York, but which are characteristic forms in the Corniferous limestone.

From a consideration of the above-mentioned facts, it seems evident, that, whatever may be thic true position of the Oriskany Sandstone of the State of New York, the formation which is so named in Canada clearly appertains to the Devonian system, of which it forms the natural base. The question, indeed, arises whether the deposit which has been identified in Canada with the Oriskany Sandstone may not rather be in reality the representative of the Schoharie Grit? On this question my own researches have been too slight to justify me in hazarding any positive opinion. In the descriptions which follow, however, I shall make no distinction between the Oriskany Sandstone of Canada and the Corniferous limestone, but shall regard the two deposits as palieontologically indivisible. No inconvenience can arise from the adoption of this course here, as I have myself detected no fossils in the so-called Oriskany Sandstone which I have not also recognised in the overlying ('orniferous limestone, and I have, therefore, to describe no forms of life as peculiar to the former deposit. I would only add, to prevent misconception, that I fully recognise the distinctness of the Oriskany Sandstone of New York as an independent formation, and that, so far as my own studies have led me, I deciredly lean to the view advocated by Hall, namely, that the Oriskany Sandstone should be properly regarded as belonging to the Silurian system and not to the Devonian.

II. Cadda-Galim Grit.-The Oriskany Sandstone, in the State of New York, is overlaid by a series of beds of arenaceous shale, argillaceous sandstone, or slaty grit, with a maximum thickness of sixty to seventy feet, and almost devoid of organic remains. These are known as the "Cauda-Galli Grit," from the presence in them of a peculiar spiral fossil supposed to be the remains of a sea-weed, and they have yielded as yet no other fossils excert the problematical bodies just alluded to, and a single specimen of a species of Platyceras. As before remarked, Prof. IIall is disposed to regard the Cauda-Galli Grit as the true base of the Devonian series of North America. No representative of the Cauda-Galli Grit has as yet been made out in the Devonian formation of Western Canada. 
III. Schoharie Grit. - The Cauda-Galli Grit graduates insen-ibly upwards into a finegrained calcareous sandstone, lithologically not unlike the Oriskany audstnne, and known as the "Schoharie Grit." This sandstone is only about four feet in thi.kness, and is richly fossiliferous. The organic remains are decidedly Devonian in th ir chiricter, snd some of the more typical species rass on into the overlying Corniferous lime tone without change. As examples of such may be mentioned strophomenu demisen, S. Chemungusis, and S. preplume.

No rejresentative of the Schohnrie Crrit has been detected ix Can da unless, as previously suggested, the sn-called Oriskany Sandstone of Western Ontario is truly the equivalent, in part if not altogether, of this formation.

IV. Upper Helnerberg or Colintenrous Limestonj:- - The essentially arenaceous deposits of the Cata-Crilli Grit and schoharie Grit are suruounted by the gromp of calcareous sediments, which mat be called "Upper Helderbere," from their development in the mountains of this name, or "('orniferous," from their usually having disceminated through them considerable quantities of siliceous matter iu the shaje of hornstone or chert (Latin wnu, horn). In the State of New York thene calcareous rediment are divided into two closely related groups, of which the lower has a thickuess of atout twenty feret, and is termed the "Onondagra Limestone;" whilst the upper is abont filty feet thick, and constitutes the " Corniferous Limestone" proper.

Even in the State of Ner York the distinction between the Onondagat and Corniferous Limestones is one of little moment; and in Canata no such separatiun can be made. In Western Ontario the limestones which represent the Onondaga and Corniferous limestones of New York, constitute a simele formation indivisible upon either palantological or lithological grounds, and to this the name of "Corniferous Limestome" has been senerally "lpplied by the Canadian geologists. The formation appeiers in Camada to have a thickness of abont one hundred and sixty feet, and it is estimated by Sir Willitw Isogth to cover an area of probably not less than six or seven thousand square miles. It is, however, for the most part deeply covered by drift, and is, therefore, but rarely exposed. Throughout almost its whole extent, it is richly fossiliferous, its organic remains consisting mainly and characteristically of corals, there being, however, also numerous Brachiopods, Gasteropods, Polyzoa, Sponges, Trilobites, and Crinoids.

V. Marcellus Shale.-This group consists of a series of black fissile shales, sometimes with subordinate layers of impure limestone, the whole having a thickness of from fifty to one hundred feet. No representative of this group, as distinct from the overlying shales of the Hamilton group, has as yet been satisfactorily determined in Canada.

VI.-Hamlton Group.-This group consists of a series of argillaceous, shaly, or flaggy beds, with thin courses of limestone, which raries in thickness, in the State of New York, from two hundred to as much as twelve hundred feet. In Canada. the Hamilton Group is well represented by argillaceous aud calcareous shiles with interculated beds of limestone, the whole having an estimated thickness of about three hundred feet. Though occupying a considerable area in Western Ontario, the Hamilton beds are seldom well exposed, and they are best exhibited in the Townships of Bosanquet and Plympton. They are charged with organic remains, consisting, for the most part, of corals, Brachiopods, and Pulyzoa.

VII. Tully Limestone. - In the eastern portion of the State of New York the strata of the Hamilton Group are surmounted by a dark-blue limestone, about twenty feet in thick- 
ness, which is known as the "Tully Limestone." This limestone thins out, in proceeding westward, before Lake Erie is reached, and it is not represented in Canada.

VIII. Geneser Slates.-Overlying the Tully Limestone, or in its absence the Hamilton Group, is a series of black, bituminous, sparsely fossiliferous shales, to which the New York geologists have applied the name of "Genesee Shales" or "Genesee Slates." Professor Hall unites these with the Portage Group, and their occurrence has not been satisfactorily recognized in Canada, unless they should be represented by the fissile shales of Kettle Point, Lake Huron, as has been gencrally supposed. In this case, the Genesee Shales of Canada are very important and interesting, from the presence in them of well-preserved remains of plants.

IX. Portage Group.-This group is composed of a considerable thiokness of shales, flags, and shaly sandstones. Few fossils are present, and the group is not known to be represented in Western Ontario.

X. Chenung Group.-If the Catskill sandstones and shales be regarded as belonging to the Carboniferous, the summit of the Devonian System in Eastern America is constituted by the so-called "Chemung Group." This consists of a great series of sandstones and shales, containing a considerable number of fossils; but no equivalent of the group has been recognized in Canada West.

The following table exhibits, in a summary form, and in ascending order, the varions members of. the Devonian Formation of the State of New York, with their equivalents in Ontario.

Devonian Strata of the Nitate of New York.

Equivalents in Ontario.

I. Oriskany Sandstone. Sandstones of North Cayuga and Oneida?

II. Cauda-Galli Grit No equivalent.

III. Schoharie Grit ...................... Sandstones of North Cayuga and Oneida?

Onondaga Limestone

IV. Corniferous Limestone $\}$ ( = Upper Helderberg Limestones)

V. Marcellus Shale

VI. Hamilton Shales

VII. Tully Limestone

VIII. Genesee Shales.

IX. Portage Group

X. Chemung Group
..Corniferous Limestone.

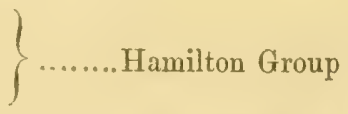

Fissile Shales of Kettle Point, Lake Huron, [with remains of plants. No equivalents. 


\section{CHAPTER I.}

\section{Protozoa of the Corniferods Limestone and Hamiton Formation.}

The remains of Protonna in the Corniferous Limestone, though not of a very varied nature are fitr from uncommon, and constitute quite a marked feature in the Lower Deronian fauna. ivith the exception of a species of Astreusponguic and one or two undetermined forms, they belong entirely to the enigmatical genus stromutoporu or to a genus so closely allied to this as to render any separation at present unadvisible. They may, with the greatest probability, be regarded as belonging to the spongidu; though the more typical forms of stromutmporm have not as yet been shown to possess some of the more important characters of sponge-structure.

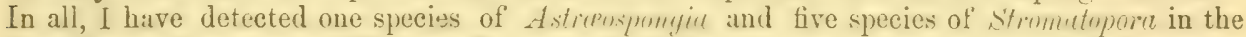
Corniferous Limestone of Western Ontario, all of the latter, with the exception of $S$. concent. rica (Gold.), being apparently new.

\section{Astraospongia, Sp.}

A single specimen has come under my notice of spicules which clearly belong to a species of Roener's genus Astirturymgiu. 'T'he spieules are hex-radiate, two of the radii being longer than the others, and each star havin a diameter of ahout one line measurine across from the extremities of opposite rays. Alone with the starlike rays are others of a simply aciculate form. Nothing but detached spicules have been obtained. and I have no knowledge of the general form of the Sponge.

Spicules imilar to those of the present species neeur not uncommonly in the IJamilton Shales of Cantudaigut, in the State of New York, and both have a cencral resemblance to

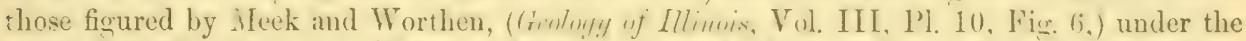
name of $A$. Immilfmensis. They are, however, more slender and delieate in their proportions. It is quite probable that our form is distinct; but, having merely such framentary remains of it. I have uot thought it advisable to describe it under a separatespecific title. I similar, if not identical, form has also been deseribed by Romer from the T pper Silurian of 'Teunessee, (Sil. Fauna, West Tenn., p. 14.)

Loculity and. Finmulon - From the base of the C'orniferous Limestone (()riskany Sand stone ?) near Port Colborne.

\section{Genus Stromatopora (De Blainville).}

The genus simmetumma includes a number of fossils of doubtful affinities, which have the common character of forming amorphous mases or extended sheets and crusts composed of

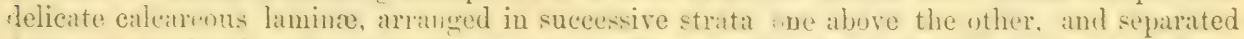
from one another by minute vertical props or pillars, which sone bulieve to be tubular. Very of teu, the succesive lanina are disposed round an imaginary centre or centres in a concentric matuer. giviug rise to spherical, hemicpherical, or irre_ular forms. In other cases, the mass is extended so as to form an expanded cup or irregular sleet, composed, like the preceding, of succesively superimposed laminæ.

The main element, therefore, in the structure of Stromatopora, and the only one as to which all observer's aplyear agreed. is a system of parallel calcareous limina generilly of great tenuity. not in actual contict, but separated from one another by narrow interspaces. The succes-ive lamina are kept apart by a system of calcarenus rois. or pillars, which are directed at risint angles to the lamima, and divide the intervals between the latter into minute quar. rangular compartments.

So fir, the structure of Stromutrunra would be compatible with a reference of the genus nither to the For uminiferie or to the spongule; but there are unfortumately many differences 
of opinion as to the further details of the structure of Stromatopora, and these have led to equally wide differences of opinion as to the affinities and systematic place of the genus.

According to McCoy (I'ul. Fo:s., p. 12,) the vesicular tissue of Stromutopor is composed of " minute curred calcareous plates," which he compares with the coenenchyma of Pulerupore and $F^{\prime}$ istulizort. He also states that the upper surface is occasionally marked "with extremely obscure, distant, quincuncially arranged, small pits," which he appears to think may represent the corallites in the above-mentioned and other allied genera.

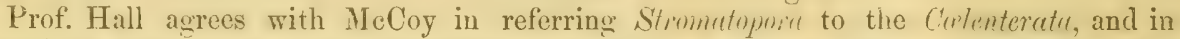
placing it in the neighbourhood of Tulipure (Pul. N. Y., Vol. II. 13. 135.).) He considers that the forsils of this genus are composed of "minute eylindrical tubes with considerable space between; and that the laminated structure arises from thin layers of calcareous matter de. posited and filling the spaces between, and enclosing the tubes."

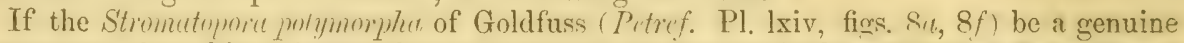
Stromatopuru, then this eninent palæontologist long since recognised the fiact that stromatopor, is a genus of Sponges. There is, however. some doubt on this point; since neither his description, thomgh unusually precise, uor his figures demonstrate the existence in this species of the minute structure peculiar to S/romertommen. Nor is this point cleared up satisfactorily by the description given by McC'oy of this same species ( $P a l$. Frs. p. 65); whilst D'Orbigny

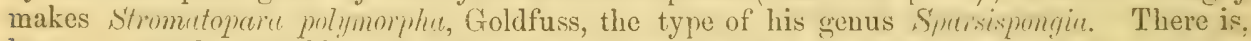
howerer, much resemblance between $\$$. pulymiryllu and some of the species of Stromatopora from the Devonian Rocks of Ontario, especially S. granulata, Nich.

My own iuvestigations of a very extensive series of exilmples from the Lower and Upper Silurian formations, and from the Devonian Rocks, have led me to the opiuion that the genus Strometopora is elearly referrible to the Symmidu, and that it should be placed amonest the Calcispongia, a group represented by many and varied forms both in past time and at the present day. The reasons for this belief may be summed up as follows:-

a. The fundamental structure of sitromatopor is by no means inconsistent with the belief that it belongs to the Culcispunuice. It does not consist of reticulated calcareous spicula, as in the more typical members of the group; but neither roes it consist of a vesicular tissue composed of "minute curved caleareous plates" (McCoy', which could be in any way compared with the vesicular conenchyma of many tabulate corals. Ou the contrary, it consists of successive calcareous layers, which may be regarded as composed of an amalgamated system of horizontal spicules, separated by intervals, and kept apart by a vertical system of delicate calcareous props or rods, giving rise to a system of more or less quadrangular eells. The horizontal laminæe are upon the whole continuous, but they sometimes sub-divide and inusculate; and the vertical pillars are decidedly irregular, being sometimes inclined at various angles, and not being placed at uniform distances in all parts of even the same specimen. Some of the rertical rods pass continuously through several lawina and the interspaces between them; but the greater number are eonfined entirely to the interval between two successive lamina, and are not continuous, nor correspond with those in the interval immediately above or below. There is no ground, so far as $I$ am aware, for the supposition that these vertical pillars are perforated, or are of the nature of tubes inhabited by the separate zoôids of a colony ; indeer in the forms which occur in the Corniferous limestone thare is the strongest positive proof that this is not the case, and that they are of the nature of solid rods or dissepiments. There is nothing in the fundamental tissue or groundwork of Stromatopora, as above described, which would necessarily preclude us from referring the genus to the Symgida; nor can any stress be laid upon MIeCoy's argument that these organisms cannot be sponges on account of their possessing a rigid and inflexible skeletın, since similar reasoning would compel us to remove from the spengilla a vast number of forms the zoological position of which is beyond doubt. At the same time, if stromutoporc consisted wholly of the laminated and reticulated tissue just described, and possessed none of those openings which are so eharacteristic of the sponges, then, indeed, the genus might be more properly referred to the Foraminifera, in many respects the close allies of the sponges, but destitute of the canal-system which is present in the latter.

b. Such openings, however, can be shown to exist in certain forms of Stroncloporc, and there is strong reason for believing that they will ultimately be found to be present in all. Thus in Strometoporice strintelle (D'Orb.), and s. concentrica (Gold.), both typical examples of the genus, Professor McCoy long ago described the existence of vermicular tubes opening 
on the surface by small apertures, and passing more or less vertically through the component

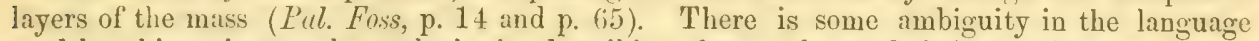
used by this eminent palæontologist in describing these tubes and their openings in $S$. concentrica; and the evidence is not at present sufficient to warrant any positive statement of opinion as to whether they mily correspond with the "pores" or the "oscula" of an ordinary sponge. It is probable, however, that they should be regarded as representing the "pores," and that the "oscula" will yet be discovered by a more extended and careful examination. Again, in S. ostioluta, (Nich.), a species from the Guelph formation of Canada, the upper surface of the mass carries small but regularly arranged openings, which can hardly be regarded as being other than "oscula" (Ammuls of Nuturul History, Aug., 1873, p. 90, Pl. 4. fig. 1). In s'. tuberculata (Nich.), again, I have now discovered a system of comparatively large, though remote, openings which communicate with canals traversing the organism, and which appear to fulfil beyond all question the function of exhalant apertures. 'Undoubted oscula also occur in S. grumulata. Lastly, in the S. perforatu (Nich.), now deseribed for the first. time, the entire mass is perforated by numerous and close-set canals, of considerable size, opening at the surface in rounded apertures and generally at the summit of chimney-like or conieal eminences. These opeuings must represent "oscula." It is true that in few instance: with which I am acquainted has anj species of Stromutopora been shown with certainty to possess two sets of apertures, small and large, one set being inhalant and the other exhalant. It must be remenbered, however, that thedifficulties of observation in this cave are very great : and the "pores" might have escaped notice either from their minute size, or from the condition of mineralisation in which these fosils necur, all the carities of the mass being filled up with foreign matter, and the reticulated tissue itself being often silicified. Or, it is possible that in some of these ancient forms the two sets of apertures were of equal size, and are thus incapable of being distinguished in a fossil condition. Still there are some eases in which fossils in other respectis refirable to stromatopora have been shown to jinssess both iuhalant and exhalant apertures. The e:ses in question are S. gromlute (Nich.). in a sinele specimen only; St. lululatir (Nich.) at still undescribed species from the Niarara limestone of Indiana, and s. Mindei (Nich.). from the Niagara limestone of Canada. Of this last natmed species, I append an engraving in which these two sets of apertures are well exhibited.
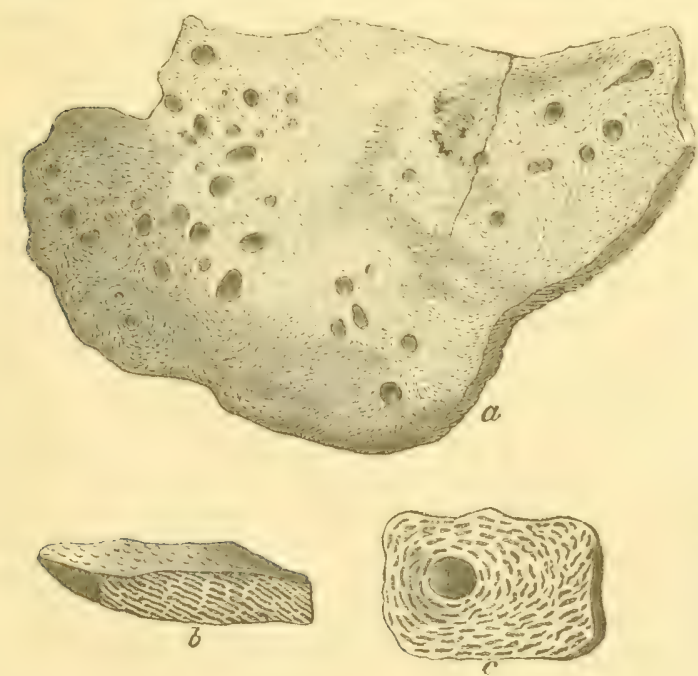

Fig. 1.-Stromatopora Hindei (Nich.), a, upper surfsce of a fragment, of the natural size; $b$, vertical section, enlarged; c, upper surface of a fragment, enlargedNiagara limestone. have commenced its existence in the
Lower Silurian and to have died out in the Carboniferons period. In the Deronian periou the genus would seem to have attained its maximum; and I have to record no less than five c. 'The shape of the various species of Stromatopora is such as would accord perfectly well with the belief that that they are Sponges. Some are in the form of rounded or irregularly hemispherical or conical masses. Others are somwhat cup-shaped; and others, again, have the form of irregular and extended crusts, apparently attached at one point to some solid body, from which they spread laterally in every direction.

Upon the whole I think the evidence is very decidedly in favour of the view that the genus Stromatopore is referable to the Calcispongice. In accordance with this view, I shall retain in this genus the forms here described as $S$. tuberculata and $S$. perforata; since these, at any rate, appear to be unquestionably sponges, and they would, upon any other view of the affinities of Stromatopora, require a new genus to be formed for their reception.

The genus Stromutoporc appears tn 
species from the Corniferous Limestone of Ontario. One of these, viz., S. concentrica (Gold.): is a well known European species; but, owing to its mode of occurrence and state of preserva. tion, I regard its identification as, to say the least of it, doubtful. The other four species are new.

\section{Stromatopora tuberculata (Nicholson).}

(Plate I., figs. 2 and 3.)

Strometepere tulerenlate.-Nicholson. Annals and Magazine of Natural History, August 1873. Plate IV., figs. 2 and 3.

Fossil forming crusts or irregular expansions of varying thickness, and often covering large surfices, composed of numerous concentric calcareous laminæ, separated by delicate ealcareous rods, pillars, or dissepiments, which are disposed at right angrles to the lamina and mark off minute cellular compartments or interspaces. The laminæ and intervening space: are about five in the space of one line, sometimes four; and the vertical pillars or dissepiments are comparatively strong and placed at proportionately remote intervals. The upper surface of the mass is more or less strongly undulated, and is covered with closeset, covical, clavate or fungiform tubercles, the elevation of which is about from one-fiftieth to one-twenty-fifth of an inch above the general surface. The tubercles would seem to be sometimes perforated, but are more commonly imperforate, and they are placed in irregular sinuous lines, three or four sometimes coalescing longitudinally. They are separated from one another by about their own width (more or less), about one-twenty-fifth of an inch. When the fossil is broken, it is seen that similar tuberculated surfaces occur at various depths ie the mass, concentric with one another, and separated by laminated and reticulated tissue.

The under surface is covered with a thin calcareous basement-layer, which is thrown inte very numerous, concentrically-arranged, undulating wrinkles. This surface is not unlike the epitheca of a Farosites, but is not so smooth, and does not appear to have been absolutely unbroken.

Both upon the upper surface and the lower are placed at irregular intervals rounded apertures from half to two-thirds of a line in diameter. They appear to be wanting in some specimens, which. however, are fragmentary; whilst they can be readily detected in others. They are the openings of canals which penetrate the mass in a more or less vertical direction, and they can hardly correspond with anything except the oscula of sponges. The distance of these apertures apart varies from two lines to half an inch.

As regards one of the most important points in the structure of $S$. tubercuiutu. namely the large canals and exhalant orifices, I have now obtained fine specimens which set the question at rest. In my original description (Loc. cit. p. 93), I stated the case as follows: "Many examples exhibit rounded openings or tubes, from half a line to a line in dimmeter. descending at right angles to the mass, and placed at varying intervals. These openings are not elevated above the general surface. They are not constant in their occurrence, though very generally present; and I have not been able to satisfy myself that they are not truly extraneous to the fossil. They may, perhaps, be annelidous in their nature; or they may be due to the fact that the organism has enveloped a colony of Syringopora, which has subsequently been dissolved nway." The specimens now in my possession, however. prove conclusively that these canals and apertures are truly parts of the fossil, and they appear to be strictly comparable to the oscula of sponges. They are mostly to be detected upon the upper surface, but in one large specimen which seems to have grown from a broad base of attachment, and then to have spread out laterally in an irregularly cup-shaped form, they are plentifully developed on the lower surface. There is thus every reason for concluding that $s$. tuberculuta is truly a calcareous sponge; and the chief question remaining is, whether it can with propriety be retained in the genus Stromatopora. My own opinion is against forming is new genus for its reception, since it has the essential structure of Stromatopora, and the difficulty which I experienced at first in detecting the oseula in examining even a large series of specimens, has convinced me that the occurrence of similar openings may well have been orerlooked even in the type-species of this genus.

Sitomutripure tuluerculate is readily distinguished by its very coarse reticulation, the tuberculated nature of the upper surface, the concentrically-wrinkled under-side, and the presence of remote and irregularly placed oscula, which are not situated upon eminenees. Whether the 

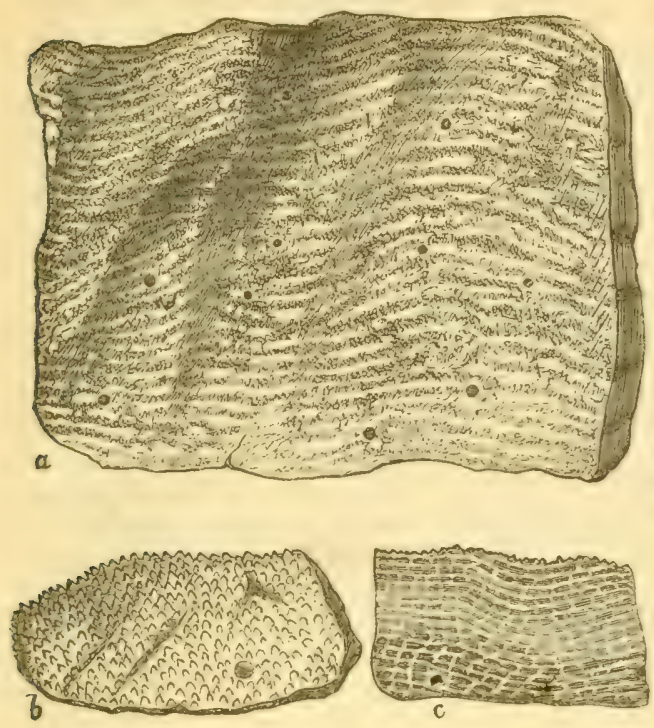

Fig. 2. $-a$. Part of the under surface of a large specimen of Stromatopora tuberculata, showing the wrinkled basement layer, and the openings of the oscula, natural size ; $b$. a portion of the upper surface, natural size; $c$. a vertical section of a fragment of the same magnified to show the internal structure. small surface tubercles are perforated or not. remains an open question, but I should be disposed to think that some of them, at any rate, were so, thus corresponding with "pores." The crusts or expansions of this species often. cover large surfaces; but it is certain that in many cases a great portion of the under surface must have been free and unattached to any foreign body. The general thickness of the crusts varies from three to four lines to two inches or more; but the latter specimens are to be regarded as being composed of a succession of crusts superimposed, the younger upon the older, as is shown by the occurrence of tuberculated surfaces at various levels througbout the mass.

Locality and formation.-Common, in a silicified condition, in the Corniferous limestone of Ridgeway and Port Colborne.

\section{Stromatopora perforata (Nicholson).} 1874.

Nirmmatopore priforete (Nicholson.) Annals and Magrazine of Natural History. Jan..

Fossil composed of crusts of varying thickness, made up ot thin concentrically arranger calcareous lamine, the inter-paces between which are rendered vesicular by vertically disposed calcarcous rods or disepiments. From four to five lamina with their intervening intersfaces, in a line. Upper surfice undulating. and covered with very numerous rounded apertures, which vary in wilth from two-thirds of a line to one line, and are placed at distances apart of a line, more or less These apertures are usually placed on the summit or at one side of conical eminences. or they are elevated above the general surface, the lip of the opening on one side being fenerally higher than on the other. These apertures are the orifices of more or less rertical or somewhat oblique eanals which penetrate the reticulated structure of the mass, and are lined by a delicate calcareous membrane marked with faint encircling strix. Each canal descends at first and for a certain distance (about three lines) in a straight line, and then is curved so as to become nearly parallel to the lower surface of the mask, at the same time contracting in its diameter. Between the oscula, as just described, the surface is covered with a fine miliary granulation. composed of minute pustules, placed close together, and arranged in irregular vermicular and sinuous lines.

Stiomertipora pufinutu is, perhaps, the most remarkable species of the genus which has been as yet discovered; and it can not be doubted that it is a genuive member of the Calcispontere, though iu some-respects an abnormal one. In its internal structure it agrees altogether with S. tuberulata, S. gramulatu, and $s$ mammillute; and with the two former of these it agrees further in the possession of a series of apertures which eannot be anything but "oscula." No "pores," however. have been detected, unless some of the surfuce-tubercles should in re:lity be perforated, which is likely enough.

s. porforuta is readily distinguished from $S$ tuherculuta by the much greater number and closer arrangement of the osculat, by the elevation of these apertures above the general surface. and by the finer granulation: of the upper surface. The number and closeness of the oseula 

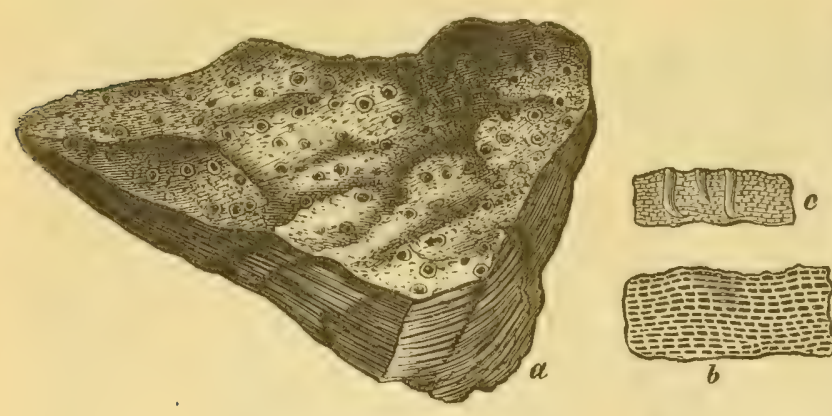

Fig. 3. - $a$. A fragment of Stromatopora perforata, showing the osculiferous upper surface, natural size; $b$. fragment of the same, magnified to show the internal structure; $c$. vertical section, showing the form and course of the canals. also separate this form from $S$. granulata, in which the oscula are remote, and can often not be detected at all, though in other respects the surfacecharaeters of the two species are identical. The under surface of $S$. perforata is still unknown; but the fossil forms thinner or thicker crusts, often covering pretty extensive surfaces; the thicker expansions being composed of a succession of crusts superimposed one upon the other.

Loculity and Formution.Rare in the Corniferous limestone of Port Colborne.

\section{Stromatopora granulata (Nicholson).}

Plate I., Figs. 3 and $3 \alpha$.

Stromutmone momulinte. (Nicholson). Annals and Magazine of Natural History, August, 1873, Plate IV., Figs, 3 and $3 a$.

Fossil forming thin crusts, or horizontally-spreading expansions (usually about a quarter of an inch in thickness, but ranging from one line up to half an inch), often occupying extensive surfaces. Crust composed of concentric calcareous lamina, from six to ten in the space of one line, separated by interspaces which are minutely broken up into cells by numerous delicate vertical rods. Upper surface regularly undulating, often raised into chimney-like (r conical elevations, which are for the most part destitute of any appearance of being perforated, but which are sometimes pierced by distinct rounded apertures or "oscula." The entire sur. face is covered with a fine miliary granulation, constituted by minute conical pustules, placed close together, often confluent and arranged in sinuous lines, and apparently implerforate. One example, however, shows that this granulated layer is not the true surface, but that it was covered in the perfect organism by an exceedingly delicate calcareous membrane, perforateri with minute apertures or "pores." Exfoliated and broken specimens show that similar gratnulated surfaces oceur at small intervals all through the mass. The under surface (in some cases at any rate, is supported upon a coneantrically-wrinkled calcaresus basis, precisely similar to the epitheca of a Favosites or a Fistulixora.

The specimens upon which I founded my original description (Lor. cit. p. 94) did not exhibit some of the most important of the points comprised in the foregoing specific diagnosis. In unne of the examples which at first came under my uolice, wits 1 able to detect either useula or pores. In a framment, however, of this species, which I discovered in the Hamilton formation of Widder. I have now succeeded in detecting both these struetures; and I have oltained additionil eximples from the Corniferous formation, showing the under surface and also the mode of growth.

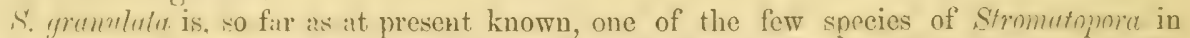
which two sets of apertures exist, one large and exhalant, the other small and inhalant. In the specimen from the Hamilton shales in which these apertures can be detected, the osculat have the form of comparatively larece openings, of a circular or oval shape, placed at the summit of distinct rounded or conical elevations. The pores, on the other hatud, are only obwervable in a portion of the specimen, and are seen to have the form of minute elose-set perfor:tions in a delicate calcareous membrane or layer. Beneath this layer, and over all parts of the fossil where it his been denuded, is seen the ordinary gramulated surface from which the uame of the species was originally derived. There is thus a strom probability established that all the specimens from the Corniferous limestone, which cxhibit simply this granulated surface are imperfect, and that there has been removed from them an exterior and very deli- 
cate layer in which the pores were perforated. The granulated layer which appears to form the surface in so many specimens, would thus appear to have been covered by a kind of " dermal" membrane, and to have permitted a tree circulation of water over its surface, the granules being more or less confluent, and giving rise to a complicated system of sinuous or vermicular horizontal channels.

In a great many specimens the surface layers exfoliate round numerous points, giving the upper surface of the fossil quite a characteristic appearance, which is wanting in $S$. tuburculatu. Genurally speaking, S. "rranulutu may be distinguished from S. tubereulatu, to which it is nearly :llied, by the more delicate charucter of its reticulated tissue, and by the fact that the minute crowded tubercles which cover the surface are so closely placed as to be nearly in contact. As a rule the species oecurs in the form of very extensive undulating crusts, one specimen observed by me covering a slab about three feet in length, by two feet in width. with an average thickness of hall" an inch. I possest, however, one eximple, in which the organism is attached by a broad base to a large HFlinjly/lum, from which it ripeals out laterally in all directions as a horizontal expansirm. the under surface being enveren with a wrinkled "epitheca," and having obviously been free.

Lorratity anul formution.- Not uncommon in a silicified condition in the Cornfferons limestone of Ridereway, Port Colborne, and Savage's luarry, fianflect, also rare in the flamilton formation of Bosanquet, at Bartlett's Mills, near Arkona.

\section{Stromatopora mammilata (Nicholson).}

$$
\text { (Plate I., Fig. 4.) }
$$

Stromutopon mammillutu (Nicholson), Annals and Magazine of Natural History, Aug., 1873. Plate IV., Fig. 4.

Fossil forming thin crusts, about two or three lines in thicknes, often covering extensive surfaces. Crust composed of successive concentric calcareous limina, separated by interspaces, and broken up by vertical dissepiments. Surface unlulating and exhibiting a series of large conical elevations about one-fifth of an inch in height and the same in diameter at the base. placed at distances apart varying from one fifth of an inch to half an inch. Most of these conical elevations show no signs of being perforated; but -one appear to lave apertures at their summits. The surfaces between these elevations, as well as the elevations themselves, are roumhened with numerous small granules, tubercles and irrerular, sinuous ridges.

Nothing could be more distinct than the aspect of this very remurkable species, the large conical elevations which cover its surfice giving it exactly the appearauce of an undulating plain covered with small volcanoes. Superficially examined, it presents a striking resemblance to many recent sponges; but it cannot be asserted lositirely that the conical elevations just alluded to are really of the nature of oscula. Some of them certainly look as if they were perforated ; but most show no signs of any aperture. This. liowever, is very probably due to the manner in which the fossil has been preserved; and the analowy of st. arcumlutu would lead one to conclude that the conical elerations of $s$. mmmmillotu are truly oscula. The internal structure of all the examples which I possess of this species is much more imperfectly preserved than is the ease with the other species here described; and I have simply been able: to satisfy myself that it is essentially the same as is characteristic of stmmutnmme in general. I have seen crusts of this species covering an area of several square feet: but it is by no means common in its occurrence.

Lurulity und Formution. - Rare, in a silicified condition, in the Corniferous limestone of Port Colborne.

\section{Stromatopora concentrica (Goldfuss).}

In addition to the previously described species, there oceur in the Corniferous limestone of Western Onturio specimens which are hardly or not at all distinguishable from Stromatopore concentrica (Goldfuss). As, however, all of these specimens are fragmentary, and none of them exhibit their surface, it can not be positively asserted that they belong to this familiar Devonian species.

Locality and Formation.-Corniferous Limestone, Port Colborne. 


\section{CHAPTER II.}

\section{Corals of the Corniferous and Hamilton Formations.}

Of all the organic remains of the Devonian Rocks of Canada, and especially of the Corniferous Limestone, none are more conspicuous than the Corals, whether we take into consideration the vast number of in lividuals or the great variety of type which they exhibit. Many parts of the Corniferous Limestone are almost wholly made up of enrals ; and as these are usually silicified, thcy weather out of the livestone in a most beautiful manner, and can be obtaincd in a state of exquisite preservation. The soft shales of the Hamilton group, also, are often charred with the remains of corals, which, from the decomposition of the surr unding matrix, can be obtained perfectly clear of adhering sediment. Mr. Billings in his admir-

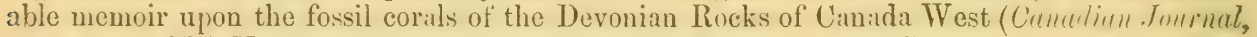
Nere serice, Vol. V., p. 2.51), estimates the number of corals in the Corniferous and Hamilton formations as probably about eighty, and of these he describes no less than fifty-four. Some of the most striking of these forms, such as the species of Plitlipsestreca, have nut enme under my notice in any portion of the ('orniferous Limestone or Hamilton Group studied by me; but I shall here describe over seventy s' ecies which have enme under my personal observation. Of these, thirty-one belong to the Timbilutu, five are referible to the T'ulumben, and thirty-five be!ong to the great group of the linfusi. 'The gencrat represented are twenty-one in number,

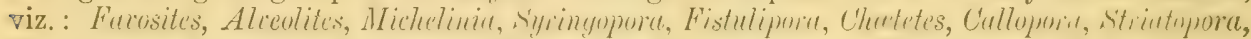

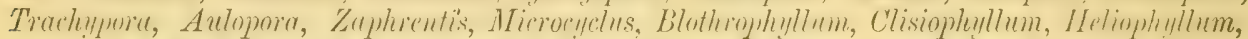

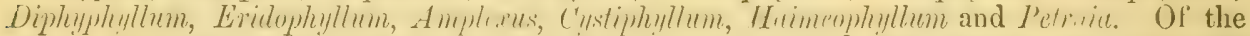
species about twelve can certainly be identified with known European species, viz.: Finsites

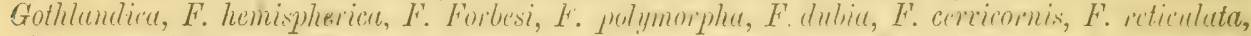

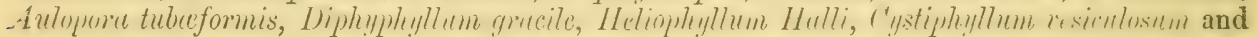
Michelinin comera. Besides these well known forms, there are others which are very closely allied to Wuropean species, and some which may perhaps turn out, upon fuller inrestigation, to be nothing more than varieties.

\section{Genus Blothrophyldum (Billings).}

Gen. Char._- Corallum simple, turbinate or cylindrical. Internal structure cmsisting of a central area occupied by flat transverse diaphragms, an intermediate area with strong radiating septa, and an outer area in which there is a set of imperfect diaphragms projecting upwards, aud bearing on their upper surfices rudimentary ratiating septil. A thin complete epitheca, and a septal fossette" (Billings).

The central space of the theca in enrals of this grenus is necupied, as in Amplerms, hy fit or slightly flexuoustabule, upon which the septa do not encroach. Outside this central areat isan narrow zone in which the tabulae are bent downwards towarls the base of the curallum, and are at the sime time sometimes. split and bifurcated, whilst the continuity of the spaces letween them is interfered with by a series of strong repta. Uutside this again is an outer zone, formed by a series of tabula, which aye directed upwards and outwards in an arching manuer, and which carry on their upper surfaces a series of imperfect septa, their lower surfice being simply costate or ridged. Lastly, the arehed tabula of this external zone are covereal by a thin but strong epitheca with which the outer surface of the coril is invested. 'The genus differs from Zuplirentis in not having the septa prolonged inwards to, or near to, the centre, and in having the eentral tabulate area surrounded by a partially vesicular zone and an exterior zone composed of arched tibula and imperfect septa. From Amplerus it is distingui-hed by the possession of the exterual area last mentioned, and by the septa being more lin; - ely developed; whilst it is distinguished from ('/isionhlly/lum by the first of the abovementioned peculiarities, and also by the fact that the tabulie of the central area are flat or slightly flexuous, and are not elevated into a conical protuberance.

The genus Bhothroplenllumi was originally defined by Mr. Billings (Cun. Jomi. New Series, vol. iv., p. 12!9) and the single species Bs. decriticatum was described. In addition to this previously recorded and very characteristic species, I have now to describe annther allied form, B. upprocimutum, also from the Corniferous Limestone of Western Ontario. 


\title{
7. Blothrophyllum decorticatum (Billings).
}

\author{
(Plate IV., Fig. 3.)
}

Fig. 25.

Blothrin)luyllum decorticutum (Billings) : Cunadian.Journal, New Series, Vol. IV., p. 130,

"Adult specimens, two feet in length, and three inches in diameter; dimensions of the immature individuals, variable; usually slender and irregularly cuired; outer area consisting of rather strong rudimentary transverse diaphrioms, curving upwards and outwards, distant from two to eight lines, betring upon their upper surfices imperfect radiating septa, which do not exteml from one diaphragm to another. "Thes. sepita are half a line distant at the margin of a specimen three inches in diameter. When the epitheca is preserved, the surfice of this species is marked by numerous deep anuulations and sharp encireling folds, their edges being always on the upper side. The transverse diaphragms in the central area are nearly flat, but have a strong septal fossette upon one side" (Billings).

In the examples which I am disposed to refer to this slecies, the arched tabula of the outer area are not less than two lines apart, often from a quarter to half an inch, and the tabulo of the central area are also distant. The central tabule are often quite flexuous, but are never elevated into a boss; most usually they are neirly flut. The septa which spring from the upper surface of the arched tabulit of the outer area only reach the tabula immediatcly above in the inner portion of the area in question; but in the outer portion of tire same area fall furshort of the tabnle above, owing to the fact that the tabula are stronsly arehed, and have their concavities direeted towards the base of the coral. The concave under surfaces of the tabula of the external area present, however, well-marked ridges corresponding with the septa on the upver surface. 'The septa on the upher surfices of the tabulie vary from half a liue to a line in distance from one another, but there are very enerally intercalated between the larger - epta smaller ones, one between each pair. which have simply the form of slightly elevated rideses. The epitheea is not only marked with encireline annulations and folds of growth, but also with distinet Inngitulinal enroves, five in the spatee of two lines. The epitheea, however, is rarely preserved, and specimens oceur mont comm nly in one or other of two conditions. Fither the epitheea bas been remored, exposing to view the arched tabula of the outer area with the imperfect septat on their upper surfices ; or the entire outer area has been removed alone with the epithecal, leaving the central and intermediate areas in the form of a core to the outide of which are attiched the bises of the arched tabula of the outer area. This gives rise to an appearawee which is excedingly characterictic of the present species, and by which it can almost be infillibly reengnized even in very imperfect examples.

Locality and Formutim.-C'nmmon in the Corniferous Limestone of Purt Colborne, Riltervay, Hagersville, and at many other points where the formation is exposed.

\section{S. Blotmrophyllum approximatum (Nicholson).}

$$
\text { (Plate IV., Hig. 2.) }
$$

Bluthroplytlum approrimulum (Nicholson), "Canadian Naturalist," Vol. VII., No. 3. 1 s73.

Corallum of unknown length, eylindrical. The outer area consisting of strong arched diaphragms, curving upwards aud outwerds, distant from one another from half a line to two lines, bearing upon their upler surfice imperfect septa which extend from one tabula to another when the tabulie are remote by the former distance only, but which do not do so otherwise. Septa alternately larere and small, distant about a third of a line. Tabula of the central area closely approximated, from three to four in the space of two lines, flat or slizhtly flexuous, the septa ouly slightly encroachius upou them. Epitheca with numerous constrictions of growth and encireling annulations. and obscure longitudinal strix. Dimensions unknown, but certainly attaining a diameter of three inches.

In most of its essential characters this specias anress with Binthropleyllum derorticutum, (Billings, ) of which perhaps it is merely a variety. It is, however, distinguished by its crenerally much greater size and by the apparently consiant peculiarity thit the taliulae of the outer area are very closely set, much more closely than in B. decorticutum. Thus tynical 
specimens of the latter exhibit only from three to five of the curved tabula of the outer area in the space of an inch; whereas examples of $B$. approximutum present no less than from ten to fourteen tabula in the same space. Whether this character is one of specific value or not, may be questioned; but I think it advisable to refer provisionally the specimens which exhibit it, to a new species.

\section{Locality and Formation.-Corniferous Limestone of Port Colborne.}

\section{Genus Clisiophyludi (Dana).}

The genus Clisiophyllum is in an unsatisfactory condition, different palreontologists having included under this head Cyathophylloid corals which exhibit considerable differences in structure. This will be evident, if we compare together the definitions of the genus given by three distinguished authorities. Milne Edwarrls and Jules Hinime define the genus as follows: "Corallum simple, turbinate. Sepin well developed, and rising towards the centre of the calice su as to form a spurious columella, but not twisted."

Prof. MeCoy defines C'Tisioplufllum as follows: "Corallum simple, branched or aggregate, with vertical radiating lamellox: a thin epitheca or outer will; interuel structure-(vertical section), central area composed of small vesicular plates and cells converging or arcling u outer area of small cellular structure, inclining in the opposite direction or uprards and outwirds, separation between these areas formed by an intermediate area of larger, nearly horizontal, cellular structure; (horizontal section) a large central area of small irregular cellular texture, from which the primary lamelle radiate to the outer walls, intermediate zone with few vesicular plates between the lamellæ; outer zone having the primary and secondury lumellæe connected by very numerous vesicular plates."

According to IIr Billings, lastly, the corals of the genus Clisiophlyllum "have the same general external form as those of the genus Zaphrentis, and their internal structure is also the same, except that the transverse dial,hragms are elevated in the centre so as to form a small conical protuberince in the bottom of the cup, and, further, they are enveloped in au outer area composed of vesicular tissue. The septal fossette is smill, and in worn specimens its place is often indicated by the prominence of one of the septa on the outside, which, being stronger than the others, forms a longitudinal angular ridge. The cells of the tissue which fills the nuter area, slope upwards and outwards."

It will thus be seen that high authorities differ widely as to the structure of the corals which compose the geuus Clisioplhyllum. The most promineut distinguishing character of thegenus is admitted to be the presence of a conical boss or projection at the bottom of the calice; but there are grave discrepancies of statement as to the muner in which this projection is formed. According to Milne Ldwards and IIame the boss is formed by the rising of the septa of the coral towards the centre so as to constitute a spurious lamellar columellathe tilbule being comparatively poorly deveinped, and the genus being thus widely removed from Zayplecutis. According to McCoy, ayain, there are no central tabula, in the proper sense of the term, and the central projection is former by the elevation and convergence of the cells of a central vesicular area-this also removing the genus widely from Zuphrientis. Latitly, MIr. Billing considers that the central boss is formerl by the elevation of a series of well-developed tabula; and he places the genus in the immediate neighbourhood of Zupluicntis, or considers, at any rate, that the two genera are very closely allied.

The above discrepancies are so great that it reems probible that several forms, in reality belonging to different genera have been relerred to C'isioflyllum. Without, however, pretendiug to decide this point, I shall simply dexcribe here the previously recorded Clisiophullum O...ilinese (Billings), from the Corniferous Limestone of Ontirio, together with a related but undescribed form, merely remarking that neither appear's referable to the genus Clisionhyllun as defined by $\mathrm{McCoy}$.

\section{Clisiophyluum Onemdense (Billings).}

\section{(Plate IV. Figs. 4, 5).}

Clisimphyllum Oneidaense (Billings), Canutian Jourual, New Series, Vol, iv, p. 128.

Corallum simple, turbinate, cylindrical or cylindro-conic, often curved. Central area oc spied by strong transverse diaphrayms or tabula, which are more or less strongly elevated 
so as to form a central boss or projection. Radiating septa numerous (from eighty to on ${ }^{e}$ hundred), varying much in the extent to which they encroach upon the central tabulite area. External area thin, vesicular, its cells formed on the one hand by the septa, and on the other by a series of curved plates, which extend in an archiug manner and in a direction nearly parallel with the axis of the goral, obliquely from the central area to the epitheca. When the epitheca is removed, the apertures of the cells of this external area appear on the surface in the form of rectangular openings directer very obliquely inwards. In specimens in which the epitheca is preserved, the surface exhibits encircling ridges and annulations of growth, varying much in their comparative remoteness, snmetimes rounded, snmetimes sharp-edged. There are also numerous coste, varying from four to six in a space of two lines in specimeus of different sizes. A well-marked septal fossette can usually be detected.

As already remarked, the internal structure of this species dies not conform with the definition of Clisinghyllum wiven either by Lidwards and Haime or NeCoy ; and it seems doultful if it can be retained in this genus. In most resrects the species ermes nearest to the ohatauters of Amplerus, but it is distinguished by the presence of a cone and the possession of an extermal resicular area. The cone or centwal buss is certainly formed hy an elevation of the tabule of the central area, and the condition of the septia varies very much in different examples which appear to be otherwice reforeble to this species. Sometimes the septa extend as far as the centre of the coral, being continued across the upper surfaces of the tabula in a diminished and rudimentary form. Suchex mples would, perhaps, come under the definition of Clivinglyllwm given by Hilne Edwards and Haime. Iore enmmonly, the septa are comparatively rudimentary, and extend but a short distance from the outer wall, leaving the central tabula exposed, very much as occurs in Amplexus.

Hxamples of this species from which the epitheea has been remored, ma us ally be determiner by the peculiar rectangular and obliquely-descending cells of the outer re-icular area. It must be admitted, lowever, that if the internal structure is not shown it is some.

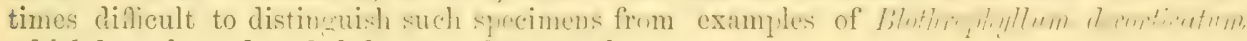
which have been denuded down to the central core.

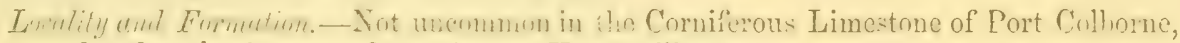
and very abundant in the same formation at Hagersville.

\section{Clistophyllum Plumimadile (Nicholson).}

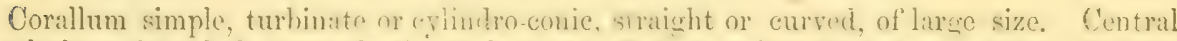

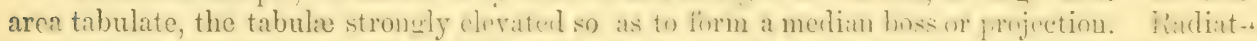
ing septa excedingly numerous, altemately larese and small, being about one lianthed and twenty in specimens of an inch and a lalf in diameter, and rising to one hundred and eighty in a specimen two inches and a quarter across. The septa extend a considerable distance inwards, and a septal fossette is present. Surfice marked with numerous romider encireling folds and annulations, and also with strong and unusually well-marker reptal ridges, about four of which occupy a spuce of two lines. Dimensions unknown, but ereat, large specimens having a length of half a foot or more and a diumeter of nearly wo inchies and a lialf.

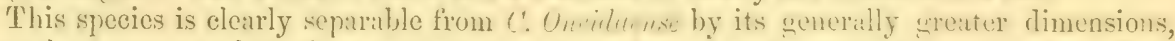
the much greater number of itss septa in examplen of similar dimensions, the alsence of an external vesicular area, and the surfice charicters. Whether it is truly refirable to tire genus Clisinglyflum, however. may be recarded as very doubtful-the central elevation, as in C. Oneidaense, being clearly formed by the tabulae alone.

Loculity and Finmetim. - Fot unenmon in the Corniferous Limestone of IRidgeway.

\section{Gemus Zaphrentis (Rafinesque).}

Corallum simple, turbinate or eylindrical ; calice deep, with a sincle stronely-develoned septal fossette occupying the place of one of the septa ; no columella ; tubulo well derelnred, bearing upon their upper surface a series of septa, which extend from the epitheca, neirly or quite to the centre of the corallum. Whe interseptal loculi usually uninterrupterl except hy the tabulix, but sometimes interfered with by discepiments at the circumference of the coral, giving rise to an outer area of vesicular tissue.

The genus Zaphentis of Rafinesque is identical with the genus Caninir of Michelin, and is one of the most natural groups of the Cyathophylloid corals. The most typical forms 
of the genus are readily recognized by their thin epitheca, the presence of tabula extending quite across the theca as unbroken partitions, the extension of the septa to or near to the centre of the theca, the absence of a columella, and the generally open and uninterrupted condition of the interseptal loculi, except for their being partitioned off by the tabulæ. In some of the forms of the genus, however, the continuity of the interseptal loculi is interfered with, not only by the tabulæ, but by vesicular dissepiments whiclf appear to be independent of the tabula; so that there is a central tabulate area, and an external vesicular area. There is also evidence that the tabulx, though extending quite to the epitheca, are, in their exterior portion at any rate, of the nuture of dissepiments placed nearly at the same level in successive interseptal loculi. According to Mr. Billings, also, a well developed or rudimentary columella may be present in $Z$. prolifica, this structure being otherwise unknown in the genus.

Three species of Zuphrentis, viz.: Z. gigantew (Lesueur), Z. prolifica (Billings), and Z. spatiosa. (Billings), have been already recorded from the Corniferous Limestone of Western Ontario, all of which have come under my notice, whilst I have to record an apparently undescribed form. I have also a small cylindrical, spinulose form, allied to $Z$. spinulose (Edr. $\&$ H.), or to Z. spinulifera (Hall), though apparently distinct, which, in the absence of specimens showing the internal structure, I shall leave undescribed.

\section{Zaphrentis gigan'sea (Lesueur).}

(Plate III. Figs. 1, 1a).

Caryophyllia gigantea (Lesueur).

Zuphentis gigantea (Edwards \& Haime). Pol. Foss. des Terrs. Pal. Pl. IV., Fig. 1.

Zuphrentis giguntea (Billings). Cunudiun Journal, New Series, Vol. IV., p. 121.

Corallum simple, cylindro-conic, varying from a few inches up to two feet or more in length, and from one and a half to three inches in diameter, usually more or less curved. Cavity of the theca partitioned off by a well developed series of tabula, which are more or less flexuous centrally and are bent downwards as they approach the epitheca. Septa from seventy to one hundred or more in number, unequally developed, or alternately large and small, extending upon the upper surface of the tabula nearly to the centre, where they are usually more or less flexuous. A single well marked septal fossette upon one side, extending nearly to the centre. Epitheca with numerous shallow encircling ridges and aunulations of growth, which vary in size but are not sharp-edged; and also with costa corresponding with the septa within.

According to Mr. Billings, the septa in this specics vary in number from seventy to eighty. In the examples which I have seen, however, the septil are alternately large and small and, crunting in those of both sizes, attain to the number of one hundred or nore. They thus come to resemble large specimens of the form described by Mr. Billings, under the name of Z. mrolificu, from which they may be distinguished by the fact that the latter species is not said to attain a length of over five inches, or a little more, whilst the radiating septa reach the number of one lundred and twenty, or one hundred and filty. Our specimens, on the other hand, must have attrincd a length of from niue to twelve inches or more, and do not aplear to hare more than one hundred and ten septa at the utmost, whilst their form is cylindrical, or cylindro conical. and not turbinate. I am not satisfied, however, that all the examples which I have here included under $Z$. gignntea, are really referrible to this species, nor that the large and small forms of $Z$. prolifice (Billiogs), cau be retained under a single specifie title.

Zurvhrentis gigunter (Lesuenr) must nut be coufounded with the large Carboniferous species described by Michelin and MicCoy, under the vame of Cuniniu (Zuplirentis) gigunteu, and by Hdwards and Haime, under the name of Zaphrentis cylindrica.

Loculity and Formution.-Corniferous Limestone of lidgeway, Port Colborne, Walpole, and numerous other localities in Western Ontario.

\section{Zaphrentis fenestrata (Nicholson).}

(Plate IV. Fig. 1.)

Zaphrentis fenestrata, (Nicholson), Cunatian Nuturalist, Vol. vii., No. 3, 1873.

Corallum simple, cylindro-conical, curved. Tabula well dereloped, remote, bending downwards as they approach the outer wall. Septa strong, equally developed, extending 
nearly to the centre of the coral, apparently forty-eight in number. Epitheca thin, with a fer shallow undulations of growth, but apparently destitute of costæ.

This species is closely allied to the preceding, but appears to be clearly distinct, thour the above deveription is founded upon but a sinsle specimen. It differs from Zuphrentis giganteu chicfly in the greater proportionate thickness and much smaller number of the septa, and the greiter remoteness of the tabule. The former of these characters, as well as the fact that the septa are equally developed, separates it from $Z$. prolifica.

The tubule of the circumference of the coral, where they hend downwards to meet the epitheca, scem to be clearly of the nature of dissepiments, as they are not placed at exactly the same level in contiguous interseptal loculi. The specifie name is intended to commemorate the peculiar fenestrated appearance exhibited by portions of the coral from which the epitheca has been removed, when the interveptal loculi are seen to be ero-sed at intervals of from two to three lines, by the obliquely deseending tabule producing a series of oblong fenestrules.

Length of the only specimen observed, five inches; diameter of summit, one and a half inches; calice and fossette, unknorn.

Locality and Formation.-Corniferous Limestone, Port Colborne.

\section{Zaphrentis prolifica (Billings).}

(Plate III., Figs, 2, 2a.)

23.

Zuphrentis prolifica (Billings), C'unadian dunrual, New Series, Vol. iv., p. 121. figs. 22,

"Corallum simple, turbinate, curved, with a few broad, shallow, encirelingr folds. Septal fossette of a pyrifurm shape, cradually enlareing from the marcin towards, but not quite reaching, the centre; variable in its josition in relation to the curvature of the fossil Radiating septit in the adult specimens between sixty and seventy of the larerer size, alternating with a like number of smaller ones; the former, $\mathrm{i}$; inme of the indiviluals extending to the centre on the buttom of the eup, where they are sumally twisted or irrewalurly contorted : in other specimens, bot reaching the centre, which is then necupied by a smonth spacs, or often with a columellat elongated in a direction lrmii the reptal the to towark the opposite side. The septat are also sharpedged for almost hali" the distanes from the boitom of the ceup to the mangin, then become gradually less projecting, until at the edge of the eup they are reduced to mere flat rounded ridges. Length, from linur to fire inches, or a little more; width of cup, from two inches to two inches and a-half ; depth of cup, about one inch.'

"Very numerous specimens of youm individuls uf this species, one inch and a half and upward in length, and with fifty or more principal radiating septr, oceur with those fuld

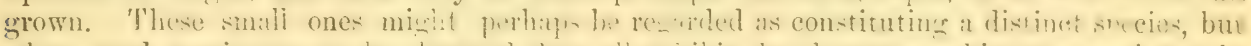

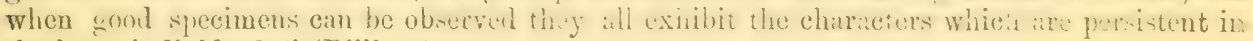
the large individuals" (Billings).

Whil-t having the impresion that the small eximples just alluded to are specific $\cdots$ lly dictinet from the latger ones with which they are mited by ilr. Billings, I must freely admit that on collections are not sufficiently extensive fir me to proununce a decided opinim upos: the subject. Large specimens, indeed, having the chancters a cribed by Mr. Billines to $Z$. Imolifin, are far from common, and I have not com alcros more than four or five : whilst the smaller examples are exceedingly abundant.

The hirger examplesare distinguished from $Z$. finmt. 1, by their smaller dimensions, their turbinate form, the shime of the forsule, and the mich seater number of the septa and their rounded edges where they approach the margin of the cup.

The smaller examples, as a rule, exhibit characters by which they can be readily distin. suished. They are most commonly about an inch and a half in length. but vary from three quarters of an inch up to three inches. The calice is vry deep, but is extremely oblique, its greatest height being on the side of the convex curvature of the coril. The septil are alternately lirge and small, and the primary septa are always more or less bent and contorted as they approach the centre. The tabulie are bent downwards ou approarding the wall. The epitheca in perfect specimens exhibits a few broad and rounded undulations of growth, wit? obscurely marked costa corresponding with the septa within. Mfore crmmonl the epithee: is denuded, being very thin, when the edges of the septa appear conspicunusly on the surface of the coral. 
The occasional presence of a colımella is a very anomalous feature in this species, not being known to occur in other members of the grenus. Mr. Billings, from an exanination of a large number of specimens, concludes, lowever, that the species must be retained in Zumhrentis, as he finds a graduated series of forms between those with no columella and those in which this structure is large and well developed.

inculity and Formution.-Extremely abundant in the Corniferous Limestone of Rama's Farm, Port Colborne. Also, in the Hawiltou Group of Bosanquet, near Widder.

\section{Zaphrentrs spatrosa (Billings).}

"Corallum short, turbinate, moderately curved and very broadly expanding. At the marcin of the cup about ninety radiating septa, alternately a little unequal, and with their edges broadly rounded, as in Z. prolifica. Length, measured on the side of the greater curvature, about three inches; width of cup two inches and a balf. Septal fossette unkuown.

"This species is closely allied to $Z$. prolificu, and may, perhaps, be united with it when its characters become more fully known" (Billings).

I have nothing to add to the above brier description, which has evidently been drawn from imperfect specimens. There are only a few examples in my collection, which I should be disposed to refer to this species; but the reference is uncertain, as hardly anything can be made out of the internal characters of the specimens in question, beyond the fact that they are almost certainly referable to $Z$ en hincutis, and that the very broadly expanding form separates them from any other known Corniferous species.

Locality und Firmation. - Corniferous Limestone, Rama's Farm, Port Colborne (Billings). Ridgervay and Hagersville (Collection of the author).

\section{Gemus Heliophyllum (Hall).}

The genu' II liophyllum is very closely allied to Cyathophyllum, and the following are the definitions of it given respectively by Milne Edwards and Haime, and Mr. Billings: -

1. "Corallum simple. Septal apparatus well developed and producing later:i lamellat monlougatious, which extend from the wall towards the centre of the viscerai chamber, so as to represeut ascending arches, and to constitute irregular central trfule, and which are inited tuwards the circumference by means of vertical dissepiments." (Milue Edwards ami Haime.)

2. "Corallum simple or aggregate; radiating septa well developed, obliquely striated on their sides by thin elevated ridges, which extend from the outer wall in an upward curred comrse towards the centre. These ridges are convected by numerous thin lamina, which divide the spaces between the septa into small sublenticular cells. "The trausrerse dialumigms are thin, flexuous, and confined to the central portion of the coral" (Billings).

The internal characters which distinguish corals of the genus /Itimplyyllum. (ITall) are thus of a somewhat complicated description. The septa are well developed, and extend nearly or quite to the centre of the theca, where they are often somewhit twisted; but there is no columella. A central tabulate area exists, but of very circumseribed dimensions. Extemalsy to this tabulate area, the intersepial loculi are diviled into cells or small compartments by the intersection of two sets of dissepiments having different directions. The dissoniments of the first and most conspicnous set are directed from the internal surface of the wall obliruely, inwards and upwards towards the centre, in a succession of arches the convexities of which are turued upwards. These dissepiments doubtless correspond with that circumferential portion of the tabula which is bent downwards towards the base of the eoral in species of $Z$ inh rentis, Clisinglullum, Diplygllyllum, de. When these dissepiments are more or less implerfect or have suffered destruction, they leave upon the flat surfaces of the septa a corresponding number of arehed stria or ridges. Similarly, iu the culice of the coral these diswepiments appear on the free edges of the septa as so many short spines. The dissepiments of the second s:eries are more delicate, more disconnected and much more variable in their direction than those if the preceding series. Sometimes they are nearly vertical, or in other words, are mretty nearly concentrie with the theea. Sometimes they are not far from the horizontal, and intersect the dissepiments of the former series at a very acute angle. Most commonly they are lirected inwards and downwards from the theca towards the centre, so as to cut the dissepiments of the preceding series nearly at right angles. Decorticated examples of Heliopliyllum from the Corniferous Limestone exhibit a most characteristic appearance, due to the intersection of the 
septa and filled up interseptal loculi with the dissepiments of the first-mentioned series. In this wuy is produced a succession of vertical ridges and intervening sulci crossed by numerous curved or sharply-zig-zagged encircling ridges.

The species of Helingluyllum. which have been described by Mr. Billings as occurring in the Devonian Rocks of Canada are II. Eriense, II. Cunnupuense, II. Canudense', H. rolligutum, Ii crigum, $H$. Hulli, and $H$. tmuisptutum, the first five from the Corniferous formation, and the last two from the Hamiltun Shales. All of these, except H. tenuicelutum, have come under my notice as occurring in the Corniferous Limestone of W'estern Ontario ; and I have also some new forms to record.

\section{Helophyllom Canadense (Billings).}

\section{(Plate V. Fig. 1.)}

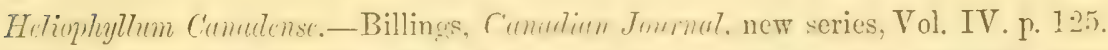

C'orallum simple, turbinate. Septa between eichty and ninety at a diameter of an inch and a half, carrying on their flat surfaces strone arched stria at distances of from two-thirds of : line to one line, and on their free edges hlunt spines placed at similar distances. Binthee: Fi:h strone sharp-edged encircling folds and annulitions of growth. "In the botom of the sup the septa reach the centre, and are there twisted tonether so as to form a somewhit solid slevated pisendo-columella, around which thicre is a deep space oceupied only by the s'pta." (Billings).

Dimensions varying from two inches uy, to half a font or more in length. One silecimen in a jerfect state of preservation meatsured two inches and a half along its convex curvature, and one inch and a cuarter along its concave curvature, the diameter of the cup being a little wer an inch and a hall" and other frecimens are still more broadly expanding: 'This is,

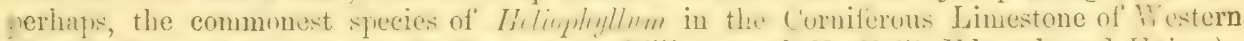

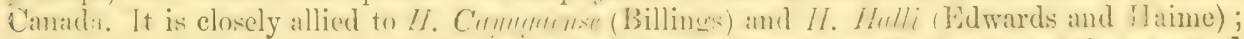
differing from the former chicfly in net having a sments s suce at the bottom of the cup, and

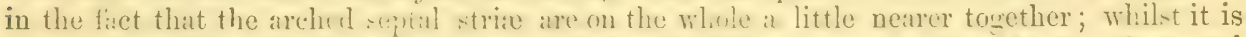
distimashed from the latter ly its cenerally sualler dimencions, and by having the septal spines and stria more remote.

Acending to BIr. Billings, the epithen is sometius:smoth, and there appears to be a septal fossette.

Loculity and Formation.--Coniferous Limestone, Port Colborne; Lot 6, Con. 1, Wainflect; and other localities in Wrestern Ontario.

\section{Helopitylum Colbornewse (Nicholson.}

(Plate V. Fig. 4.)

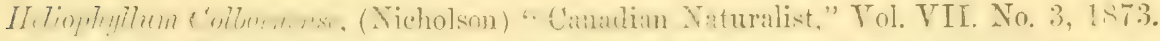

Corallum simple, eylindrica!, not expandius towards the calice. Septa sisty at a linmeter

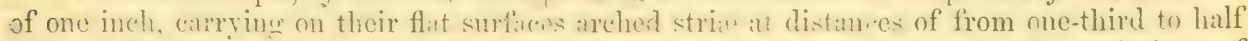
a line. Hilitheca with numerous rombed or sharp-edeerl enn-trictions and annulations of crowts. A flat space at the bottom of the eup, to the centre of which the septat extend. Cup deep; fossette unknown.

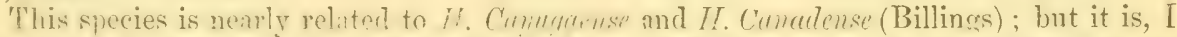
think, decidedly distinct. It is distinsuished from $I T$. ('ementense by its eylindrical and not broadly expmoling form, the eup beinge equal to or lese than the diameter of the corat at a point angurently a little above the base, by the flittening of the hottom of the ealice, by the smaller number of septa, and by the greater clnseness of the areherl septal stria. From II. Cuynumat, the present species is distinewished by its much smaller thickness, its cylindrical but noi expanding form. the smaller number of septa, and the eloseness of the septal strie.

The leneth of $H$. ('ollonrmise must have been over three or four inches, but none of my specimens are perfect. The dimensions of a broken individual are: length two inches and a Inalf : diameter of broken base one inch; diameter of cup ten lines; depth of eup four lines. In another, also broken, specimen, the length is two inches and a quarter; the diameter at the 
fractured base thirteen lines; the diameter of the cup one inch, and the depth of the cup five lines. Other examples apparently referable to this species exhibit a dianeter of from one inch and a quarter to one inch and a half.

Locality and Formation. - Corniferous Limestone of Port Colborne.

\section{Heliophylutu Caydgaense (Billings).}

(Plate V. Fig. 2.)

\section{Heliophyllum Cayugaense (Billings), C'unulian Jourul, new series, Vol. IV. p. 124.}

Corallum simple, turbinate, straight or curved. Septa ninety at a diameter of two inches; one hundred and eighty at a diameter of three inches and a half. Arched septal strix and spines thick and strong, separated from one another by intervals of a line or a little less. Calice with a flattened space at the bottom, and a septal fossette on one side. Epitheca with numerous sharp encircling ridges and folds of growth.

This species is closely related to $H$. Cunalense (Billings), from which it is separated by the posscssion of a flattened space at the bottom of the cup, and by the somewhat greater remoteness of the septal strix and spines.

Specimens with a calice of two iuches across, seem to have been about five or six inchef in length, but individuals of the species appeitr to have attained a much larger size.

Lnculity and Formution.-Rare in the Corniferous Limestone of Port Colborne, and other localities in Wainfleet.

\section{HeLiophylum Haidi (Edwards and Haime).}

Strombodes helianthoides (Phillips); Pal. Foss. p. 10. Plate V. Fig. 13. a.

IIeliophyllum Halli (Edwards and ITaime) ; Brit. Foss. Corals, p. 235. Plate II. Fig. 3, and Pol. Foss. des Terr. Paléozoiques, p. 408; Pl. VII, p. 6.

Heliophyllum Halli; (Billings) C'rnadian Jomrnal, New Series, Vol. IV. Fig. 126.

Corallum simple, broadiy turbinate, cylindrical, or cylindro-conic, often varionsly curred. Siepta 80 to 85 , sliently twisted towards the centre. Septal ridees and spines separited hy intervals of from hall to one-third of a line, or eren less. Calice cireular, moderately deep, with a swall septal fossule. Epitheca with encircling amulations of growth, but seldom exlibiting septal ridges when perfect, or at most very faintly.

The form and curvature of this species are extremely variable, and the size no less sn; whilst the intervals between the septal spines and stripe vary so much that it seems doubtful if much reliance can be placed on this character in the diserimination of species. The examples of this species from the Corniferous Limestone are mostly of large size, and are not particulirly well preserved. Those from the Hamilton group are as a rule small, and occur in a state of exquisite preservation.

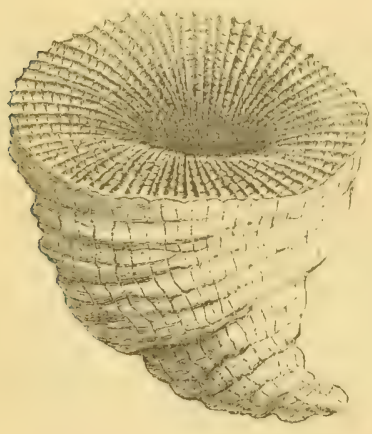

Fig. 4.

One very marked feature in Heliophyllum Halli, as exhibited in all the Hamilton examples except the smallest, is the mode of growth, which is by a peculiar form of calicular gemmation. When the coral has grown to a certain length, the epitheca gradually extends over the original calice in whole or in part, and a fresh corallite is produced from the primitive oral dise by calicular gemmation, generally from one side of the old cup. After this has lived for a certain period, a third cup is produced in a similar manner; and so the process may be continued, till an aged specimen may consist of six or eight cups arranged in a vertical series, each springing from some portion of the calice of its predecessor. This mode of growth, also, causes a singular irregularity in the form of corals of this species, old examples often looking like a succession of inverted cones inserted

Heliophyllum Halli(Elw. \& H.). A young specimen, from the Hamilton Formation of Arkona.

one into the other, whilst the curvature of the whole becomes 
cups in different directions. True parietal gemmation, on the other hand, I hare never noticed to occur in this species. As a similar mode of increase exists in Cystiphyllum vesiculusum, as occuring in the Hamilton Group, and as it has not, so far as I know, been obserred in the examples of $I I$. I Hulli from the Corniferous Limestone, it seems possible that it is a habit of growth induced by some peculiarity in the surroundings of the coral-such, for instance, as the slow but regular deposition of fine clayey sediment.

Helimphyllum Hulli is very elosely allied to $H$. C'curetense, and I should be inclined to doubt if any distinction of importance between the two species can be maintained. Large examples of $H$. Hulli, such as oceur in the Corniferous, are separated from $H$. Cenculense by their more shallow calice, the comparative closeness of the septil strie and their cylindrical or cylindroconical form ; but young specimens of II. Hrelli are often very broadly expanding and turbinate, and the intervals between the septal spines and stria do not appear to be constant.

Small examples of Helinpluyllum Hulli have a length of half or three-quarters of an inch, with a diameter of calice of from three-quarter: of an inch to an inch and a quarter. Lurrge examples may have a length of from fire to six inches, with a diameter of calice of two inches and a half: There are also more cyludical specimens, apparently not separable from this species, which may have a length of two iuches or over, with a diameter of calice of not more than from three-quarters of an inch to an inch.

Locality and Formution. - C'orniferous Limestone of l'ort Colborne ; Con. 1, lot 6, Train. flect; Hagersville. Extraordiuarily abundant in the Hamilton Formation of Bosanquet, along the course of the Rivitre aux Sables, Alko in the Devonian Limestone of Devonshire, England (Phillips, and Edwards and Haime).

\section{Heltophyllum sub-cespitosum (Nicholson).}

\section{Iteliophylluin sub-cerspitnsum (Nicholson), Giculnuicul Murysiue, Feb., 1871.}

Corallum, small, simple or compound, cylindrical, or slightly expanding towards the calice. Arehed septal stria and spines from a third to a quarter of a line apart. Callica cral or circular, shallow. Sopta apparently sixty in number, at a diameter of eight lines. Fipi-

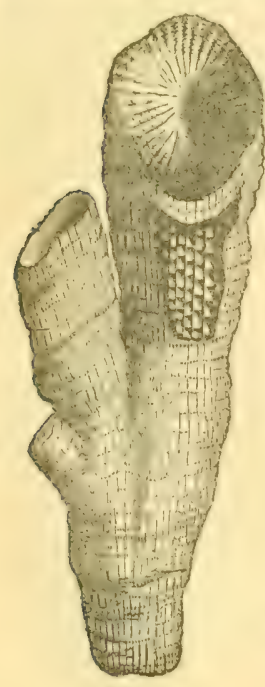

Fig. 5.

Helimphr?um sub-crespitinsume (Nich.), Hamilton Formation, Arkona. theca with numerous annulations and constrictions of growth. Occasional individuals, with the other characters of the species, appear to be simple, but the majority of examples increase by the production of lateral buds. The new corallites thus produced are few in number (generally not more than one, two, or three), and are directed upwards nearly in the direction of the parent corallite.- In some cases calicular gemmation appears also to occur.

$H$. sub-crespitosum has a general resemblance to Cyathopluyllum ccespitosum of Goldfuss ; but the presence of well-marked septal striee and septal spines proves it to be a true Heliophyllum. The latter species also is "fasciculated or astræiform," and increases principally by calicular gemmation; whereas $H$. sub-ca'spitosum never produces sufficient buds to form aggregations of any size, and the increase is principally by lateral gemmation. It is, further, distinguished from the other forms of Heliopleyllum by its comparatively smali size, its cylindrical form, and its mode of growth. H. proliferum (Nich.) increases in the same way, but is a much larger species, and is distinguished by other characters as well.

Young individuals of $H$. sub-ceespitosum are usually strongly nodulated with irregular growth-swellings, and have a length of from half an inch to an inch, with a diameter at the cup of from two to three lines. Large individuals have a length of from two to three inches, with a diameter of calice of from eight to ten lines.

Luculity anel Fornution.-Common in the Mamilton Formation at Bartlett's Mills, near Arkona, in the Township of Bosanquet.

\section{Heliophyllum Proliferum (Nicholson :}

Corallum large, simple or compound, growing socially in particular localities, where numerous individuals oceur together nearly in contact though not organically connected. Form cylindric:s, with numervus irregular growth-swellings in the majority of instances. 
Calice moderately deep, with about sixty septa at a diameter of fourteen lines. The septa are unequally developed, and extend to the centre of the calice, where they are usually more or less twisted, and are sometimes elevated in tle form of a central boss. Arched septal strie and spines from a third of a line to half a line apart. Some individuals appear to be simple, but most increase by the production of lateral buds, which spriug from the parent corillite in an obliquely ascending minner. The epithect exhibits numeruus eucircling strie and annulations of growth.

H. proliferum is readily distinguished from the other speeies of the genus, by its elongated cylindrical form ; its increase ky lateral gemmation, and its social habit. Not only is the species composite, in thesense that most of the individuals produce lateral buds, but, so far as I bave observed, it is strictly social, vast numbers of individuals occurring together, groming rertically side by side butseparate. I have not seen more than one or two buds borne by a single parent corallite, and ealieular gemmation appears to be unknown. The only other IIeliomllylinm known toinerease by lateral gemmation is $H$. sub-caspitosum, but this is a very much smaller form, and is solitary in its habits. Detached individuals of $H$. proliferm in which budding appears not to have taken place, may usually be recognised by their great length and almost strictiy eylindrical form, there being little or no increase of diumeter as the cup is appronched. Lurge individuals have a length of seven or eight inches or more, with a caliciue diameter of an inch and a half, and a similar diameter throughout.

Loulity am Frmmution.-. Extrandinarily abundant in one bed in the Corniferous Timestone of Ridgeway.

\section{Heliophylutm ERiense (Billings).}

\section{Heliophyllum Eriense (Billings); Canalum Jommul, New Series, Vol. IV. p. $1:$ t.}

Corallum elongate, turbinate, straight or curved. Septa from reventy-four to one hundred and fifty in young and old individuals respectively. Septa extending to the centre of the calice carrying on their sides delicate arched stria separated by intervals of from a quarter of a line to a sixth of a line. Free edges of the senta "deuticulated with from tive to suven short spines in the space of one line." Elitheca with shirly annulatious and encircling ridges of growth.

This species is readily distineuished by "the elosencss of the arched strice on the sides of the septa, and the minute denticulation on their free edges" (Billings). H. Ericuse is sxceedingly variable in its dimensipns, varying in length from an inch and a half up to nearly a foot, and as regards the diameter of the cillice from an inch and a cuarter up to threeinches and it half. The calice is deel, and there anperis to be an obscumespeptal fossula on one side.

Laculity aml. Fonmution. - omifurous Limestone, Lot ¿9, Con. 3. Walpole ; and Port Colborne. Very rare.

\section{Heliophyllum colligatum, (Billings).}

(Plate V. Figs. 3, 3a).

IFliophyllum colligutum (Billings); Cumaliun Journal, Nerv Series, Vol. IV. p. 126.

"Corallum forming large mases of lous slender corallites, which are ennnected towether at intervals of from two to four lines by periodic expansions of the cup : radiating septit about fifty-two; diameter of the corallites where constricted five lines; and of the expanded cup six to ten lines. Amoug the full wrown there are iuterspersed some that are immature amd of smaller size. The cup is shallow, the sides of the septa striated with from six to cimht arehed rideres in one line, and their free ederes dentienlated with the same number of minute simes. In the central area the transverse diaphragms are well developed, and sometimes constitute a preudo-columella, which exhibits itself in the shape of a sunsll elevated boss in the centre of the eup" (Billings).

This species eannot be confounded with any other. It is remarkable amongst the typical speeies of this genus in being compound instend of simple; and it has the tabulae unusually well developed, constituting a central area into which the septa, as a rule at any rate, do not anter. The epitheca is transversely ringed with annulations of growth. and, in the periodic expansions of the eup, with numerous fine encircling strire, which are crossed by the longitudinill lines which mark the position of the septa As jointed out by Mr. Billiugs, $I$. colligatum forms a transition between Heliophyllum and Phillipsastraea.

Walpole.

Lorulity and Furmation.-Corniferous Limestone of Rama's Farm, Port Colborne, and 


\section{Heliophyluda exiguUa (Billings).}

\section{$\& 10$. \\ Heliopluyllum exiguum(Billings), C'unadiun Jour. New Series, Vol. V.p. 261. Figs.9}

"Small, turbinate, more or less curved, often flattened on the side of the convex currature; radiating septa between sixty and eighty; about six obscure arched strix to one line on their flat sides, and the same number of spines on their edges. The depth of the cup is equal to oue fourth or one third of the whole length of the coral. In small specimens, the margin of the cup is thin and sharp; but in large outs rounded, and one line or a little more in width. About one half of the radiating septa reach the centre, and form a small rounded elevation on the bottom of the cup. 'There is a septal fossette on one side, which, in all the specimens I have seen, reaches the centre. The surface exhibits a fer sharp constrictions of growth, with rounded anmulations hetween them, the latter often abruptly terminated on their upper sides. In very perfict sfecinens, fine encirclines stria of variáble size, apparently from eight to fifteen in the width of one line. The horizontul stria. which indicate the number of septa, are distinetly visible but not strongly marked. The position of the septal forsette is indicated on the outside of the cup by two sental ridses which extend the whole length of tho c rall, and coustitute one of the lines along" which the younger septa were added from time to time.

"The greater number of the specimens are from six to nine lines in length, but some are full one inch. The width of the rup is always a little lesis than the leugth of the entire forsil. The most common number of septa is sixty. The arched stria and spines are not often preserved" (Billings).

I have been thus particular in quoting the de-cription given by Mr. Billings of this species at full length, as in studyine it, I have met with creat difficulties, which I cannot yet entirely explain. The fow ex:mules which I cullextert at Inamit's Farm, Port Colborne, (the lncality given by Mr. Billings), that I should be dispen-ed to refer to this species, exhibit only the form of the corallum, the epithecal. and the exd of of the calice; and the characters of these are sufficiently distinctive, so tar at iny rate, as the other C'andian species of Helimplinglim are concerned. The coral is small and turbinate, and is distinctly flattened along its conver curvature; the epitheca is thick and contimous, and is thrown into strong encicling ridues and annulations of growth, the vertical lines indieating the septa being very faintly marked, and the septa are alternately laree and suall, and are not denticulated on their flat sudes. One perfect specimen only ( $F$ ig. (i) have I obtained, showing all the internal characters, from the Corniferous Limestone of Hacersille; and this shows conclusively the distinctness

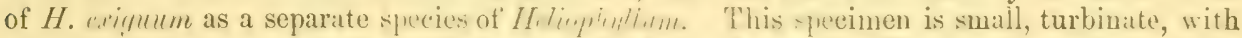
a constricted peduneulate base, the longest side being flattened. 'The total length along the longest side is eight lines, nu the shortest side four line: the diameter of the calice being seren lines. The calice is distinctly quatringular, moderatedy deep, with thickened mareins, and a very well marked septal fisette. The septa are sixty-four in number, alternately lirve and small, with about five arched stria on their flat sides aud the same number of short spines on their edges. The septal to-sule correspmuls with two primary septa, which extend the whole leneth of the coral. and frum the two sides of which the other septa diverce; a peruliarity which I have failed to observe in the exmmples from Port Colborne. The epitheca shows vertical septal striæ, and encircling, annulations of growth.

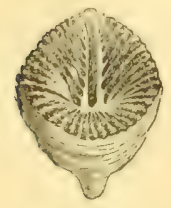

$a$

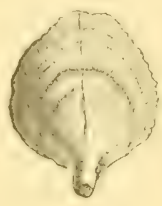

6
Fig. 6.

Heliouhyllum exiguum (Billings) ; a, Front view showing the calice; $b$, Dorsal view of the same. Corniferous Limestone, Hagersville.
Accompanying the specimens of $H$. exigurm (Bill. ings), at Port Colborne, I have found a large number of specimens which agree in some striking characters with H. exigurm, but which differ from this species in other characters equally striking--and that to such an extent that I do not see how they can be referred to the genus Heliophyllum at all, seeming rather to belong to the genus Petraia. The discrepancies of observation indicated here, I do not pretend to reconcile; but I shall provisionally describe the specimens in question as distiuct, under the name of P'etruiu Logani. 


\section{Petraia Logani (Nicholson).}

\section{(Plate III. Figs. 3-3f.)}

\section{Petruia Loguni, (Nicholson), "Canadian Naturalist," Vol. VII. No. 3, 1873.}

Corallum small, turbinate, more or less curved, almost trigonal in transverse section, owing to its being flattened on the side of the convex curvature, and also on the lateral surfaces. Septa twenty-six or twenty-eight a little above the base, but sixty or more at the cup, the increase of number being due to the bifurcation of ench primary septum at a distance abrut a line and a half above the base, and also to the intercalation of new septa along both sides of a line which runs along the dorsal or convex side of the coral from top to bottom. This line is marked on the exterior by two primary septa, which form a prominent ridge externally and pass inwards to the eentre of the coral. At the margin of the cup the septa are somewhat unequally developed, being alternately larger and smaller, the larerer primary septa being prolouged inwards to the centre of the coral, where they become somewhat bent and twisted together. No columella appeurs to be present, nor are there any tulule. The flat sides of the septa are furrrowed with a succession of deep grooves, about four or five in the space of one line, which are directed in an obliquely ascending and arching manner from the wall towards the centre, the interspaces between them being tumid and rounded, and thus imparting a erenulated appearance to the outer edges of the septa when exposed. These arching grooves are not connected with lamellar dissepiments having a similar direction, but the septil for some little distance below the cup are united by delicate transverse dissepiments. The epitheea is marked with a few ammulations of growth, which are mostly very obscure, and with well marked costæo corresponding with the septa.

In nune of the specimens in my possession does the epitheca extend more than half an inch ('ft:u less) above the bise of the corallum. Beyond this point to the margin of the calice the edges of the septa are seen with their characteristic cremulated appearance, and united here and there by minute dissepiments. As already noted, the flattened convex side of the coral always exhibits two pre-eminently large septa produced by the splittiner of one, which run from the top to the bottom of the conal in a straight line. The remaining septia are directed obliquely from both sides towards this central pair; so that new septa are intercalated along this line in proceeding from the base to the calice. It is probable that these two septar may mark the position of a fossule in the cup, but none of my specimens exhibit the interior of the calice, and I am, therefore, unable to speak positively on this point. For the same reason I can say nothing as to the condition of the free edges of the septainternally.

The total length of the corallum is from three-quarters of an inch to one inch, the diameter of the cup varying from half an inch to nearly three-quarters. The calice is oblique, so that the greatest length of the coral is along its convex curvature.

Petruce Lonuni is closcly allied to I'etruice (Turbimulupsis) pluriralialis (Phillips), with which I was at first sight disposed to identify it. It is, however, readily distinguished by the fattening of the convex curvature and lateral aspects of the coral, and by the smaller number of radiating septa. As regards other more minute characters, the published descriptions of P. plariadiulis are not sufficient to enable any oloser comparison to be iustituted with advantage between the two species.

With regard to Ileliopleyllum eriyunn (Billings), it may be well to present, in a summary form, the points of agreement and difference which apyear to exist between the two species:-

1. lioth corals are of the same general form and size, and both oecur in the same formation and at the same locality.

2. Both possess a principal pair of septa, which are visible externally as two straight rideres extending from the top to the bottom of the coral, the remaining septa being directed obliquely towards this line on both sides. (When writing my original deseription of $P$. Logani

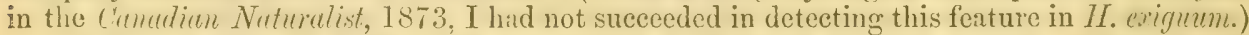

3. The number of septa in the cup appears to be about the same in boih, though stated to be sometimes as many as eighty in $I I$. ceriyum, whilst they never appear to exceed sixtyfive in P. Logani.

The above are the chief points of anreement, but there are the following noints of cifference:- 
1. Heliophyllum exiguum, though this is not specially alluded to, must possess more or less well developed tubule ; but no traces of such structures can be detected in $P$. Loyfoni, in longitudinal sections or in fractured specimens.

2. The septa in $H$. exigum exhibit on their flat sides "about six obscure arched strice to one line." Those of $P$. Logmini exhibit a succession of arched gromees of considerable width, separated by somewhat tumid interspaces; and there are only about four or five of these grooves in the space of one line. Nor does it appear possible that this discrepancy is due to any confusion on my part between casts of $P$. Lumni ind the actual coral itself, such a mistake seeming to be out of the question in dealing with the well-preserved specimens of the Coruiferous Formation.

3. The septa in $P$. Lnguni bifurcate regularly in proceeding from the base to the cup, thus being always arranged in pairs in the upper part of the coral ; whilst those of $I I$. exigum are alternately large and small, and do not appear to bifurcate.

4. When looked at in trausverse sections of the enp, the septa of $H$. esimmm appear to posses: plitin or but slightly denticulited sides, whilst those of $P$. Lummi are furnished with strong tnoth-like dissepiments or spines, which sometimes extend to the contiguous septum.

5. 'The septill ridges on the exterior of $I$ '. Lim.mi are more strongly marked than in H. rimmm; and the epitheca of the former rarely or never appears to extend to the maryin of the calice, thoun it is certainly diflicult to syy pitively whether this apparance is uatural, or is due to the partial decortication of the coral.

Upon the whole, I think that the fossil here described as I'trine Lumini is distinct from previou-ly described forms, and I do not see how it c.m, unsler any circumstances, be referred to the genus Heliopliyllum.

In ality and Furmution. - Not uncommon in the Comiferous Limestone of Ramats Farm, Port Colborne, and also at Hagersville.

\section{Genus Ajrplexus (Sowerby).}

In thic genus the corallum is simple, and in all exwential respects similar to Zw,plement is sxcept that the sepitat are much less highly derelnped, and do not extend to the centre of the coral, so that the talulae are left exprised and free to viers over a wide central area. The following is the only speeces which has as yet been detected in the Corniferous Limestone of Ontario.

\section{Amplexus Yandelli (Edw. \& H.).}

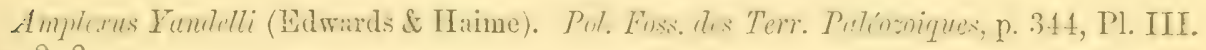
Figs. $2,2 \alpha$.

\section{Amplessus Yandelli (Billings). Canadian Joumat, New Series, Vol. IV., p. 123.}

Corallum simple, eylindrical, straisht or curved. Calice varying in diameter from half an inch uy to an inch and a half. Epitheca marked with from linty five to isty-five strong and ancular septal ridges, which in well-preserved cximples are crosied by fine encircling strix, and a few remote and recular folds of erowth. The septa do not extend more than from half a line to two lines from the wall, leaving the tabula exposed over a large centrul area. The tabula anpear to be generally flat; and the senta have plain sides, and are alternately large and small.

Amplems Jimmt 71 is not a common species in the Corniferous Limestone, and does not apnear, so firr as known, to occur at all in the Hamilton Group. As a rule, it may readily be reconised, even in frumentary specimens, by the surfitec-characters, whieh are unlike those of any other of the simple corals of the Corniferous with which I am acquinted.

Limlity and Formutim.-Corniferous Limestone of Port Colborne. Also near Woodstock (Billings).

\section{Gemus Diphyphyudu (Lonsdale).}

: 'orallum simple, associated iuto large apgregatious of' long slender cylindrical flexuous sorallites, increasing by parietal or calicinal gemmation, and placed usually at a creater or less distance from one auother. Intemally a central area occupied solely by tabula, and usually not encroached upon by the septa, with an exterior vesicular zone occupied by the septa. No columella. 
There has been much difference of opinion as to the validity of the genus Diphyphyllum of Lonsdale, chiefly arising from the fact that its original founder erroneously made its supposed fissiparous mode of division, a generic character, Milne Edwards and Haime, however, pointed out that the mode of increase in the corals referred here is truly by gemmation, and not by fission. Hence, they refused to accept the genus, and placed the corals previously referred here under Cyathopluyllim and Lithustrotion. Upon the whole, however, there can be little hesitation in adopting the view advocated by Mr. Billings, (Cun. Journal, new series, Vol. IV. p. 134, ) and in retaining Diphypluyllum as a distinct genus.

Diphyphyllum, as above defined, differs from Cycthophylluin in its distinctly bi-areal structure, the septa not extending to the centre, as they do in the latter genus, nor being twisted together, so as to produce the appearance of a small columella.

From Lithostiotion, which it closely resembles in most respects, Diphlyphyllum is separated by the invariable absence of a columella. Nilne Edwards and Haime, "British Fossil Corals," p. 195,) express their opinion that the alsence of the columella in Dimhymhyllum is accidental and due to the process of fossilisition. As pointed out by Mr. Billings, however, there cin be no question as to the incorrectness of this opinion. the columella beiug entirely wanting in the most beautifully preserved examples of Diphyphyllum.

From Amplexus, Diphupluyllum is separrated by the general form of the coral, by the greater development of the septa, and by the absence of a septal fossule.

In all essential points of their structure the genera Evirlophyllum and Diphyphyllum are identical, the sole difference of importance being that the corallites in the former genus are united to one another laterally by horizontal root-like prolongations of the epitheca. It must be admitted, however, that specimens of Diphyphlyllum occasionally exhibit similar connecting processes, though these are never developed to any extent, and can only be detected by a careful examination.

The rharacters of the genus Diploplyyllum (Pal. N. Y., Vol. II. p. 115), founded by IJall for the reception of a common coral from the Niagara Limestone, do not appear to differ essentially from those of Diphyphyllum, except that the outer vesicular layer in the former is stated to be separated from the central tabulate area by a distinct mural investment. It is probable, however, that Mr. Billings is eorrect in uniting the two genera.

Two species of Diphlynluylum have been described by Mr. Billings from the Corniferous Limestone of Western Ontario, being amongst the most conspicuous corals of the formation. I have also detected splecimens inseparable from D. grocile of MIcCoy, if indeeu the latter is not truly identical with D. stramineum (Billings).

\section{Diphyphyludi ardndinaceum (Billings).}

\section{(Plate VI. Fig. 1.)}

Diphyyphyllum anundinaceum (Billings), Canadian Journul, New Series, Vol. IV, p. 134.

"Corallum forming large masses of long cylindrical straight or flexuous stems, from three to four lines in diameter, but usually distant from one to three lines from each other: radiating septa thin, betwen forty and fifty in number, rarely reaching the centre; transverse diaphragms turning downwards on approaching the margin; two to four in one line. In some of the corallites the walls are so thin aud closely united that no separation can be observed, but in others of the same cluster an vuter area is distinctly visible. There is usually a circular space in the centre of the corallites, into which the radiating septa do not penctrate; often however they reach the centre. The young corallites sometimes spring from the sides of the parent with a slender base, and curving upwards immediately become parallel with those of the whole group. In large colonies frequent instances may be seen, where, instead of this lateral budding, a bifureation takes place, both branches being of the same size. In large groups, owing to the numerous alditions of young, the corallites diverge slightly, as if radiating from a point. The colonies are from six inches to several feet in diameter, and large blocks of stone are of frequent occurrence, which are penetrated at right angles to the stratification by the closely crowded stems" (Billings).

Diphyphyllum arundinuceum (Billings) is distinguished from the following species chiefly by the almost uniformly greater size of the corallites, which average three or four lines in diameter when fully grown. In shape the corallites are cylindrical, with annulations and 
constrictions of growth; they may be straight, or more or less flexuous; and they vary in their distance apart. The epitheea is marked with numerous extremely close-set and delicate encircling stria, together with more or less conspicuous vertical stria, which mark the position of the septa within. Occasionally, the corallites are united by lateral connecting processes derived from the epitheca, similar to those which characterise the genus Erilophyllum; but these processes are always remote, and are only an occasional feature. The septa are from forty to forty-two, alternately large and swall, and rarely encroaching upon the central tabulate area. The tabulæe are regularly depressed and bent downwards as they pass through the outer vesicular zone on their way to reach the margin; but they are sometimes more or less flexuous. Increase of size, so far as I have observed, seems to be always by the production of lateral buds, but it is possible that calicular gemmation sometimes occurs, and Mr. Billings states that bifurcation of the corallites takes place occasionally.

Very commonly the corallites of this species have attached to their surface the singular adnate coral which I have described under the namo of Aulopori (?) Cunadensis, along with the tubes of a species of Spirorbis.

Lorculity and Formution.-Common in the Corniferous Limestone of Port Colborne, and Lot 6, Con. 1, Wainfleet; also "in various localities in the tornships of Walpole, Oneida, Cayuga, and Wainfleet" (Billings).

\title{
DipHyPHYLLUM STRAMINEUM (Billings).
}

\author{
(Plate V., Fig. 6.)
}

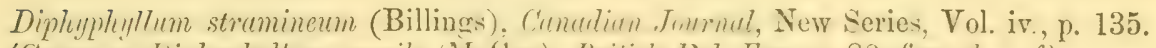
(Compare Diphyplyllum grecile (NcCoy), British l'ul. Foss. 1. 88, figs. d, e, f).

"Corallum forming large masses of eylindrical tubes, averiegun two lines in diameter, and either so closely aggresated as to be nearly in contact, 'r separated from one another by intervals of from one to five lines, the distance varying in different clusters and in different parts of the sime. Sometimes numerous single tubes vecur seattered through the rock, which were probably derived from some disintegrated group. The tubes are either straight or flexuous, smooth, or anmulated hy short encireling felds of growth, the surfice striated longitudinally by the outer edges' of the septa. 'I'he latter are about forty in number, and do not reach the centre. The transverse diaphragms are well developed, slightly convex in the centre, and appear to be suddenly turned down an approaching the margin. The outer vesicular area is thin, seldom exceding one-sixth of the whole dimmeter. The central area altogether occupied by the trausverse diaphragms; sometimes in well-preserved specimens, the septa may be seen extending about half way to the centre, upon the surfice of some of the diaphragms, but in general they are confined to the outer area. In the more dense colonies, the corallites often inosculate, and are sometimes connected by laterial processes, as in the species of the subgenus Eridophyllum" (Billings).

I doubt if the distinctness of this species from Dimhyphly lnm gracile (NaCoy) cau be maintained. The distinction given by Mr. Billings is that the septa of the latter are alternately large and small, whereas in D) stromineum they are all nearly equal in size ; but it may be questioned if this distinction would be alone sufficient to separate the two forms. At any rate, I have found in the Corniferous Limestnne, a number of specimens which agree with $I$ ). yracile in most respects, and which I shall, therefore, describe under that name.

Loculity and Formation.-Common in the Corniferous Limestone of Port Colborne and Lot 6 , Con. 1, Wainfleet.

\section{Diphyphyllum gracile (McCoy).}

(Plate V. Fig. 5.)

\section{Diphyphyllum gracile (McCoy), Brit. Pal. Foss., p. 88, figs. $d, e, f$.}

Corallum forming colonies of cylindrical, straight, or flexuous corallites, the diameter of which varies from two to three lines, being most commonly about two lines and a half. Surface with annulations of growth, and vertical lines marking the position of the septa. These latter 
from forty to forty-four in number, alternately large and small, the small ones being very minute. A well-marked central tabulate area, upon which the septa do not encroach. Tabula bent downwards on approaching the margin.

I can not distinguish our forms from the species described by McCoy from the Carboniferous Limestone of Northumberland, under the name of D. gracile (Pal. Fus. p. 88). Milne Edwards and Haime suggest that 1 ). gracile was founded upon a specimen of Tithostrofion imenulure, in which the columella had been accidentally destroyed in the process of fossilization (Brit. Fossil Corcls, p. 199). This explanation would certainly not apply to our examples, which are exceedingly well preserved, and exhibit no trace of a columella. The only distinction that I can find between the Corniferous specimens and D. gracile is that the former are generally rather over two lines in diameter, but it does not appear that much value should be attached to this.

Locality and Furmution.-Not uneommon in the Corniferous Limestone of Ridgeway.

\section{Genus Eridophrluum (Edwards and Haime):}

"Corallum composite, and increasing by lateral gemmation. Corallites tall, cylindroid, and provided with a thick epitheea, which wives rise to a rertical series of short and thick subradiciform productinns that extend to the next individual and unite them together. Tabula well developed, and occupying the central area circumseribed by the inner wall. Septal apparatus occupying the anvular area situated between the outer and inner mural investment, but not extending into the inner or central area." (Edw. \& H. Brit. Fossil corcls. Introduction p. Ixxi.)

The only difference between Dipllypluyltum and Eridophlyllum is that the corallites of the latter are united at greater or less intervals by horizontal counecting processes. We have seen, however, that similar processes, though not so well developed, are sometimes present in species of Diphyphyllum; and there are also examples of Eridophlyllum in which the cqnzecting processes are few and far between, and are by no means a conspicuous feature. It may be questioned, therefore, if the distinction between Evidopluyllum and Diplly,pluyllum is one that can be maintained.

Three species of Eridupluyllum have been recorded by Mr. Billings from the Corniferous Limestone of Western Ontario, viz. : E. Fencuilumum (Edwards and Haime), E. simecense (Billings), and E. strictum (Edwards and Haime); but only the first two of these have come under my notice.

\section{Eridophylum Simcoense (Billings).}

(Plate VI. Fig. 5.) Fig. 27.

Evitophyllun Simcoense-(Billings), Cunatiun Journal, New Series, Vol. IV. p. 131,

Corallum forming colonies of erlindrical, straight, flexuous, or crooked corallites, from two to three lines in diameter, distant from one another from one to three lines, and united by short horizontal connecting processes at intervals varying from two to six lines. The connecting frocesses are thick where they spring from the will of the corallite, thin in the middle, and again thick where they join the contiguous corallite; and they are often, though by no means universally, all turued the same way in the same colony. T'he surface usually exhibits encireling folds of growth, along with verticul ridges corresponding with the septa. I'here is a well developed central tabuliste area, into which the septa penetrate slimhtly or not at all. The septa are between forty and fifty in number, alternately large and swall.

Typical examples have the corallites straight, with the connecting processes placed at tolerably uniform distances, but many examples occur in which the corallites are very crooked and the intervals between the connecting processes extremely variable. Increase by parietal cemmation, the young individual bending upwards and becoming parallel with the older corallites, is a phenomenon which can commonly be observed.

It is possible, as hinted by Mr. Billings himself, that Eridophyllum Simenense may turn out to be identical with the Upper Silurian species described by Milne Edwards and Haime under the name of $E$. mugosum. The corillites of the latter, however, appear to be decidedly more slender in their dimensions, and they are stated to possess only twenty septa, though 
this latter character may depend simply upon the fact that the small seenndary septa rere nerlected in the enumeration. Upon the whole, howerer, it is safer to keep $E$. Simconst distinct.

Locality and Formation.-Common in the Corniferous Limestone of Port Colborne, Ridgeway, Lot 6, Con. 1, Wainfleet, and also, according to Billings, near the Town of Simcoe.

\section{Eridophyludm Verneutlanum (Edwar?s and Haime).}

Erilophyllum Verneuilınum. (Edwards and Haime), Pol. Foss. des Terr. Paléozoiques, p. 424 , Plate VIII. Figs. $b, b, a$. Fig. 26.

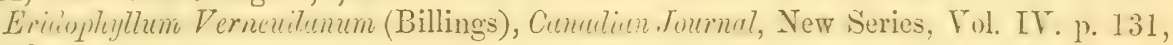

Corallum consisting of cylindrical, straight or slichtly flexuous corallites, from four to six lines in diameter, united by horizontal connectine processes, placed at intervals of from half an inch to an inch and a-half apart. Septa about forty-fire in number, alteruately large and small, extending very nearly to the centre of the corallite, and thus invading the central tabulate area. Septa connected in the outer zone of the corallite by numerous dissepiments. The distance between the different corallites of the colony varies much, being sometimes half an inch or more. whilst in other cases the corallites are nearly or quite in contact.

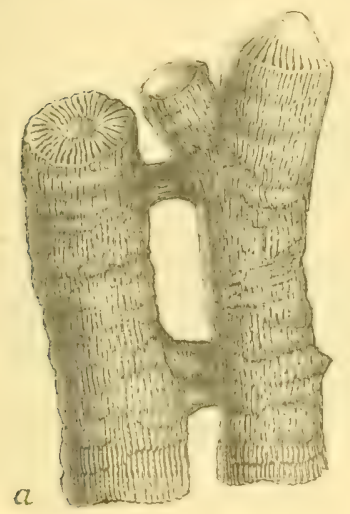

Fig. 7.

Eridophyllum Verneuilanum, (Edwards and Haime) : $a$, Two

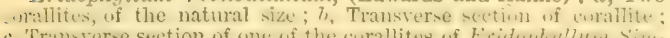
c, 'Trunster-e section of one of the curallites of Eridenthyllum simcoense (Billings). Corniferous Limestone.

Eridophyllum Verncuilanum is readily distinguished from $E$. Sincoense, by the much greater size of the corallites, the much greater remoteness of the connecting processes, and the greater development and inward extension of the septa. Increase by parietal gemmation can often be observed. The epitheca is marked with obscure annulations of growth and rertical stria corresponding with the septa.

In the original description by Milne Edwards and Haime, the septa in this species are said to be only twenty-two in number. As pointed out by Mr. Billing, however, this depends upon their having counted the primary sepita only, the total number of septa being thus the same as in our Canadian examples.

Lnealityand Fmmation.-Corniferous Limestone of lidgerray, common. Also, according to MIr. Billings, in the Corniferons Limestone of Port Colborne, Lot 1?, Cou. 3, Walpule, and near Woodstock.

\section{Genus Cystiphyllum (Lonsdale).}

Corallum simple, turbinate or eylindrical, rarely aggregate. Interior of the theca filled with vesicular tissue; the septa rudimentary or absent.

Five species of this genus, viz.: ( . Simmust, Billings, C. grunde (Billings). C. sulcutum, (Billings), C. Ammianmm (Edwards and Haime), and C. uergrefutum, (Billings), have been described by Mr. Billings, as ocecurring in the Devonian rocks of Western Ontario; and of these all but the last have come under my notice as oceuring in the Corniferous Limestone. C'. rcxicules:m (Goldfuss), also occurs in the Corniferous, and very abundantly in the IIamilton formation.

\section{1. (Yystiphyludi Senecaense (Billings).}

\section{(Plate VI. Fig. 6.)}

Cystipluyllum Senecaense (13illings), Cundiun Journal, New Series, Vol. IV, p. 137.

Corallum simple, cylindro-conic, or cylindrical, elongated, straight or variously curved. Epitheca thin, almost invariably decorticated. Calice deep, smooth, or tuberculated, 
sometimes with ridges representing the septa. Interior of the coral entirely occupied by vesicular tissue, the cells of which are extremely oblique to the surface, or almost parallel with it, and vary from half a line to a line and a half or more in height, the largest being near the centre. Length most usually from two inches and a half to a foot; diameter from three quarters of an inch to an inch and a half.

This species is the commonest of the forms of Cystipinyllum in the Corniferous Limestone. It is allied to C. vesiculosum (Goldfuss), but differs in its lareer and more oblique cells, and its thinner epitheca. Most generally the coral is found in a completely decorticated condition, when the cells are generally seen to be plainly arranged in a succession of infundi. buliform layers, each of which represents a periodic calice; so that the specimen looks as if it were composed of a series of hollow cones fitting into one another. According to Mr. Billings, specimens sometimes reach a length of two feet; but they are most commonly from four or five to nine inches long.

Locality and Formution.-Common in the Corniferous Limestone almost everywhere in Western Ontario.

\section{Cystiphylluar grande (Billings).}

\section{Cystiphyllam grande (Billings), Cunadiun Joumal, New Series, Vol. IV. p. 138.}

"This species is very large, turbinate, more or less curved, and enveloped in a thin wrinkled epitheca. Cup deep, bell-shaped, either striated with the rudimentary radiating septa, or consisting of an uniform surface of the small depressed convex cellular elevations. The growth appears to have been intermittent, or by the formation of successive layers of cells. upon the inner surface of the cup, and cousequently in longitudinal sections the substance of the whole mass is seen to be arranged in a series of funnel-shaned strata, placed one within another. The separation between the layers is much more distinct in some specimens than in others" (Billings).

C. grumle is closely allied to C. vesiculosum, (Goldfuss), and C. Senecaense, (Billings); but it is distinguished from the former by its much larger dimensions, and from the latter by its broadly expanding instead of cylindrical form. 'Though mostly from six inches to a foot in length, Mr. Billing mentions that it attains a length of three teet and a diameter of five inches. It is not a common species. fleet.

Locality and Formution.-Corniferous Limestone, Walpole ; and Lot 6, Con. 1, Wain.

\section{Cystiphylutu Americandu (Edwards and Haime).}

\section{(Plate VI. Fig. 8.)}

Cystiphyllum Americanum (Edwards and Haime), Pol. Fos. des Terr. Paléozoiques, p. 464. Plate XIII. Fig. 4.

Cystiphyllum cylindricum (Hall), Geology of New York, Part 4, p. 209, No. 48, Figs. i and 2. (Not Cystiphyllum cylindricum. Edwards and Haime).

Cystiphyllum Americanum (Billings), C'uncediun Journul, New Series, Vol., IV. p. 139.

Corallum simple, very variakle in form, mostly more or less curved, elongated, cylindrical, sometimes increasing in diameter towards the cup, sometimes diminishing. Epitheca thin, sometimes nearly smooth and with but a few encircling annulations of growth and finc strix, more commonly with numerous pronounced cncircling folds, which are usually sharp. edged and imbricating, but sometimes rounded. Calice moderately deep, usually circular, sometimes disproportionately small as compared with the size of the corallum. Septal furrows in the interior of the calice usually well-marked, but generally consisting of rows of elongated vesicles. The bottom of the calice, also, is usually occupied by a group of larger or smaller bullw. Internal structure vesicular throughout, the vesicles near the exterior varying from less than half a line to a line and a half in width and those of the centre being a little larger. The smallest individual observed had a length of one inch,and a diameter of the cup of half an inch; the largest had a length of four inches and a diameter of the calice an inch and a quarter, but larger individuals than this appear to occur.

In form $C^{\gamma}$. Americanum is extremely variable, the most common type being perfectly straight; and the next most common type being abruptly curved, nearly at right angles, from a 
little above the base, and then continuing straight to the cup. The species is allied to $C$. Senceurnse (Billings), but is distinguished from this by its cylindrical form, and its surfacecharacters, and by the fact that its cells do not appear to he arranged in infundibuliform layers. From C. vesiculosum (Goldfuss), it is distineruished by its smaller size (as a rule), its comparatively smooth epitheca, its shallower and smaller calice, and its cylindrical shape. It also rarely exhibits the calicular gemmation which is so common in the latter species, though this phenomenon can occasionally be observed.

Locality and Formation.--Rare in the Corniferous Limestone of Port Colborne. Very abundant in the IIamilton Formation, at Bartlett's Mills, near Arkona, Township of Bosanquet.

\section{Cystiphyludm vesiculosum (Goldfuss).}

Cyathophyllum vesiculosum (Goldfuss), Petrei. Germ. p. 58, Pl. XVII, Fig. 5, and Pl. XVIII, fig. 1 .

Cystiphyllum vesiculosum (Phillips), Pal. Foss., p. 10, Pl. IV, fig. 12.

C'ystiphyllum resiculosum (Milne Edwards and Jules Haime), Pul. Foss. des Tur.

Paléozoiques. p. 462.

Cystiphyllum vesiculosum (McCoy), Brit. Pal. Foss., p. 71.

Corallum simple, elongated, turbinate or cylindro-conic. sometimes nearly .cylindrical. Epitheca excedingly strong, exhibiting umerous fine encireling strix, along with many wel!

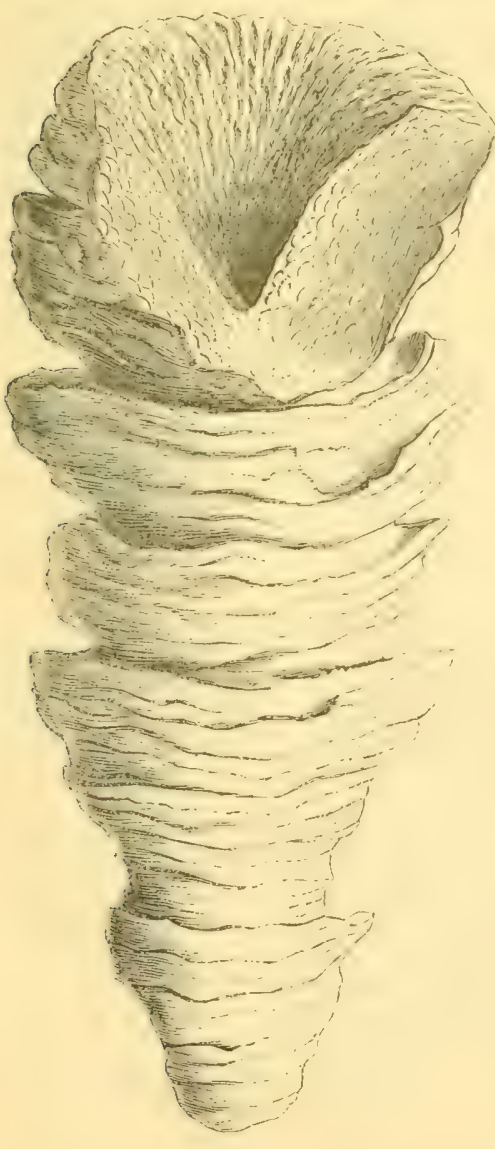

Fig. 8.

Cystiphyllum vesiculosum (Goldfuss) of the natural size, Hamilton Formation, Arkona. marked annulations of growth, which sometimes have the form of circular wrinkles, but which at other times are sharpedged and imbricating. Not uncommonly the folds of the epitheca are laterally prolonged in the form of wing-like extensions. Calice rery deep, its walls extraordinarily thickened in aged examples, and its bottom usually occupied by a group of bullae. Septal strix in the interior of the calice usually very distinct, but appearing tn be made up of a succession of elongated vesicles. Internal structure vesicular, the largest of the vesicles being central, and having a diameter of a line to a line and a half. Young individuals are truly simple, but older examples increase by calicular gemmation, a succession of vertically superimposed corallites being thus produced. In an individual of average size, the length is three inches, the diameter of the calice is an inch and a quarter, and the depth of the calice is an inch and a quarter. Large individuals occur, however, in which the length must have been between half-a-foot and a foot, whilst the diameter is nearly three inches.

Our specimens agree exactly with those figured by Goldfuss in his great work, and there cannot be the smallest doubt as to their identity. Our specimens show, also, in a most marked manner, a feature which is present in most of the examples figured by Goldfuss - viz., growth by means of calicular gemmation, just as has been already described in Heliophyllum Halli. In this peculiar mode of increase (fig. 8) the coral attains a certain growth, and the calice becomes then more or less obliterated by the extension over it of the epitheca. Then a new bud is thrown up from the calice, generally directly above the old one, and this too continues to gruw for a certain period. A third budis then produced in a similar manner, and a fourth, fifth, or sixth may be similarly produced, until the entire corallum may consist of a series of short turbinate cups, or inverted cones, superimposed one above 
the other, the younger upon the older. As the direction of the new cups does not always accord with that of the old ones, the general form produced by this mode of increase is often very peculiar and irregular. Some specimens also show extraordinary lateral prolongations of the epitheca.

In many respects, $C$. resiculosum resembles $C$. Senecaense and $C$. grande, but it is on an average larger than the former and smaller than the latter. It is also distinguished by its mode of increase, the disposition of its cells, its very deep calice, and its surfacc-characters. From C. Anericanum it is distinguished by its larger size, more turbinate form, larger calice, and wrinkled epitheca.

Loculity und Formution.-Rare in the Corniferous Limestone of Port Colborne and Hagersville. Very abundant in the Hamilton Formation of Bartlett's Mills, near Arkona, Township of Bosanquet.

\section{Cystiphyllom sulcatum (Billings).}

$$
\text { (Plate VI. Fig. 7). }
$$

\section{Cystipluyllum sulcatum (Billings), Cunudian Jourvial, New Series, Vol. IV. p. 136.}

"Corallum simple, short, turbinate, much curved, expanding at the rate of between forty and forty-five degrees from the minute sharp curved point upwards; cup oblique, the lower margin being on the side of the lesser curvature, moderately deep, and nearly regularly concave, the bottom covered with obscure coarse rounded radiating ridges; a shallow rounded groove or fossette extending from the centre to the higher margin, and in some specimens two others much less distinct, radiating to the sides at right angles to the main groove. Exterior encireled by obscure undulations, and lon ritudinally striated by the rudimentary radiating septa. The vesicular structure consists of irregular sub lenticular cells, from half a line to two lines in width; length of the convex side, from one inch and a half to three inches; the usual length appears to be about two inches or a little more; width of cup from one inch to one inch and a half; depth about half an inch" (Billings).

This pretty little species, in its external appearance, presents a close resemblance at first sight to small specimens of Ziy hirentis prolifica. (Billings,) from which, of course, its internal structure separates it at once. The epitheca is tolerably thick, and exhibits with unusual distinctness the vertical ridges which mark the position of the septa, along with numerous rounded annulations and folds of growth, these latter being sometimes obseure. C. sulicutum can readily be distinguished from all other species of the genus by its general form, its surfacecharasters, the great obliquity of the calice and the fossular furrow.

Lorality and Formation. - Corniferous Limestone, Rama's Farm, Port Colborne.

\section{Genus Mrcrocyclus (Meek and Worthen).}

"Corallum free or with a minute central point of attachment, discoidal, without columella; calice very shallow or nearly obsolete, and provided with a single small fossette; sept: short, nearly regularly radiating, or with a few of those nearest the fossette converging a little towards its sides; epitheca well developed.

"This little coral seems to be nearly related to C'unbophyllum and Buryphyllum, (Ed wards and Haime), but differs from the first in having a well-developed epitheca, and from the latter, not only in that character, but in having its fossette simple, and its costa nearly regularly radiating. It also presents similar differences from Hladroplyyllum of Edwards and Haime." (Meek and Worthen, Geology of Illinois, Vol. III. p. 420).

\section{Mrarocyclus Discus. (Meek and Worthen).}

Microcyclus iliscus. (Meek and Worthen,) Geol. of Illinois, Vol. III. p. 420, Pl. XI. Fig. 7, $a . b$.

"Corallum depressed-discoid; periphery sharp, under side flat, and protected by the concentrically-wrinkled epitheca; uppor side slightly convex, flat or a little concave in the middle; fossette-small, shallow, and extending from the centre to the margin. Septa very 
short, thick, and extending only about half-way in from the margin towards the middle (the central region being smooth). numbering from twenty to twenty-five at their inner ends, but each bifureating so as to double this number at the margin; sometimes the one ou the side opposite the fossette is divided into three." (Meek and Worthen, loc. cit.).
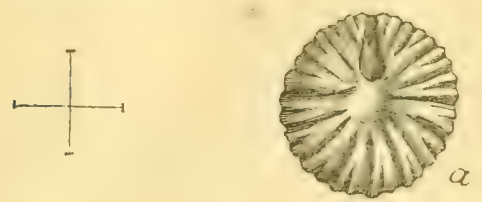

Fig. 9.

Micronclue discus (Mcek and Worthen); a upler surface, entareent. (The cruss shows the true dimensions); $b$ under surface of the same specimen, of the natural size.

the calice is at one point elevated into a small pointed boss.

Luculity und Formution.-. Rare, in the Hamilton formation, at Bartlett's Mills, ncar Arkona, 'Township of Bosanquet.

\section{Genus Haimeophyllum,(Billings).}

"Corallum agreregate, consisting of colonies of lone slender sul,-parallel corallites, united laterally by periodic expransions of the cup. Interual structure of vecicular diaphragms, as in the cente ITh linin: raliatine septa rulimentary" (Billines). The followiug species, from the Corniferous Limestone is at present the only one known.

\section{Haimeophyllum ordinatuar (Billings).} Fig. 29.

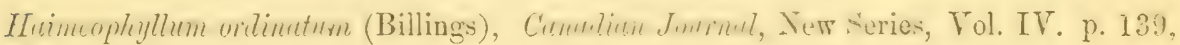

"Corallum forming larese. sub-elobular or flat hemispheric masses ; arerage dimeter of the corallites in the constrieted prortions one line and a hall to two lines, and of the expansinns two aml a half to three and a hialf lines. The epithexis. where it can be seen between the expansions, is more or less distinctly narked with the horizontal septul stria. There appears to be about forty internal stria. The expansions which enuneet the enrallites are periodical. or occur at the same level in all the individuals at clistances of from one to three lines" (Billings).

This remarkable coral cannot he confounded with any other. its peculiar mode of arowth appearing alone to be quite distinctive. The larerer masise appear to be formed of successive strata, the corallites of each stratum being usually short (holf an inch in height), and being superimposed upon those of the inferior stratial, not directly but alternately, so that the corallites of one stratum appear to spring from the periotic calicine expansions of the corallites in the stratum below. All examples, howerer, do not show this; and it is pos.ible that the spe. cimens exhibiting this peculiarity are referrible to a new species.

Lrmerlity an! Formativiz. - Corniferous Limestone of Port Colborne, Hagersville, and Lot 6, Con. 1, Wainfleet.

\section{Genus Syringopora (Goldfuss).}

Corallum aggregate, at first creeping, after the manner of Autopnru, then sending up numerous vertical, eylindrical corallites, which are usually flexuous and sub-parallel, and are connected together laterally by numerous transverse connecting mrocesses. Epitheca well dereloped ; septa, rudimentary ; tabulie, close-set and infundibuliform, or placed within one another like a series of funnels.

The characters of the genus Syringopora are very well marked, and as a rule there is bot the smallest difficulty in recogaising any example of this genus. If, howerer, the Sy,inimporit lecrutu, and is. nobilis of IIr. Billings are to be retained here, then the definition of the genus must be somewhat modified, since the corallites of the former species have the habit of 
a Diphyphyllum and are not connected by horizontal processes ; whilst the latter in its adult state seems to have entirely the habit of an Aulopora with the internal structure of Syringopora, but equally without connecting processes.

Five species of Syringopor have been recorded by Mr. Billings from the Corniferous Limestone of Western Ontario, all of which have come under my observation in the same formation.

\section{Syringopora nobilis (Billings).}

Syringopora nobilis (Billings), Canadian Journal, New Series, Vol, iv., p. 118.

Corallum, lax, spreading, increasing by the production of lateral buds.

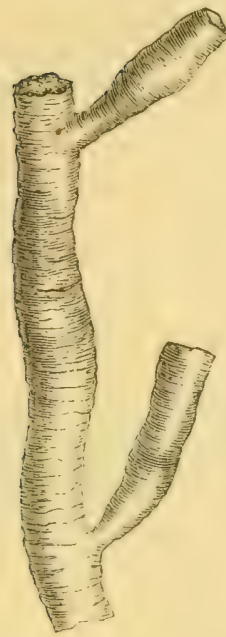

Fig. 10.

Syrringurar.a nobilis, (Billins), a fragment of the natural size. Corniferous Limestorle.

\section{Syringopora Hisingeri (Billings).}

Syringopora IIisingeri (Billings), Crundiun Journul, New Series, Vol. TV., p. 116.

"This species forms large masses of very long, nearly parallel or slightly viryius, slender corallites, which are closely aggregated, and present a rugeed or knobby appearance from the great number of the connecting tubes. The diameter of the corallites is one-third of a line, or a little more. The tubes of conuexion are distant from two-thirds of a line to one line and a half. The distance between the corallites is for the greater part less than their diameter. The young corallites branch from the sides of the adult individuals, and immediately become parallel with the parent, and connected with it again by the usual tubes of connexion." (Billings).

This elegant species is very readily recognized by the comparatively small size of the corallites, the closeness with which they are crowded together, and the great number of the connecting processes. It seems to me, however, somewhat que tionable if this species is really distinct from the preciously described $S$. Vurncuilli of the Devonian Rocks of Ohio, Milne Fdwards and Haime, Pol. Foss. des Teries Pelénoiques, p. 289.) The distinetion relied on by Mr. Billings in separating the two species is, that the corallites in S. Hisingeri are distant from one another for the most part by less than their own diameter; whereas in S. Ferneuilli they are distant twice or thrice their diameter. If this distinction could be shown to hold good in a larce number of examples of both forms, it would doubtless constitute a difference of specific value; but the distance between the corallites is not absolutely uniform in either, and it is therefore not improbable that the difference is one of variety only. In the meanwhile, however, it is safer to retain $S$. Hisingeri as a separate species, very easily distinguished from the other species of Syringopor a which have been detected in the Corniferous Limestone of Canada. Locality and Formation. - Not uncommon in the Corniferous Limestone of Port Colborne. 


\section{Syringopora perelegans (Billings).} fig. 19.

Syringopora perelegans (Billings,) Canadian Journal, New Series, Vol. IV., p. 117,

Corallites averaging about one line in diameter, straight or slightly flexuous, distant from one another their own diameter or a little more, connecting tubes horizontal or slightly oblique, varying in their distance apart, but usually from two to four lines distant on the same side of any given corallite; surface obscurely or deeply annulated.

This species is very closely allied to Syringopora reticuluta (Goldfuss), from the Carboniferous rocks of Europe, differing perhaps in nothing except that the connecting processes are not quite so closely set. It is also nearly related in many respects to S. Mluclurci (Billings), it being very difficult to decide with regard to certain specimens to which of the two forms they should be rightly referred.

Loculity und Fonmution. - Not uncommon in the Corniferous Limestone of Port Colborne, and very abundant at Lot 6 , Con. 1, Wainfleet; also in the Corniferous Limestone of Woodstock (Billings).

\section{Syringopora Maclurei (Billings).}

Syringopora tubipormides (Billings), ('un. Jumi., New Series. Vol. IV., p. 115, fig. 17. Syringopora Maclurci (Billings), Ibid. Vol. V., p. 258.

"This species is found in large masses of long slightly flexuous corallites. These have a diameter of about one line and a-half, and owing to their flexunsity, are at times in contact, and often two, three, or four lines apart. In lirce colonies which have grown luxuriantly without the interference of disturbing causes, the corallites are more regular than in the smitler or stunted sroups, in which the corallites are much bent and confused. The commecting processes are very short and distant, and appear to be sometimes mere inosculations of the stems. The corallites, after growing separately for a short distance, aynuroach each other and seem to grow together or adhere to each other for the srace of a line and a-lalf, or more; they then diverge and angain unite. There points of contact oceur at distances varying from three lines to six, nine, or even twelve lines. Fixternally they exhibit numerou. other indistinct annulations, and also faint indications of lon itudiual stria " (Billings: .

The most striking character which would separate S. Ifuluri from s. prevelemens is the diameter of the corallites, stated in the above de-eription as being one line and a-half in the former, whereas it is only a line in the latter. In a later paper (ćmudiun funt., New Sories, Vol.v., p. 25s) Mr. Billings, however, states that the widih of the corallites in S. Murturi is more generally only about a line, thus coming to agree in this character with s. pretegens. "The surfice characters of the corallites in the two specics are also the same. The chicf distinctions, therefore, between the two forms are to be found in the fitct, that the corallites of S. Mucluri are somewhat more robust on an average those of $s$. preleyuls, that they are at the same time more flexuous and hent, that they are not pleed at such uniform distances apart, and hliat the horizontal connecting procesies are not by any means a marked feiture, being delicate and separated by wide intervals, whilst the corallites often inosculate directly without the intervention of connecting processes at all. Many examples of s. Machuri are undoubtedly distinct from all other described forms, and the species may be regarded as being in many repects a connecting link between such an aberrant type as $S$. nolilis and the typical forms like S. pereleguns. Some specinens, howerer, occur which ean with difficulty be certainly referred to either $S$. Macluiei or $S$. pereleguns.

Loculity and Formation.- Not uncommon in the Corniferous Limestone of Ridgeway.

\section{Syringopora laxata (Billings).}

$$
\text { (Plate VI. Fig. 2.) }
$$

\section{Syringopora laxaiu (Billings), Cunadiun Journul, New Series, Vol. IV. p. 118.}

Corallites cylindrical, flexuous, sometimes geniculated. but not connected together by transverse processes. Fipitheca with numcrous encireling stria and annulations. Diameter of the corallites from one and a half to two lines, the distance between them being very variable.

In the absence of connecting processes, the present singular species differs from all the typical examples of the genus, and it seems doubtful whether it can be retained in Syringopora 
at all. The only traces of the connecting processes consist in occasional spiniform or tubercular projections of the epitheca, which do not, however, reach contiguous corallites. According to Mr. Billings, the distance between the corallites varies from three to eight lines ; but in all the specimens I have seen, the distance is less than this. In fict, owing to the flexuous course taken by the corallites, and more especially to their being by no means strictly parallel, their distance apart is very variable; and they are very often in contact for considerable distances. In the absence of septa and in possessing infundibuliform tabulæ, the present form agrees with the normal examples of Syringopora.

Lncality and Formation.--Rare in the Corniferous Limestone of Lot 6, Con. 1. Wainflect. Also at Woodstock (Billings).

\section{Genus Aulopora (Goldfuss).}

Corallum creeping, increasing by parietal gemmation ; the corallites pyriform, trumpetshaped, or cylindrical, the cavity of each communicating with that of the one from which it spring:. No tabula ; septa absent, or represented in a rudimentary form by longitudinal striæ, or rows of minute spines.

The corials of the genus A ulopora have often the closest resemblance to young colonies of Sypringopora, before the latter have commenced to throw up corallites vertically. There is thus reason to think that some of the deseribed species of Aulopora may be truly of the nature of immature examples of Syringopora, though others appear to be undoubtedly mature and distinct.

Mr. Billings has described three species of this genus, all peculiar to Canada, from the Corniferous Limestone of 'Western Ontario, and all of these have come under my notice. I have also to record specimens which appear to be in every respect undistinguishable from $A$, tubceformis (Goldfuss).

\section{AULOPORA FILIFORMIS (Billings).}

\section{Aulopora filiformis (Billings), Canadian Journal, New Series, Vol. IV. p. 119.}

Corallum fixed, creeping, forming somewhat confused groups, which adhere parasitically to forcicn bodies. Corallites about one-third of a line in diameter. Epitheca thick, with numerous fine encircling strix. Corallites usually budded forth at intervals of from one-third of a line to a line, sometimes further apart, their length being from half a line to a line and a-1half. Generally, the young corallites are produced in an alternating manner upon the two sides of the parent stem, but not uncommonly two, three, or four tubes maly be produced at a single point, and any individual corallite nay commence to throw out buds for itself. The tubes are often more or less bent, and their apertures are elevated above the surface upon which the coral grows.

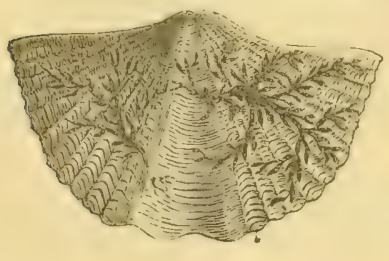

Q

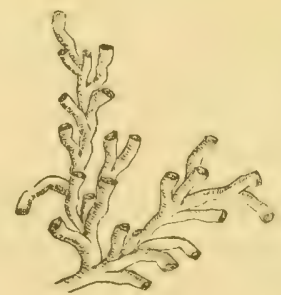

6
Fig. 11.

a. Anlopora filifomis (Billings), crrowing narasitically upon spirifere mueronceta. $b$. Portion of the same enlarged. Hamilton Formation, Arkona.

This beautiful little species is of common occurrence in the Hamilton formation, growing parasitically upon Spirifera mucronata, Cyrtina Hamiltonensis, Heliophyllum Halli, Cystiphyllum vesiculosum, the epitheca of species of Favosites, \&c. It is readily distinguished from the other species of the genus by the small size of the tubes, and also by its peculiar mode of growth. It is allied to Aulopora arachnoidea (Hall) of the Trenton Limestone, but is a larger form, and occurs in more reticulating and compressed groups.

\section{Loculity and Formatim. - Common in the Hamilton Formation of the Township of Bosan-}

* The fossil which I described under the name of Alecto? Canadensis (Canadian Naturalist, Vol. vil., No. 3), was founded upon casts obtained in the Corniferous Limestone. Having now obtained examples from the Hamilton group, ir which the actual fossil itself is preservet, 1 am disposed to resari this sirgular form as a somewhat anomalous $A$ ulopora. shall, therefore, describe it in the Appendix to this Report, under the name of Aulopora Canadensis. 


\section{AUlopora cornuta (Billings).}

Corallites tubular, trumpet-shaped, the diameter of their mouths being two lines, whilsi that of the parent stem is about one line. The corallites produced at intervals of from one to six lines. The epitheca thick and apparently smooth, and destitute of encircling stria.

I was at first disposed to doubt if this species were re:lly distinct from A. tulueformis of Goldfuss; but an examination of a considerable number of specimens has satisfied me that it is a good species. A. comnte is distinguished from A. tubeformis by the fact that the corallites are less crowded, and the diameter of the calice often is nearly or quite twice as great. In $A$. tubeformis the tubes seem to have a diameter at their mouths of about a line, judying, that is, from the figure of the species given by Goldfuss, who states no measurement. Some examples of $A$. cornute have the mouths of the tubes not more than cne line and a-half, or even less, across, and there thus remains the possibility that specimens may be obtained which will ultimately show $A$. cormutu to be ouly a large variety of $A$. tuberformis.

Lnculity cunl Hormution. - Rare in the Corniferous Limestone, Lot 6, Con 1, Wainfleet, and Port Colborne. Common in the Hamilton formation of the Township of Bosanquet; adhering to Brachiopods and Corals.

\section{Aulopora tubreformis (Goldfuss).}

(Plate VI. Fig. 3.)

\section{Aulopora tubceformis (Goldfuss), Petref. Germ. Pl, xxix. Fig. 2.}

Corallites tubular, more or less curved, expanding slightly towards the mouth. Diameter of the calice, one lins or a little more or less; the dianeter of the tube the same or a little le-s.

Whatever may be the value of $\alpha$. comutris as a distinct species, the Corniferous Lime. stone of Western Outario unquestionably yields examples of an Aulopricl. which caunot be

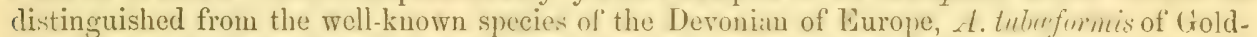
fuss. It is unfortunate that Goldfuss does not give any measurements; but accepting the accuracy of his figure (I'etrefakten, Pl. xxix. fig. '), the proportious and general form of our specimens-agree exactly with those of this species. T. have not seen any specimens in which the corallites are as crowded as they are in the upper portion of Gclitus's figure; but our specimens agree exactly with the portions of the same colony which appear on the right hand side and near the base of the figure in question; and, under any circumstances, the approximation of the corallites is very liable to vary in different portions of a colony of Aulopora. Upon the whole, therefore, I have no hesitation in identifying some of the exam. ples from the Corniferous Limestone with the Eifel species.

Locality anl Formution.--Not uncommon in the Corniferous Limestone of Port Colborne.

\section{Aulopora tMBellifera (Billings).}

\section{(Plate VI. Fig. 4.)}

Anlopore umbellifere (Billings), Cinculian Jourmul, New Series, V.1. Iv. p. 119, fig. 21.

Corallum growing in a lax and spreading manuer; the primary stems remaining undivided for a distance of a quarter or half an inch, and then giving origin to a cluster of corallites in an umbellate manner, some of these proliferating in a similar fishion, and at similar intervals. The number of corallites in a cluster varies from five or six to as many as ten or twelve, and though united at their point of origin they ultimately radiate more or less out. wards like the spokes of a wheel. The epitheca is thick, with encircling strix and annutions; the diameter of the corallites is about one line; and the septa are well represented by from six to ten rows of short spines.

This species is at once distinguished by its very peculiar mode of growth. As suggested by Mr. Billings, it seems questionable if it can be retained in the genus Auloporce, and it is quite probable that a new genus should be formed for its reception.

Locality und Formution. - Not very uncommon in the Corniferous Limestone of Port Colborne. Also in Lot 6, Con. 1, Wainfleet (Billings). 


\section{Genus Favosites (Lamarck).}

The genus Farosites (Lamarck), comprises branched or massive corals, composed of numer. ous more or less polygonal corallites, which are divided internally by transverse partitions or "tabulæ," sometimes quite rudimentary. The walls of the corallites are perforated by one, two, three, or more rows of "mural pores," by which the separate corallites are placed in communication. The septa are absent or rudimentary, being at most represented by tuber. cles or short spines.

The generic limits of Furosites have not been universally agreed upon by palæontologists, and the genera Emmonsia, (Edw. and H.), and Astrocerium (Hall), have been founded upon differences which Mr. Billings rightly regards as not of generic value. Thus, Emmonsia is distinguished from Favosites simply by the incompleteness of the tabulæ; but this same peculiarity can sometines be observed even in $F$. Gothlandica, the type-species of Favosites, individual examples of which not very uncommonly exhibit portions with the complete tabulæe of Facusites and other portions with the imperfect tabula of Emmonsia. In the same way, there are many examples of Furosites, of more than one species, in which the tabulæe, whether naturally or from some peculiarity in the manner in which they were preserved, are quite rudimentary and are even more imperfect than they are in ordinars specimens of Furosites hemispherica, ùpon which the genus Emmonsia was founded.

The genus Astrocerium, again, was founded by Hall (Pal. New York, Vol. 2, p. 120,) to include corals exceedingly like $F^{\prime} u$ cosites in all superficial characters, but differing in the possession of spiniform septa. It would appear, also, though this character is not specially mentioned, that $\mathrm{Hall}$ believed the corals which he referred to Astrocerium to be destitute of mural pores. This latter point, if it could be proved, would amply suffice to separate Astrocurium generically from Fitrosites; but there is much reason to think that the apparent absence of mural pores may be due to mineraliation merely. At any rate, it is far from uncommon to meet with examples of undoubted species of Furosites in which no pores can be detected. The other point-namely, the presence of spiviform septa-is also not a satisfactory distinetion, partly because some cxamples of Furnites exhibit the same thing, and partly because some examples which would generally be referred to Astrocerium from their geological position and general appearance, are without any traces of septa. Upon the whole, therefore, it would appear that the genera Astrocerium and Emmonsia can not be retained.

The numerous species of Fucosites may be divided into two groups, according as they are massive or ramose, $F$. Guthlandice being the type of the former, and $F$. polymorythe of the latter. The characters which have been relied on as separatiner the species of this genus are chiefly the following:-1. The diameter of the corallites; 2. The equality or inequality in size presented by the corallites ; 3 . The completeness or incompleteness of the tabula ; 4 . The number of rows of mural pores; 5 . The position of the mural pores, whether on the flat faces of the polygonal corallites or on their angles; 6 . The presence or absence of rudimentary septa. For convenience of reference the more important species of Furusites may be arranged as in the following table, it being remembered that some of the species here enumerated, are perhaps not valid, and the characters derived from the number of rows of mural pores are not constant, even in the limits of the same species:-

\section{A. Massive Species.}

(6. Tabula complete. One row of mural pores, placed on the faces of the corallites.

1. Favosites basaltica (Gold).

2. Favosites turbinata (Billings).

b. Tabula complete. Two rows of mural pores, placed on the faces of the corallites.

3. Favosites Gothlandica (lam).

4. Favosites Niagarensis (Hall).

c. Tabulæ complete. Three rows of mural pores, placed on the faces of the corallites.

5. Favosites multipore (Lonsd).

6. Favosites Troosti (Edwards and Haime).

d. Tabulæ complete. Mural pores situated in the angles formed by the prismatic walls . of the corallites.

8. Favosites aspera (D'Orb). 
c. Tabulx more or less incomplete. Mural pores in one, or more commonly in two rows.

9. Favosites hemispherica (Yandell and Shumard).

10. Favosites Forbesi (Edwards and Haime).

B. Ramose Species.

a. With one row of mural pores, on the faces of the corallites.

11. Favosites polymorpha (Gold).

12. Favosite: cervicornis (De Blainville).

13. Favosites reticulata (De Blainville).

b. Withone row of pores, placed in the angles formed by the prismatic ancles of the corallites.

14. Farosites fibrosa (Gold).

No less than ten species of f'ucnsites have been recognized as nceurring in the Devonian:

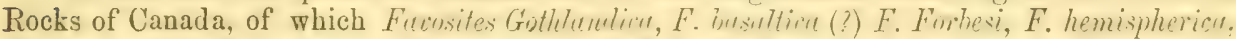
$F$. polymorpha, $F$. cervicomis, F. retirulute, and $F$. dullue are found in the same formation in Europe ; whilst $F$. turbinutu and $F$. Chummeni are as yet not known elsewhere.

\section{Favosites Gothlandica (Lamarck).}

Favosites Gothlandica (Lamarck), Hist. des Anim. sans Vert., vol, ii, p. 206.

C'ulcmopora Gothlundiu (Goldfuss), I'etref. G'rim., rol. i, p. is, plate xxri, figs. 3", 3b, $3 c$, and $3 e$. Goldfuss.

F'uvosites basaltica (Hisinger, Leth. Sinec, p. 96, 11. xxvii, fig. 5. Yot F. Gusultica of

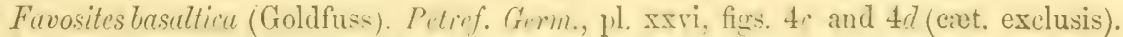

Favosites sub-basaltica (D’Orbigny), Prodr. de Paléont., vol. i, p. 49.

Favosites Gothlandica (McCoy), Brit. Pal. Foss., p. 20.

Favosites Goldfussi (D'Orbigny), Prodr. de Paléont., vol. i, p. 107.

Furosites Goldfussi (Milne Edwards and Haime), Pal. Fuss. des Terr. Pulénzuinues p. 235, pl. xx, fig. 3 ; and British Fossil Corals, pl. xlvii, figs. 3-3c.

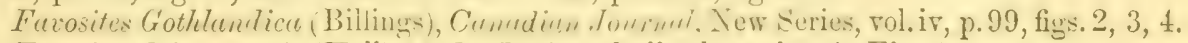

Favosites Niagarensis (Hall), Pal. N. Y., vol. ii, pl. xxxiv. A, Fig. 4.

(Many more references could be given, but the alowe are the most important).

The following is the diagnosis given by $11 \mathrm{r}$. Billings of this cosmopolitan species in the paper already referred to :- "Coratlum forming spleroidal, pyriform, or large hemispheric or flattened masses; coralliter in general betweu one line and one and a half' lines wide, sometimes less or more, often two lines; transwerse diaphragns usually complete, rarely incomplete; mural pores in nne, two, or three series, usually two, those of the same series about half a line distant, sometimes less; pores surrounded by an elevated margin; faces of the tubes with one or two longitudinal stria, more or less distinctly dereloped; radiating septa represented by a series of small spines, of t'n in the rudimentary form of tubercles."

The chief characters which may be relied upon as distinguishing typical examples of Favosites Guthlendice (Lam.), are the folluwing:-1. The corallites are of comparatively large size, usually about one and a halt lines in diameter, but varying from one to two lines. 2. The corallites are generally markedly polygonal, and are for the most part tolerably uniform in their dimeusions. 3. The mural pores are in two rows, placed alternately or sometimes oppositely on the faces of the corallites, and surrounded by elevated margins. 4. The tabules are complete, that is, extend from one sile of the theca to the other. 5. Perfect examples are usually of a more or less hemispheric or pyriform shape, and hare their lower surface enveloped in a thicker or thinner concentrically wrinkled epitheca.

Whilst the above charaeters are generally found to co exist in typical specimens of $F$. Gothluntica, there are, nerertheless, numerous departures from this state of things which must be attended to in studying this protean species:-

The size of the corallites in some specimens not otherwise separable from F. Gothlandica is sometimes uniformly below the arerage in an entire colony, not exceeding one line, or even a little less than this. This might not seem an important difference, but, as noticed by Ir. Billings, it gives the coral an apparently very distinet general appearance.

The corallites, though usually distinctly polygonal, are sometimes nearly round, through. out an entire colony; and their relative size in the same mass may vary to some extent. 
Thus, it is not uncommon to meet with colonies, in which the great majority of the corallites have a diameter one and a half lines, whilst some few have a diameter of a line or a little less.

Whilst the nural pores are usually in two rows, there is somelimes but a single row, and sometimes three rows; and single colonies may be found to combine all these variations in different corallites. It is probable that the typical forms upon which Goldfuss founcled his species $F$. basaltica, as believed by Lonsdale and $\mathrm{McCoy}$, are truly referrible to specimens of $F$. Gothlemelica, (Lam). in which but a single row of pores is present. F. Gollfussi Edwards and Haime, again seems unquestionably to be nothing more than a variety of $F$. Gothlandica as asserted by $\mathrm{Mr}$. Billings, the only distinctive characters brought forward by its authors being the unreliable ones that the rows of pores vary from one to three, and that they are more closely approximated than in typical examples of the latter. Iastly, the elevated ring which is often found surrounding the pores in $F$. Gothlandica, is in many cases absent, single specimens often exhibiting both conditions. It may be added that the pores themselves, eren in specimens otherwise well preserved, can by no means universally be detected.

The tabula are for the most part complete, extending from one side of the theen to the other; but this condition of parts is by no means constant. Specimens, otherwise well preserved, sometimes exhibit a complete absence of the tabulie. the corallites being hollow. Others exhibit a condition of things similar to what occurs in Fazosites Forbesi, though not so marked. The inner surfaces, namely, of the corallites, exhibit rudimentary and imperfect tabulie, in the form of little projecting lamella or ridges which project into the carity of the theca. Specimens exhibiting this peculiarity can usually be distinguished from examples of $F$. Forlesi, without difficulty, by the fact that the ridges representing the tabulae are not so closely set, are more delicate and plate like, usually run across the whole width of the corallite, and do not give to the interior of the theca the extraordinary roughness of appearance which is characteristic of $F$. Forbesi. In other specimens, again, the tabula have the characters which are distinctive of $F$. hemisyllericu, being closely set and incomplete, often more or less bent, and commonly interlocking. Such specimens, however, are readily separated from those which are rightly referred to $F$. hemisy herica, by the fact that in the former some of the corallites are always found to exhibit the complete tabulie of $F$. Guthlantice, whilst the size of the corallites is on the average much more considerable. In fact, the commonest condition in the specimens here alluded to, is that alternating jortinns of the mass exlitit it the complete tabula characteristic of $F$. Gothlantica, and the incomplete tabula characteristic of $F$. hemisphirira. Mr. Billings has also pointed out that the same corallite sometimes exhibits complete tabular in one portion of its course and incomplete tabulae in another.

As to the condition of the septa, the diagnosis of the species would, perhaps, be altered for the better by the statement that as a general rule the rejta are absent, or at any rate are nideterminable. They are, however, not uncommonly to be recognised in the form of small nierpalities or minute tubercles on the interior of the walls of the corallites; and they sometimes exist in the condition of distinct spines, though I have never noticed this state of things in any of the specimens fr $m$ the Corniferous Limestone. It is, however, not uncommon in Silurian specimens, and it has been observed and figured by Mr. Billings from Canadian examples found in the Corniferous.

Adult colonies of $F$. Gothluntiru usually have the form of much depressed pyriform masses, but great variations exist in this respect; and young colonies are usue lly spheroidal or simply pyriform, whilst the largest and oldest masses tend to assume the form of domeshaped or hemispheric masses. The colony is based upou a concentrically wrinkled epitheca, which is very commonly wanting in decorticated specimens, and attains a considerable thickness in aged examples.

Locality and Frmation.-Common throughout the Corniferous Limestone in Canada West, and also in the Hamilton formation.

\section{Favosites basaltica (Goldfuss).}

Calamopora basaltica (Goldfuss), Petref. Germ. Tl. XXVI. Figs. 4a, $4 d$.

Funsites basulticu; (Billings), Cunudiun Junrnul, New series, Vul. IV. p. 106, (in part).

It is with regard to this species that $I$ find myself compelled, though with great diffidence, to differ from the conclusions arrived at by Mr. Billings (C'unculian Jour. Vol. IV. p. 
106), more widely than as concerns any other form described by him. Having, howerer, had the opportunity of examining a very extensive series of specimens, I cannot at present accept his views with regard to the limits of this species. It seems pretty certain, to begin with, that the forms included by Goldfuss (Petref. Pl. XXVI. Figs, 4/(-l) under the name of $F$. litsictict differ from one another in their characters to such an extent that they would usually be (as they actually have been) separated into two distinet species. On the one hand, making the existenze of a single row of mural pores the distinguishing character of the species, Goldfuss includes under this head forms which differ only in this character from $F$. GotloIctulive; and on the other hand he associates with these forms which differ very widely from $F$. Grflilumlirm in most of their characters, but which are beliered to agree with the preceding in the above mentioned feature. We may, therefore. consider that F. lusulticu of Goldfuss was made originally to include the following two groups of specimens:

1. Specimens aeresine with $F$. Gothlumitira (Lam.), in possessing prismatic corallites, the size of which is upou the whole generally uniform. but which differ from $F$. Gothlemeline in possessing but a single row of mural pores. (Petref. Pl. XXVI., Figs. 4c, 4d).

2. Silecimens which agree with the preceding in hariug sometimes (not almays) a single row of pores, but which differ in having nearly rounded or cylindrical corallites, the sizes of which are exceclingly unequal; whilst the place of complete tabula is taken by numerous short projecting lamellae, which impart a peculiar and chatracteristic appearance to the iuner surface of the corallites. (Petref. Pl. XXVI., Figs. 4a, 4b).

Now, it is the first of these groups of specimens that palaenntologints have generally arreed in remarding as the tye-form of $1 \%$ lu...ltirn (Gold.); and the chief difference of opinion has simply concerned the question whether these forms are separable from F. Grithlentice (Lam.), or not. Some authorities. such as Mcl'oy d Lonsdale, naintain, apparently with god reason, that these forms are truly referrible to $F$. Grollemelicu; whilst others, such as Milne Edwards and Iname, retain these forms under a separate species under the nane of f. husultirn. Whichever of these views may be ultimately adopted. I. at any rate, have seen no specimens from the Cornifirous Jimentone of Westeru Ontario which aljicar to me to be truly reterrible to the type here alluded to. We do meet, certainly. with specimens exhihitiug prismatic basaltiform tubes, in every respect resembling $F$. Gothlumlicu, exeept that the corallites are on the average a little smaller, and they exhihit but a single row of mural pores. 'These specimens I wats at first sight dispoed to set down as belongine to $F$. lasslfiru, and I have seen them so named by ofhers I have, however, steceeded in fully satisfying myelf that the specimens in question are truly decorticated eximples of $F$. thithutu (Billings), in which there is also but a single row of pores. Examples of this species ean be found with the characteristic epitheea in all stiges and at all denrees of remoral; and when it has entirely disappeated, all the characters of this first section of $F$. lusullice (ciold.), are assumed, the only distinguishing mark, perhaps. being that the walls of the corallites have the comparatirely creat thickness which is characteristic of $F$. furlinetu. It need (mly be added in this comnection. that unmistakable examples of $F$. Guthlundien not uneommonly exhibit, as has been often noticed by other observers, the single rows of pores which Goldfuss believed to be character-

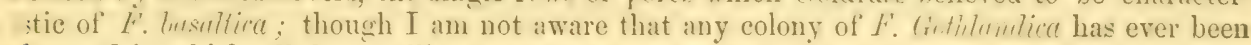
stserved in which all the corallites possessed but one row of mural pores.

We have now to consider the other group of specimens included by Goldfuss under the head of $F$. lusultiet, namely, those in which the corallites are more or less circular or cylindrial in shape, and are very unequal in size, whilst they possess other peculiarities as well. These specimens were separated from F. lecsulfied by Vilne Edwards \& Haime, under the Iame of Fursites Foll si: but they were subsequently re-united with the preceding sroup of forms by Mr. Billings, the name busultiru being retained for the combined groups. My own opinion, as I have already said, is that the colonies with small, nearly uniformly-sized. prismatic and uniporous corallites (as occuring in the Corniferous Limestone) are referable to decorticated examples of $F$. tmlimuta (Billings). I, therefore, am at present disposed to believe that Funsitus Fub si (Edw. \& Haime), is a good species, clearly separable firm the type-form of $F$. luteilticu, as cenerally accepted (though including part of $F$. Tuterlfirit of Goldfuss); and I shall describe under this name the second group of specimens to which I have drawn attention. 


\section{Fayusites Forbesi (Edw. \& Haime).}

\section{(Plate VII, Fig. 8 and Pl. VIII. Fig. 4.)}

Calamopora basaltica (Goldfuss), Petref. Germ. Pl. xxvi. Figs. $4 a$ and $4 b$. 238.

Favosites Forbesi (Milne Edwards and Haime), Pol. Foss des Terr. Paléoziques, p.

Favosites hasaltica (Billings), Canadian Joumal, New Series, Vol. iv. p. 106. (In part.)

Corallum forming spheroidal, pyriform, cylindroidal, or depressed hemispheric masses, composed of corallites which are generally circular or cylindrical in shape, and which are usually of very unequal sizes; mural pores usually in two alternating rows, rarely in a single row; tabulæe mostly rudimentary, and represented by very close-set projecting lamellæ, which roughen the interior of the corullites; radiating septa represented, sometimes clearly, sometimes indistinctly, by a number of longitudinal ridges or striæ.

The typical examples of this species are usually spheroidal, cylindroidal, or club-shaped, and possess almost perfectly cylindrical corallites. The corallites are large and small, each larger one being surrounded by a ring of smaller. The larger corallites are uniformly about a line and a half or a line and three quarters in diameter; but the smaller corallites vary considerably in size, from an eighth of a line up to about a line. The mural pores often cannot be made out, but in all the specimens I have seen there are constantly two rows of pores on the larger corallites, thus differing materially from $F$. basaltica (Gold.). Mr. Billings, however, states that the smaller tubes possess but a single row of mural pores. The condition of the tabula is exceedingly peculiar, and I do not thiuk it can be due, as suggested by Mr. Billings, to the manner in which fossilisation was effected; since it is constantly present in all our Canadian examples of this species, whilst these occur side by side with examples of $F$. Gothlandica in which the tabulie are complete. Exactly the same condition of the tabulae is shown also in one of the figures of $F$. Forbesi given by Milne Edwards and Haime, and drawn from a specimen from the Upper Silurian Rocks of England. (Brit. Fossil Corals. Pl. 60. fig. 2. f). The tabulæ, namely, are present in an incomplete and rudimentary form, being represented by numerous close-set lamelli, ridges, or short spines, which project a short way into the interior of the corallite, giving it a most peculiar and easily recognised appearance. The most perfectly preserved specimen in my possession, in which the tubes are filled up, instead of being as usual hollow, exhibits tabulae which are slightly more developed than those just described, approximating closely to what is observable in $F$. hemisy herica. The tabulse, namely, in this speeimen are close-set, thin. flexuous lamelle. which for the most part extend about half-way across the corallite, often bifureating or interlecking at their free ends; but which, in some instances, actually become complete, and pass right across the corallite. The radiating septa are quite rudimentary, and, when discernible at all, have the form of obscurelymaked longitudinal striæ. Lastly, I have observed in several sperimens, especially in those of a cylindroidal or clavate form, the peculiar feature that the calices of a greater or smaller moiety of the colony are closed by an epitheca, closely resembling what is observed in $F$. turbinate (Billings).

Mr. Billings has shown that small specimens, having the characters above mentioned, pass by a perfect transition into much larger pyriform specimens, which present the peculiurity that the corallites at the base of the mass are large and unequal in size, whilst those at the summit are on the average smaller, and are nearly equal in size. The same eminent palaontologist has also pointed out that the younger pyriform colonies also pass, by an equally perfect transition into elongated cylindrical forms, often of considerable length. Both these statements I am enabled to confirm from my own observation.

Besides the typical examples of $F$. Forbesi which I have just described, there occur not uncommonly others which I cannot at present separate from this species, though they present several more or less well marked peculiarities. 'The corallum in the examples in question resembles in shape the more ordinary individuals of $F$. Gothlendica, being circular and flattened above, and springing from a pointed and attenuated base, which was doubtless enclosed in an epitheca. The corallites are not distinctly circular, but are cylindruidal or sub-prismatic, and they are nearly equal in size, having an average width of one line. Interspersed, however, with the ordinary corallites are some smaller ones having a diameter of half a line or a little less. The mural pores appear to form a double series. The radiating septa are well marked 
and form a series of about twelve strong ridges which run longitudinally in the interior of the corallites. These septal ridges are erossed by rudimentary trbala in the form of short spinelike lamellæ, about three or four in the space of a line, and not placed on the same level in contiguous ridges. It is possible that these forms are specifically distinct from those which I have here referred to, $F$. Forlysi ; but I do not feel that it is safe to sepurate them at present, Locality und Formution.-Corniferous Limestone, Port Colborne, and Lot 6, Concessinn 1, Wainfleet.

\section{Favosites hemispherioa (Yandell and Shumard).}

\section{(Plate VIII. Fig. 3.)}

Farosites hemispherica (Yandell and Shumard), Contrib, to Geol. of Kentucky, p. 7. Alveolites hemispherica (D'Orbigny), Prodr. de Paléont, Vol. I., p. 49.

Emmonsia hemispherica (Milne Edwards and Jules Haime), Pol. Foss, des Terr. Paléoz, p. 247 ; and Brit. Fossil Corals, Plate XLVIII., figs. 4, $4 a$. $5,6,7$.

Fevosites hemisphurice (Billings) Canadian Journal, New Series, Vol. IV., p. 105, figs,

In its essential characters this species is very closely allied to $F$. Guthlemetire. Externally; however, it may in general be distinguished from the latter by the much smaller size of the corallites, which are usually only from one twenty-fourth to one twentieth of an inch in diameter, though they sometimes reach one line. Internally, the species is distinguished by the fiact that the tabulie are incomplete, very thin and closely set, usually exteoding only alunut half way across the corallite, and often interlocked toward- its centre. Some of the tabula. however, are usually complete. The mural pores are stated to be in one, two, or three row: (Nilne Edwards and IIaime, and Billing:) but I have not suceeded in detecting their arrangement in any of the Canadian examples which have eome under my own notice. According to Milne Edwards and Haime, also. there are twelve well dereloped septa, but these are indeterminable in the Canadian specimens. This species may posibly turn out, as suggested by Mr. Billings, to be identical with $F$. Grullumblire, but its distinctive characters can usually be recognised with such ease as to justify placing it under a separate specific title. There can be no hesitation, however, in following Mr. Billings in his refusal to adopt the genus Emmonsin, proposed by Fdwards and Haime to recive this species, and founded simply unm the incomplete condition of the tabula.

Incelity und Formutim.-Common in the Corniferous Limestone of Ridgeway, Port Colborne, and many other localities in Westeru ()ntario. Also, in tho IIamilton Formation of Bosanquet.

\section{Favosites turbinata (Billings).}

\section{(Plate VIII. Figs. 1 and 2.)}

Fucnsites furlinutu (Billings), Canadian Journal, New Series, Vol. IV., p. 109, and Tol, V., p. 258, fig. 7 .

"Corallum forming elongate turbinate masses. sometimes two feet in length and six inches in diameter, often curved at the base. Corallites nearly of an uniform size, usually: somewhat less than a line in width; trausverse diaphragms thin, flat, flexuous, complete or incomplete. Only one row of pores has been observed. Whole surface except the upper part covered with a stronge epitheca which closes the mouths of the cells" (Billirgs).

There can be no question as to the specific distinctuess of this most remarkable species, the most singular representative of the genus. The form of the colony varies much, but is in typical specimens that of a straight or curred cone, which varies in length from less than one inch up to two feet. Other examples are more or less cylindrical, either straight like Orthoceratites, or more commonly curved or twisted, and of irregular diameter. Other specimens, again are irregular curved masses, which look like large potatoes.

In perfectly preserved specimens, the whole of the colony, except the upper surface, is covered by a thinner or thicker epitheca, which seals up the calices of the corallites. The summit of the colony is usually somewhat cup-shaped (though this may not be a natural appearance); and it is only here that the corallites are open. In most specimens, the epitheca 
is smooth, and is sufficiently thin to allow of the walls of the corallites to be distinctly traced through it. In such cases, the mouth or calice of the corallites appears to be closed with a kind of disc, which is sometimes level with the general surface, often depressed slightly below it, and sometimes elevated in the form of a rounded boss.

In a very large number of specimens, the epitheca has been more or less denuded over parts where it originally existed. In such cases, it is mostly only the epitheca which has been removed, and the corallites are left intact and uninjured, with their calices quite empty. In other cases, the epitheca bas been entirely decorticated, whilst the corallites may remain uninjured, or may be more or less broken away towards their outer ends. Such specimens can in general be readily recognized by the general shape of the colony and the peculiar characters of the corallites. In other cases, lastly, the epitheca is sufficiently thick to render the calices of the corallites below, obscure or invisible. In these instances, concentric lines of growth are usually exhibited by the epitheca, and these are sometimes developerl into such strong and irregular annulations as to simulate pretty closely the appearance of perfect specimens of Clisiophyllum Oneidaense (Billings).

The corallites radiate from the imaginary axis of the colony, either in straight lines or curves; and the size of the mass in the turbinate specimens increases rapidly by the interstitial addition of fresh corallites. In shape the corallites are rounded, sub-prismatic, or, more commonly, distinctly prismatic. In size they are by no means uniform, there being generally a considerable number of under-sized corallites intercalated amongst the nearly equal-sized larger tubes. The larger corallites have most commonly a diameter of from a line to a tenth of an inch, whilst the smaller ones may be half a line or less in width.

The tabula are commonly complete, sometimes incomplete, and are about three or four in the space of a line.

The mural pores, so far as I have observed, are uniformly in single rows, placed on the flat surfaces of the corallites, not surrounded by an elevated border, and of comparatively large size. Their distance apart is most commonly about half a line, but is sometimes as much as a line.

The walls of the corallites are of unusual thickness, in the great majority of cases; and they are not undistinguishably fused with those of contiguous corallites. Hence the lines of division between the walls of neighbouring tubes can be plainly seen in parts from which the epitheea has been removed, or even through the epitheca when the latter is of no great thickness.

Completely decorticated specimens might very readily be referred to one of the two groups of forms usually placed in $F$. basalticu (Gold.); the group, namely, comprising forms with prismatic corallites of small size, with but a single row of cells. Specimens, again, exhibiting longitudinal sections, but not exhibiting the outer surface, would also, almost certainly, be referred to $F$. basultica. In the former case, the thickness of the walls of the corallites, and their leing generally quite distinct and not fused with one another, would usually suffice for their determination. In the latter case, a positive determination would probably be impossi ble, unless some portion of the outer surface could be observed.

Loculity and Formation.-Common in the Corniferous Limestone of Ridgeway, Port Colborne, and other localities in Western Ontario. Also in the Hamilton Formation of the Township of Bosanquet.

\section{Favosites polymorpha (Goldfuss).}

\section{(Plate VII. Fig. 7.)}

Calcmopora polymorylia (Goldfuss), Petref. Germ. Plate XXVIJ. figs. 2b, 2c. 2d, 3b, 3e cæt. exclusis).

Corallum sub-massive or dendroid, often dichotomously branched, or reticulated; diameter of branches varying from a little over a line to more than an inch. Corallites radiatin. in all directions from an imaginary axis, nearly at right angles or obliquely, more or less contracted internally and widening as they approach the surface. Liameter of corallites from half to three-quarter's of a line in branches of half an inch across, often with smaller ones intercalated. Calices in reality more or less polygonal, but often rendered circular by the thickening of their walls. Mural pores in single series. 
The above would stand as a general definition for a number of branching species of Furosites, which some eminent palmontologists, such as Lonsdale, McCoy and Billings, regard as belonging to a single natural group; whilst other high authorities as De Blainville, and Milne Edwards and Haime, distribute them amongst several species. My own view would coincide with the former of these-namely, that the forms in question should be regarded as belonging to a single very variable specific type, the Farosites polymorphe of Goldfuss. As this view, however, has not been universally accepted by the leading authorities on the subject, I shall describe the branching forms of Furosites which occur in the Corniferous Limestone of Western Ontario, under the names of $F$. polymorpha, $F$. reticulutu, $F$. dubia, and $F$. cervicormis. To these I have to add an allied but apparently distinct and undescribed form, which I shall designate by the name of $F$. Chapmani, and which appears to be in some respects intermediate between the genera Favosites and Alveolites.

Taking this view of the subject, Fatosites polymorplla proper will be restricted to such forms as are more or less massive or lobate, thus constituting a transition between the truly massive species and the regularly dendroid types such as $F$. retirulutu and $F$. duliu. The calices are polygonal, of unequal sizes, there being small ones intercalated amongst the larger. The diameter of the larger calices is generally about two-thirts of a line; and their walls are not particularly thick.

As thus restricted, $F$. pulymurphu can not be said to be of common occurrence in the Corniferous Limestone of Western Canada; and I have met with comparatively few specimen. which would conform with the figures given by Goldfuss in his great work. (Petrefueten. Plate XXVII. Figs $2 b, 2(, 2 l, 3 l$ and $3 c$.) This is the more singular, as the regularly branched forms which constitute $F$. reticulctu and $F$. duhice, are of exceeding common occurrence.

Locelity and Formution.-Corniferous Limestone of Port Colborne and Ridgeway.

\section{Favosites reticulata (De Blainville).}

\section{(Plate VII. Fig. 2).}

('alcemopore spongites (var. remose) (Goldfuss), Petref. Germ. Plato XXVIII. Figs. $2 a-2 g$, (cæt, exclusis).

Alveolites reticulata (De Blainville), Dict. Vol. LX. p. 369.

Farosites Orbignyanre (De Verneuil and Jules IIaime), Bull. Suc. Géol. de France, 2nd series, Vol. VII. p. 162.

Facosites reticulutu (Milne Edwards and Jules Haime), I'ol. Fus's des Terr. Palécr. p. 241. ; and Brit. Foss. Corals, p. 215, Plate XLVIII. Fig. 1, $1 b$.

Corallum dendroid, branched, the branches inoseulating and reticulated in most instances, diameter of the branches a line and a half to two lines, calices nearly equal, circular or nearly so, with very thick walls, their diameter about half a line or a little less (counting in the thickness of the wall).

This form is distinguished by its branched and usually reticulate form, and its equal or sub-equal ealices, which open on the surface with hardly any obliquity. Ridgeway.

Locality and Formation. - Abundant in the Corniferous Limestone of Port Colborne and

\section{Favosites dubia (De Blainville).}

\section{Plate VII, Fig. 5.}

('alemopor polymorqlau (var. aracilis) (Goldfuss), Petref. Germ. Plate XXVII, fig. 5. Alveolites dubia (De Blainville), Dict. Vol. LX, p. 370.

Favosites dubia (Edwards and Haime), Pol. Foss. des Terr. Paléos., p. 243,; and Brit. Foss. Corals, p. 216.

This species is very closely allied to $F$. reticulatu, from which it is unsatisfactorily distinguished by the fact that the branches do not coalesce and inosculate, and by the inequality in the size of the corallites, a few very smull calices being intercalated amongst 
the larger ones. The diameter of the larger calices is from half a line to two thirds of a line. The calices are more or less rounded, and their walls thick. The diameter of the branches is mostly from three to four lines.

In some specimens, in place of there being a few minute corallites interspersed amongst a great number of larger-sized ones, the corallites are only moderately unequal, and the number of small ones is about equal to that of the large ones.

A considerable number of examples, again, occur, which do not appear to be separable from the preceding, but in which the dimensions are decidedly smaller, the branches being only from one and a half lines to two lines in diameter, and the width of the calices being from one third of a line to half a line. Ridgeway.

Locality and Formation. - Abundant in the Corniferous Limestone of Port Colborne and

\section{Favosites cervicornis (De Blainville).}

Caltunoporce polymorphn (var. remoso-divaricate) (Goldfuss), Petref. Germ., Pl. XXVII, figs. $3 a, 4 a, 4 b, 4 c$ (cret exclusis).

Alveolites cervicornis (De Blainville), Dict., Vol. LX, p. 369.

Farosites cervicornis (Milne Edwards and Haime), Pol Foss. des Terr. Paléor, p. 243 ; and Brit Foss. Corals, p. 216, Pl. XLVIII, fig, 2.

Favosites polymorpha (McCoy), Brit Pal. Foss., p. 68.

Favosites cervicornis (Billings), Cunadim Journal, New Series, Vol. IV, p. 110, fig. 9.

Corallum forming lobate or branched masses, the divisions of which are usually thick, blunt and irregular. The corallites oblique to the axis of the branches, unequal in point of size, with thin walls. The calices unequally sized, rounded or polygonal, about a line in diameter, sometimes less.

$F$. cervicornis differs from $F$. polymorplen in its more branched and antler-like form, the much greater obliquity of the corallites, and the thinner walls of the calices; but it is questionable if there exists any difference of specific value. Mr. Billings mentions that he has specimens which agree well with those figured by Goldfuss (Petrefucten, PI. XXVII, figs. $3 a, 4 a, 4 b, 4 c)$; and I have also several examples which appear to belong to the same form. The Farosites cristatc of Edwards and Haime appears to be founded upon examples of $F$. cervicomis, in which the calices are somewhat below the average. in width.

Loculity and Formation. - Rare in the Corniferous Limestone of Lot 6, Con. 1, Wainfleet, Ridgeway, and Port Colborne.

\section{Favosites Chapmani (Nicholson).}

\section{(Plate VII, Fig. 6.)}

Corallum branching, apparently not reticulated, the diameter of the branches being from two to four lines. Corallites exceedingly oblique, forming a very acute angle with the axis of the branch, slightly unequal in point of size. Calices rounded or transversely oval, very oblique, but not triangular when perfect. The internal wall of the corallite is prolonged along the next corallite above, whilst the external or lower wall is truncated; so that whilst the corallite is oblique in its course, the opening of the calice is parallel with the surface. The diameter of the calices varies from half a line to one line. The wall is comparatively thin.

This species is distinguished from all others known to me by the extremely small angle which the corallites make with the axis of the branch, and by the extraordinary obliquity of the calice. In this last respect $F$. Chupmani makes a near approach to the genus Alveolites, lout the aperture of the calice is not triangular, unless worn down, the walls of the corallites are quite thin, and there are no traces of septal teeth. The species to which $F$. Chapmani approaches most closely is $F$. cervicomis (De Blainville). Our form, however, is ramose and composed of eylindrical branches, instead of being lobate and divided into obtuse finger-like processes ; whilst the aperture of the calice is considerably more oblique. Indeed, $F$. Chapmani not only resembles Alveolites in the obliquity of the calice, but also in the fact (as regards the more typical nembers of the latter genus) that the exterior wall of each 
corallite is free for a certain space, and is not overlapped by the corallite below, whereas iu Fuvosites the walls of the corallites are contiguous throughout, and are nowhere free. I have dedicated the species to my distinguished colleague, Professor E. J. Chapman.

Lonality and Formation.-Not uncommon in the Corniferous Limestone of Port Colborne, and Lot 6, Con. 1, Wainfleet.

\section{Genus Alveolites (Lamarck).}

Corallum dendroid, massive, or encrusting; composed of short, prismatic or cylindrical corallites, with inseparably united walls, often arranged in superimposed coneentric layers. Tabula complete. Nural pores few in number. Calices oblique to the surface, sub-triangular or erescentic, the lower lip most prominent. Septa absent, or represented by from one to three vertical toothlike projections.

The geuus Alweolites is very nearly allied to Finosites, but is distinguished by the much greater shortness of the corallites, the common presence of one or more toothlike ridges representing the septa, and the oblique calice with its sub-triangular, crescentic, or semi-circular aperture and prominent lower lip. In the obliquity of the calice, howerer, Frevosites Chaymumi closely approaches Aleolites. From Chertes and Stemopore, again, the genus Alewolites is distinguished by the possession of nural pores, and, as a general rule, by the much greater thickness of the walls of the corallites. As in the genus Frtesits the species of Alievlite. may be divided into massive and ramose forms; but some of the former are truly encrusting. and simply become massive by the superposition with advancing age of successive concentric layers of corallites.

Mr. Billings records two species of Alienlites as oceuring in the Corniferous Limestone of Western Ontario, and four species from the Hamilton formation of the same region. All of these except 1 . squemense, have come under my notice, and two of the Hamilton species (viz. A. Remeri, and A. Fisterii) I have also detected in the Corniferous. I have likewise to add five species from the Corniferous Limestone, which appear to be altogether new, together with a single undescribed form from the Hamilton group.

\section{Alveolites labiosa (Billings).}

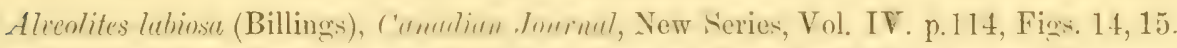

Corallum ramose, or sometimes sulp palmate, the stems eylindrical or sub-cylindrical, branching at intervals of from a yuarter of an iuch to half an inch, generally at angles of from $60^{\prime \prime}$ to $70^{\circ}$, but not anastomosine or forming network Diameter of the stems firom a litt e over a line to two lines. Corallites oblique, oval or sub-triangular, with a projecting lower lip. Calices transversely oval, or triangular when worn, with the apex of the triangle directed downwards. Calices distant from one another from a third to half a line measured vertically, and from a fourth of a line to a third of a line measured diagonally or transverscly. Longest diameter of the calices, when unworn, about a fourth or a fifth of a line.
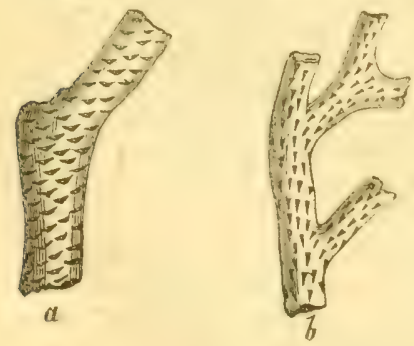

Fig. 12 .

Sections of this species present a close resembles to Alveolites vermicularis (McCoy), (see Milne Edwards and Haime, British Fossil Corals, Plate 48, Fig. 5), but the branching takes place at more acute angles in the present form, no interlacing of the stems seems to occur, and the corallites, though somewhat curved, are not flexuous. In one specimen which may perhaps be a variety of $A$. labiosa, the interior of each corallite exhibits on the upper wall, on one side, a single strong septal ridge, dividing the a. Fragment of Alveolites eryptodens, (Billings); natural size. b.
Frayment of Alveolites labiosa, (Billings): natural size. ci. Frag- calice vertically into two communicatine
ments of Alveolites conferta, (Nicholson); natural size. All from the Corniferous Limestone.

compartments.

Locality and Formation.-Abundant everywhere in the Corniferous limestone of Westeru Ontario. 


\section{Alveolites Remeri (Billings).}

\section{Alveolites Roemeri (Billings), Canadian Journal, New Series, Vol. v., p. 255.}

Corallum ramose, of cylindrical, sometimes sub-palmate, branched stems, from one and a half to three lines in diameter. Calices transversely oval, about half a line in width, and nne fourth of a line in length, usually distant from one another about half a line measured in the longitudinal direction of the stem, and one fourth of a line in the transverse direction.

In some examples, as noticed by Mr. Billings, the calices are more closely set than as above stated, but this point is certainly not of specific value. The only two forms with which A. Pameri could casily be confounded, are A. lubiosu (Billings), and A. cryptodens (Billings). From the former of these it is distinguished by the trausversely-elongated oval form of the calices, and their comparatively great width, the cells of A. lubiosa being markedly triangular and not having a width of more than a quarter of a line. In A. cryptotens, on the other hand, the calices are more of a triangular shape than in A. lifemeri, and they are much more distant and remote. Mr. Billings describes A. liemeri from specimens obtained in the Hamilton formation, but examples also occur not very rarely in the Corniferous Limestone.

Locality aml Formation.-Corniferous Limestone of Port Colborne. Abundant in the Hamilton group at Bartlett's Mills, near Arkona, 'Township of Bosanquet.

\section{Alveolites oryptodens (Billings).}

Alveolites cryptodens (Billings), Canudian Journul, New Series, Vul. IV., p. 115, fig. 16.

Corallum dendroid, the branches cylindrical, or sub-cylindrical, from two to three lines in diameter, not inosculating or forming a network. Corallites oblique, the calices transversely oval, or sub-triangular, arranged in spiral or sub-spiral lines. The calices possess prominent lower lips, and usually open in an obliquely and not directly transverse direction as regards the axis of the branch. The long dianueter of the calices is about half a line. Calices distant less than a line measured either transversely or diagonally, and about a line measured vertically. "Two small tooth-like ridges occupy the inner surfice on the side towards the exterior, apparently half a line from the mouth or lower lip of the cell" (Billings).

The characteristic tooth-like septal ridges of this species are only rarely preserved, and I have never seen them; but specimens with the proportions mentioned by IIr. Billings are by no means very uncommon. Apart from this character, the species (Fig. 12, $a$,) is readily distinguished by the ramose but not reticulated corallum, the large size and obliquity of the transversely oval culices, and their comparative remoteness from one another.

Locality and. Formation.-Corniferous Limestone of Port Colborne and Ridgeway.

\section{Alveolites conferta (Nicholson).}

Alveolites conferta (Nicholson), Geological Magazine, Feb., 1874.

Corallum ramose, composed of cylindrical or elliptical branching stems, which bifurcate, but do not interlace. Diameter of the stems from two to three lines. Corallites minute, oblique to the surface, opening by calices which are arranged in irregular diagonal lines, and have a circular, or transversely oval, hardly sub-triangular shape. Calices oblique, minute, and excessively crowded, about one-sixth to one-eighth of a line in their longest diameter, and separated by intervals of from one-fifth to one-fourth of a line transversely, or the same distance, or less, measured vertically. There are, thus, from three to four calices, and from two to three interspaces in the space of one line, measured either diagonally across a branch or vertically (Fig. 12, c).

This species is allied to the preceding in its general configuration, but it appears to be decidedly distinct from these or from any previously described forms. It is distinguished by its very minute and extremely close-set corallites, and by the fact that the calices are, as a rule, not distinctly sub-triangular, and have not a markedly prominent lower lip. In some respects, $A$. confertu has the aspect of a $C^{\prime}\left(e^{\prime}\right.$ intes, especially in the fact that the corallites appear at first sight, to be surrounded by a copious cœenenchyma. This appearance, however, is leceptive, and I have no doubt as to the correct reference of the species to Alveolites. borne.

Loculity and Farmation.-Rare in the Corniferous Limestone of Ridgeway and Port Col- 


\section{Alveolites (Cenites?) Distans (Nicholson).}

Alreolites (Ccenites?) distans, (Nicholson), Geologieal Magazine, Feb., 1874.

Corallum ramose, the branches cylindrical, of a diameter of from a line and a half • two lines, dividing dichotomously at intervals of about half an inch, but not antstomosinz. Corallites oblique to the surface, with excecdingly thick walls. Calices exceedingly minute, about one-eighth of a line in their longest diameter, sub-circular, transrersely oval. or sub. triangular, lerel with the surface, and having the lower lip hardly or not at all prominent. Tntervals between the calices proportionately rery wide-about half a line. (Fig. 13.)

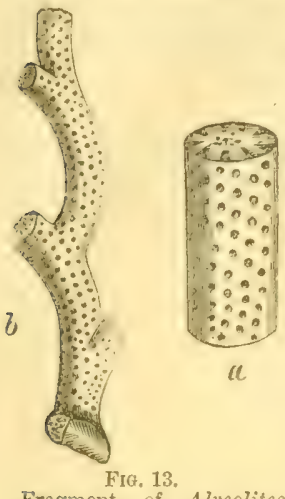

Fragment of Alveolites distens (Nicholson), natural size, $\boldsymbol{a}$ Portion of the same enlarged. Corniferous.

At first sight, this remarkable species has very much the appearance of a Canites (such as C. intertextus) or of the uncertain form Alvealites (?) seriatoporoides (Edw. and H.) It is, bowerer, distinguished from the former by the not prominent and not markedly triangular calices, and from the latter (which is almost certainly not an Alveolites) by the fact that the corallites are arranged obliquely to the surface.

Alveolites distans is readily distinguished from the other ramose forms of the genus by the exceedingly small size of the calices, and the proportionately great width of the intervals between them, and by the fact that the calices are level with the general surface, or nearly so. There is thus produced the fallacious appearance that the corallites are imbedded in an abundant coenenchyma.

Lurulity uml Frimution.- Rare in the Corniferuns limestone of Port Colborne.

\section{Alveolites Rajulosa (Nicholson).}

\section{(Plate VII. Fig. 3.)}

\section{Alveolites ramulosa (Nicholson), Geological Magazine, Feb., 1874.}

Corallum reticulated, composed of flattened sub-cylindrical or cylindrieal stems from twothirds of a line to one and a half lines in diameter, branching with great frequener, and interlacing to form a close network, the meshes of which vary from on to two lines in diameter. Corallites very minute, about three in the space of a line measured diagonally, the ealices very small, oval or triangular, separated by intervals of rather more than a third of a line, and about a sixth to an eighth of a line in their longest diameter (Fig. 14, $a$ and $b$ ).

This species represents in the genus flirulites, the anastomsing $F$. ritiruinte in the genus Funsites. It is distinguished from . l. luhinst, with which it is structurally most closely allied, not only by the reticulated form of the corallum, but also by the much more minute corallites. It differs from A. cunf, lin in forming a network, in the corallites being more remote, and in the fact that the calices are distinctly sub-triangular or eren triangular, as a general rule.

Loenlity and Formution. - Not very uncommon in the Cornifurous Limestone of Port Colborne, and Lot 6, Con. 1. Wainfleet.

\section{Alveolites Billingsi (Nicholson).}

\section{(Plate VII. Fig. 1.)}

\section{Alveolites Billingsi, (Nicholson), Geological Magazine, Feb., 1874.}

Corallum reticulated, composed of cylindrical or sub cylindrical stem; from two to three lines in dianneter, which branch dichotomously, for the most part at ansles of about 4()$^{\circ}$, and anastomose to form an open network, the meshes of which are oval or diamon l-sh uped, and vary in length from three lines to three quarters of an inch. As in the preceding species, the network is not always in a single plane, and the branches often coalesce at the nodes of the 
network to form flattened sub-palmate expansions. Corallites small, crowded, with thin walls ; the calices sub-triangular, or, when worn, markedly triangular, with the point of the triangle directed downwards; about three in the space of one line measured either diagonally or vertically. The long diameter of the calices is about one-fourth of a line, and the interspaces between them are about half as much. (Fig. 14, b.)
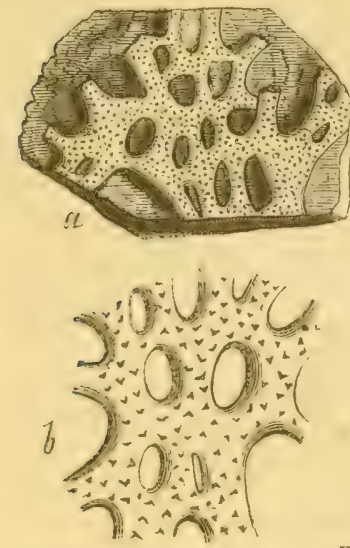

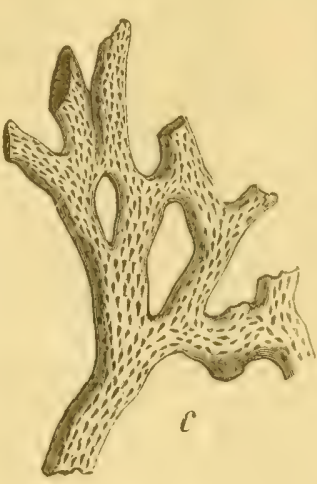

FIG, 14.

a Fragment of Alveolites ramulosa (Nich.), of the natural size, Portion of the same, enlarged. $c$ Fragment of Alveolites Billingsi (Nich.), of the natural size. Corniferous Limestone.
A. Billingsi is allied to A. ramulosa, but is distinguished by the larger size of the stems, the dichotomous mode of division, the more open network, and the larger size of the corallites. From A. labiosa it is distinguished by its reticulated form and closer corallites.

Locality and Formation.-Not very rare in the Corniferous Limestone of Port Colborne and Lot 6, Con. 1, Wainfleet.

\section{Alveolites Selifynit (Nicholson).}

\section{(Plate VII. Fig. 4.)}

\section{Alveolites Selwynii (Nicholson), Geological Magazine, Jan., 1874.}

Corallum forming an irregularly shaped erust or depressed mass about a line in thickness. The corallites are extremely oblique to the surface, and open by calices which have the form of curved or lunate slits, the length of which is about three quarters of a line, whilst their wilth is only about a tenth of a line in the centre. The calices are placed in irregularly alternating rows, or sometimes in an indistinctly sub-spiral manner, and are about half a line or three quarters of a line apart.

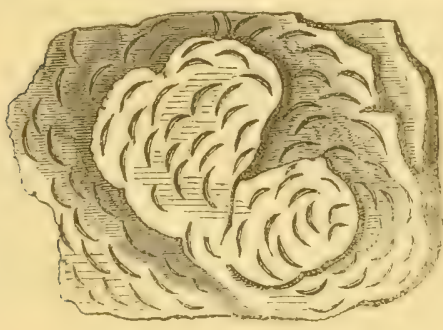

Fig. 15.

'This curious form belongs to the same section of Alveolites as A. sub-orbrcularis, (Lam.) A. Goldfussi, (Billings), and $A$. depressu (Edwards and Haime). It is distinguished by the remote, curved, fissure-like calices, with nearly parallel walls, and by the absence of any distinct concentric arrangement of the corallites. In the shape of the calices it somewhat resembles Conites labrosus (Edwards and Haime), but it, is in reality totally different both in its general form and in its real structure.

I have only seen a single example of the species. A tragment of the upper surface of the Alveo-It is dedicated to $\mathrm{Alfred} \mathrm{R.} \mathrm{C.} \mathrm{Selwyn,} \mathrm{Esq.,} \mathrm{F.} \mathrm{G.} \mathrm{S.,}$ lites Selwynii_(Nich)., enlarged. Cofniferous Lime- the Director of the Geological Survey of Canada.
stone.

Locality and Formation.-Corniferous Limestone, Port Colborne.

\section{Alveolites Goldfussi (Billings).?}

Alveolites Goldfussi (Billings), Canadian Joumal, New Series, Vol. V. p. 255, Fig. 5.

Corallum forming irregular undulated expansions, or depressed discoidal masses, sereral inches in width and from two lines up to two inches in thickness. Under surface covered with a thin concentrically-wrinkled epitheca, similar in every respect to that of a Favosites. 
The epitheca carries in young cxamples one, and in aged examples many layers of corallites. which are arranged in a radiating nianner round the central point of the coral, and which open very obliquely on the surface. 'The calices are of large size, in general from three-fourths of a line to oue line across, and half a line in heiwht. Their shape is usually transrersely oval, or three-sided, the outer side being curved, and the two inner sidesstraight. Owing to the thin ness of the walls of the corallites, the calices clo not appear to be separated by any interspaces transversely, but overlap one auother. There are no traces of teeth or groores on the interior of the corallite.

Alculites Gullfussi is nearly related to three European species, viz., A. sultimliculeri. (Lam.) A. Lenheri (Edwards and Haime), and A. Gruni (Edwards and Haime), the first from the Devonian formation, and the two last from the Tpper Silurian Rocks. From the first of these the present species is separated by the slightly larger dimensions of the corallites, and by the fact that the calices are destitute of the groore and corresponding process or ridec which are such a marked feature in the former. Alwhlits Lulwhiri, again, has decidedly smaller corallites, and the calices have an internal process, similar to that of $A$. suldorbiculurio. though not so prominent.

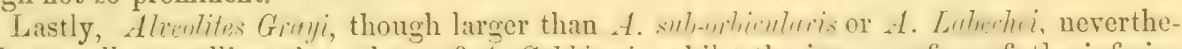
less hats smaller corallites than those of $A$. Gollt fusi ; whilst the inner surface of the inferior calicinal edge carries a distinct elevated process. As regards the species of Aliwtites known in the Devonian Rocks of North America, A. Cruldfus is ton distinct to render any confusion possible.

Lerelity and Formution.-Abundant, and attaining a larce size, in the Hamilton formation of Bartlett's Mills, near Arkona, Tornship of Bosanquet.

\section{Alveolites Fischeri (Billings').}

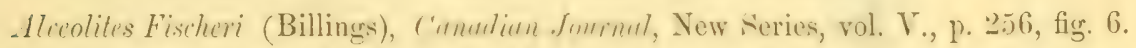

Corallum in the form of a flattened, palmate or undulating expansion, which appears to have grown in an erect position from a strong root-stalk, and which is celluliferous on both sides. Size of the entire corillum unknown, but certainly laree, fragments of sereral square inches in area being apparently not uncommon. Thickness from less than one line to four lines; corallites obligue to the surfaee, the calices being transversely oval ou the whole, usually with one curved and two straight sides, sometimes diamond-shaped, with four straight sides. In typical examples the calices have a long diameter of about half a line (sometimes more: and a short diameter of about a fourth of a line; and they are separated by intervals of about half a line or less, measured either vertically or transversely across the froml. The interior of the calice exhibits no internal process or ridge.

Aceording to Mr. Billings, the caliecs in this species are "distant firm each other about two thirds of a line in the rertical, and a little less in the transvere direction of the frond." I have, however, scen no examples in which the calices are so remote as this: and I can oniy suppose that Mr. Billings must have taken his measurements from older and larger specimenthan any which have come under my observation.

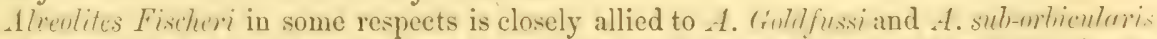
but it differs in its general form altogether, since it is celluliferous on both of its sides; instead of having the corallites opening on the upper surface, whilst the under surface is covered ly an epitheca. It is also distinguished by the proportions of its corallites, which are uniformly

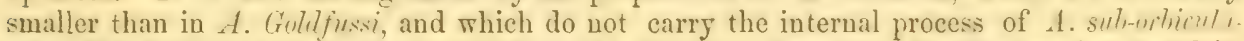
i.: Mr. Billings records the species from the Hamilton formation, but I have also found it, though rarely, in the Corniferous Limestone.

Loneclity and Formution.-Corniferous Limestone of Port Colborne. Hamilton formation. Bartlett's Mills, near Arkona, Township of Bosanquet.

\section{Alveolites frondosa (Nicholson).}

Alveolites frondosa (Nicholson), Geological Magazine, Feb., 1874.

Corallum forming elongated, sometimes palmate expansions, which appear to have grown in an erect position from a rooted base, and which are celluliferous on the two sides. 
The width of these expansions appears never to have been over an inch and a quarter, often less, and the thickness rarely exceeds two lines, but the height is unknown, and certainly exceeded two inches in some (probably in many) cases. The corallites spring from the median plane of the frond on both sides, are very oblique to the surface, and have very thick walls. The ealices are small, transversely oval, or sub-triangular, arranged in oblique lines, their long diameter being not more than from one-fourth to one-third of a line, with a transverse diameter one-half less. The inferior lip of the calice is thin and prominent, but there are no traces of any internal ridge or tooth. The calices are separated by intervals of about one-third of a line in the vertical direction of the frond, and one-fourth of a line or less in the transverse direction of the frond. There can be no question as to the entire distinctness of this not

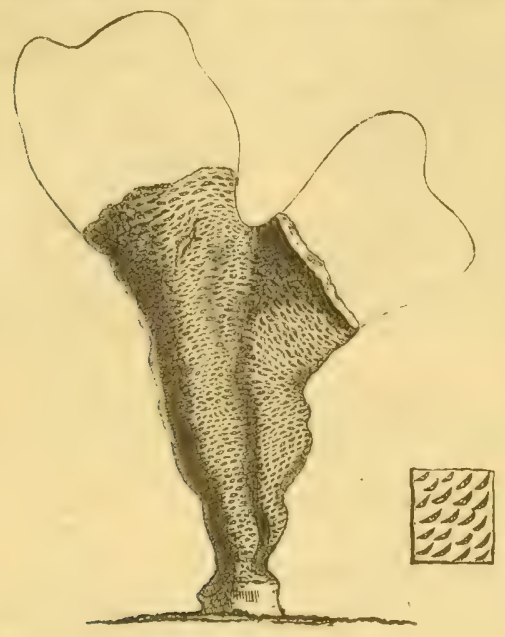

Fig: 16.

Portion of the frund of Alealites fromlosa [Nicholson]. a Fragment of the same magnified, Frum the Hamilton formation.

line in width. One of the specimens examined each, where spots, one-fourth of an inch wide central ridge on one side of the coll in this pecies, a there are obscure indications of a ings, Can. Jour., New Ser., Vol. V., p. 257.)

From the above description, it is obvious that $A$. squamosa belongs to the same natural group of Alrcolites as A. Gollfussi, A. sub-onticuluris A. Lulvechei, and A. Grayi. On the other hand $A$. frondose agrees with $A$. Fischeri in the fact that the corallum had the form of a flattened expansion, which was attached below to some foreign object by a strong foot-stalk, and which carried the corallites on both sides. Whilst agreeing in this respect with $A$. Fischeri, the present species is nevertheless readily distinguished by the dimensions of the corallites.

Locality and Formation.-Common in the Hamilton Formation at Bartlett's Mills, near Arkona, in the Township of Bosanquet.

\section{Genus Striátopora (Hall).}

"Ramose, coralla solid ; stems composed of angular cells ; apertures of cells opening upon the surface into expanded angular cup-like depressions ; interior of the cell rayed or striated; stria extending beyond the aperture of the cell." (Hall, Pal. New York, Vol. II. p. 156).

As regards the typical species of this genus, viz. : S. flexuosa (Hall), from the Niagara group, some doubt has obtained as to its Cœelenterate character, and it has been referred to the class of the Polyzoc. There is, however, no doubt as to its being a true coral. One species of the genus, viz. : S. Limenen (Billings) has been recnrded from the Devonian Rocks of Canada, and the close relationship between this and the ramose species of Furosites is obvious. Professor Hall has also recorded a species of the genus from the Hamilton group of Iowa, (viz. : Striatopora rugosa, Hall, Geology of Iowa, Vol. I., Part 2, p. 479, Plate I. Fig. 6), 
though it would appear that this is really identical with the previously described $S$.(Cyathopuru) Invensis of Dale Owen. Lastly a species of the genus has been recorded by Messrs. Meek \& Worthen, from the Lower Helderberg group of Missouri, under the name of S. Arissonitivis (Geology of Illinois, Vol. III. p.- 369, Plate VII. Fig. 4).

\section{Striatopora Linneana (Billings).}

Striutopnna Linneana (Billings), Cunutimn Jumrunl, New Series, Tol. V. p. 253, Fig. 1.

"Stems, two or three lines in diameter, branching at an angle of $75^{\circ}$ to 80 ; cells rariahle in size, the greater number with the expanded mouth one line wide, and the circular carity at the bottom from one-third to onc-half of a line: the smaller or younger cells, of all sizes, are somewhat uniformly distributed amongst the larger. In the perfect specimens the mouths of the cells are everywhere in contact with each other, the edges of the walls between them sharp, and the form more or less polygonal, senerally five or six-sided. In worn specimens the cells are more nearly circular, and the walls obtusely rounded on the edge. The stria in the cell-mouths not observed" (Billings, loc. cit. p. 253).

This species is by no means of common occurrence. The fer examples which exhibit the internal contracted aperture at the bottom of the expanded calice, can be determined with ease ; but those in which these apertures are concealed, can hardly be separated from a small undetermined Farosites which abounds in the same beds. The foritsits in question oceurs in the form of small sub-cylindrical, irregularly lobed, or sub-palmate masses, generally from an inch to an inch and a half in height, the corallites being unequally sized, polygonal, and thinwalled. The difficulty is still further increased by the fact that strimtopmon Limmene dues not appear to possess the radiating strix which are so characteristic of the grenus.

Lorality und Formution.- Lare in the Hamilton Formation of Bartlett's Mills, near Arkona, Township of Bosanquet.

\section{Genus Trachypora (Edwards and Haime).}

"Corallum dendroid, the branches presenting calices which are nnly slightly salient, and in which there are uo radiatiug septa ; cœnenchyma very alsundant, solid, and with the surfice marked by strong irregular, vermicular, and sub-echinulated strix." (Edrards and Haime, Pol. Foss. des Terr. Paléoz. p. 305).

M. M. Edwards and Haime have described one species of this genus ('T. Lhridsmin) from the Devonian liocks of Europe, and Mr. Billings has recorded another (T. deyfentula) from the Hamilton group of Ontario.

\section{Trachypora elegantula (Billings).}

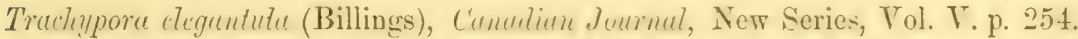

Corallum solid, ramose; the stems from one and a half to two lines in diameter, branching at an angle of $75^{\circ}$. Corallites arranged in four or five rows, parallel with the direction of the axis of the branch. Calices excavated in the conenchyma, oval, about two-thirds of a line in their long or rertical diameter, and half a line in their short or transverse diameter. The calices are surrounded by a prominent margin, and are usually separated by intervals of about half a line. Not uncommonly an extra corallite is intercalated between the regular. vertical rows. The surface of the counenchyma is ornamented with slightly flexuous broken strix, four or five of which occupy the space of one line.

This elegant species is readily distinguished from the only other known form of the genus (viz., T. Ilucidsoni) by its cells arranged in a linear series, and its non-echinulate strix.

Locality and. Formation.-Hamilton Formation of Bartlett's Mills, near Arkona. Township of Bosanquet.

\section{Genus СнжтетEs (Fischer).}

Corallum ramose, massive, or incrusting, composed of elongated basaltiform corallites, which are in close contact, and are not united by auy conenchyma. Tabule well dereloped; septa absent; no mural pores. 
The genus Chectetes is nearly allied to Farosites, but is separated by the absence of mural pores. Very similar in all essential respects to Chetetes is the genus Stenopora, of Lonsdale, the differential character of which is stated to be the presence of minute styliform processes at the angles of the calices. Good authorities, however, reject the genus Stenopora aitogether, and refer the forms placed here partly to Furosites and partly to Chetetes. Lastly, the genus Monticulipora has been founded by D'Orbigny to include species of Chretetes which increase by gemmation, instead of fissiparously, as is ordinarily the case in the genus.

In the present state of our knowledge, it seems almost impossible to separate these three genera; or, at any rate, it is certainly often impossible, after the most careful examination and comparison, to decide positively to which one of them a given specimen belongs. In the Hamilton Formation of Western Ontario occur three small corals which are certainly referable to one or other of these three genera, and which I shall provisionally consider as belonging to the genus Chutetes. All three I have been unable to identify with previously deseribed forms; and I have, therefore, been compelled, though with great reluctance, to consider them as new.

\section{Chretetes moniliformis (Nicholson).}

\section{Chotetes moniliformis (Nicholson), Geological Magazine, Feb., 1874.}

Corallum ramose, the branches having a diameter of from three to five lines. Corallites polygonal, with thin walls, for the most part nearly equal in size, but having a few very small ones intercalated amongst the larger ones. The surface exhibits rounded eminences ("mamelons") placed at distances of rather more than a line, over which the calices are larger than in the intervals between them. About four calices in the space of one line. At each of the angles of each calice is a minute nodular thickening, which gives a peculiar beaded appearance to the surface, but which is not prolonged inwards into the interior of the corallite in the form of a spine. On the contrary, well preserved specimens show that these bead-like or moniliform thickenings of the angles of the calices are continued above the general surface in the form of short, blunt spines, which communicate to the coral a roughness readily perceptible to the touch.

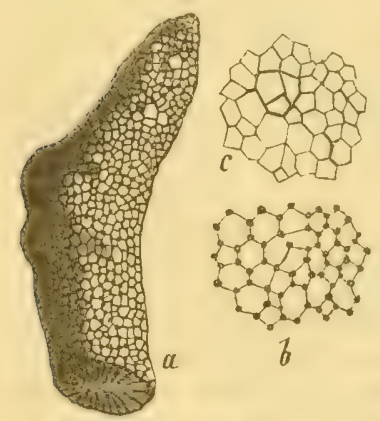

Fig. 17.

a. Fragnent of Chetetes inomiliformix (Nuch.), enlareded ; $b$. a purtion of the surface of the same, still further enlarged; $c$. a prortion of the suriace of ChrptetesBarrandi (Nich.), ireatly colarged. From the Hamilton group.

Lorulity and Formation. quet.

\section{Chatetes Barrandi (Nicholson).}

\section{Chotetes Barrandi (Nicholson), Geological Magazine, Feb., 1874.}

Corallum ramose, or forming small lobate masses, with a diameter of from two to five lines. Corallites polygonal, nearly equal, though with some smaller ones intercalated amongst the larger ones, with thin walls. The surface does not exhibit distinct eminences, but here 
and there are groups of corallites, slightly larger than the ordinary ones, and separated by intervals of about a line and a half. From four to five calices in the space of one line.

This species is very closely allied to $C$. Goldfussi ( $\mathrm{Edw}$. and H.), but is distiuguished by the fact that the calices are markedly polygonal, instead of being circular or oval, and that they are sub-equal, with very few smaller ones interspersed amongst them, whereas, in the latter species, there are intercalated amongst the ordinary calices a number of exceedingly minute ones. From the well-kuown Clintetes tumitus of the Carboniferous rocks, again, the present species is distinguished by the polygonal shape of the calices, their thin walls, and their much larger size, the corallites of the former being thick-walled and nearly circular. and there being about eight of them in the space of a line.

Loculity and formutim. -. Tot uncommon in the Hamilton group, at Widder, Township of Bosanquet.

\section{Chetetes quadrangularis (Nicholson).}

Choetetes quadrangularis (Nicholson), Geological Magazine, Feb., 1874.

Corallum forming thin crusts of from one-tenth to one-sixth of a line in thickness Corallites suh-equal, with very thin walls. about eight in the spatce of one line, for the most part polygonal, but often quadrangular in shape. The surface is smooth, and destitute of eminences, nor are there groups of larger corallites regularly intersjersed amongst the smaller ones.

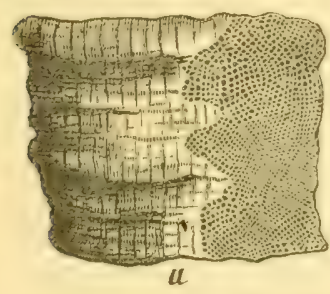

Fig. 18.

P. Portion of the crust of Chotetes quadrangularis, (Nich.), cruwin: ujun II limplullum II alli, slishtly enlarged; $b$. a few cells of the same greatly enlarged. From the Hamilton group.

This species is found commonly encrusting Heliophyllum Halli, and often forming expansions of considerable extent, but apparentiy never composed of more than one layer of corallites. It is distinguished from $C$. tuberculatus ( $\mathrm{Edw}$. and $\mathrm{H}_{\text {.) }}$ by the smaller size of the corallites, the absence of distinct eminen ces or gibbosities of the surface ("mamelons,") and the very commonly quadrangular form of the calices.

Locality and formation.- Not uncommon in the Hamilton group of Bartlett's Mills, near Arkona, Towuship of Bosanyuet.

\section{Genus Callopora (Hall).}

Corallum compound, massive, encrustine. or ramose, the corallites minute, tubular. separated by a still more minutely tubular conenehyma. 'The exenenehymil always reudered resicular by transverse diaphragms, and the corallites also usually tabulate. Septa rudimentary or absent.

The genus C'ulloporn includes a number of corals. which range from the L'pper Silurian (Niagara group) to the Devonian, and which, in some instances. have decidedly the aspect of Polyzom. The affinities of the genus are, however, beyoud all question, so far at any rate, as the sprecies which have come under my observation are concerned. Cullopiru, beyond all doubt, is a genus of Tabulate corals, and finds its nearest allies in the genera Heplintites and Fistulipore. From the former of these, C'allopere is separated by the absence of septa, and from the latter by the fact that the tubuli of the conenchyma are regularly tabulate. whilst the corallites themselves have the theea either open, or partitioned off by few remote horizontal tabulæ.

One large species, which perhaps may subsequently be found to admit of subdivision into two, has occurred to me in the Corniferous Iimestone and IIamilton Formation of Wetern Ontario, and this is very clearly distinct from all previously recorded forms.

\section{Callopora incrassata (Nicholson).}

Callopora incrassata (Nicholson), Geological Magazine, Jan.y 1874.

Corallum sometimes encrusting foreign bodies, sometimes forming large expansions, or sometimes constituting large hemispheric masses which are composed of numerous concentric 
layers, superimposed one upon the other. Corallites very minute, tubular, their circular calices slightly elevated above the general surface, and surrounded by a prominent margin. From three to five calices in the space of one line, separated by intervals of from half to twothirds of their own width. Corallites, sometimes with the theca undivided, but more commonly partitioned off by a few remotely placed horizontal tabule. Coenenchyma composed of exceedingly minute tubuli, which are partitioned off by numerous close-set horizontal diaphrugms. No traces of septa. The surface exhibits at intervals of about two lines elongated, star-shaped spaces, sometimes smcoth, sometimes punctate or minutely pitted, which are not penetrated by tubes of any kind, and appear to be quite solid. There are generally from three to six corallites surrounding these vacant spaces, which are larger than the others; and the .ppaces themselves have a long diameter of about a line or more, by a shorter diameter of half a line. In some specimens, also, the surface exhibits occasional large conical elevations pierced cach by a single canal, the diameter of which is about a line, and which descends vertically into the mass.

The characters of Cellopore ineressuta are most remarkable, and I am not satisfied that two closely related species have not been included under the above description. That we have
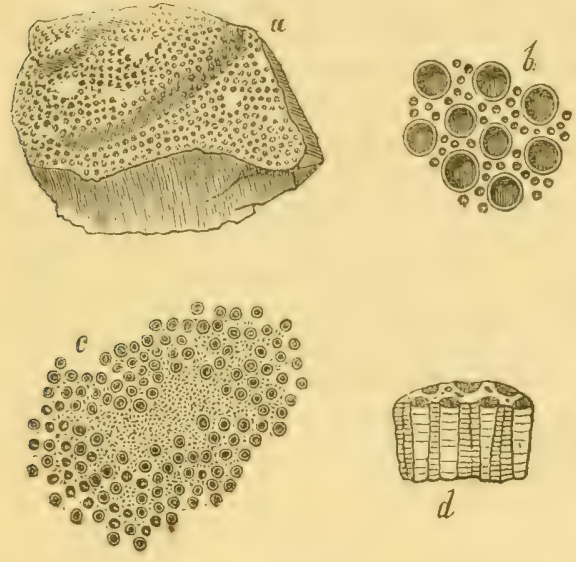

Fig. 19. to deal here with a Tabulate coral allied to Fistulipora or Heliolites is sufficiently clear ; but there are many anomalous points presented by the fossil. The specimens which I have included under this head occur in at least three forms. Some of them form thin crusts upon Heliophyllum Halli or Cystiphyllum vesiculosum, themselves in turn supporting the tubes of Ortonic or Spirorbis, or the creeping stolons of Aulopora. Others form flattened or undulating expansions, and others appear as irregular or hemispheric masses, varying from an inch in diameter or less, up to the size of a man's head, and composed of numerous concentric layers. The majority of examples exhibit the extraordinary clear spaces on the surface, which are neither penetrated by the corallites nor by the tubuli of the cœnenchyma. These spaces are usually elongated, and often somewhat depressed below the

Callopora incrassata, (wiki). a. A frament, natural general surface, and prolongations extend from

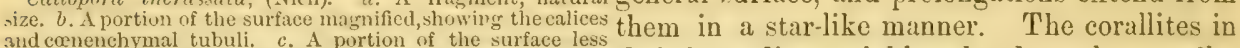
and conenchymal tubuli. c. A portion of the surface less them in a star-like manner.
lighly nagnified showing a vaeant space surrounded by coral- their immediate neighbourhood are also usually, lites. $d$. Vertical section of a fragment enlarged. From the some or all, larger than the ordinary ones. Only a few specimens exhibit the large conical elevations perforated by large vertical canals : but in those that do, these structures appear to belong properly to the fossil, and not to be extraneous. In other minor respects the fossils differ very considerably amongst themselves. The specimens from the Corniferous Limestone are mostly of large size, the corallites are of comparatively small size, the intervals ocupied by the coenenchyma are proportionately wider, and the fact that the coenenchyma is composed of minute tubuli can not be determined. I feel. however, pretty sure that these peculiarities are simply to be ascribed to the method in which the specimens from this formation have been fossilised. In the specimens from the Hamilton formation, again, the peculiar vacant spaces are not always recognisable, and appear to be certainly absent in some instances over areas of considerable extent. Most of the Hamilton specimens show very clearly the tubular nature of the cenenchyma, but there is a good deal of difference as to the amount of conenchyma. Some examples have the corallites separated by intervals of nearly their own width, the interspaces being filled with circular or polygonal tubules. Others, on the other hand, have the corallites nearly in contact, with but a single row of excecdingly minute tubuli separating them. An epitheca, so far as I have seen, i: only occisionally present, and the flattened expansions often sarry corallites on both sides.

Loculity and Formution.--Corniferous Limestone of Port Colborne, and more abundantly in the same formation at Hagersville. Common in the Hamilton formation at Widder, and also at Bartlett's Mills, near Arkoni, in the Townships of Bosanquet and South Williams. 


\section{Genus Fistulipora (McCoy).}

-Corallum enerusting or forming large masses, composed of long, simple, cylindrical, thichwalled tubes, the mouths of which open as simple, equal, circular, smooth-edged cells on the surfice, and have numerous transverse diaphragms at varial,le distances; intervals between the tubes oceupipl by a cellular network of small vesicular plates, or capillary tubules traversed by diaphragms." (Brit. Pal. Fos.. p. 11). The genus Fistulipure presents close affinities to the genus IIcliolite and also to Cinlonmin. From the former, Fistulipure is distinguished by the fact that the corallites are destitute of septa, whilst it differs from the latter genus in the finct that the conenchyma is regularly tubular, and that both the corallites and the intervening tubuli are traversed by numerous and regular tabula.

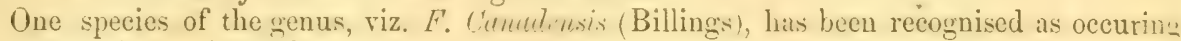
in the Devonian rocks of Canada.

\section{Fistulipora Canadensis (Billings).}

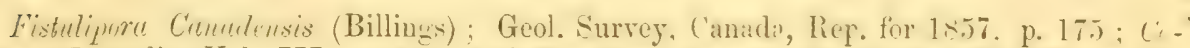

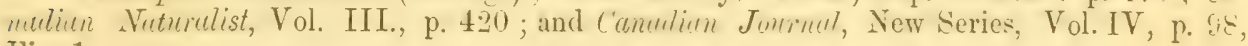
Fig. 1.

Corallum forming irregular masses, or, more commonly, large undulating crusts or expansions, from half an inch to an inch or more in thichness. Uuder surfice covered with a thin conecntrically-wriukled epitheca. Corallites perfectly eylindrical, from at third of a line to half a liue in diameter, usually about half a line distant from one another, sometimes one line or more, their mouths slightly projecting above the general surface. ('ounenehyma composed of minute, polygonal or sub-circular tubuli, of which from two to four occupy the space of one line. The number of tubuli separating the various corallites varies from a single row up) to three or four rows. Both the corallites and the intermediate tubuli of the conenchyma exhibit numerous close-set and well developed tabula.

Fistulipma C'unulensis occurs very abundantly in both the Corniferous Limestone and the Hamilton formation of Western Ontario; and though there are some slinht differences between the examples from these two formations, these differences do not appear to be of spe-

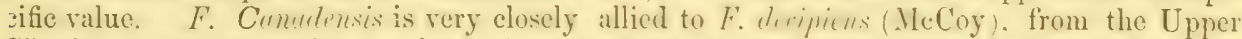
Silurian Rocks, the chief or only distinction of importance being that the tubuli of the cocnenchyma are considerably larger in the former than they are in the latter.

Lnculity and Formution. - Common in the Corniforous Limestone of Port Colborne. Ridgeway, Hagersville, ․e. Also in the Hamiltou formation at Bartletts's Mills, near Arkona, Township of Bosanquet.

\section{Genus Mranelinia (De Koninck).}

Corallum composite, forming hemispherical, depressed, or pyriform masses of prismatic or sub-eylindrical corallites. Walls of the corallites perforated by mural pores. Tabula well developed, resicular. Septa represented by vertical strie or ridges. Epitheea concentrically wrinkled, with root-like prolongations.

The corals of the genus. Mirlulinin approximate closely in their general characters to those belonging to Finsites. Michliniu is distinguished, however, by the vesicular nature of the tabulie, the generally larger size of the corallites, and the fact that the septa are present merely in the form of strix.

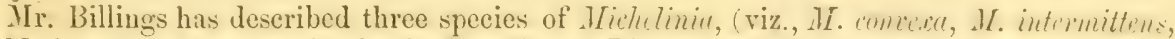
and M. furmolidea, as oceuring in the Corniferous Limestone of Western Ontario. Of these, snly the well known $\boldsymbol{M}$. convexa has come under my notice.

\section{Michelinia convexa (D’Orbigny).}

Mirhelinia convexa (D'Orbigny), Prodr.' de Paléont, t. I. p. 107.

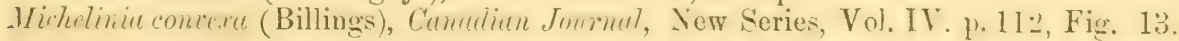

Corallum forming hemispherieal or pyriform masses of large :ize. Corallites polygonal, of unequal sizes, the larger ones from four to five lines in diameter, the smaller ones from or e 
to two lines in diameter, Septa represented by numerous (about forty) vertical striæ. Mural pores generally in two or three rows on each of the prismatic faces of the corallites, sometimes in one row, sometimes in several, distant from one another vertically from half a line to over one line. Tabule exceedingly convex and gibbous, usually with two, three, or four vesicular swellings round their margins, distant from one another from half a line to a line and a half.

Locality und Formution.- This fine species is of not uncommon occurrence at various localities in the Corniferous Limestone of Western Ontario. Amongst localities where it has been observed, may be mentioned Port Colborne ; Lot 6, Con. 1, Wainfleet; Oxford, near Woodstock, Ridgeway and Hagersville. It has also been recorded from the Devonian rocks of Michigan, and Preston County, Virginia.

\section{CHAPTER III.}

\section{Brachiopoda of the Corniferous and Hamilton Formations.}

The number of Bractiopedu in the Devonian Rocks of Western Ontario is very considerable, but good specimens are not obtainable in many parts of the Corniferous Limestone, and our collection of these fossils is not so complete as that of the corals. For this reason, I have, in treating of this group of fossils, availed myself largely of the published papers on this subject by Mr. Billings (C'anculimu Jom n., New Series. Vols. V. and vi.), and also of Prof. Hall's magnificent work on the Brechiopocle of the Devonian Formation of the State of New York (Pal. N. Y. Vol. IV). More especially our specimens, except in a fer instances, do not exhibit the internal characters of the valves, so important in this class of fossils, and these I hare generally quoted at length, for the benefit of Canadian students, from the works of one or ther of the above-mentioned eminent palæontologists.

Altogether, I have identified about forty-three species of Brachiopods from the Devonian of Ontario, belonging to the following genera:-Strophomena (seven species), Streptorhynchus (one species) Orthis (two species), Chonctes (seven species), Productella (one species), Spirifirl (five species), Cyrtinc (one species), Atrypa (two species), Athyris (two species), Leioihynchus (two species), Spririgerc (three species), Retwic (one species), Ampligenic (one species), C'alospira (one species), Centronellu (two species), Lingula (tro species), Plotidops (one slecies), and Crania (one species).

Of the above, a fow species (such as Strophomenu rhomboidalis, Spirifera mucronata, and Atrypa reticuluris) are well known European forms; and others are nearly allied to Eurcpeun species, if not quite identical with them ; but the greater number are peculiar to the American Continent.

\section{Strophonena perplana (Conrad).}

Strophomena perplana (Conrad), Journ. Acad. Nat. Science, Vol. viii. p. 257. Pl. XIV. fig. 11.

Strophomena pluristriata (Conrad,) op. cit., p. 259.

Strophomena detthyris (Conrad), op. cit., p. 258.

Strophonence crenistria (Hall), Report Fourth Geological District. New York, p. 17i, fig. 4 .

Strophomena fiagilis (Hall), Tenth Report on the State Cabinet, p. 143 ; and Rep. Geol. Survey of Iowa, p. 496. Pl. iii. fig. 6 a, $6 c$.

Strophomence porplenu (Billings), Journ. C'un. Institute, New Series, Vol. VI. p. 343.

Strophodonte perplinu; (Hall), Pal. N Y., Vol. iv. p. 98. Pls. XI. XII. XVIII. and XIX.

Form semi-elliptical or semi-circular ; the width exceeding the length, though not greatly. Valves flattened, or slightly concavo-convex, regularly rounded in front. Hinge-line straight, as long as, or longer than, the greatest width of the shell, which is sometimes extended towards the cardinal angles or almost auriculate. Ventral valve slightly convex, with it: greatest convexity at about one-third from the beak; the dorsal valve gently concave or 
nearly flat. Area of the ventral valve about one line wide at the beak, that of the dorsal valve being about half as wide. Both areas are striated, and they form with one another an angle of $90^{\circ}$ or a little more. There is no foramen, but sometimes a flat triangular space with a narrow median callosity.

Surface with numerous fine, equal or sub-equal strix, which increase in number in proceeding from the beaks to the margins, both by bifurcation and intercalation. Six to nine striæ occupy the space of a line; and these are crossed by close-set concentric strix, from ten to twelve in the space of a line. Besides the close cancellation thus produced, there are often irregular concentric undulations of both valves, and sometimes the bases of minute spines can be detected.

Average examples hare a width of about an inch by a length of about three quarters of an inch; but the width on the hinge-line varies from half an inch to two inches.

As regards the internal characters, Prof. Hall states (Pal. N. Y. Vol. iv. p. 100) that "the interior of the ventral valve is marked by large flabeliform divaricator muscular impressions, extencling more than half the length of the shell; narrow above, with sides nearly straight, curving below and deeply dividerl in front, each division showing four or fire lobes. The occlusor impressions are two semi-oval elevated spots a little below the apex, the centre becoming a thickened ridge or process lying beneath the place of the foramen, with a eavity on each side for the insertion of the bifurcate dorsal cardinal proces.. * * * The muscular impressions of the dorsal valve are distinctly but not strongly marked; these are separated above by a median ridge which divides in the bifurcating cardinal process, and this is supported on each side by an oblique pustulose ridge which griadually merges into the surface of the shell."

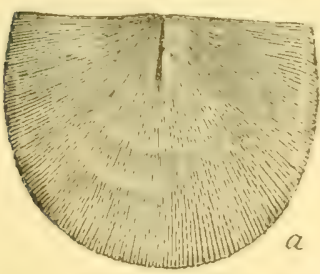

F10. 20.

Strophomena perplana (Conrad), belongs to a group of Strophomenoid shells separated by Prof. Hall from Strophomena proper, to form a new genus, which he terms Strophodonta. The chief peculiarity of the forms included by $\mathrm{Hall}$ in his genus Strophodonta is the absence of a foramen in the area of the ventral valve; but as the $\alpha^{\prime}$ forms in question are in most respects otherwise undistinguishable from the typical species of

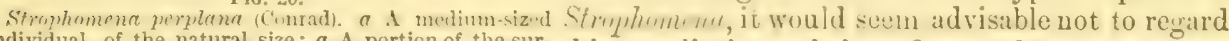
individual, of the natural size: $a$ A portion of the sur- this peculiarily as being of more than at any rate
face of the same, eniarser. Cirniferms Limestume. sub-generic ralue. St prplemu is an extremely characteristic species of the Deronian liocks of North America, and is in general rendily recugnised by its flattenel form, its fine equal striz, and the close concentric striation of the surface in well preserved specimens.

Loralitn and Firmatim. - Common in the Corniferous Limestone of Port Colborne, and lot 6, Con. 1, Wainfleet.

\section{Strophomena demissa (Conrad).}

Strmphumena demissa (Conrad), Journ. Acad. Nut. S'cimas, I'hilatelphica, Vol. VIII, p. 258, pl. 14, fig. 14.

Strophomena demissa (Hall), Tenth Report on the State Cabinet, p. 137. fig. 5 .

Strophuetrinte demisse (Hall), Report on the Geologivial Survey of Iowa, p. 495, Pl. III,

Struptemmene demissa (Billings), Journ. Can. Institute, New Series, Vol. VI, p. 341, figs. 116-118.

Strophodonta demissa (Hall), Pal. N. Y., Vol. IV, pp. S1, 101, 114.

Shell very variable both in form and in dimensions. The form is usually semi-elliptical, but may be sub-quadrate or sub-triangular. Usually the width of the shell exceeds the length, but sometimes both dimensions are equal, and occasionally the width is less than the length. The hinge line is usually equal to or greater than the greatest width of the shell, and the cardinal angles are often extended or auriculate. Specimens vary from a third of an inch to an inch and a half in width.

The ventral valve is convex, sometimes strongly so, and the convexity is usually uniform and regular from the umbo to the ventral margin. The dorsal valve is moderately concave. 
The beak of the ventral valve is small, prominent, and slightly incurved; the area of m:derate width, and sometimes with a smooth triangular space occupying the place of the firamen. The dorsal area narrow.

The surface is marked with "numerous crowded striæ, about nine or ten of which are in uch stronger and more elevated on the umbo of the ventral valve, with finer ones coming in between and on either side; stria frequently increasing by intercalation and bifurcation, until they become very numerous and much finer at the margin. On the dorsal valve, the strix are similar to those of the ventral valve" (Hall).

According to the observer just quoted, "the interior of the ventral valve, and casts of the same, show a large flabelliform divaricator muscular impression, which is somewhat widely separated in front, and each division distinctly lobed. The occlusor muscular impressions occupy a semi-elliptical space on each side of a narrow central depression, the marking on cither side being double in well preserved specimens. The upper extremities of this impression are close under the arch of the umbo, and separated by a smooth space from the divaricator impressions. Beyond the muscular impressions, the interior surface is minutely pustulose, the points being more prominent just without their limits; beyond which the course of the vascular impressions can be distinctly traced. In the dorsal valve the anterior and poisterior occlusor muscular impressions are very conspicuous and deeply marked, and often limited by an elevated ridge, a narrow longitudinal ridge dividing the two pairs. On each side, and below the muscular impressions, the surface is marked by small pustules or tubercles; and beyond these the surface is minutely pustulose, the vascular impressions becoming distinct towards the margin. The cardinal prccess is divided from the base, the divisions strongly diverging." (Puloeontologg of New York, Vol. IV, p. 103.

$S$. demissc, like the preceding, belongs to the section elevated by Hall to the rank of ngenus under the name of strumluchonte. It is a variable species, and unless the hinge-line be preserved with the area, it is not alw ys possible to refer examples to it with certainty. The species necurs in almost every sub-division of the Devonian series of North America.

Luculity and Formation.-Corniferous Limestone of Port Colborne and of numerous other localities in Western Ontario.

\section{Strophomena inequistriata (Conrad).}

Strophomena inequistriatn (Courad), Journal Acad. Nat. Sciences, Philadelpluia, Vol. VIII., p. 254, Plate XIV. Fig. 2.

Strophrmence incquistriata (Hall), Geol. Rep. 4th District, p. 200, Fig. 4; and Tenth Report on the State Cabinet, p. 142.

Strophomena inequistriatu (Billings), Journal Canadian Institute, New Series, Vol. VI., p. 338 .

Strophodonta inequistriato (Hall), Pal. New York, Vol. IV., p. 106, Plate XVIII, Figs. $2 a-k$.

[Compare Orthis interstrialis (Phillips), Pal. Foss. p. 61, Plate XXV. Figs. 103 (t-d; Leptemu interstriulis (Davidson), Brit. Fossil Brachiopoda, p. 85, Plate XVIII., Figs. 15-18; Strophedenta varistriata, var, areta ( $\mathrm{H}_{\text {alll }}$ ), i'al. New York, Vol. III., p. 183, Plite 18, Figss. I $a-i$; Stophodonte textilis (Hall), Pal. New York, Vol. IV., p. 108, Plate XVIII. Fig. 3; and Strophodonta concava (Hail), Pal. New York, Vol. IV., p. 96, Plate XVI.]

Shell semi-oval or semi circular, widest at the hinge-line, which varies from one to three inches in length. Cardinal angles usuilly somewhat acute, and sometimes eared. Width of the shell usually from a fourth to a third greater than the len th. Valves concavo-couvex; the ventral valve convex, with a variable curvature, often abruptly arched towards the margin; the dorsal valve concave, but generitly less sirongly curved than the ventral. Beak of the ventral valve apparently very variable in its prominence; the area narrow, vertically striated, and crenulated in the neighbourhood of the beak.

surfice marked with distant elevated simple strix, which increase towards the margins of the shell by interstitial additions, and which are separated by flat or slightly coucave interspaces, distant from half a line to a line at the marcin. These interspaces are oceujied by exceedingly fine and close longitudinal stria, from four to eight existing in one interspace. Further, the coarse and fine ridiating stria are cancellated by a crowded series of excedingly fine and el se-set concentric strix. 
As regards the internal characters of this species, according to Professor Hall, "in the interior of the ventral valve, the occlusor muscular impressions vecupy a narrow, subquadrangular elevated space, just beneath the apex, whilst the divaricator muscular imprints occupy a short broad space on each side, and are limited by nearly vertical or slightly curving ridges which have in some degree the appearance of dental lamella ; within the limits of these ridges the muscular imprints are not strongly marked. In the dorsal valve the posterior occlusor imprints are broad and extending far towards the cardinal line, and often limited externally by a low pustulose ridge; the anterior impressions are small and narrow, separated by a narrow mesial ridge, and margined by diverging elevated ridges, which, above the impression, are united in the mesial ridge from which proceeds the bifurcatincr cardinal process."

S. inequistriuta is placed by IIall in his genus Strophotimetu, and is stated to possess no foramen; but Mr. Billings asserts that a small linear foramen is present. In most respects S. inequistriuta appears to be identical, as pointed out by Hall, with Lepterna (Orthis) inteistrinlis, (Phillips), from the Middle Devonian of England and Europe; and no other distinctons can be at present laid down between the two forms, except that the latter is upon the whole somewhat smaller, and that it does not seem to possess the fine concentric stria of the former. When the internal characters of $L$. iuterstriulis are known, other differences may perhaps appear. It may also be doubted, as pointed out by Mr. Billings, if S'. incyristrutu is specifically distinct from the Devonian forms described by Hall under the names of ts.tertilis and $s$. comcarce. Lastly, S. inequistriutu is closely allied to the s'. vuristriutu of the Lower Helderberg

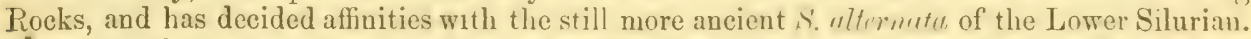
I'am unable to see that there are any differences of speeific value between this and inequirediute Hall, though the opposite is maintained by Hall. S. incynistricten may in general be readily recognized by the characters of its surfice-ornamentation and by its shape.

Loculity and Formation. - Corniferous limestone, Port Colborme; Lot 6, Con. 1, Wainfleet ; Ridgeway, and generally throughout the Corniferous and Hamilton formations of Western Ontario.

\section{Strophomena Patersoni (Hall).}

Strophomenu Patrseni (Hall), Tenth Report on the State Cabinet, p. 114.

Strophomena I'utersuni (Billings), Jour. C'un. Institute, New Series, Vol. VI., p. 340, Fig. 115 .

Shell semi-oval, ventral valve convex, depressed towards the cardinal angles, which are slightly extended or aurieulate. "Surface marked by distant elevated radiating striee, and the intermediate spaces by undulatiug fine striat, and crossed by short alnuptly arching wrinkles, which are interrupted by the strong radiating stria. The finer radiating stria on the ventral valve are from three to ten or twelve between the stronger ones; whilst on the dorial valve the spaces are wider, and there are from ten to twenty finer stria between the stronger ones. The finer strie are crossed by equally fine concentric strix, giving the entire surface a delicately cancellated appearance," (Hail, Pal. N. Y., Vol. IV., p. 89).

S. P'atersoni is very closely allied to $s$. inequistriata, from which it is perhaps not specifically distinct. The chief points of distinction are to be found in the sualler convexity of the ventral valve in S. Putrsomi, in the greater number of the fine intermediate strie, and in the presence of weil-marked concentric wrinkles. S. I'atersuni is also allied to the Silurian S. corrugata of Portlock, but the latter is a flatter and smaller form.

Locality and Formation.--Not uncommon in the Corniferous Limestone of Ridgeway, and Lot 6, Con. 1, Wainfleet.

\section{Stropiomena ampla (Hall).}

Strophomena ampla (Hall), Tenth Report on the State Cabinet, p. 111.

Strophomena ampla (Billings), Jour. C'un. Institute, New Series, Vol. VI., p. 345.

Strophodonta ampla (Hall), Pal. N. Y., Vol. IV., p. 93, Pl. XIV., $1 a-1 i$.

Shell large, from two to three inches wide, the length from a fourth to a third less, semi-oval or semi-circular, the hinge-line as wide or wider than the greatest width of the shell below. Ventral valve concave, with a slight convexity near the beak; dorsal ralve convex, with a concavity in the neighbourhood of the beak, following the curvature of the ventral 
valve. Area of the ventral valve from one to three lines in width, transversely striated for from one-third to one half of the distance from the beak to the cardinal angles. Dursal area narrow and linear.

"Surfuce marked by angular, sub-equal, interrupted or rugose striæ, which are often made to appear more uniform by the partial exfoliation of the shell. The striæ are bifurcated two or three times before reachiug the margin, and they are sometimes increased by intercalation. As usually preserved, they rise at intervals into sharp ridges or elongated nodes; and in well-preserved specimens these are produced into short spines. When the shell is exfoliated, the surface betrveen the stria is marked by minute pores or tubular openings, which communicate with pustulose elevations on the interior surface of the shell. In the entire cast, these pores mark the surface with considerable regularity, varying in size, and uniformly larger below the middle, where the valve is more abruptly reflected.

"The muscular impressions of the ventral valve are very large and broad, and the mar. gins distinctly limited by a curving elevated border. It is divided in the middle by a more or less developed septum, which terminates in a prominent callosity beneath the place of the foramen: this callo-ity gives a bilobate character to the cast of the rostral cavity. The place of the occlusor muscles is strongly marised, and that of the divaricator muscles distinctly bilobed. The muscular imprints are about two-thirds as long as wide, and the width is often nearly equal to half the width of the shel!. The muscular impressions of the dorsal valve are narrow and elongate, and are separated by a rounded median ridge, which divides above and continues in two diverging processes, the full extent of which is not shown in any of our specimens," (Hall, Pal. N. Y., Vol. IV., p.94).

Professor Hall places S. ampla in his genus Strophoctonta, and states that the place of a fora. men is taken by a smooth triangular space with a narrow callosity along its certre. According to Mr. Billings, however, there is a small linear closed foramen, one-third of an line in width. It seems very doubtfiul if there is any difference of specific value between $S$. ampla and the more ancient Lower Helderberg species. S. punctulifere Courad), S. Heudleyana (Hall), and S. cuvunbonce (Hall . Mr. Billings points out that S. cemple and S. punctulifere are substantially identical, the Corniferous specimens, however, being on an average larger than those figured by Hall from the Lower Heldelberg. I have, however, collected examples of S. punctulifern the dimensions of which are fully equal to those of the Devonian form. It would probably be wise, therefore, to substitute s. punctulifere for s.. umplu, retaining the names Healleynat and ravumlion in the meanwhile as designations of varietal or sub-specific value, thus carrying out Professor Hall's own view that a more extensive series if specimens will show that all these forms belong to " one species presentiug variations of size, degree of convexity, width of area, and difference of surface-markings due to the influence of the sediment and other surrounding condlitions which affect the development of animal life." (For descriptions and figures of S. Headleymu. S. comumbonu, and S. punctuliter, sce Palæontol gy of New York, Vol. III, p. 185, Pl XX., Figs. 1-3 ; p. 187, Pl. XXI, Figs. 1-3, and p. 18s, Plate XXI, Fig. 4, and Pl. XXIII, Figs. 4-7.

Stroplumme cimplu may as a rule be recognized by its peculiar form and the characterise tic ornamentition of the surface. The commonest appoarance is when the shell is partially exfoliated and the punctia between the strix are visible. Spines cannot usually be detected, but Mr. Biilings has figured a specimen in which the whole surface is adorned with short. spines.

\section{Locality and Formation.-Corniferous Limestone of Port Colborne.}

\section{Strophomena nacrea (Hall).}

Strophomena (Strophodonta) nacrea (Hall), Tenth Report on the State Cabinet, p. 14 . Strophodonta lepida (Hall), Gcol. Report, Iouca, Vol. I., Part ii., p. 493, Pl. III., figs. 3, $a, b, c$.

Strophomena lepida (Billings), Journ. Cun. Institute, New Series, Vol. VI. p. 344.

Strophodonta nacrea (Hall), Pal. N. Y., Vol. IV., p. 104, Pl. XVIII., figs. 1, $a, b$.

Shell small, from four to nine lines wide, and from three to six lines long, semi-circular, or sub-quadrate, the hinge-line crenulated and as wide as, or wider than, the shell below. Front margin rounded, cardinal angles rounded or extended and angular. Ventral valvo 
regularly but not greatly conrex, depressed towards the cardinal angles. Area narrow, linear, without foramen; beak small. Dorsal valve concave. of growth.

Surface shining, smooth, without radiating strix, but with very faint concentric lines

"The muscular impressions in the ventral valve extend more than half the length of the shell. The divaricator muscular imprints are deeply depressed, elongate-ovate, narrowing ubove, and somewhat widely separated below; while the occlusor impressions are narrow ovate spots on the thickened portion of the shell, and below these extends a narrow elevated band separating the other impressions. In the dorsal valve, the anterior and posterior occlusor impressions are small and not strongly defined. The cardinal process is slender, bifurcating, with a narrow rounded ridge extending from its base down the middle of the valve. The interior of the shell, excepting the muscular impressions, is studded with prominent scattered granules or papillæ. The crenulations on the hinge-line are rather distant but couspicuous." (Hall, Pal. N. Y., Vol. IV., p. 104).

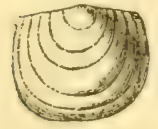

Fig. 21.

Strophomena wacrea, ( $\mathrm{Hall})$, of the natural size. Corniferous Lime. stone.

\section{Locality und formation.-Rare in the Corniferous Limestone of Port Colborne.}

\section{Strophomena rhombondalis (Wahlenberg).}

This well-known species is so fimilizr to all students of Palanzoic frenlogry, and its characters are so readily reconised, that it scems unnecessary to occupy space here with a description of its peculiarities, or a recapitulation of its ponderous synonymy. It may, as a rule, be determined at once by its rhomboidal form, the deep concentric wrinkling of the risceral dise, and the abu upt geniculation of both valwes towatrds the dorsal side at a point situated at from one half to two thirds of the length measured from the beak. S. rhombinitalis is known to have commeneed its existence as carly as the Lower silurian period; it is : $n$ abundant Upper Silurian fossil ; it is found throughout the Devonian; and it even extends into the Carboniferous rocks.

Lorality and formatim.-C'ommon throughout the Corniferous J.imestone of Western Ontario. Also in the IIamilton group of the same district, though not known in the Hamilton series of the State of New York.

\section{Genus Streptorhynchrs (King).}

The genus Streptorhynchus: includes strophomenoid shells of a semi-circular or semielliptical shape, "concavo-convex or plano-convex, and sometimes with both valves convex; they are externally striated with rounded bifurcating thread-like strix, which are crossed by fine concentric lines; and in some forms the strnnger strix are distant, with finer radiating and concentric stria cancellating the intermediate spaces. The ventral beak is sometimes produced and bent or twisted, and the fissure beneath the beak is closed or partially closed by a solid deltidium, while the area is subject to great variation. A narrow area often exists on the dorsal valve, but this is not a constant character." (Hall, Pul. N.Y., vol. iv, p. 64).

The genus Streptorhynchus is very closely allied to Strophomene proper, the most obvious external character by which the former is distinguished being the irregular twisting of the beak of the ventral valve. The genus is represented in all the great palaozoic formations, from the Lower Silurian upwards, and appears to be very abundantly represented in the Devonian Rocks of North America, so far as individuals are concerned, Prof. Hall, however, refers all the Devonian forms of this genus to one exceedingly variable species, the Streptorhynchus Chemungensis of Conrad. Only one form of the group has been recorded as yet from the Devonian Rocks of Uanada, namely, the S. Pandora of Mr. Billings. 


\section{Streptorhynchus Pandora (Billings).} $12,13$.

Streptorluynchus Pandora (Billings), Canadian Journal, New Series, vol. v. p. 266, figs.

Streptorhynchus Chemungensis, var. Pandora (Hall), Pal. N.Y., vol. iv, Pl. IV, figs. 11, 19 ; and $\mathrm{Pl}$. IX, figs. 18,25 , and 27.

1 and 2$]$.

[Compare Strophomene Woolworthana (Hall), Pal. N. Y., vol. iii, Pl. XVI, figs.

Shell semi-oval, about one-fourth wider than long; the hinge-line equal to the greatest width of the shell, and forming right angles with the nearly straight sides, whilst the front margin is broadly rounded. Ventral valve elevated at the umbo, whence the surface slopes in all directions to the margin. Area of the ventral valve large and triangular, extending the whole length of the hinge-line. Foramen large, triangular, about twice as wide at the base as the height, nearly or quite closed by a convex deltidium. Dorsal valve moderately conrex, slightly depressed towards the cardinal angles, with a narrow area.

Surface marked by fiue strongly elevated thread-like strix, which are sometimes alternately large and small, and which inerease in approaching the margin both by bifurcation ano interstitial addition. About four strix in the width of one line, sometimes more.

"The interior of the ventral valve is marked by strong dental lamellæ and a broad flabellate muscular impression, which in well preserved specimens shows the cordiform imprint of the adductors, and a short low mesial septum in the upper part. The interior of the clorsal valve preserves deep dental sockets, with thick socket plates which support the duplicate cardinil process, cach division of which is grooved at the extremity. There is likewise a smgll process between the two branches of the cardinal process; and below the hingeline, the flabelliform muscular impression is divided by a low rounded mesial longitudinal ridge or obsolete septum." (Hall, Pal. N. Y., vol. iv, p. 68.)

Average specimens have a width of about an inch and a quarter by an inch in length. but larger individuals are known to occur.

According to Hall, Streptorhynclus Pandora is merely a form of the vary variable $S$. Chemungensis, (Conrad). There is, however, some doubi as to whether the specimens examined by Hall really belong to S. Pondora, (Billings); since he states that the longitudinal strix are "crenulated by fine closely arranged concentric strix." This is certainly not the case with any of the specimens which hare come under my notice, and Mr. Billings explicitly notes the absence of concentric stria in the examples upon which he founded the species. Hall, also, states that a small central process exists between the two divisions of the cardinal process, but Mr. Billings states that no such process exists in S. Pundora. It thus remains uncertain whether the New York specimens are identical with these from Ontario. S. Pandora is nearly related to the well known European species S. crenistria, from which its only import. ant external difference is the absence of crenulating strix.

Locality and Formation.-Corniferous Limestone, of Port Colborne, and Hagersville.

\section{Genus Orthis (Dalman).}

"Shell variable in shape, sub-cireular or quadrate; valves equally or unequally convex; socket valve sometimes slightly concave, with or without a mesial fold or sinus; hinge line straight, generally shorter than the width of the shell; both valves furnished with an area divided by a triangular open fissure for the passage of the pedicle fibres; beaks more or less incurved, that of the larger valve generally more produced; surfice, smooth, striated, or ornamented by simple, bifurcated, or intercalated ribs; structure minutely or largely punctated; valves articulating by means of teeth and sockets. In the interior of the larger or ventral valve the vertical dental plates form the walls of the fissure, and extends from the beak to the bottom of the shell; between these a small rounded mesial ridge divides the muscular scars, which extend over two elongated depressions margined on their outer side by the prolonged bases of the dental plates; the cardinal muscles appear to have occupied the greater portion of the anterior division of these two depressions, the pedicle muscles occupying the external and posterior part of the same space; the adductor was probably attached to each side and close to the mesial ridge. In the socket valve the fissure is partially or entirely occupied by a more or less produced simple shelly process, to which were affixed the cardinal 
muscular fibres; the inner socket walls are considerably prolonged into the cavity of the shell, under the shape of projecting lamina, to the extremity of which free fleshy spiral arms may, perhaps, have been affixed. Under this shelly process a longitudinal ridge separates the quadruple impressions of the adductor, which on each side forms two deep oval depressions, placed obliquely one above the other, and separated by lateral ridges branching from the centre one." (Davidson, Brit. Foss. Brachiopoda, Introduction, p. 102).

The genus Orthis is very nearly related to Strophomenu, from which the more typical forms may in general be easily separated by their usually greater convexity, and the rounder and shorter hinge-line. Two species of the genus, viz. : $U$. Licin and $O$. I tum trimi have been recorded by Mr. Billings as nccurring in the Devonian Rocks of Ontario, and both of these have come under my observation.

\section{Orthis Lrvia (Billings).}

Orthis Livia (Billings), Canadian Jnurnal, New Series, Vol. V. p. 267, Figs. 14-16. Orthis Livia (?) (Hall, Pal. New York, Vol. IV., Figs. 4a-4c.

"Sub-orbiculitr or sub-yquadrate : length ahout eight ninths of the wilth; greatent width, usually a little in front of the middle: leneth of hinge line, one-half to two-thirds the width of the shell ; cardinal extremities rounderl; sides in mo-t specimens somewhat straight, often sufficiently curved to give a circular aspect to the shell; front angles obtusely rounded ; front marcin in ceneral broadly conves, sometimes with a small space in the middle nearly straisht. Dorsal valve of a medium convexity, most elevated about the middle ; the outline forming a unifirm arch from the depressed beak to the front margin; the slnpe from the umbotowards the carlinal angles, grertly concive; sometimes a barely perceptible mesial depression, commencing in a point at the beak, and becoming obsolete at one-half or two-thirds the length; area small, lying in the plane of the lateral matrins; buak minute, forming a small trian-ulan projection, rising scarcely one-fourth of a line above the edge of the area. the point not incurved over, but situated in the plane of the area. Ventral valve moderately conver, most eleritin? at between one-fourth and one third the length from the beak, thence de-cending with a sum. what flat or gently convex slope, to the front and sides, and with a more sudden and som, shat eoncave siope to the hinge line and cardinal ancles: the umbo small, prominent, natly defined, terminating in a small rounded beak, which is incurved so as to overhang the c i-e of the area, either not at all or scarcely one tenth of a line ; area triangular, about one fir in larger than that of the dorsal valve, forming an angle of about 10.; with the plane oi the lateral marein. The formen not observed, but aupears to be wider than high. ()n knkinz at the dorsil valve in a direction perpendicular to the plone of the shell, the small rou dited umbo of the ventral valve ean be seen rising about one-third of a line above the dorsal b, ...

"Surface with small sub-angular radiating rilges of nearly a uniform -ize, from cight to ten in the width of three lines, increasing by hifurcation, strongly curved outwird in the upper part of the sides and cardinal angles, the intervening srooves sub-angular in the bitnm. and equal to the ridges in width. In very perfect specimens, very fine concentric -nb-lidmellar concentric stria are visible, seven or eight to one line. In certain couditions of meservation also, the radiating ridges are seen to be sub-tubular, and exhibit numerous small ovia! or circular openings on their edges, each about the eishth or tenth of a line in width, aud? from one-fourth to two-thirds of a line distant from each other.

"Width of largest specimen examined, eighteen lines; length. sixteen lines; thickuesor depth of both valres, seven lines; height of area of ventral valve at the beak, one line; areat $f^{2}$ dorsil valve four-fifths of a line; distance between the beaks, one line; length of hinge-line. ten lines. The most commun size appears to be one inch in width. The beak of the ventral valve is incurved, so that it would touch a plane projected horizontally through the valve, at one-hillf* the depth of the cavity.

"In some specimens the ventral valve has a faint, barely perceptible mesial fold, extending from the umbo towards the front." (Billings).

I have very little to add to the above exhaustive description of O. Lixin, by Mr. Billings, the only two additional points of importance that I have observed being the follow. ing:-1. The foramen is very large, and is more than twice as wide at the base as it is hi $i_{2}$. 2. The margin of the shell exnibits, in adult specimens, seseral well-marked concentric rid rus. of growth, which are quite independent of the fine concentric striæ which some exumples piescut. 
Orthis Livia is an exceedingly elegant species, and can usually be recognised without any difficulty. It is allied to 0 . Vunuxemi, (Hall), but is a larger form, and is more coarsely ribbed.

Lncality and Formation.-Corniferous Limestone of Port Colborne, and Lot 6, Con. 1, Wainfleet.

\section{Orthis Vanuxemi (Hall).}

Orthis Vanuxemi (Hall), Tenth Report on the State Cabinet, p. 136. $18,19$.

Orthis Vanuxerni (Billings), Canudian Journul, New Series, Vol. V., p. 269, figs. 17,

\section{Orthis Vanuxemi (Hall), Pal, N.Y., Vol. IV. Plate VI., fig. 3.}

Shell very nearly circular, compressed and flattened; hinge-line very short, rounded. Dorsal valve gently and regularly convex; the beak hardly prominent, not incurved; the area narrow and linear. Ventral valve with its greatest convexity in the neighbourhood of the beak, nearly flat, or commonly slightly concave towards the front; the beak small, but more prominent than that of the dorsal valve, somewhat arched. Area narrow and curved, about one-third wider than the area of the dorsal valve. Foramen comparatively large, wider than high, triangular. Surface covered with close-set, fine, elevated strix, which increase both by bifurcation and interstitial addition, and which are indistinctly cancellated by concentric strix. About five strix in the space of a line, but more in the neighbourhood of the beaks. Entire surface minutely punctate; a few concentric, imbricating lines of growth.

As regards the characters of the interior, "the dorsal valve shows a strong cardinal process, which is continued in a prominent rounded median ridge for half the length of the shell, where it sometimes divides, or gradually becomes obsolete; there are sumetimes visible low transverse ridges, which divide the muscular impression. 'I he crural processes are prominent, and sustained below by strong oblique ridges. In the interior of young specimens, the marks of the extern:il stria are visible nearly or quite to the muscular impression; while in older speciinens these marks extend little beyond the margin. The interior of the ventral valve is marked by a large flabelliform nuscular impression, which reaches from one-half to two thirds the length of the shell. The central or adductor impression is sometimes simple, and sometimes longitudinally divided by a slight median ridge, which is stronger below. In the older shells the ovarian spaces are pustulo-e. The dental lamellæ are strong and divergent, supported below by the ridge which margins the muscular impression. Vascular impressions are rarely seen extending beyond the muscular area. Under a lens, the interior surface is distinctly punctate. In all well-preserved specimens the exterior shows minute tubular openings in the strix; and when the stria are much worn, these also are to be seen to be tubular, while a farther wearing of the surface shows more distinctly the minute punctate character of the shell."-(Hall, Pal. N.Y., vol. iv., p. 47.)

Orthis Vanmini is one of the most characteristic of the Brachiopods of the Hamilton Formation, and though not particularly abundant in Western Ontario, it is a very common species in the State of New York. It is distinguished from $O$. Livia by its finer striation and its more circular form. It is also a smaller species, average specimens having a width of about thirteen lines, and a length of about eleven lines and a half, though examples both smaller and larger than this are not uncommon. Small specimens are not at all unlike the Orthis hybride (Sowerby), of the Silurian Rocks of Europe and North America. There is, also, considerable doubt as to whether the $O$. leucosia and 0 . Penelope of Hall, from the Hamilton group of the State of New York, can be regarded as more than mere varieties of 0 . Vamuxi.

Locality and formation.-Hamilton group of Widder and Bartlett's Mills, near Arkona, in the Township of Bosanquet. Al $\mathrm{ko}$ at Canandaigua and at various other localities in the Hamilton Formation of the State of New York.

\section{Genus (Honetes (Fischer).}

Shell semi-oval or transversely oblong, with a wide straight hinge-line. External margin of the area of the ventral valve furnished with a row of tubular spines. Surface radiately striated, often spinose. Foramen in the ventral area distinct, but partially closed by a pseudodeltidium. Valves articulated by teeth. Dorsal valve with a cardinal process which is simple at the base, but bifid or grooved at the extremity. Interior of the shell pustulose or papillose. 
The genus Chonetes is nearly allied to Producta, from which it is distinguished by its articulated valves and row of tubular spines on the margin of the ventral area, as well as by other characters of less importance. The spines, unfortunately, are preserved only in the smaller number of specimens, and thus the affinities of a given example have often to be decided apart from this character. Even in the absence of this, however, Chonetes may generally be distinguished with ease from Producte by the fact that the ventral valve is proportionately less gibbous and ventricose, and the surface striation is finer. On the other hand, the genus Chonetes in form and external appearance makes an approach to the genera Strophomena and Leptona, and it may thus be regarded as being to some extent a link between the families of the Strophomenidee and Productidce.

Six or seven species of Chonetes occur in the Corniferous and Hamilton formations of Canada, of which one, viz., C. hemispherica has previously been recorded by Mr. Billings ${ }^{6}$ and all are found in the same formations in the State of New York.

\section{Chonetes lineata (Vanuxem).}

Strophomena lineata (Vanuxem), Geol. Report of the 3rd District, New York, p. 139, Fig. 6. Chonetes glabra (Hall), Tenth Report on the State Cabinet, p. 117.

Chonetes lineata (Hall), Pal. N. Y. Vol. IV. p. 121, Pl. XX. Fig. 3.

Shell semi-oval, the length about four-fifths of the width; hinge-line equal to the greatest width of the shell, and forming about right angles with the sides of the shell. Ventral valve very convex, or ventricose, regularly curved from the umbo to the front, the cardinal angles slightly flattened. The sides of the ventral valve nearly straight and the front margin broadly rounded. The dorsal valve concave, the concavity being less than the convexity of the ventral valve. Area of both valves very narrow, that of the dorsal valve linear. Cardinal spines rarely preserved, small, slightly oblique to the hinge-line, rarely more than two or three visible on each side of the hinge line. Surfice marked with numerous slightly elevated rounded stria, about ten in the space of one line, which increase in number by bifureation and interculation in proceeding from the beak to the margin. In well preserved specimens extremely fine concentric strixe can also be observed. The interior of the dorsal valve exhibits lines of pustules, corresponding with the strix outside.
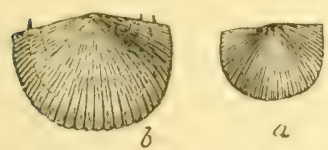

(l)

Fig. 22.

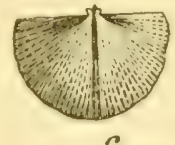

c

Chonetes lineata is of not uncommon occurrence in the Devonian Rocks of Canada, both in the Corniferous Limestone and the Hamilton formation, but especially in the latter. Average examples have a width of five lines and a length of about four lines. It is readily distinguished by its general form and surfice characters, and it seems very probable that

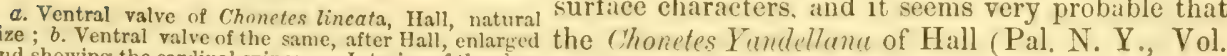
and showing the cardinal spines, c. Interior of the dor- iv., Pl. $\mathrm{xx}, \mathrm{Fig}$. 4.) is nothing more than a variety
ial valve of the same. All from the Hamilton group. of this species.

Locality and formation.-Corniferous Limestone of Hagersville and Port Colborne. Abundant in the Hamilton Formation of Bartlett's Mill, near Arkona, in the Township of Bosanquet.

\section{Chonetes scitola (Hall).}

Chonetes scitula (Hall), Tenth Report on the State Cabinet, p. 147.

Chonetes scitula (Hall), Pal. N.Y., Vol. iv., Pl. XXI., Fig. 4.

Shell small, semi-oval or semi-circular, the width exceeding the length by from one fourth to nearly a third (usually about five lines in width, by three and a half in length). Hingeline usually not quite equal to the greatest width of the shell, generally producing rectangular cardinal angles. Sides nearly straight; anterior margin rounded broadly. Ventral valve convex, depressed towards the cardinal ancles, sometimes regularly curved from the beak to the front, sometimes with a slight mesial depression almost approaching a regular sinus. Dorsal valve very concave, closely applied to the convexity of the ventral valve. Area of the ventral valve, narrow, broadest in the middle. its plane coinciding with that of the cardinal angles. Foramen partially closed by a convex deltidium, partially filled with the cardinal process of the dorsal valve; its shape broadly triangular. Dorsal area linear, about half the width 
of the ventral. The cardinal margin of the ventral valve generally shews very distinctly the bases of five tubular spines on each side of the umbo. The surfice is marked by fine, subequal, usually rounded, radiating strim, those near the margin often alternating in size. There are about six of the larger strix in the space of one line, and there are between fifty and sixty strix at the margin of the shell, the increase in proceeding from the beak being effected partly by bifurcation and partly by intercalation. In well preserved specimens fine concentric striae are also visible.

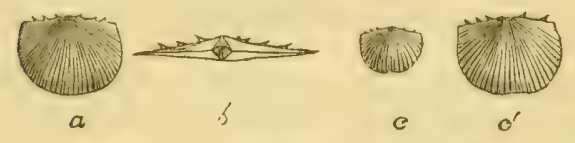

Fig, 23.

This pretty little species occurs quite commonly in the decomposed shales of the Hamilton group at Widder, generally in a state of beautiful preservation. It is nearly alied to Chonetes lineata, the most satisfactory distinction seeming to be that the dorsal valve is much more deeply a. Chonetes scitula, Hall, natural size. b. Area of the concave than in the latter species, whilst the

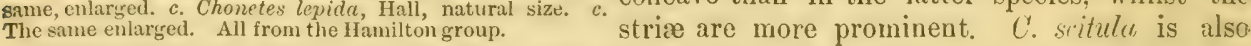
very nearly related to C. lepide ( $\mathrm{Hall}$ ), and I should doubt if the latter is truly more thau the Joung of the former. The chief character relied upon to separate these species is that $C$. scitulu has the ventral valve uniformly convex, whilst there is a mesial depression in that of $C$. lepicla. I have, however, specimens in other respects entirely arreeing with C'. scitul a slight mesial sinus of the ventral valve. Nevertheless, in deference to the authority of the great American palieontologist, I shall in the meanwhile retain $C$. lepida as a distinct species.

Locrlity anel formation.--Common in the Hamilton Formation of Widder, in the Township of Bosanquet.

\section{Chonetes lepida (Hall).}

Chonetes lepida (Hall), Tenth Report on the State Cabinet, p. 148.

Chonetes lepida (Hall), Pal. N. Y., Vol. IV., p. 132, Pl. XXI., fig. 5.

The shell in this species in all essential respects agrees with that of $C$. scitula (Hall), and the following may be noted as the only points of distinction :-

1. The form of the shell is sometimes nearly hemispherical, and the width of the hingeline equals that of the shell below.

2. The gibbous ventral valve exhibits a longitudinal mesial depression, bounded on eack side by stria rather larger and more prominent than the rest.

3. The hinge-line usually exhibits the bases of two or three spines on each side of the beak, but as many as five on each side can sometimes be detected.

4. The number of the radiating strix on the margin is only about twenty four or twentyfive; but smaller stria are sometimes intercalated between these, raising the total number to about fifty.

As before stated, my own impression is, that Chonetes lepirle is the young of C. scitulu. Upon this subject, however, Prof. Hall has the following remarks :-

"The original specimens designated as C. lepulu are very small shells of almost hemispheric form, and one of the characteristics is the mesial depression of the ventral valve. 'The stria are rather strong, angular, and, from dividing below, have the appearance of being fasciculate. More extensive collections have brought together a largenumber of individuals; and while the characteristic features are preserved in most of the specimens, there are others of the same size which seem like the young of $C^{2}$. silulu, but the well-marked specimens of this species have a convexity which precludes them from acquiring by growth the form and convexity of C. scitula in its characteristic phases," (Pal. N. Y. Vol. IV., p. 133).

Locality and formation. - Small specimens having the characters ascribed to C. Iepride are not uncommon in the decomposed shales of the Hamilton group, at Widder, Township of Bosanquet.

\section{Chonetes mucronata (Hall).}

Strophomena mucronata (Hall), Geol. Report, 4th District, New York, p. 180, fig. 3.

Chonetes laticosta (Hall), Tenth Report on the State Cabinet, p. 119.

Chonetes mucronata (Hall), Pal. N. Y., Vol. IV., Pl. XX., fig. 1, and Pl. XXI., fig. 1.

Shell small, semi-oval, or more or less auriculate, the hinge-line equal to or greater than the greatest width of the shell below. Ventral valve strongly convex, depressed towards the 
cardinal angles; dorsal valve very moderately concave or nearly flat. The surface is markea by firom twenty to twenty four simple, sub-angular ribs, some of which are occasionally bifur. cated towards the margin, and which are separated by interspaces wider than themselves. In the eared examples the ribs are obsolete towards the cardinal angles. "The cardinal margin shows two and rarely three spines on each side of the cotre, which are abruptly bent outwards so as to lie nearly parallel to the hinge-line, and the outer one extending much beyond the cardinal extremity. The area is very narrow," (Hall).

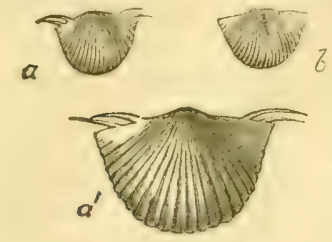

Fig. 21.

a. Chonetes moronata, natural size, after Ifall; a. The same eltlargeal; $b$. i specimen of $C$. mucrcnata from the Corniferous Limestone of Ontario. Niatural size.

Some of the points mentioned in the above description $I$ have not been able to verify from our specimens, as they are mostly imperfect. Thus, I have never seen either a dorsal valve, or a ventral valve exhibiting the spines. Upon the whole, however, I have no doubt but that our specimens are truly referable to $C$. mucronata, as they agree with Hall's description of this species in all essential characters, so far as observed. As occurring in the Marcellus Shale, the ventral valve is stated by $\mathrm{Hall}$ as being only slightly convex or nearly flat; but as occurring in the Corniferous Limestone and Hamilton group, it is said to be "often quite gibbous." Our examples agree with the latter in this, and only differ in having the cardinal angles more or less produced and salient-a phe. nomenon, however, which Hall states to be of occasional oocurrence. 'The species is nearly allied to Chonetes deflecta (Hall), and the two are, perhaps, only varieties of a single species.

Locality and formation.- Rather abundant in the Cornifernus Limestone of Rama's Furm, near Port Colborne.

\section{Chonetes hemispherica (Hali).}

Chonetes hemispherica (Hall), Tenth Report on the State Cabinet, p. 1 I6.

Chonetes hemispherira (Billings), Cuncelimn Jourmul, New Series, Vol. VI. p. 3.19, Figs. 121-123.

Chonetes hemispherica (Hall), Pal. N. Y. Vol. IV. Pl. XX. Fig. 6.

Shell semi-oval or semi-circular, the greatest width being along the hinge-line. Cardinai angles usually considerably produced and aurieulate, sometimes reflected. Ventral valve very convex and ventricose, depressed in the neighbourhood of the ears, and sometimes showing a shallow mesial depression exteuding towards the frout from the beak. Umbo very prominent, incurred, the area being often "inverted, or brousht under the body of" the shell at right angles to the plane of the marrin" (Billings). The area has a width of about half a line, and is obliquely striated, whilst its outer marsin carries the bases of from three to four snall spines on each side of the umbo, which, however, appear to be very rarely preserved. Dorsal valve concave, following the ventral valve, but with a concavity less than the convexity of the latter. Area of the dorsal valye narrow and almost linear, marked with a row of small transverse de. pressions or pits, which are most obvious near the umbo.

Surface marked with radiating, rounded, simple ribs, which become obsolete on the ears. A few of the ribs bifureate. There are from four to five ribs in the space of one line, and they are separated by interspaces about equal to their own width.

The dorsal valve of this species appears to be extremely rare, Hall having never observed it, and Billings having seen but two tragments. I have only come across a single specimen, which exhibits the interior. This example shows the cardinal process to consist of two nearly parallel and closely contiguous divisions, each of which is bifid at the tip. From the base of the cardinal process is continued a mesial ridge, which dies away towarils the front of the shell; and on either side of this are two diverging ridges which coalesce with the preceding at the base of the cardinal process. The radiating ribs are just as conspicuous in the interior as externally, and are marked by minute remote pustules arranged in a single row on each rib. The muscular impressions cannot be made out.

Chonetes hemispherica is readily distinguished by its general form and its coarse striation. The largest specimen $I$ have seen appears to be about sixteen lines along the hinge-line by twelve lines in length; but average examples are somewhat smaller than this.

Lorality and Formation. - Rare in the Corniferous Limestone of Port Colborne. 


\section{Chonetes arcuata (Hall).}

Chonetes arcuata (Hall), Tenth Report on the State Cabinet, 116.

Chonetes arcuata (Hall), Pal. New York. Vol. IV., Plate XX., Fig. 7.

Shell semi-elliptical, or nearly semi-circular; the hinge-line equal to, or slightly longer than, the greatest width of the shell; the cardinal angles produced into distinct ears, which, however, are usually short and compressed.

Ventral valve extremely convex or ventricose, often with a shallow longitudinal depression, extending from the umbo to near the middle of the shell. Beak prominent and incurved; hinge-line supporting ten to twelve tubular spines, which are directed obliquely outwards, and are rarely preserved. Dorsal valve deeply concave, following the convexity of the ventral valve.

Surface marked by fine rounded strix, which both bifurcate and increase by interstitial addition. From six to seven strix occupy the space of one lire, and the intervals betwcen them are not only narrower than the width of the ribs themselves, but often have the character, especially in partially exfoliated specimens, rather of rows of elongated pits than of di:tinct grooves.

'This species is very closely allied to C. hemispherica in its form and general characts!. It is readily distinguished from the latter by its much more numerous and finer strix.

Locatity and Formation.-Not uncommon in the Corniferous Limestone of Port Colborice.

\section{2.-ČHonetes ACUTI-RADIATA (Hall).}

Strophomena acuti-radiata (Hall), Geol. Report, 4th Dist., New York, p. 171,

Chonetes acuti-radiata (Hall), Tenth Report on the State Cabinet, p. 117.

Choneles acuti-radiata (Hall), Pal. N.Y., Vol. IV., Plate XX., Fig. 5.

Shell semi-elliptical, it width along the hinge-line nearly or more than twice as great as its length ; cardinal angles produced.

Y entral valve convex, but not excessively so, depressed towards the flattened ears, sometimes abruptly arched or bent downwards from the middle towards the margin, so that the marginal portion of the shell forms nearly a right angle with the umbonal region. Sometimes a slight mesial furrow or depression, extending from the beak to the front margin. Dorsal valve, characters of the area, and interior maikings unknown. Surface marked by sub-equal, rounded, or sub-angular radiating ribs, about six in the space of one line, which increase by bifurcation and interstitial addition in proceeding from the beak to the margin. On the c:trdinal extremities the ribs are faintly marked, or obsolete.

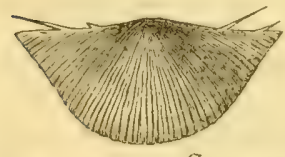

a

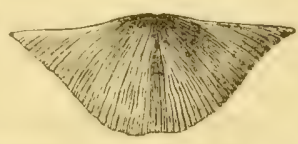

Fig. 25 .

According to Hall, the hinge-linecarries, on each side of the umbo, four or five strong tubular spines, which are obliquely directed outwards; but no traces of these are preserved in the few specimens col. lected by me. C. acuti-radiata is nearly allied to both $C$. hemispherica and $C$. arcuta, Ventral valve of Chonetes acuti-radiata (Hall), natural size uta; but it is distinguished by the dis(after Hall); $b$, Ventral valve of another specimen of the same from proportionate width of the shell along the the Corniferous Limestrone of Ontario, natural size.

hinge-line as compared with the length, the flattening of the cardinal extremities, and the less convexity of the ventral valve. The striation is also fiver than it is in S. hemispherica.

Localty and Frormation.-Rare in the Corniferous Limestone of Port Colborne.

\section{Genus Productella (Hall).}

"Shells having the general form of Productus, but uniformly with a narrow area on each valve, a foramen or callosity on the ventral area, small teeth, and more or less distinct teethsockets. The reniform vascular impression, rising from between the anterior and posterior occlusor muscular impressions, curves gently outwards, and following a curvature somewhat parallel with the margin of the shell to below the middle of its length, is abruptly recurved, and the extremity, turned a little backwards, terminates about half way between the margin 
and the anterior extremity of the nesial septum. The cardinal process, seen from the inner side, is bilobed, and from the exterior side each of these divisions is usually bilobed.

"These shells differ from Strophalosia in the extremely narrow linear cardinal area, greater extension of the hinge-line, more extreme arcuation or ventricosity of the ventral valve in many or most of the species, and especially in the direction and termination of the reniform vascular impressions, which resemble those of Aulosteges, and of some species of Productus. It differs from Produrtus in the constant presence of an area, hinge-teeth, and sockets." (Hall, Pal. New York, Vol. IV., p. 153).

I'roductellu is considered by Hall as a mere sub-renus of Proluctu, but it seems to me that the articulation of the valves by listinct teeth and the presence of a distinct hinge-area are quite sufficient characters to separate Productellu gencrically from Piocluctu. Whether Productella can be kept apart from Strophalosia of King is another matter, the chief characters by which the two are separated being merely questions of degree. In external appearance, however, the shells referred to Productella resemble Productu, much more nearly than do those referred to Strophalosia.

Professor Hall has described many species of Prolluctella from the Devonian Rocks of the State of New York, chiefly from the Hamilton and Chemung groups, but also from the Corniferous Limestone. I have only met with a single form of the genus in the Devonian formation of Western Ontario, and this thoush exceedingly abundant in the Corniferous limestone in several localities, is certainly distinct from any of those recorded by Hall. I shall, therefore, describe it as new, under the name of Productella Eriensis.

\section{Productella Eriensis (Nicholson).}

Shell minute, thick, semi-oval or nearly semicircular, the len th about one-fourth less than the width as a general rule. Hinge-line as wide as, or wider than. the greatest width of the shell; the cardinal ansles rounded, or, more commonly. distmetly auriculate.

Ventral valve excedingly gibbous and ventricose. strongly aud regularly arched from the beak to the front margin, but depressed towirds the cardinal angles. Umbo obtuse, prominent, strongly incurved. Area very narrow and difficult to make out. The cast of the ventral valve exhibits a longitudinal slit extending from the beak abnut one-fourth or one-third of the length of the shell, and indicating that the cavity of the beak was divided by a low mesial partition ("rostral septum"). In front of this slit there is often a horse-shoe-shaped elevation representing the east of the pit to which the divaricator muscles were attached, but this cannot always be made out. On one or both sides of the mesial slit there is also generally a slighter and shallower groove bounding the umbo lateraily; but the general surfice of the cast is quite snooth and not pitted.

Dorsal valve depressed-convex, not gibbous, depressed towards the cardinal angles. When partially decorticated, the dursal valve shows very distinchly from six to eight encentric imbricating lines of growth. In this condition it also exhibits a more or less defined median longitudinal ridge which extends from a small, but constant elongated pit, placed just in front of the umbo, to the front margin-two generally stronger ridges diverging outwards, one on each side of the central line, from the umbo towards the marrin. The beak of the dorsal valve is scarcely promiuent, whilst there is an extremely narrow linear area, and a small car. dinal process.

The interior of the dorsal valve exhibits radiating lines of minute elongated pits, which cover its whole surface or are most abundint in the central portion of the valve, and diminish as the margin is approached. Besides these, on either side of the middle line are two pairs of deep, slightly curved sulci, which extend from beneath the beak to near the margin. 'Those of the innermost pair are most constant, and are placed quite close to the central line of the valve. Those of the outer pair are more variable, and there are often two or three radiating grooves on either side in place of ouly one. Immediately beneath the beak, lastly, are placed two elongated grooves, one on each side, which only diverge slightly from the direction of the hinge-line, and extend only a short distance into the shell. 'These are apparently dental sockets.

The surface of the vental valve is rarely preserved, but appears to be quite smooth; the surface of the dorsal valve exhilits faint concentric strix. No radiatiog strix can be made out; nor are there any traces of spines either on the hinge-margin of the ventral valve or upou the surface of either valve. 
The width of the hinge-line of the ventral valve is two lines, the length about a line and two thirds, and the height about three quarters of a line to a line. The dimensions of the dorsal valve are the same, except that the height is much less. Hardly any departure from these measurements can be observed, even amongst a large number of specimens, but a few individuals are very slightly larger, apd a good many have the proportion of the length to the breadth slightly less, owing to the greater extension of the cardinal angles.
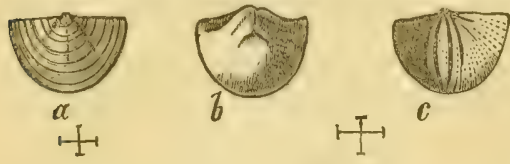

Fig. 26.

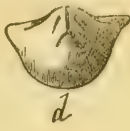

d

Amongst the numerous species of Productella described by Professor Hall from the Devonian Rocks of the State of New York, there are only two, viz., $P$. subaculeata and $P$. Tullia, which have the dorsal valve convex, all the others being

a, Exterior of the dorsal valve of Productella Erriensis, [Nichol- concavo-convex. From these, however,

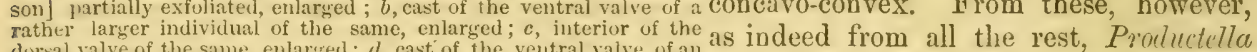
dorsal valve of the same, enlarged; $d$, cast of the ventral valve of an arricnsis is readily distinguished by the niferous Formation.
total a'sence of spines, and by the internal characters of loth valves. There may, in fact, be some doubt as to the reference of this form to Productella at all, and for the posilive decision of this doubt our materials are unfortunately insufficient; since, though I have examined some hundreds of specimens, I have not succeeded in finding one single example in which the characters of the hinge-line and areas are satisfictorily shown. Still the ventral valve, in its great gibbosity, in its extended hince-line, and its produced and depressed ears, is singularly Productoid; and the presence of distinct areas in each valve, and the fact that the valves are articulated by teeth and sockets, would remove the species from Producta, and would seem to warrant its reference to Pinductella. The muscular impressions in the ventral valve, unluckily, cannot be milde out, and consequently no help can be derived from this suurce; whilst the iuterior of the dorsal valve is certainly unlike that of the typical Productella, and in some respects approaches Leptena.

There remain two well known Devonian Brachiopods to which at first sight the present form bears a far from slight resemblance, viz, the Spirifera Urii of Fleming, and the Spirifera (Ambocelia) umbonuti of Conrad, and it may therefore be as well to iudicate the points by which our species is distinguished.

Spirifera Urii (Fleming), is a small suborbicular shell with a very convex and gibbous ventral valve, a prominent and incurved umbo, and a semi-circular flat or slightly convex dorsal valve. The hinge-line, however, is shorter than the greatest width of the shell; the cardinal angles are rounded; the dorsal valve has a shallow mesial furrow which commences near the beak and extends to the front; the ventral valve has a loneritudinal furrow commencing at the extremity o! the beak and extending to the front; and there is a sufficiently conspicuous area. These characters fully distinguish Spirifera Urii from Productella Eiriensis.

Amboccetia umbunutu (Conrad), [Orthis mimlonn, Conrad, and Orthis nucleus, Hall,] is also a small semi-circular Brachiopod, which is very uearly related to Sturiferu brii. It presents a superficial resemblance to Productelle Eviensis, owing to its gibbous ventral valve, and comparatively wide and straight hinge line. It is however, readily distinguished by its very elevated umbo, the existence of a mesial sinus in the ventral valve extending from the beak to the front of the shell, and the presence of a cumparatively large and high area, which extends "conspicuously to the cardinal extremities." The surface also is marked by fine radiating and concentric striæ.

Locality and Formution.- Very abundant in certain beds of the Corniferous Limestone at Port Colborne and Hagersville.

\section{Genus Atrypa (Dalman).}

Shell impunctate and fibrous; surfice usually ribbed and often furnished with imbricating lines of growth often produced into foliaccous expansions; valves articulated by teeth and sockets; the ventral valve often depressed in front, with or without a mesial sinus, its beak iucurved and perforated at the apex by a minute foramen, which is sometimes bounded in front by a deltidium. Dorsal valve convex and often very ventricose, with or without a 
mesial fold; the hinge-plate divided, and supporting two large conical spires which are directed into the hollow of the dorsal valve.

Two species of this genus, viz., A. reticularis (Linn.), and Atrypa spinosa (Hall), (if, indeed, the latter is truly distinct from the former) are known to me as occurring in the Corniferous and Hamilton Formations of Western Ontario.

\section{Atrypa reticularis (Linnæus).}

Anomia reticularis (Linnæus), Syst. Nat., Ed. XII., p. 1132.

Atrypa relicularis (Dalman), Vet. Ac. Handl., Pl. IV., fig. 2.

Terebratula prisca (Von Buch), Uéber Terebratula, p. 71.

Tevebratula (Atrypa) mise (Phillips), Pul. F'rs. of Comuell, \&e., Pl. XXXIII., fig. 114.

Spirigerina reticularis (D'Orbigny), Prodr. de Paléont., Vol. I., p. 99.

Atrypureticularis (Davidson), British Foss. Biachiopodu, Introduction, Pl. VII., figs. 8793, and Part VI., p. 53.

Spirigerina reticularis (McCoy), Brit. Fal. Foss., p. 379.

Atrapu reticuluris (Hall, l'ul. $\Lambda$. Y., Vol. III., Pl. XLII., fig. 1, and Vol. IV., Pls. LI.,-LIII., A.

87.

- Itrypu retirularis (Billings), Cunatiun Joumul, Neu Series, Vol. VII., p. 26t, figs. 84-

(The above list comprises only the most important of the numerous synonyms of this persistent and cosmopolitan species).

Shell exceedingly variable, both in form and dimensions; usually oblong-ovate, with the widest portion of thes shell a little below the hinge-line. Teutral valve usually moderately convex in the vicinity of the beak, flattened towards the sides, and markedly depressed in front, with occasionally a broad but shallow sinus towards the front margin. At other times the anterior depression and sinus are inennspicuous. The beak of the ventral valve small, incurved, and so atpresed to the dorsal beak as to conceal the minute foramen by which it is gerforated. Dorsil valve always convex and uniformly more so than the ventral valve, though sometimes only slightly so; usually very giblons, but becoming slightly concuve towards the rounded cardinal angles, and for the most part without a defined fold corresponding with the sinus in the ventral valve.

surfice covered with small radiating rounded ribs, generally two or three in the width of: a line, irereasing by bifurcation and interstitial addition in proceding from the beaks to the front margin. The radiating rihs are erossed by numerous eonecutric lines of erowth, which usually form distinctly elevated or produced and syuamose lines, and which, near the marcin, are sufficiently close to give the ribs a characteristic nodose appearance.

In the interior of the ventral valve is a broad mesial spoon-shaped depression, which gradually grows shallower in proceeding from the beak to the margin, and which is bounded by two well defined semicircular ridges. This gives origin chiefly to the divaricatur muscles, and gives rise to a corresponding elevation, bounded by two semicireular depressions in the cast of the valve. 'The interior' of the dorsal valve is chiefly occupied by the greatly developed spiral supports of the arms.

Arylu reticuluris ranges from the middle of the Silurian series to the summit of the Deronian, and is a well-known shell both in Europe and North America. In Western Ontario it occurs plentifully both in the Corniferous Limestone and the Hamilton Group. As a rule, the Corniferous examples are of larger size, and have more gibbous dorsal valves than those from the Hamilton series. An average Hamilton specimen has a greatest width of ten lines, its length being the same, and its height being five lines. An average specimen from the Corniferous has a greatest width of thirteen lines. A larger specimen from the same formation, with a more gibhous dorsal valve, has a width of fourteen lines, a length of eighteen lines, and a height of thirteen lines.

Larality and Formarion. - Corniferous Limestone of Port Colborne, Ridgeway, Hagersville, de. Hamilton Group of Widder, and Burtlett's Mills, near Arlona, in the Tomnship of Bosanquet. 


\section{ATrYPA SPINOSA (Häl).}

Atrypa spinose (Hall), Report 4th, Geol. Dist. New York, p. 200, Figs. 1 and 2. Atrypa dumosa (Hall), ibid, p. 271, Fig. 1.

Atrypa spinosa (Hall), Pal. N.Y., Vol. IV., Pl. LIII. A., Figs. 1-14, 18, 24, 25.

(Compare the Atrypa aspera or Atrypa reticularis, var, aspera of Dalman, Phillips, MeCoy and Davidson. Compare also the Atrypa squamosa of Sowerby.)

This species in form and in all its general characters is identical with Atrypa reticularis, (Linn.), but its surface ornamentation is peculiar ard distinctive. The surface is "marked by gtrong, rouuded, radiating costæ, bifurcating at unequal intervals, which are much stronger in the middle of the valve, and become obsolete or appeir as gentle undulations towards the cardinal angles. In the middle of the valves there are about seven or eight of these costre in the space of half an inch. The shell is also marked by strong concentric lamellæ, which are often about a line apart. In perfect shells these lamcllæ, at the crossings of the costæ, are produced into tubular spines, which when worn off, leave the ordinary lamellose surface. The spaces between the lamellie are marked by fine thread like striæ." (Hall, Pal. N.Y., Vol. IV., p. 322).

I have only seen two specimens from the Corniferous Limestone exhibiting the above characters, but these are well marked. I agree with $\mathrm{Hall}$ in thinking that the characters of this shell are sufficiently distinct to entitle it to specific distinction; but if it should prove, as is probable, to be identical with the Atrypa aspera of European authorities, the latter name has the priority.

Locality and formation.-Rare in the Corniferous Limestone of Hagersville.

\section{Genus Spirifera (Sowerby).}

Shell-structure fibrous and impunctate ; form very variable, but typically more or less threesided or quadrate, sometimes oval or sub-circular. Hinge-line straight, mostly as long as or longer than the greatest width of the shell, sometimes shorter. The cardinal angles sometimes obtusely rounded, more commonly produced or extended, sornetimes greatly so. Surface usually with radiating ribs, or smooth, or striated. Generally an elevated fold in one valve and a corresponding sinus on the other. Valves articulated by teeth and sockets; the ventral valve the larger, with a more or less prominent beak, a well-marked area, and a triangular foramen which is sometimes closed by a pseudo-deltidium. Dorsal valve with a narrow area and a wide triangular foramen. Interior more or less occupied by two spirally. rolled limellæ, forming two cones, the apices of which are directed towards the cardinal angles.

A large number of species of Spirifera have been described from the Devonian Rocks of North America. With the exception, however, of the extraordinarily abundant S. mucronctcu, our collections of the species of this genus are very imperfect. I have only been able to satisfactorily identify $S$. varicosa, $S$ duodenaria, s'. rimico tu, S. fimbricta, and $S$. mucronata, -the last from the Hamilton group, and the others from the Corniferous Limestone.

\section{Spirifera mucronata (Conrad).}

Delthyris mucronata (Conrad), Ann. Report on the Geology of New York, p. 54.

Delthyris mucronate (Hall), Geol. Report, 4th District New York, p. 198.

Spirifera mucronata (Billings), Canadian Journal, New Series, Vol. VI., p. 254, figs. 5962.

Shell semi-circular or semi-oval, usually sub-trigonal or triangular, the cardinal angles sometimes truncated, but more commonly acute and extended, often produced into long mucronate extensions. In a few instances, the hinge-line is very little longer than the greatest width of the shell below, but it is generally twice or thrice the length of the shell measured from the beak to the front margin, and iccasionally four, five, or six times as great. The sides of the shell are straight, or curved slightly, and the front margin is straight or concave.

The ventral valve is more convex than the dorsal, though sometimes only slightly so, with a small incurved beak, and a narrow linear area, the height of which, when most 
developed, is only from half a line to three quarters of a line, and is often less. Commencing at the beak and extending to the front of the rentral valve is a well-defined mesial sinus, which is usually shallow and rounded, and is bounded laterally by plications stronger than the rest.

Dorsal valve moderately convex, not so convex as the rentral valve, its beak incurred, but not in contact with that of the ventral valve, its area extremely narrow and linear. Corresponding with the sinus of the ventral valve, there is a prominent mesial fold extending from the beak to the front margin.

Surface marked by sub-angular radiating ribs or plications, usually from eight to twelve on each side of mesial fold and sinus, the outermost not reaching the beak, and the cardinal angles being free from them. The plications are crossed by numerous imbricating zig-zag concentric strix, which become very much crowded together as the margin of the shell is approached, and which, close to the margin, are often interrupted by stronger lines of growth.

The dimensions and form of Spirifich mucromata are excessirely variable-so much so that the extreme terms of the series have all the appearance of being distinct species. The following gives the form and measurements of the leading rarieties of this species as seen in the Hamilton Formation of Ontario, where it is a wonderfully abundant species, and is found in a state of beautiful preservation :-

a. A semi-circular, and very ribbous form, with the cardinal angles acute, but hardly produced, width of hinge-line one inch; length eight lines; height seven lines.

b. A moderately conrex form, with the cardinal angles moderately but not excessirely produced; the general figure of the shell becoming trigonal. Width at hinge-line one inch and seven lines; length, eleven lines; thickness, seven lines. This may be regarded as the normal form of the species.

$\therefore$ A form upon the whole resembling the preceding in outline, but with straighter sides. so that the shell is of a regular triangular shape, the apex of the triangle being truncated at the mesial sinus and fold. The shell is also much thinner owing to the smaller convexity of the valves, and especially of the dorsal valve, which is grently arched near the umbo, but is more or less abruptly reflected all round the margin at about two-thirds of its length from the beak. The cardinal angles are also more extended, increasing the disproportion between the width and length. Wiilth at hinge-line, twenty-two lines; length. nine lines: height, only four lines. This form oecurs not uncommonly in the railway-cutting at Widiler, and can lie traced by insensible gradations into the preceding. just as that graduates into the form first described.

1. Latstly, a form in which the cardinal angles of the shell are immensely produced, the total width at the hinge-line thus eoming to be three, four, five, or eren six times as great as the lensth at the heaks. There are, also, from fifteen to twenty plications on either side of the mesial fold and sinus. Wirth at hinge-line in a small slecimen twenty-two lines; length, seren lines; height, three lines and a quarter. Width at hinge-line in a fully-grown slecimen three inches; length, six lines; height apparently between four and five lines.

Luenlity and Finmutim.- - Very abundant and beautifully preserved in the decomposed shales of the Hamilton group, on the line of the Grand Trunk Railway, near Widder Station. where only the first three of the valieties here described are known to oceur. Also, esmmon in the calcarenus or calcareo-arenaceous beds of the same formation at Bartlett's Mills, near Arkona, in the Township of Bosanquet, where the extremels mucronate rariety is the chiet. or only; one to oceur. Also, in the Corniferous Limestone of Port Colborne an! Ridgeway.

\section{Spirifera varicosa (Hall).}

Spirifer varicosus (Hall), Tenth Report on the State Cabinet, p. 130. 63,64 .

Spirifera varicosa (Billings), Canadian Journal, New Series, Vol. VI., p. 255, Figs.

Spirifera varicosa (Hall), Pal. New York, Vol. IV., Plate XXXI., Figs. I-4.

This species is rery closely allied to spirifiru mumbotu, with which it agrees in its general form and its surface characters. The chief point by which s. earios is distinguished is the comparatively great height of the ventral area, and the prominence of the beak of the rentral valve. Thus in $S$. mucromutu, the ventral area rarely exceeds half a line in height, whilst in $S$. "rriros it may hare a height of as much as two lines and a half. The latter species is also in 
general a smaller species than the former. I have only seen a few detached valves of this species in the Corniferous Limestone.

Locality and Formation.-Corniferous Limestone of Port Colborne and Hagersville.

\section{Spirifera duodenaria (riall).}

Delthyris duodenaria (Hall), Geol. Report, 4th Dist., New York, p. 171.

Spirifer duodenaria (Hall), Catalogue in Report on State Cabinet. $65-67$.

Spiriferu duodenariu (Billings), Canadian Journal, New Series, Vol. VI., p. 256, Figs.

Spiriferc dundenuriu (Hall), Pul. New York, Vol,, IV., p. 189, Plate XXVII., Figs. 13-16; Plate XXVIII. Figs, 24-33.

Shell semi-circular, or sub-triangular, the hinge-line equal to the greatest width of the shell; the cardinal angles rounded or acute, rarely pointed. Ventral valve slightly more convex than the dorsal, depressed towards the cardinal extremites, with a prominent beak, a narrow area, and a mesial sinus of moderate width and depth. Dorsal valve moderately convex, with a narrow and prominent mesial fold corresponding with the ventral sinus, its area linear. Surface exhibiting six or seven strong rounded simple ribs on each side of the mesial fold and sinus. The ribs are broad and are separated by rounded intervals, and they decrease in size in proceeding from the middle line towards the cardinal extremities.

Most examples show a completely smooth surface, but the shell, in perfect examples, is marked by "lamellose concentric stria, giving a papillose or sub-fimbriated aspect at their junction." (Hall).

Spirifurt duodenaria is not uncommon in the Corniferous Limestone of Western Ontario, and is usually readily recognised by its large rounded ribs and generally smooth surface. It varies a good deal in its dimensions, average specimens having a width of eight or ten lines along the hinge-line, and a length of five or six lines. ville, \&c.

Locality and Formation.-Corniferous Limestone of Port Colborne, Ridgeway, Hagers-

\section{Spirifera raricosta (Conrad).}

Delthyris rericostu (Conrad). Juer. Acad. Nat. Sci. of Philadelphia, Vol. VIII., p 262, Pl. 14, Fig. 18.

Delthyris undulatus (Vanuxem), Geol. Repert, Thind Dist. New Iorti, p. 132, Fig. 3. 71-73.

Spiriferu rarienstu (Billings), Cunudum Jourmal, New Series, Vol. VI., p. 25s, Figs.

Spirifere raricostu (Hall), Pal. N. Y., Vol. IV., Pl. XXVII., Figs. 30-34, Pl. XXX., Figs. 1-9.

Having only obtained a few imperfect specimens of this fine species, I shall content myself with simply noting its existence, without giving its description.

Sprifure rerricostu is at once distinguished from the other Syirifere. of the Corniferous Limestone by its possession of from two to four strong, prominent, rounded or sub-angular plications on each side of the mesial fold and sinus. The ventral valve also is very gibbous above, and the beak much elevated, whilst the cardinal angles are rounded.

Locclity and Formution. - Rare in the Corniferous Limestone of Port Colborne.

\section{Spirifera fimbriata (Conrad).}

Detthyris fimiriate (Conrad), Jomern. Acal. Nat. Sci. of Phitulelphia, Vol. VIII., p. 263. $68-70$

Sprififerce fomlinitu (Billings), Cunulien. Joumul, New Series, Vol. VI., p. 257, Figs.

Spirifera fimbriata (Hall), Pal. N. Y., Vol. IV., Pl. XXXIII., Figs. 1-21.

Shell transversely oval, bi-convex, the hinge-line shorter than the greatest width of the shell, and the cardinal angles rounded and not produced. Ventral valve gibbous in the upper half, the beak small but jrominent, incurved over the area, the latter being high and concare. The sinus is well-defined, sometimes rounded sometimes angular, and extending from the beak to the front of the shell, with a variable number (usually three or four, but sometimes eight or nine) of low and obscure plications on each side. Dorsal valve moderately gibbous, 
with a minute beak and a rounded, mesial fold, and a narrow sub-linear area. Plications obscure, becoming obsolete towards the cardinal angles, and dying away in the neighbourhood of the hinge-line. Surface marked with shallow concentric furrows separated by interspaces which are studded with elongated tubercles. There are from three to four or more furrows in the space of two lines, and from five to eight elongated tubercles in the space of one line transversely. In casts of the exterior, the elongated tubercles are represented by narrow elongated pits arranged in concentric bands.

Spiriferce fimliriata not uncommonly attains a width of an inch and three quarters by a length of thirteen lines, but arerage examples are smaller than this. It is readily recoguised by its comparatively short hinge-line, its rounded cardinal angles, its obseure plication, and its surface ornamentation.

Lnculity and Formation.-Corniferous Limestone of Port Colborne. Also, according to Mr. Billings, in the Hamilton Shales of Bosanquet.

\title{
Genus Orrtina (Davidson).
}

Shell small and resembling that of Spirifere in its general form. Shell-structure punetate. Valves very unequal; the rentral valve elevated and pyramidal in shape; the area very high, with a long narrow foramen, closed by a pseudo-deltidium ; the dental lamella converging from the margins of the foramen, and uniting to form a mesial plate or septum, which divides the eavity of the rentral valve into two compartments. Dorsal valve nearly flat or moderately conver. Spires well-developed, and resembling those of s'pirifure and spritferina.

The genus ('yrtinn is closely allied to Cytin (Dalman), and Syiriferiun (D'Orbigny), and has also neai' relationship with the gemus suivifm. 'Two species have been recorded by Mr. Billings, as occurring in the Deronian Rocks of Western ()utario, namely Cyrtium rostrutu (Hall), from the Corniferous Limestone, and (. IImniltumensis (IIall), from the Hamilton group. 'The latter is a common species, but the fer examples of 'irtinn, which I have seen from the Corniferous Limestone are too imperfect to admit of specific determination.

\section{Cyrtina Hamitonensis (Hall).}

\author{
Cyrtia Humiltonensis (Hall), Tenth Report on the State Cabinet, p. 166. \\ 80-82.

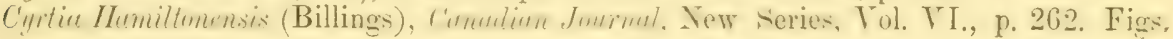

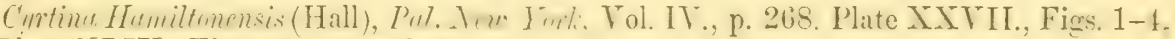
and Plate XLIV., Figs. 26-33, and 38-52.

"Shell more or less triangular or sub-pyranidal ; hinge-line cyual to the greatest width of the shell; proportions of leugth, brealth, and height variable. but frequently the width is equal to the length of the rentral valve. and the height of area is equal to the length of the dorsal valve; surface plicate. Tentral ralve quadrilateral in outline, obli,puely sub-pyramidal, most prominent at the leak, which is very variable in elevation and straight or a little arched over the area, and not unfrequently attenute and distorted or turued to one side; mesial sinus wide and stronely defined, rounded or sub-angular in the botton; area variable. large and elevated. plane or areuate in different dewrees, with the lateral margins ancular. distinctly striate in both directions; fissure narrow, closed by a conves pseudo-deltidium. which is perforated above by an oval or uarrowly orate foramen. Dorsal valve depressed, convex, with a broad, more or less prominent mesial fold, which is bounded by broader furrows than those between the plications, and is sometimes extremely elevated in front; the beak scarcely rising above the hinge.line; area narrow. linear, bnt quite distinct; surface marked by about six to eight (rarely one or two more) simple rounded plications on either side of the mesial fold and sinus, and these are crossed by very fine concentric lines of gromth, which at intervils: became crowded and sub-imbricate, especially towards the margins of older shells. The finer surface marking is minutely granulese or papillose, and the shell-structure is distinctly punctate. In some of the larger individuals there is an obscure elevation on each slope of the sinus, resembling an obsolete plication. The longitudinal median septum extends for more than half the length of the rentral valve, and is continued into the eavity beneath the pseudo-deltidium. These features are shown in casts and in transverse sections of the ralre. 
The dorsal valve shows a double or bilobed cardinal process, with the strong crural bases supporting spiral arms which are directed into the two compartments of the ventral valve, and making numerous turns, terminate in the rostral part of the shell." (Hall, Pal. New York, Vol. IV., p. 268).

I have little to add to the above detailed description of this pretty little Brachiopod by Professor Hall. Cyrtina Hamiltonensis occurs commonly, and in a state of beautiful preservation, in the Hamilton Formation of Ontario, and I have also seen casts apparently belonging to this species from the Corniferous Limestone. Many of the Hamilton specimens have a flat area without an incurved beak, and thus come to agree with Hall's Cyrtina IIamiltonensis var. recto : but I am of opinion that this variety is by no means sufficiently distinct to deserve a separate designation. In fact there appear to be three chief variations as regards the above mentioned points within the limits of this mutable species, and all three are connected together by transitional forms. In one of these, the area is nearly or quite plane, and is directed forwards almost or quite at right angles to the plane of the dorsal valve or hingeline, whilst the beak is very slightly elevated, and little or not at all incurved. In these forms the thickness of the shell (measured at right angles to the hinge-line, instead of from the hingeline to the beak) is proportionately very great. In other forms, the hinge-area is moderately elevated and forms a very obtuse angle with the plane of the dorsal valve, whilst the beak is moderately prominent and is incurved. These forms may be regarded as keing the normal form of the species. In other examples, again, which are otherwise undistinguishable from the preceding, the beak of the ventral valve is extraordinarily elevated and prominent, and is markedly incurved; whilst the plane of the arcuate area approximates to the plane of the dorsal valve and forms with it an acute angle. The result of this is that the thickness of the shell measured at right angles to the hinge-line becomes very much smaller than in the preceding forms. The last mentioned form appears at first sight to be a distinct species from those with a flat area directed perpendicularly to the plane of the dorsal valve, but I am satisfied that all the above mentioned varieties may be safely brought under the limits of a single species.

The dimensions of this species vary considerably. In an adult example of the variety in which the area is flat and perpendicular to the plane of the dorsal valve, the width of the hinge-line is ten lines, the length of the dorsal valve is five lines, the length of the ventral valve is eight lines, the height of the area is five lines, and the thickness of the shell measured at right angles to the hinge-line is also five lines, and is thus equal to the height of the area. In another also fully-grown example, with a very oblique area, the width of the hinge-line is nine lines (the cardinal angles being much more rounded than in the preceding), the length of the dorsal valve is six lines, the length of the ventral valve is ten lines, the height of the much curved area is nearly four lines, and the thickness of the shell at right angles to the hinge-line is only three lines and a half, and is thus much less as compared with the size of the shell than in the preceding.

Small examples as well as large are not uncommon, showing the variations in the plane of the area here described, proving that the latter are not due to rariations of age.

Locality and Formation. - Common in the Hamilton Shales of Widder, in the Township of Bosanquet.

\section{Genus SpIRIGERA (D'Orbigny).}

Shell variable in form, with convex valves which are articulated by teeth and sockets; beak of the ventral valve short and incurved, and truncated by a small foramen, which is in contact with the beak of the dorsal valve, or is separated from it by a deltidium of two pieces ; a mesial fold and sinus present or absent; surface smooth or striated, with numerous concentric lines of growth; dorsal valve without any mesial septum, but with spiral cones, the extremities of which are directed outwards towards the lateral margins of the shell.

It seems unnecessary to enter here into the controversy which has been carried on as to the genera Spirigere, Athyris, Meristu, and Meristella, or to attempt to decide which of those divisions can be retained, and which must be rejected. It is sufficient to state that I shall here adopt the arrangement proposed by Mr. Davidson, and followed by Mr. Billings, in which Spirifere is made to include shells without a mesial septum and with the beak of the ventral valve perforated by a conspicuous foramen, whilst Athyris includes shells with an imperforate beak (in the adult state at any rate), and generally with a mesial septum. Adopting this 
arrangement, some of the shells referred by Hall to Meristella will be considered here under the head of Spirigera, whilst others will come under Athyris.

The species of Spirigere, as here understood, which hare come under my notice in the Devonian Rocks of Ontario, are three in number, viz. : st. spirifernides (= S. concentrica?), S. scitula, and S. rostrata.

\section{Spirigera spiriferotdes (Eaton).}

Terebratula spiriferoides (Eaton), American Jonal of Science, Vol XXI., p. 137. Atrypa concentrica (Conrad), Annual Report on Pal. New York, p. 111. Atrupa concentrica (Hall), Report Fourth Dist., New York, p. 198, Fig. 5. Spirigera spiriferoides (Hall), Tenth Report on the State Cabinet, p. 153. Sprivigera encentriea (Billings), Cunadian Jummal, New Series, Vol. VT., p. 145, Figs. 52, and $54-57$.

Athyris spiriferoides (Hall), Pal. New York, Vol. IV. Plate XLVT, Figs. 5-31.

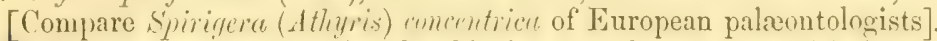

Shell transversely sub-oval, sub-orbicular, or sub-quadrate, with its greatest width near the middle, slightly truncated anteriorly, or more commonly having the front margin produced into a tongue-shaped rounded projection. Hinge-line very short, the cardinal extremities rounded off. Both valves convex, but not excessively so ; the rentral ralve with a shallow mesial sinus which dies out towards the beak; the dorsal valve with a corresponding mesial fold. The beak of the ventral valve incurved, and perforated by a small but conspicuous foramen. Dorsal valve more convex than the rentral, with a suall rounded beak which is concealed beneath that of the ventral ralve. Surfice"marked by close-set concentric lines of growth, which are often produced into imbricated thiu lamellar, and which are always more crowded towards the front margin of the shell.

The interior of the rentral valve exhibits two strone dental lamelle, extending to the base of the rostral carity, where the muscular imprescions commence. The interior of the dorsal valve exhibits a strong curdinal process, with elerated socket-mirgins behiud, and a narrow elliptical muscular impression which is "divided by a low median erest" (Hall). The spires show about fifteen turns each.

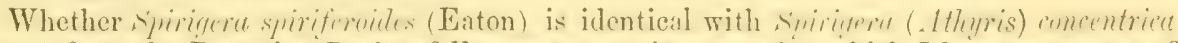
(Bronn,) from the Devoniau Rocks of Europe or unt, is a quetion which I hatre no means of deciding, not having at present aceess to authentie specimens of the latter. I should, howerer, be strongly inclined to think that the two forms, as helieved by Ie Terneuil, Sharpe, Billings, and others, are in reality identical: though, in defereuce to the viems of I'rofestor Mall, I have retained our form as a separate species. In any ease. cren sup posing the two to be the same, the name of spirifirmiles will have to be retained, as having the priority over that of concentrica.

S. spirifernides is of rare oceurrence in the Corniferons Limestone. but is found eommonly in the Hamilton group. Our specimens present no s ecial peculiarity except that, without exception, so far as I have seen, they are smaller than those from the same formations in the State of New Tork. Thus, the larcrest specimen in our collection has only a width of nine lines, and a length of eight lines; whereas specimens from New York sometimes have a width of nearly an inch and three-quarters, and a length of an inch and a half or more.

Lurelity and Furmution.-Corniferous Limestone, Hagersville: Hamilton Group, Widder. and Bartlett's Mills near Arkona, in the Township of Bosanquet.

\section{SPIRIGERA rostrata (Hall).}

Atrype metrute (Hall), Report on the Fourth Genl. Dist. New York. p. 202, Fig. 3. $43-44$.

Atheyris (?) rostrutu (Billings), Cunutiun Jommul, New Series, Vol. V., p. 281, Figs.

Meristella rostrata (Hall), Pal. New Yor\%, Vol. IV., Plate L, Figs. 13-17.

Shell small, ovate or sub-trigonal, sometimes subattenuate above. Both valves cnurex, the ventral scarcely more so than the dorsal. Ventral ralve niost convex above the middle, usually with a shallow rounded mesial siuus in front, which, however. is sometimes almo-t obsolete; the beak prominent, incurved over that of the dorsal valve, but not in contact with it, and perforated by a conspicuous foramen. Dorsal vilve regularly convex, sometimes with 
an obsure mesial elevation in front, corresponding with the sinus of the ventral valve; the beak incurved, and buried beneath that of the ventral valve. Surface with numerous very delicate concentric lines of growth, which become crowded together and conspicuous towards the front margin.

This species is somewhat variable in shape; some specimens have their greatest width a little in front of the middle of the shell; but others (and these are perhaps the commonest) have the greatest width at about two-thirds of the distance from the beak, or even nearer the front than this, the shell thus assuming a sub-triangular form. Average specimens have a length of six lines, a width of five lines, and a depth of about three lines.

In the most perfect specimens I have seen, the foramen is large and conspicuous, and is perforated in the summit of the beak of the ventral valve, so as to look upwards.

Locality and Formation.-Rare in the Corniferous Limestone of Port Colborne. Hamilton formation of Widder.

\section{Spirigera scitula (Hall).}

Atrypa scitula (Hall), Report on the Fourth Geol. Dist. New York, p. 171, Fig. 1.

Athyris (?) scitula (Billings), Canadian Journal, New Series, Vol. V., p. 278, Figs. 35, 36 (r.cet. exclusis).

Meristella scitula (Hall), Pal. New York, Vol. IV., Plate XLVII., Figs. 34-38.

Shell ovate, both valves convex, the ventral valve the most so, somewhat compressed towirds the front. Ventral valve with a prominent beak, which is incurved over that of the dorsal valye, and is perforated by a conspicuous foramen. Dorsal valve most convex above the middle, depressed towards the front, with a small beak, which is buried beneath that of the dorsal valve. Surface marked by fine concentric strix. Length of an average example one inch; width, nine lines; depth, six lines.

I have only one well preserved example of this species, and am therefore, not prepared to discuss its affinities. Hall's species certainly seems to me to be identical in part with that figured by Mr. Billings. The Charionella circe of Mr. Billings appears to me to be quite distinct, though it is asserted by Hall to be identical with his Meristella scitulu.

Lnculity and Formation.--Rare in the Corniferous Limestone of Port Colborne.

\section{Genus_Athyris (McCoy).}

Shell variable in shape, the valves unequally convex, with or without a mesial sinus ind fold, articulated by teeth and sockets. Beak of the ventral valve incurved, usually overly.. $\mathrm{g}$ and in contact with the beak of the dorsal valve, not perforated by a foramen, or with tic foramen concealed when fully grown. "In the interior of larger or ventral valve the dent:1] plates are fixed to and along the sides of a longitudinal prominence or convex arch-shaped plate, which extends to less than a third of the length of the shell, with its narrow end fitting into the extremity of the beak, and its lateral diverging edges to the bottom of the valve.

The interior of the smaller or dorsal valve is partly divided by a large, deep longitudinal septum, which extends from the extremity of the umbo to about two thirds of the length of the shell, supporting at its origin the hinge-plate, which is divided into two portions by a narrow gradually widening channel; to the socket ridges are affixed the spiral cones, the extremities of which are directed towards the lateral margin of the shell ; on either side of the septum are seen two muscular scars formed by the adductor" (Davidson, British Fossil Brachiopoda, General Intraduction, p. 85.)

Acepting the above definition of the genus Athyris, there are only two forms which have come under my notice in the Devonian Rocks of Ontario, which appear to be referable to this genus, and the position of one of these somernht doubtful. The forms in question are Athyris nes'stri (Conrad sp. = A. cletre, Billings), and A. Muic (Billings), of which the last is referred by Hall to the genus Spirifera.

\section{Atilyris nasuta (Conrad).}

Atrypa nusutu (Conrad), Ann. Report on the Palæontology of New York, p. 18.

Meristella nasuta (Hall), Thirteenth Report on the State Cabinet, p. 93.

Meristella elissa (Hall), Fourteenth Report on the State Cabinet, p. 100. 
Athyris clara (Billings), Cunudian Journal, New Series, Vol. V. p. 274, Figs. 29-32.

Meristella nasuta (Hall), Pal. New York, Vol. IV., Plate XLVIII., Figs. 1-25.

"Nearly smooth, ovate or" sub-rhomboidal; greatest width, about the middle; a short. linguiform projection in the middle of the front margin ; both valves convex; ventral valve the larger, with its beak strongly incurved. Length from one to two inches; width equal to, a little less, or a little greater, than the length. The ordinary size is about one inch and a half in length.

"The ventral valve is strongly and smoothly convex, the outline evenly arched from beak to front, more abruptly curved above than below, the umbo prominent, the beak rather small, neatly rounded at the sides, and elosely inciurved. The linguiform projection in the middle of the front margin is often a simple extension of a portion of the shell, without a sinus, but occasionally there is either a short, shallow depression, or a narrow rounded mesial fold, which seldom, however, extends towards the beak more than three or four lines. The upper half of the dorsal valve is sometimes evenly convex, but in general an indistinct, more or less broadly rounded carination, can be traced from the umbo along the middle to the frout, where it becomes abruptly elevated into a short, prominent, rounded fold, which extends into the linguiform projection. On each side of the median line, this ralve is sently convex, and often exhibits a rather flat slope to the lateral margins. The beak is strongly incurved, and appears to be deeply buried in the cavity beneath the umbo of the ventral valve.

"If a line be drawn acros; the shell at mid-length, and another at one-fourth the length from the front, the greatest width will be founil to range between the two. Many of the specimens are obtusely angular at the sides, and in such the margins above and below the angles are somewhat straight, the upper two sides converwing to the beak, and the lower two to the linguiform extension in front, giving to the shell a rhomboidal instead of an ovate outline.

"At first sight, the surfice appears to be smooth, with a few concentric squamose lines of growth. On closer examination, numerous indistinct, radiating lines may be seen. Of these there are from two to four in the width of one line, and they sometimes appear to lie beneath the surface of the shell. In very perfect specimens, the surfice exhibits fine concentric strix, from ten to fifteen in the width of one line, and these are most distinet towards the front margin.

"Beneath the beak of the detached ventral valves, there is a wide, triangular foramen, not visibie when the valves are united. The inside of the beak is entirely hollowed out into a deep pit or channel, which opens directly into the eavity of the shell. The impressions of the divaricator muscles occupy part of a sub-t ciangular space, the upper angle of which is situated just where the excavation beneath the beak open; out into the visceral earity. The lower side of this space is nearly straight, and the two lower angles rounded. The lateral margins of the space are usually sub-parallel in the lower half, while in the upper half they approach each other, and meet above to form the upper angle. In some specimens the space is more nearly triangular, and it would appear, therefore, that its form is a little variable. The length of the space is about one-third the whole length of the ventral valve, and its width at the lower margin a little less than its leugth. The lower marnin is situated a little above a line drawn across the shell at mid-length. The lower three-fourths of the space is striated longitudinally. and divided into two equal portions by an obscure median groove.

"On each side, at the base of the foramen, there is a short, stout tooth. The dental plates below the teeth extend but a short distance into the risceral carity, when, becoming suddenly much diminished in height, they form a low ridge along the upper margin of the muscular space. The upper part of the muscular space is deeply excavated into the substance of the shell, which is very thick and solid in the rostral half" (Billings).

There is not much to add to the above puoted full deseription of this common Corniferous species by Mr. Billings; but there are a few points which may be noted. The nasute or linguiform extension of the front of the rentral valve, and the corresponding fold on the dorsal valve, are only fully developed in adult examples. Hence in young examples, the fiont of the shell may exhibit nothing more than a hardly pereeptible undulation. Small specimens are also proportionately more circular. The beak of the rentral valve is imperforate, apparently at all stages of growth; but there is a triangular fissure beneath the beak, which by the incurvation of the beak is entirely closed in the perfect shell, and which can only be seen in the detached valve.

Casts of the interior of the ventral valve of this species are extremely common in the 
Corniferous Limestone, and present a very characteristic appearance. The umbonal region of the cast exhibits the filling up of the rostral cavity, in the form of a sub-cylindrical or tongueshaped projection, which is usually grooved on its upper surface, and which is bounded laterally by the deep fissures left by the dental lamellæ. In front the cast of the rostral cavity passes into a great hump or abrupt prominence formed by the cast of the muscular impression. The umbonal slope of this prominence is smooth, and has a median ridge running into the rostral cast ; and the front slope is conspicuously striated with longitudinal strix, and often divided into two halves by a mesial ridge.

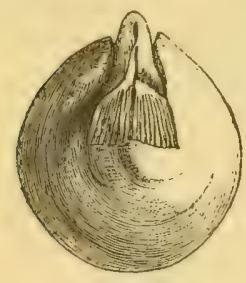

$\alpha$

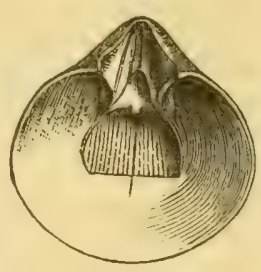

6

Fig, 27.

a. Cast of the interior of the ventral valve of Athyris nasuta (Conrad), from the Corniferous Limestone (Original); $b$, Interior of the ventral valve of the same (after Billings).

"The interior of the dorsal valve shows a strong cardinal process, with a shallow spoon-shaped depression in the centre, margined by deep teeth sockets. The muscular area is elongate-ovate, broader above, and divided through the centre by a thin elevated septum. . . . The crura apparently bend downwards from near their origin; thence recurving, they follow very closely the contour of the dorsal valve, making thirteen or more turns in an individual of medium size. Spires, slender and simple" (Hall, Pal. New York, Vol., IV., p. 301). Hagersville.

\section{Athrris (?) MaIA (Billings).}

Athyris Maia (Billings), Canatian Journal, New Series, Vol. V., p. 276, Figs. 33, 34.

(?) Spirifera Maia (Hall), Pal. New York, Vol. IV., Plate XLIII., Figs. 6-13.

Shell broadly ovate, or sub-rhomboidal ; valves convex, the ventral valve most so. Ventral valve strongly convex, exceedingly gibbous in the umbonal region, the beak prominent and strongly incurved, but not touching the surface of the dorsal valve ; a shallow rounded mesial sinus extending from the beak to the front margin, where it is produced into a linguiform extension. Dorsal valve moderately convex, with a small beak, and a rounded mesial fold which sometimes extends to beak or sometimes falls short of this point. Hinge-line short and straight, the cardinal angles rounded. Surface nearly smooth, with a few lines of growth, and in well preserved specimens, numerous fine and close-set concentric striæ.

According to Billings, there exists "a short false area" beneath the beak of the ventral valve, a feature which our specimens do not enable me to confirm, as the space below the incurved beak is generally concealed by adherent matrix.

The dimensions of an individual of medium size are as follows:-Length, one inch and a quarter; greatest width, fourteen lines, at a point a little in front of the middle; depth, ten lines. Larger individuals than the abuve are of by no means uncommon occurrence.

Hall has described and figured (loc. cit.) under the name of Spirifere Maica, a shell which he believes to be identical with Athyris Mata of Billings, to which it presents a strong resemblance in its general shape. According to Hall, Spirifera Maice has a narrow cardinal area, which is sometimes hidden by the beak, whilst there exists a moderate but conspicuous fissure of a subtriangular shape beneath the beak of the ventral valve. Neither of these features are alluded to by Mr. Billings in his description of Athyris Mraia, nor have I succeeded in detecting either a hinge-area or a fissure in any of the specimens which have come under my own notice. I am disposed to believe, therefore, that the Spiriferc Mluic of Hall is distinct from the present species, a view which is further borne out by the apparently much greater dimensions of the latter; though on this point I can only judge by Professor Hall's figures, and by his statement that the shell of Spiriferc $1 T$ cric is "below the medium generic size," which is certainly not true of Athyris Mfcic. At the same time, in the absence of any definite knowledge of the internal characters of Athyris Maic, beyond the general statement, by Mr. Billings, that its internal structure resembles that of $A$. nasute, $(=A$. clara $)$, it is perhaps hardly safe to assert positively that it belongs to the genus Athyris.

Locality and Formation. - Corniferous Limestone of St. Mary's (Collected by Mr. Hinde). 


\section{Genus Retzia (King).}

The typical species of this genus may be considered as in some respects related to the Rhynchonellide, but more closely to the Spiriferide, and in particular to the genus Spirigere. The shell is in weneral small, and somewhat similar in form to lihynchonelle or to Terctrutulu, from both of which it is distinguished by the possession of calcareous spires. The shell-structure, unlike that of Spirifer $a$, is punctate ; but there is not an extended hinge-line, and there is either no true area or a small one. The beak of the ventral valve is perforated by a small foramen, and the surface is usually ornamented with radiating strie or ribs. The aftiuities of this genus are obscure, and it is uncertain what forms should properly be referred to it. Only one Brachiopod, viz.: Retsin Eugenia, (Billings), has been referred to this genus amongst the forms hitherto discovered in the Devonian Rocks of Ontario, and in the absence of any certain knowledge as to its internal structure, it cannot be said that this reference is free from doubt.

\section{Retzia (?) Eugenia (Billings).}

Retzia Eugenia (Billings), Cunadiun Journal, New Series, Vol. VI., p. 147, Fig. 58.

"Shell small, sub-globular, with from ten to twelve strong augular ribs on each valve. Ventral valve convex, most prominent on the upper half, a slight mesial depression the width of three or four of the ribs in the lower half; beak elevated, incurved, but not in contact with the umbo of the dorsal valve, perforated at the point; a flat solid deltidium or area beneath the aperture. Dorsal valve rather strongly and uniformly convex, most prominent along the middle, where slight indications of a mesial fold are evident; umbo swall, rounded; beak buried beneath the lower edge of the deltidium or area of the rentral valve" (Billings).

Arerage individuals appears to have a length of about four lines, with a width of about the same or slightly less; but larger and smaller examples are not unknown.

I have seen only a few detached valres of this speeies, and can offer no opinion as to its real affinities. By Professor IIall it is considered, with some doubt, as being identical with his Trematospira giblesa (Pul. Nex Yur, Vol. IV., P. 272) ; but it is considered by Mr. Billing to be distinct.

Locality and Formatim. - Rare in the Corniferous Limestone of Port Colborne.

\section{Genus Leiorhynchus (Hall).}

"The shells of this genus are orate, eireular, or transser;e, with ralves unerually contex, and marked by a median sinus and fold in the rentral and dorsal valves respectively. The surface is plicated by rounded bifureating plicatious which are always more conspicuous on the mesial fold and sinus, whilst they often become obsolete on the lateral portions of the shell ; concentrically marked by strong lines of growth. Substance of the shell fibrous, usually thin. Valves articulating by teeth and sockets; the apex of the ventral valve perforate at some period of its growth, the lower side being completed by deltidial plates. On the interior of the ventral valve, two short direrging dental lamella extend into and are joined to the sides or bottom of the rostral cavity ; the muscular impression occupies a narrow triangular or ovate-triangular space, below the dental lamellae. The dorsal valve has a well defined septum, often reaching kelow the middle of the valve, and fivided above, leaving a triangular or spoon-shaped depression. The hinge-plates are uarrow, strong processes, with sockets embracing the teeth of the opposite valve" (Hall, Pal. New York, Vol. IV., p. 355).

I am not in the position to pronounce any opinion as to the validity of the genus Lciurhynchus, or as to the propriety of separating it from Rhunchonellu, to which it is certainly most closely allied. In the meantime, I shall accept it for the reception of the following species from the Hamilton Group; several allied species haring been described by Professor Hall under this title from the Hamilton and Chemung Formations.

\section{Leiorhynchus multicosta (Hall).}

Leimhynehus multicustu (Hall), Thirteenth Report on the State Cabinet, p. 85. Rhynchonella (?) Laura (Billings), Cunudian. Journul, New Series, Vol. V., Figs. 26-28. Leiorhynchus multicostre (Hall), Pul. New York, Vol. IV., Plate LVI., Figs. 26-40. 
Shell ovate, the length and greatest width being nearly equal, or the width greater than the length in young or in compressed specimens. The greatest width is placed near the front of the shell, the sides curving gently from the beak for about two-thirds of the length, and then being bent abruptly inwards. Ventral valve convex, most elevated in the umbonal region, curving to the sides, with a broad shallow mesial sinus which is occupied by from three to six plications. Beak of the ventral valve small, incurved, and in contact with the umbo of the dorsal valve, with a minute circular foramen at its apex. Dorsal valve more convex than the ventral, most gibbous a little above the middle, with its central portion elevated into a mesial fold, which corresponds with the ventral sinus, and is occupied by from three to six plications. Beak buried beneath that of the ventral valve. Surface marked with rounded or sub-angular plications, of which those on the mesial fold and sinus bifurcate, whilst all are obsaure or obsolete towards the beaks. Concentric strix and lines of growth are also present.

An apparently average specimen has a length of ten lines, and a greatest width of ten lines and a half, with a height of six lines. A smaller individual has a length of seven lines, a greatest width of seven lines and a half, and a height of three lines and three-quarters.

According to Hall, the dorsal valve possesses a median septum which reaches more than half the length of the shell, and is divided above, so as to leave a triangular pit. There can be no question as to the identity of Rhynchonella (?) Laura. (Billings), with Hall's Leiorhynchus multicostr. All the specimens of this species that I have seen, have the greatest width slightly in excess of the length, though Hall considers the two diameters to be normally nearly equal. The species is readily recognised by its general form, its rounded plications, becoming obsolete towards the beak, and not interlocking at the margins of the valves, its mesial fold and sinus, and the perforated beak of the ventral valve.

Lnculity and Formution. - Hamilton Group, Widder, Township of Bosanquet (Collected by Mr. George Jennings Hinde).

\section{Leiorhynchus Huronensis (Nicholson).}

Shell elongate-ovate, the greatest width being from one-sixth to nearly one-fifth less than the length, whilst the greatest width is placed nearly about the middle of the shell. Ventral valve convex, very gibbous in the umbonal region, abruptly curving to the sides, and depressed from about the middle to the front margin of the shell. A very broad and exceedingly shallow mesial sinus, which is obsolete near the beak, but occupies almost the whole front margin of the shell, and supports about five low rounded plications. Beak of the ventral valve large, prominent, and incurved, apparently not perforated by a foramen, and in close contact with the umbo of the dorsal valve. Dorsal ralve convex, strongly curved towards the sides, its centre occupied by a broad mesial fold, which corresponds with the rentral sinus; and carries five rounded plications. Margins of the fold and sinus more or less distinctly interlocking. Beak of the dorsal valve buried deeply beneath that of the ventral valve. Surface marked with rounded plications, which are very obseure, except upon the fold and sinus, and which become nearly obsolete in the neighbourhood of the beaks. The plications are crossed with very fine concentric strix, and with strong and very well marked lines of growth which become close-set and imbricating towards the margin of the valves.

The dimensions of a large individual are :- length, one inch ; greatest width, ten lines ; height, eight lines. A smaller and nar:orver individual has a length of eleven lines, a greatest width of eight lines, and a height of six lines.
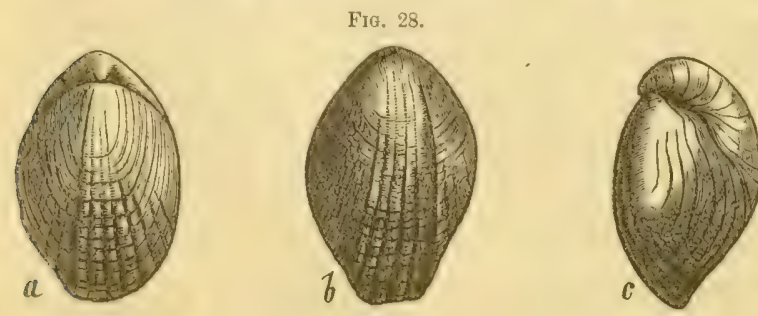

There is no doubt as to the entire distinctness of this from the preceding, though there may be some question as to its reference to Leiorhynchus ; since Hall states that the fold and sinus in this genus never interlock, which they certainly do in some examples of this species. In other respects, however, there is a close general resemblance between this and

Lciomlunchus IIuronensis. (Nicholson); $a$, Dorsal view; $b$, Ventral L. multicoste, especially as regards view ; $c$, Side view of a large individual. Fron the Hamilton Group. the surface-characters, and I do not 
think the two species can be generically separated. L. Huronen.sis is distinguished from $L$. multicoste by its much more elongated and contracted form, the greater convexity of its valves in the umbonal region, the much more prominent and strongry incurved beak of the ventral valve, the absence of a foramen, the much greater width and shallowness of the sinus and fold, and the stronger and more crowded lines of growth. I have not seen any example which exhibits the interior.

Lneulity and Fonmution. - Shales of the Hamilton Group, Widder, Township of Bosanquet (Collected by Mr. George Jennings Hinde).

\section{Genus Amphigenia (Hall).}

". Shell inequivalve, oval, ovoid, or sub-triançular, more or less convex or gibbous, without mesial fold or sinus. Valves articulating by teeth and sockets, without area. The dental lamella in the ventral valve conjoined on their dorsal sides, forming an angular trough or pit, which opens exteriorly by a triangular fissure beneath the beak, and in its anterior extension is supported on a central septum. Dorsal valve with a strong thickened cardinal process or hinge-plate, bordered by the teeth sockets, anchylosed to the bottom of the ralve and supporting the crura, which extend into the carity of the shell" (Mall, Pal. X. Y. Vol. IV., p. $382)$.

In addition to these characters, there is a foramen which exteuds beneath the hinge1 late of the dorsal valve, and euds in a perforation at the beak, and the shell-structure is distinctly punctate.

Hall has separated the genus Ampleigrniu from Strirliturlinie (Billings) to include the

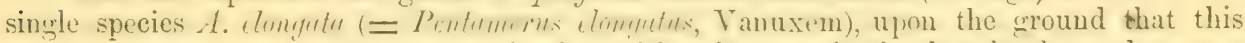
species possesses no area in the ventral valve, with a foramen in the dorsal valve and a punetate shell structure. On the other hand the typical species of strirlinmliniu possess an area in the veutral valve, a smaller ancular pit, no foramen in the dnrsial valve, and an impunctate and fibrous shell-structure. Without entering further into the enntroversy which has been carried on as regards this question, it may he said that these differences appear sufficient to entitle Amphigenic to be considered as distinct, if not generically, at any rate sub-generically from Stricklandinia and Pentamerus.

From linsslurit, in spite of great resemblance in external form, and also as regards some points of internal structure, the cenus. Amphimenie is seprarted l,y the angular pit made by the conjoined dental lamellee of the ventral valse. and by apparently having free crura in the dorsal valve without appendages.

The only species of this genus known in Canada, is thic Amphigrmin clonufute of the Corniferous limestone.

\section{Amphigenia elongata (Vanuxem).}

Pentamerus elongatus (Vanuxem), Report Third Geol. Dist. New York, p. 132.

Meganteris elongatus (Hall), Tenth Report on the State ('abinet, p. 123.

Fiensselceria elongata (Hall), Pal. N. York, Vol. III, p. 453.

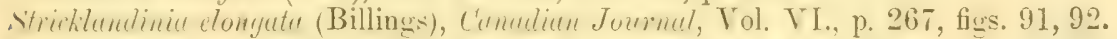
Amphigenia elongata (Hall), Pal. N. Y., Vol. IV., p. 383, Pl. LIX.

Shell very rariable in form, generally elongate oral, sometimes ovate, the length sometimes nearly twice the width, or the tro dimmeters at other times nearly equal. Sides gently curred, or nearly straight ; frent pointed, rounded, or sub-truncate; rentral ralve courex. in general more so than the dorsal valve, often obtusely carinated centrally in its upper half; the beak incurred orer the umbo of the dorsal valve. Dorsal valve less ennrex as a rule than the ventral, often elevated along the middle line in its upper half, and de. pressed towards the sides and front. Surface usually smooth, but marked with strong concentric ridges and lines of growth. In perfect specimens, the surface is stated to exhibit regular radiating flattened stria. Leugth of a small individual eighteen lines, greatest width ten lines. Larger individuals range from two to as much as four iuches in length. 


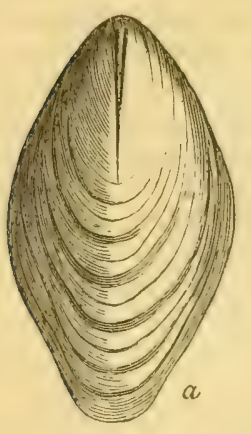

Fig. 29.

Amphigenia elongata (Billings). a. Exterior of the ventral valve of a small example; $b$. Interior of the 1 mbonal region of a broken ventral valve showing the trough
between the dental lamellix. Both of the natural size. Cormiferous Limestone. rather shorter, with a thickened hinge-margin, and a rised

Only two species of this genus have come under my notice as occurring in the Devonian Rocks of Western Ontario, and in neither case, though in one instance the specimens are well preserved, have I been able to determine the species with certainty. Sooner, however, than add any fresh species to this already over-crowded genus, I have referred our forms provisionally to the following previously recorded species.

\section{Lingula SQUAMIformis (Phillips)?}

Lingula squamiformis (Phillips), Geol. of Yorkshire, Vol. II., Pl. IX., fig. 14.

Lingulu squemiformis (Davidson), Monograph of British Carboniferous Brachiopoda, p. 205 , Pl. XLIX., figs. 1-10, and Monograph of British Devonian Brachiopoda, p. 105, Pl. $\mathrm{XX}$., figs. 11, 12.

Lingula mola (Salter), Quart. Journ. Geol. Soc., Vol. XIX., p. 480.

"Shell longitudinally oblong, one-third or less longer than wide, with sub-parallel sides, the broadest torvards the anterior extremity, the frontal margin assuming either a very slight inward or outward curve. The anterior portion is gradually curved on eitner side, the beak being rounded or but slightly angular at its extremity in the dorsal valve, with a thickened margin, tapering, pointed retrally at its termination in the ventral one, which is consequently so much longer than the opposite valve. The ralves are slightly convex, but somerhat depressed along their middle. In the dorsal one there exists a small apex close to the rounded margin of the beak, and from which usually radiate three small rounded ridges, separated by shallow sulci. The external surface in both valves is covered with numerous fine concentric strix, or lines of growth, giving to the shell a beautifully and delicately sculptured appearance, for the minute plications of growth succeed each other with much regularity, while some stronger lines or interruptions of growth are produced at variable distances" (Davidson).

Large individuals have a length of nineteen lines and a width of thirteen lines; smaller have a length of nine lines and a width of six and a half lines.

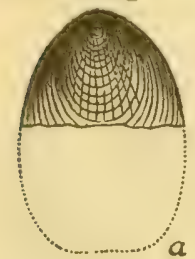

Fig. 30

I have several fragments of a large, oblong, flattened Lingula which appears to be more closely allied to $L$. squamiformis, (Phill.) from the Carboniferous and Devonian Rocks of Britain, than to any other species with which I am acquainted, though I am not at all certain that it can be regarded as specifically identical with this species. In the imperfect condition of our specimens, however, it is best to place them here provisionally. The chief point in a. Fragment of Lingula squamiformis (Phillips)? ${ }^{2}$ Which our examples differ from L. squamiformis is natural size, from the Corniferous limestrne. b. Lim-
gnila maide (Hall), natural size, from the Corniferous that the beak appears to be more broadly rounded,
Limestone. and the sides are not quite so straight. Some of 
Mr. Davidson's figures (Loc. cit) would, howerer, agree well enough in these respects with our form, though this does not seem to be the normal condition of the species. The front portion of the shell is not exhibited by any of the specimens that I have seen, and it is, therefore, impossible to decide as to whether it was truncated or not. The only species of Lingulı which has been described by Hall from the Devonian strata of New Jork, and which has any affinity with the present form, is L. Munni (Pal. N. I., Tol. IV., p. 6, Pl. II., fig. 3). If this be specifically distinct from $L$. stucumifurmis, it is possible that our specimens may belong to it, but I prefer keeping them distinct at present, as they are consideritbly larger and broader.

Locality and Formation.-Rare in the Corniferous Limestone of Port Colborne.

\section{LingULA MAIDA (Hall)?}

"Shell linguiform, elliptical, greatest width a little more than half the length, uarrowing gently towards cither extremity, obtusely rounded and yroduced below, and more acutely converging tuwards the beaks. Surfice very gently conves betow, and a little more convex on the umbo, marked by fine thread-like stria, which are sometimes crowded in fascicles" (Hall. Pal. N. Y., Vol. IV., p. 9, Pl. II., fig. 13).

I have only a single specimen, but that a remarkably well-preserved one, of this form. which I identify with some doubt with L. maind (Hall), from the Inamilton group. Our specimen is from the Corniferous Limestone, and arrees in all essential characters with the abore quoted description, though slightly smaller than the specimen figured by Hall. It is apparently a rentral ralve, its lenerth being eight lines, and its sreatest width about four lines and a-half. The surface exhibits no radiating stria?, but is covered with elevated. thread-like, concentric lines of growth, about from twelre to fourteen of which occupy the space of one line.

Loculity and Formution.-Corniferous Limestone, Inagersville, Tommip of Oneida.

\section{Genus Pholidops (Hall).}

The shells of this genus are small, and rery similar in appearance to the dorsal valres of small specimens of Jistinu. The valves are squamiform or discoid, calcarcous, and app:rently destitute of a formen in either valve. They differ from tha genus r romin in the fiuct that the shell is apparently free and unattached to other hodies. The interior shows a stron!muscular callosity. Except in the characters of the interior. Pholithos appears to agree altogether with McCoy's genus l'sendurtuin, with which, perhaps, further observation wili unite it. I have found a single species of the genus in the Corniferous Limestone.

\section{Pholidops ovatus (Hall).}

Pholidops ovatus (Hall) Pal. N. Y., Vol. III. p. 490, Pl. CIII. B., Fig. 7.

Shell minute, ovate, slightly longer than wide. in shape l)iscinoid, with a minute excentric apex. Surface marked with fine concentric stria of growth, about twelve of which occupy the space of one line.

I have only a single example of this form, but I have no doubt as to its identity with Hall's species.

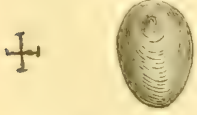

Fig. 31. enlarged. From the Corniferous Limestone
1holitopescerutus(Hall)

It appears, also, very doubtful if the $P$. Hamiltonice of Hall, from the Hamilton group can be specifically separated from $P$. ovatus. Our specimen has a length of a line and three quarters by a width of a line and a half.

\section{Loculity and Furmution. -Corniferous Limestone, Port Colborne.}

\section{Genus Cerlospira (Hali).}

Shell "concavo-convex, having the ventral valve convex, or sometimes sub-angularly arching over the concave dorsal valve. The surface of the shell is striated or plicated, witi the plications simple or bifurcating, and of which two or more in the centre of the rentrat 
valve are more conspicuous than the others, forming a more or less defined mesial fold; upon the dorsal valve there is a corresponding depression. The space between the valves leaves little room for the spires, and these appendages appear to be somewhat loosely arranged, with their apices approaching each other. These shells are apparently fibrous in texture, and on this account, and from the position of the spires, they approach more nearly to Atrypa than to Trematospira, to the latter of which they are more nearly allied in external form " (Ilall, Pal. N. Y., Vol. IV., p. 328).

Only one species of this genus, viz., C. concciva (Hall), has as yet been recognized as occurring in the Devonian rocks of Western Canada.

\section{Ceelospira concava (Hall).}

Leptocolia concure (Hall), Pal. N. Y., Vol. III., p. 245, Pl. XXXVIII., Figs. 1-i.

Leptocelia concava (Billings), Canadian Journal, New Series, Vol. VI., p. 352, Fig. 127. Colospira concave (Hall), Sixteenth Report on the State Cabinet, p. 60.

Calospira concava (Hall), Pal. N. Y., Vol. IV., Pl. LIII., Figs. 13-19.

Shell small, ovate, or sub-orbicular, the width being equal to or a little less than the length. Ventral valve convex, elevated along the middle, the beak small and incurved. Dorsal valve flattened laterally, and depressed in the centre, forming a shallow and obscure mesial series. Surface with from ten to fourteen or more rounded radiating ribs, which occasionally bifurcate.

According to Hall, the dorsai valve has a small false area, and a triangular foramen which is sometimes closed below by a deltidium.

Average individuals of this species have a length of about three lines, and a width of the same or a little less. Detached valves are not uncommon in the Corniferous Limestone, but I have not seen a single perfect specimen.

In general form, and in its surface-characters, Celospira concara (Hall) closely resembles Leptocklic fabellites (Conrad), and the two species have been usually regarded as belonging to the same genus. According to Hall, however, C. concuva possesses internal spires, which are wanting in $L$. flabellites, thus necessitating the creation of a new grenus for the former and for some allied species.

Locality and Formation.-Corniferous Limestone, Port Colborne and Hagersville.

\section{Gemus Centronelua (Billings).}

"Shells having the general form of Tcreliatula. Dorsal ralve with a loop consisting of two riband-like lamella, which extend about one-half the length of the shell. These lamellae at first curve gently outwards, and then approach each other gradually, until at their lower extremities they meet at an acute angle; then becoming united they are reflected backwards towards the beak, in what appears to be a thin, flit, vertical plate. Near their origin each bears upon the ventral side a single triangulitr crural process. This genus appears to stand between Terctrutulu and IF aldheimiu. In the former the loop is short, not exceeding greatly one-third the length of the shell, and not reflected. In the litter it extends nearly to the front, and is reflected, but the lamina are not united until they are folded back" (Billings, Canatian Journal, New Series, Vol, VI., p. 271, and Cunadiun Nuturalist, Vol.IV., p. 1:31).

Two species of this genus at least occur in the Corniferous Limestone; but good specimens are rarely to be procured, and I possess nothing more than detached valves, in which none of the internal characters are exhibited.

\section{Centronella glans-Fagea (Hall).}

Rhynchonellu glans-fuged (Hall), Tenth Report on the State Cabinet, p. 125.

Centronella gluns-fageu (Billings), Canadiun Journal, New Series, Vol. VI., Figs. 97, p. 271.

Centronelle glens-fager (Hall), Sixteenth Report on the State Cabinet, p. 45, and Pel. New York, Vol IV., Plate LXI., A. Figs. 1-21, 25, 26.

Shell small, ovate or sub-rhomboidal, the greatest.width about the middle, from which point the sides slope to the beaks at an angle of about $85^{\circ}$; front rounded; valves very un equal. Ventral valve considerably larger than the dorsal, convex, sub-carinate along th 
middle, abruptly curved towards the sides, and regularly arched from the beaks to the front. Beak extended beyond that of the dorsal valve and much incurved. Dorsal valve nearly flat or slightly convex above, with a wide undefined sinus, which often extends in front across the entire width of the shell. Surface smooth, or with obscure concentric lines of growth; shellstructure finely punctate. less.

Length from two to four or five lines, the width being equal to the length or a little

Detached valves of $C$. glens-fugen are of not uncommon occurrence in the Corniferous Limestone. Occasionally individual examples are found having a length of from six to eight lines, and these Mr. Billings thinks may perhaps be distinct. I am inclined to think, however, that they are only large and tumid specimens of $C$. glans-fagea.

Locality and Formation.-Corniferous Limestone of Port Colborne.

\section{Centronella Hęcate (Billings).}

Centronelle Hecute (Billings), Cunutiun Jummal, New Series, Vol. VI., p. 272, Fig. 99.

Shell small, "elongate, oval, or sub-rhomboidal ; apical angle from 45 , to 60 " sides somewhat straight from the beak to about the middle, where, making a rounded angle, they converge towards the front margin, which is somewhat truncate for about one-third the width. Tentral valve strongly but broadly carinate from the beak along the middle to the front, descending with a flat or gently convex slope to the sides; in outline only, gently arched longitudinally ; in some specimens nearly straight; the beak small, elongated, ereet, aud with a triangular foramen. Dorsal valve gently couvex in the upper half, and with a wide shallow sinus in the lower half. Surface smooth. Length from two to four lines; width ab sut three-fourths the length" (Billings).

Our collections comprise a few specimens which appear to agree in their essential characters with the above descriptions; but the materials at present in my hands are simply sufficient for identification.

Locality and Formation.-Corniferous Limestone, Port Colborne.

\section{CHAPTER IV.}

\section{POLYZOA OE THE CORNIFEROUS AND HAMILTON FORMATIONS.}

The remains of Polyzo in the Deronian Rocks of Western Ontario are very abundant, and they are of unusual interest in many ways. Tufortunately; howerer, they are. for the most part, more or less fragmentary, and their sturly is thus attended with special difficulty, since there is no class of organisms requiring greater sill and patience in their interpretation. Altogether, I have been able to identify nimeteen species of I'wly:m, of which no. less than fifteen appear to be new, whilst several form have come to light belonging apparently to new generic types. There remains, howerer, a considerable number ot forms, of which the materials at present in my hands are too fragmentary to justify me in describing them definitely. The forms which I have considered myself warranted in describing. helong to the following

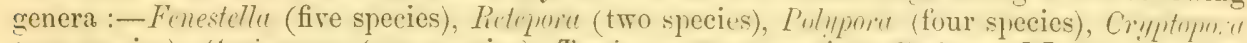

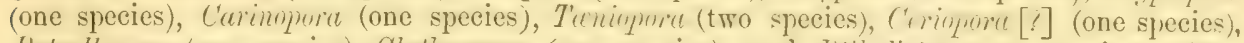
Botryllopora (one species), Clathrupora (one species), and I'tilutictyu (one species). Thie

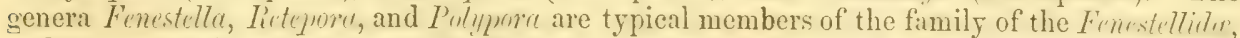
and they comprise more than half of the total number of species identified. It is to these three genera, also, that most of the undeterminable fratgments belong; so that the Fenestrlirler must be considered as haring had a very great derelopment in the Devonian period in North America. The genera Cryptopnia and Curinopor, now characterised for the first time, also belong to the Fenestellider, though they exhibit many extraordinary, and indeed, altogether unprecedented, points of structure. The new genus botiy?lingru can hardly be compared with any known group of the Palæozoic Pulyzor, hut the well-known Silurian genus Ptilmlictya is represented by at least one form; and Cerioporc (?) Humiltonensis is related to certain well-known types in both the Silurian and the Carboniferous Rocks. 


\section{Genus Botryllopora (Nicholson).}

\section{(Canadian Journal, Vol. XIV., No. 2, 1874.)}

Polyzoary calcareous, sessile and encrusting, forming systems of small circular dises, the upper surfaces of which are marked with radiating ridges upon which the cells are carried. Each dise is attached by its entire lower surface, slightly convex above, with a central nonporiferous space, round which a number of radiating poriferous ridges occupy an exterior slightly elevated zone. Cells forming a double series on each ridge, immersed, with rounded mouths which are not elevated in any part of their circumference above the general surface.

I have been unable to refer these singular Polyvo to any existing group, and have, therefore, been compelled to form a new genus for their reception. In some respects the genus is allied to Defrancia, but the cells are not tubular, and no portion of them is free, whilst the latter genus does not appear to have ever been detected in rocks older than the Jurassic. The only Palaozoic genus of Polyzoa which, so far as I am aware, presents even a superficial resemblance to Botryllopora, is Enctetinopora of Meek and Worthen. In this latter zenus the polyzoc ry is star-shaped, but its internal structure is quite peculiar and altogether different to that of Botrylloporc, whilst the entire organism appears to have been free.

The individual dises of Botryllopore present, however, a very striking resemblance to the separate star-shaped elevations of Stellipora antheloidece (Hall), from the Lower Silurian; and it may, therefore, be proper to say a fer words on the structure and affinities of this grenus, of which I have examined authentic specimens. Stellipora antheloirlea occurs in the form of flattened expansions or of erect, flattened and sub-palmate fronds. The surface exhibits a vast number of little star-shaped elevations, each about a line in diameter, and consisting of a smooth, sometimes slightly depressed space, which is traversed by five, six or more obtuselyrounded radiating ridges, which do not quite meet in the centre. Each of the ridges of the star is covered with a number of rouniled calices, irregularly disposed in two, three or four rows. The stars are arranged irregularly, gencrally at intervals of from half a line to a line, and the interspaces between them are occupied by crowded circular pores, which are the mouths of so many conenchymal tubuli. These pores do not encroach upon the spaces between the ridges of the stars, and the tubuli of which they are the mouths are seen on traverse section to be tabulate. being furnished with distinct transverse partitions. It thus appears that Stelliporca antheloite! (Hall), is not a Polyzoin, as believed by D'Orbigny, but a tubulate corul, allied to Monticulipriv, and presenting in particular a specially close resemblance to the coral which I have deseribed under the name of Callopora incrassata.

\section{Botryllopora socialis (Nicholson).}

Botryllopora socialis (Nicholson), Geological Magazine, April, 1874.

Polyzoary social, consisting of systems of calcareous discoid bodies, which are closely adherent by their lower surface to the exterior of foreign objects. The upper surface of each dise is on the whole convex, but with a central cup-shaped depression or flattened space, the exterior portion of each being vecupied by a series of strong elevated ridges or ribs arranged in a radiating manner. The diameter of the dises is about a line or a line and a quarter, and the radiating ridges are from eighteen to twenty-six or more in number. The radiating ribs are also unequally developed, some extending much nearer to the centre than the others, and each carries upon its upper surface a double row of minute round pores or apertures, the margin: of which are not elevated above the general surface. The central space of the polyzoary is destitute of cells, and apyears to be solid, and this seems also to be generally the case with the

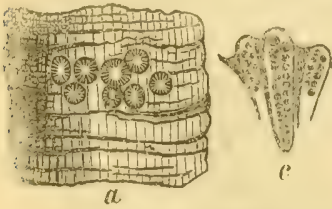

Fig. 32.

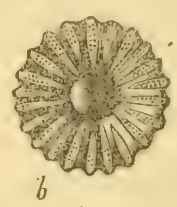

spaces between the radiating ribs. In some cases, however, the interradial spaces appear to be poriferous in the immediate vicinity of the circumference.

The groups of this singular Polyzoön are not of very rare occurrence in the Hamilton formation, growing parasitically upon the exterior of Heliophyllum Halli. It has at first sight, a close resemblance

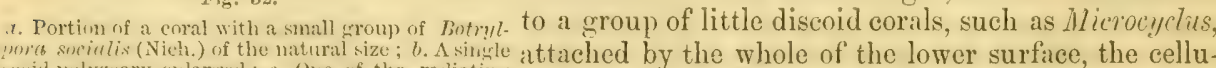

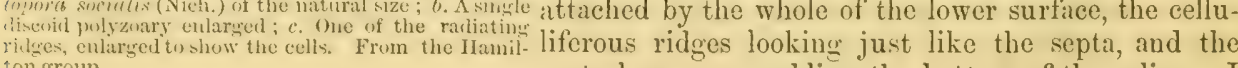
ton group. 
do not know of any Palæozoic forms of Polysoce with which this could be compared, and it is readily separated from such forms as Difrencia by the entirely different characters of the cells, which approach closely in form to those of lieteporu, Pulyporia, and Fenestella. The largest group that I have seen comprises about twenty of the discoid concecia, mostly in contact but apparently in no way connected with one another directly.

Lorrelity anu. Formation.-Hamilton Group, Bartlett's Mills, near Arkona, Bosanquet.

\section{Ceriopora (?) Hamiltonensis (Nicholson).}

Ceriopora (?) Hamiltonensis (Nicholson), Geological Magazine, April, 1874.

Polyzoary ramose; branches cylindrical, about half a line in diameter, dividing dichotomously at intervals of from a line and a half to three lines, the angle included between each pair of brauches heing about $41^{\prime}$ or $45^{\circ}$. 'Surface covered with oval, rounded, or subquadrate cell-mouths, arranged in longitudinal rows, which are separated by delicate threadlike lines. The cells of each row alternate with those of the next row, so that they come to be disposed in recular diagonal lines. About four rows (sometimes five) oceupy the width of the stems, the cells having a width of about a tenth of a line; and there are about five cells in the space of one line, measured vertically. The interspaces between the mouths of the cells are occupied by exceedingly minute tubuli, which form only a single row or are altogether absent on the lines which bound the cells laterally, whilst they usually form a double series on the spaces by which the cells of a given row are separated vertically.

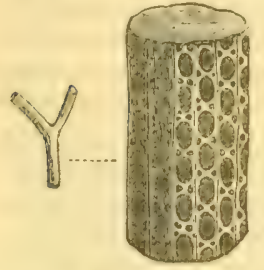

Fig. 33.

firtion of the stem if Ciriogrera (!) Hamiltunensis (Nich.) natural size, showing the mode of iranchine. "s a frawment of the same enlarced to show. the form of the cells and the tubular intercellular interspaces.From the Hamilton group

This beautiful little fossil occurs in great abundance in some of the beds of the Hamilton Formation. It is allied to the Ceriopora punctata of Goldfuss (Petref. Germ. Pl.LXIV., Fig. 12,) and to Millepora interporose, (Phillips, Geol. of Yorlishire, Vol. II., Plate I., Figs. 36-39), especially to the former, but it is distinguished from both by perfectly good and easily recognized characters. I am, at present, unable to decide as to its true generic affinities, and hare simply referred it provisionally to ciriu.

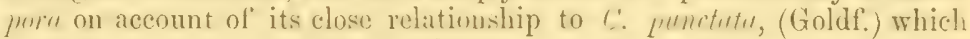
likervise occurs in the Devonian Rocks.

Lumbitu and Furmution. Common in the TTamilton Formation. Widder, Township of Bosanquet.

\section{Genus Ptrlodictra (Lonsdale).}

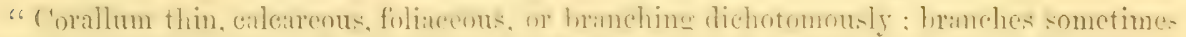

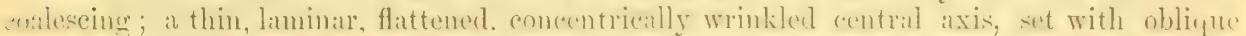

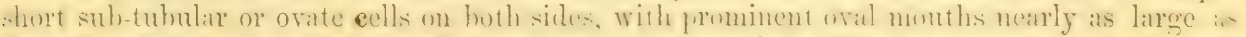

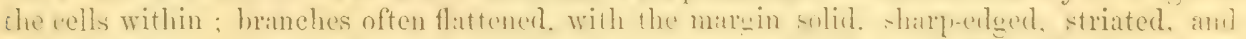
without ce!ls; the boundary ridges of the cel!s square or rhomboidal " (NicCoy).

The genus Ptilodictyce of Lonsdale is identical with Stictopora of Hall, and includes a fromp of eurions J'uly:ur, which are eswentially silu bim, but which estend into the Devonian Rocks, and aplear even to hase survived inte the ('arboniferous perimb. The presence of a sun-celludiferous striated margin does not appen to be ab-olutely esential or to be universaliy mesent in the enus; and the ecntral laminar axis or septum. Which separates the eells of iplw-ite sides, is sometimes longitudinally striated, as well as being conecntrically wrinkleri. I ingle species of the genus, which I commot identify with any previously recorded species. necurs plentifully in the Corniferous Limestone, and more rarely in the IIamilton formation of Western Ontario.

\section{Ptilodictya Mieeki (Nicholson).}

Ptilodictya Meeki (Nicholson), Geological Magazine, March, 1874.

Polyzoary having the form of thin, very much flattened elliftical branches, which hare an arerace width of about a liue, rarely reaching a line and a half or two lines, with a thich- 
ness of about half a line ; dividing dichotomously at angles of $50^{\circ}$ or $60^{\circ}$, generally at intervals of from four to six lines. No developed non-poriferous margins, the whole exterior surface seeming to be occupied by the cells. Cells tubular, curved, opening by oval mouths, arranged in rows which are separated by delicate thread-like lines. About ten rows of cells in the space of one line, the cells of each row alternating with the next, so that the cell-mouths have a quincuncial arrangement. About five cell-mouths in the space of one line, measured longitudinally, the interspaces between them being generally considerably longer than the long diameter of the cell-mouths themselves. The partition or laminar axis between the cells on the two sides of the polyzoary is marked with delicate longitudinal strix, which correspond with the rows of cells, together with obscure concentric wrinkles, the convexity of which is directed towards the apex of the frond.

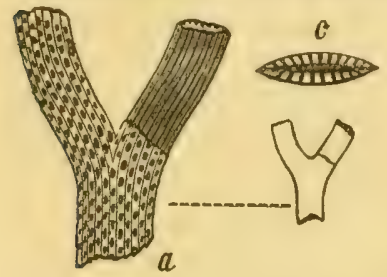

Fra. 34.

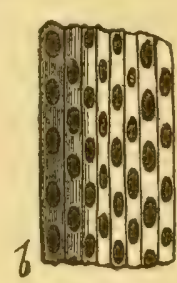

6

This species presents a close resemblanee to Ptilodictya Gilberti, (Meek), from the Corniferous Limestone of Ohio (Geol. Survey of Ohio, Palæontology, Vol. I., Plate 'XVIII., Fig. 1,) with which I was at first disposed to identify it. I have, however, been compelled to separate it as a distinct species upon the following grounds:1. P. Gilberit is stated to have eight or ten rows of cells in the space of two and a half lines; whereas $P$. Meeki has never less than ten in the space of one line, which would give twenty-five

Ptilodictya Mecki (Nicholson); a, Portion of the poly zoary magnified to show the branching, and the lonoitudinally striatedaxis; $b$, A fragment enlarged, showing the magnified. From the Corniferous Limestone.

rows in two and a half lines. 2. The central laminar axis of $P$. Gilberti is said to be covered with regular, arched transverse striæ; whereas that of $P$. Mecki exhibits well defined longitudinal striæ, with either no transverse striæ, or with but obscure transverse wrinkles. 3. P. Gilberti, in common with the typical species of the genus, possesses well-marked striated and non-poriferous margins; but I have been unable to detect any traces of these in the numerous specimens of $P$. Meeki, which have passed under my notice. 4. P. Gilberti seems to be upon the whole a larger and more robust species, sometimes attaining a width of three lines, whereas the average width of $P$. Meeki is only about one line or a little over. I have, therefore, thought it safest to separate $I$. Meeli under a distinct specific title, and I have named it in honour of Mr. F. B. Meek, one of the most distinguished palæontologists of America.

In some respects $P$. Mecki presents considerable resemblance to $P$. fenestrata (Hall), from the Cbazy Limestone; but in the absence of any sufficiently detailed description of the latter species, and especially of accurate measurements, it is impossible to say how close this resemblance may really be.

So far as at present known, $P$. Gilberti (Meek), and the present species are the only forms of the genus Ptilodictya, which have hitherto been detected in the Devonian Formation.

Loculity and Formation. - Common in the Corniferous Limestone of Port Colborne. Rare in the Hamilton formation of Bartlett's Mills, near Arkona, Township of Bosanquet.

\section{Genus Polypora (McCoy).}

"Corallum forming a delicate, reticulated, calcareous expansion, usually fan-shaped; interstices" (branches) "round, having on one side from three to five rows of cell-openings, the margins usually not projecting ; interstices connected by thin, transverse, non-poriferous dissepiments ; reverse rounded, striated, or granulated" (McCoy, Pal. Foss. p. 115).

According to the above definition, Polypore is distinguished from Retepora by the possession of distinct dissepiments, which do not bear pores; whereas in the latter genus the branches inosculate directly, without the development of distinct dissepiments, and the points of junction of the branches carry cells. There are, however, certain forms, such as $P$. (Gorgonia) ripisteria (Goldf.) and P. gracilis (Prout.), in which the froud resembles Fenestella and the typical forms of Polypora, in having the branches united by distinct dissepiments, but these dissepiments carry pores, whilst there are three or more rows of cells on the branches. It is, therefore, necessary either to constitute a new genus for the reception of these forms, or to admit that the dissepiments of Polypora may carry pores. If the latter course be adopted, Polypora will agree with Fenestella in the general structure of the polyzoary, but will be distinguished by the greater number of the rows of pores to each branch, and by the absence of 
distinct carinæ. From Retepora, again, Polypora will be distinguished solely by the fact that the branches in the latter genus are united by distinct poriferous or non-poriferous dissepiments, whilst in the former the branches simply anastomose or inosculate.

McCoy states that no infundibuliform species of Polypora had come under his notice; but I have seen such, and in these cases the cells are born by the inner faces of the branches.

The following species of Polypora have come under my notice in the Corniferous Limestone of Western Ontario:-

\section{Polypora pulchella (Nicholson).}

\section{Poiypora pulchella (Nicholson), Geological Magazine, April, 1874.}

Polyzoary infundibuliform or flabellate, often attaining a considerable size. Branches nearly straight, radiating from the base, and increasing in number by bifurcation at intervals of from two to four lines. About six branches in the space of a quarter of an inch, the diameter of the branches being about one-forty-fifth inch, the interspaces slightly narrower. Dis-. sepiments on the same plane as the outer surface of the polyzoary, depressed below the inner surface, short, narrower than the branches, and placed at intervals of about half a line apart. Fenestrules regularly oval, half a line in length, and about a quarter of a line broad, four or five in the space of a quarter of an inch, alternate or sub-alternate in contiguous rows. The upper or inner surface of the branches carries the pores or cells, three rows of which occur on every branch, and sometimes four opposite the origin of the dissepiments. The cells are flask shaped, sometimes slightly unequal in size; their mouths round; those of the central row alternating with the lateral rows. From six to cight pores in the space of a line, or three to four in the length of each fenestrule. The reverse fuce of the polyzoary is smooth or obscurely striated.
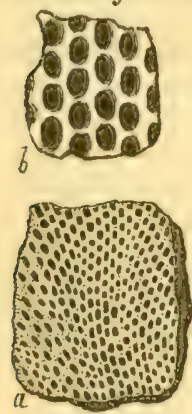
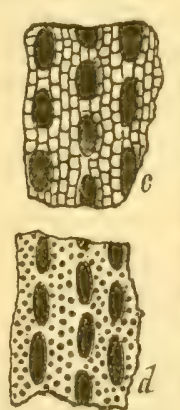

Fig. 35. $-\alpha$. Fragment of Polypora pulchella (Nich.), natural size; b. portion of the reverse of the same magnified; $c$. fragment from which the exterior non-poriferous face has been stripped away, enlarged to show the cells; $d$. cast of the inner snrface, enlarged, showing the cell-mouths, From the Corniferous Limestone.

\section{Polypora Halliana (Prout).}

Polypora Halliana (Prout), Proc. St. Louis Acad. Sci., Vol. I., p. 580.

Polypora Halliana (Prout), Geology of Illinois, Vol. II., plate XXI, Fios. 4-4b.

Polyzoary essentially sinilar in its characters to the preceding, but differing in its dimensions and the number of the rows of cells. Cœnœcium forming broad flattened expansions, the branches of which radiate from the base, increasing by bifurcation at intervals of from three lines to half an inch. The branches are round, nearly half a line in width, about four or five in the space of a quarter of an inch. l)issepiments small, depressed, not more than a fiftieth of an inch in width, often appearing to be little more than connecting points between the branches. Fenestrules long-oval, one line or nearly in length, and about half a line or less in width; about three in a quarter of an inch measured longitudinally, and the same number in the space of two lines measured transversely. No pores upon the dissepiments. Cells arranged. in four alternating rows upon the branches, their apertures rounded; about four to the length 
of a fenestrule, separated by obseure and delicate undulating striæ. Reverse apparently smooth.

I have little doubt as to the identity of our specimens with those deseribed by Prout, though there are some trivial differences. From P. pulchella (Nich.) the present species is readily distinguished by the more robust branches, the greater length of the fenestrules and their smaller width, as well as by the jossession of four, instead of three, rows of cells. fleet.

Lonality und Formation.- - Rare in the Corniferous Limestone of Lot 6, Con. 1, Wain-

\section{Polypora tenelia (Nicholson).}

Polypora tenella (Nichulson), Geological Magazine, April, 1874.

Polyzoary small, forming a flattened expansion; branches radiating from the base, and increasing by bifurcation at intervals of about two lines. Branches uarrow, about eight in the space of a quarter of an inch, their width being about a quarter of a line. Fenestrules oval, about cight or nine in a quarter of an inch, measured longitudiually, and ten in the same space neasured transversely ; the length of each about half a line, the width a third less. Dissepiments very short and narrow, without pores. Cells arranged in three alternating rows on the branches, opening by minute rounded apertures, two or three of which occupy the space of a fenestrule. Reverse unknown.
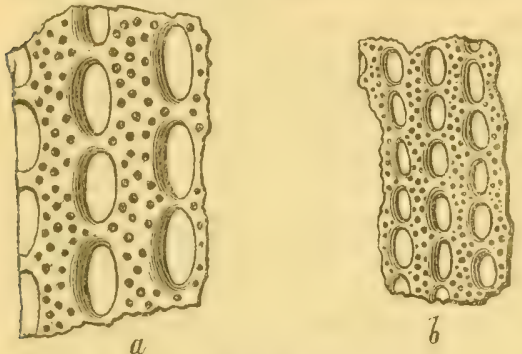

This pretty little species is distinguished from the preceding forms by its much more delicate proportions, its narrower and more closely set branches, and its much smaller fenestrules.

Locality and Formation.-Rare in the Corniferous Limestone of Lot 6, Con. 1, Wainfleet.

Fig. 36 .

a. Fragment of the cast of Polypora Halliana, (Prout), magnified ; $b$, fragment of the cast of Polypora tenella (Nich.), enlarged. From the Corniferous Limestone.

\section{Polypora tuberculata (Nicholson).}

Polypma tuberculata (Nicholson), Geological Magazine, April, 1874.

Polyzoary small, forming a flattened expansion which springs from a strong foot-stalk. Tranches radiating from the base, and ivcreasing by bifurcation at intervals of about a line and a balf, from a third to half a line in breadth, rounded, and destitute of carina. Dissepiments rery short, widest at their junction with the branches. Fenestrules somewhat irregular in shape, usually a very long oval, always longer by from one half to two-thirds than wide: having an average width of a third of a line to half a line by a leugth of one line or a little les.: Two fonestrules in two lines measured longitudinally, and four in the same space measured trausversely, those of contiguous rows being usually opposite or nearly opposite. Disse. pimentsnon-poriferous. Four (sometimes three) alternating row's of cells on each brauch, opening by minute rounded pores, which are prominently clevated above the general surfice. Five pores to the length of a fenestrule. Reverse unknown.

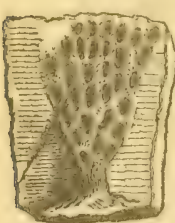

a

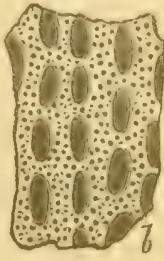

Fig. 37 .

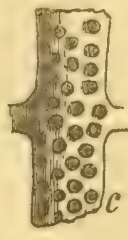

Polypora tuberculata differs from all other recorded species of the genus, except P.vervi$\operatorname{cosa}$ (McCoy), by the possession of prominentedged pores, which give to the celluliferous surface of the branches a peculiar tuberculated appearance. The latter, however, has exceedingly long and narrow fenestrules, with nearly twice as many pores to the length of a fenestrule. I have only seen fragmentary examples

a. Fragment of Polypora tuberculata (Nich.), natural size; of the species.

$\therefore$ The same cularged ; c. Portion of a branch, still further

cinlarged. From the Hamilton group. 


\section{Loculity und Formution.-Rare in the Hamilton group, Bartlett's Mills, Arkona, Township of Bosanquet.}

\section{Genus Retepora (Lamarck).}

Polyzoary forming a reticulated expansion composed of flexuou; inoseulating branches, which are not united by distinct dissepiments, but which anastomose in such a manner that the entire frond forms a continuous network perforated by recular apertures or fenestrules. In the funnel-shaped species the cells are placed on the upper or inner surface of the ecentecium, and there are two or more row: of cells to each branch. Outer surfuce striated.

The genus Retrymin is separated from Pulmprit! by the fact that the fenestrules are formed simply by the coalesceuce of the flexuous branches at definite points, and thus look like perforations in the connecium, whereas in the latter the fenestrules are formed by a distinct series of non-poriferous dissepiments. From Fenextell', Reteporu is separated by not possessiug dissepiments and by the common occurrence of more than two rows of cells to each branch, In the funnel-shaped species of litrime the cells certainly u-ually occupy the internal face of the funuel, whereas they are generally exterual in those species of Fenctullu which have the sime shape. I should be inclined to doubt, however, if thi- character is universal, and it certainly canuot often be used as a practical means of distinguishing the species of these two gencril, since its applicution fails in the case of fragments of the infundibuliform species, and also of the fan-shaped forms.

The following species of list purn occur in the Devonian Rocks of Western Ontario.

\section{ReteporA PRISCA (Goldfuss).}

Reteporc prisca (Goldfuss), P'etref. Germ. Pl. XXXVI., fig. 19.

Retepore prisca (Phillips), Pal, Foss. Cornwall, \&c., p. 25, fig. 37.

Fenestella prisca (NcCoy), Pal. Foss., p. 76.

Polyzoary forming broal, far-shaped. or undulating expansios. which in some iustancehave the firm of an open funnel. Branches parallel, flexuons, and undulating, alternately and regularly bent from side to ride, the snecensive ennexities and concavities on each side of each branch being opposed to correpunding consexities and concavities in the branches immediately contiguous, actual anastomosi taking place at the sucessire points where two convexities meet, so that the entire fimm becomes perforated by a serites of oval apertures or "fenestrules." Branches ah ut me-third of' a line in width, cight or nine in a quarter of an inch neasurel transversely, furni-hed with astrom but blunt keel on the non-eelluliferous side, so that their backs are anculated. Leverse. when well-preserved, finely striated. Fienestrules regularly alternate in antipuns roms, and thus arranged in diagual lines. broadoral or diamond-shaped, half a line in length and rather less in width. three in the space of

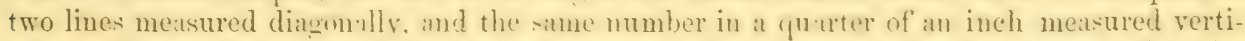
cally. Fenestrules separated rertically by interspaces of about half a line, along which the branches are conlescent. ('alls carried in the fum. l-hatped examples on the inner or upper surface of the en,noecium : two rows of colis to each hranch, alternately arranged, and those opposite the points where the brandics unite litrer than the others. Four or five cells to the length of a fenestrule.

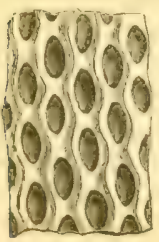

$a$

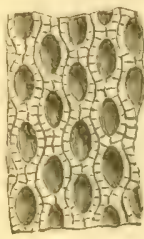

6

Fig. 38.

I have no doubt as to the identity of this abundant species with the familiar Retepora prisca of the Continent of Europe and Great Britain. The only point in which our species appe:Ir: to differ from li. prisen is in the angulation (for it is this, rather than a true carination) of the non-cellular face of the branches. This feature, howerer, is only shown in very well preserved specimens, and is absent in others, and I do not think it is one of such importance as to justify the formation of a new species. I do not comprehend upon what grouvds McCoy sh. uld have placed this species under Fonestrlla, since its reference tri Pitrpora is rendered indubitable by the marked absence of distinct dissepiments, and by the fact that the fenestrules are formed

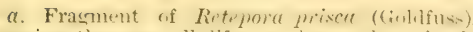
showing the inen-celluliferous iace, enlarued. Frament wi the same from which the striated outer layer has been removed, showing the backs of the cells, enlarged. From the Corniferuus Lintstone. ments, and by the fact that the fenestro

simply by the coalescence of the flexuous and regularly undulated branches.

Loculity und Fommetion. - Common in the Corniferous Limestone of Ridgeway and Port 
Colborne; also in the Hamilton group at Bartlett's Mills, near Arkona, Township of Bosanquet.

\section{Retepora Phillipsi (Nicholson).}

\section{Retepora Phillipsi (Nicholson), Geological Magazine, April, 1874.}

Polyzoary infundibuliform, or forming a flattened expansion. Branches slender, fifteen to eighteen in a quarter of an inch measured transversely, parallel, flexuous, not united by dissepiments, but coalescing at intervals of about a third of a line, and over spaces of the same length. Fenestrules oval, six or seven in the space of a quarter of an inch measured vertically, seven or eight in the same space measured diagonally (five in two lines on an average), regularly alternate in contiguous rows. Cells in two alternating rows upon each branch, the rows separated in decorticated specimens by a distinct impressed line. Three cells to the length of a fenestrule, sometimes only two, and one or two opposite the points where the branches coalesce. Reverse unknown.
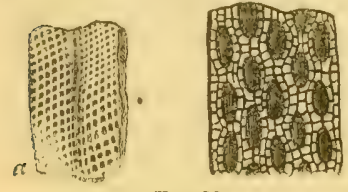

Fig. 39 .

a. Fragment of Retepora Phillipsi, (Nich.) natural size; $b$, Fragment of the same in which the outer non-celluliferous layer has been removed, showing the beaks of the cells, enlarged. From the Corniferous Limestone.

\section{(Canadian Journal, Vol. XIV., No. 2, and Annals of Nat. History, Feb. 1874.)}

Polyzoary forming a rigid infundibuliform calcareous expansion, springing trom a strong, solid, branching foot-stalk or rhizome. Exterior. of the cœnœcium, forming a continuous, non-perforated, thin, calcareous membrane, internal to which is a second or intermediate layer, the two being composed of the amalgamated or coalescent branches ("interstices"). This intermediate layer is marked by shallow longitudinal and bifureating sulci corresponding with the lines between the branches, and its surface exhibits reticulating lines which correspond with the bases or proximal ends of the cells. The internal surface of the intermediate layer carries the cells, which are flask-shaped, and are arranged in double rows, forming recrularly flexuous lines, enclosing oval interspaces, exactly as in Retepora. The oval interspaces, however, instead of constituting so many "fenestrules," are the bases of so many pillars, which proceed perpendicularly inwards, across a central space, to join with an internal calcareous membrane which forms the innermost lining of the funnel-shaped frond.

It follows from the above description that the mouths of the cells in Cryptopora, neither open on the exterior of the froud, as is commonly the case in Fenestella, nor open on the
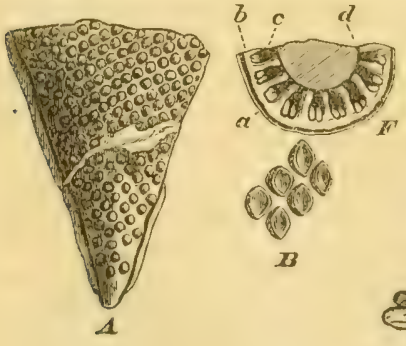

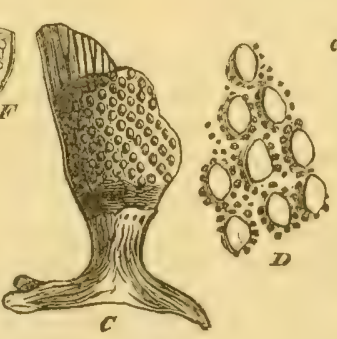

FIG. 40.

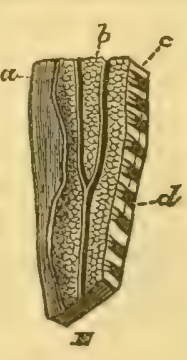

Craptopora mabilis (Nicholson) - A. A partially decortieated specimen, uatural size; B. A small portion of the same, showing the inner ends of the perfendicular colmmns enlaryed : $C$. Another partially decorticated specimen, springing from a strong foot-stalk, natural size; $D$. Part of tho interiur surface of the intermediate laser, showing the mouths of the cellules and the broken perpendicular columns, enlarged; $E$. A small portion of the fromd srcatly enlarged, and somewhat diarrammatically represented; $F$. Transwerse section of part of the frond enlarged, and also represented in a slightly diagrammatic mamer; $\alpha$. The external inembrane; $b$. The intermediate suleated layer; $c$. The ecutral space containing the cells and traversed by the perpendicular columns; $d$. The internal membrane. interior of the polyzoary, as is the case in the infundibuliform species of Retepora. On the contrary, we have in this extraordinary gen. us the entirely unique arrangement that both the internal and external aspects of the funnel-shaped frond are to all appearance closed by a continuous -calca reous membrane. The cells are not placed upon either of the free surfaces of the polozoary, but occupy a central 
space, which has its internal wall formed by the innermost membrane and its external wall by an intermediate layer composed of the laterally-coalescent branches. The cells are situated upon the internal face of the outer layer of this central space (i.e. the intermediate layer); and the two layers are kept apart by a system of pillars which are attached by their inner ends to the internal layer and by their outer ends to the intermediate layer. These pillars traverse the central space perpendicularly, and correspond with the fenestrules of a Retepora. The water must have been admitted to the central space, and thus to the cells, by openings in the free edge of the infundibulifurm polyzoary, but none of our specimens exhibit this portion of the frond.

In the genus Hemitrypo, (Phillips), the fenestrules do not perforate the frond so as to reach the outer face of the polyzoary, but are filled up by a calcified membrane. The cells, however, open upon the external surface, instead of into a central space, and the structure of the cœnocium is in other respects very different.

The following is the only species of the genus which I have as yet'met with:-

\section{Crytopora mirabilis (Nicholson).}

Cryptopora mirabilis, Nicholson, Annals of Nat. Hist., Feb. 1874.

Polyzoary infundibuliform, apparently from nne to three inches in height. External layer, thin, imperforate, smooth, or obscurely striated. Intermediate layer formed of the coalescent branches, marked by vertical grooves or sulci, which are placed about half a line apart, and sometimes bifurcate. Besides these grooves, the outside of the intermediate layer is marked by inosculating lines, which map out small oval or polygonal spaces.corresponding with the cells beneath. The inner surfice of the intermediate layer carries the cel!s, which are arranged biserially in flexuous lines, and enclose ovial or rhomboidal interspaces. These interspaces are disposed in very regular diagonal lines, about four in the space of two lines, and they give origin to a series of short rounded pillars which extend inwards at right angles to meet the internal layer. Central space in which the cells are situated about half a line to two-thirds of a line in depth. Internal layer thin and membranous. The entire frond springs from an exceedingly strong, horizontal, branched stalk, the surface of which is marked by vermicular striæ.

The materials in my hands are not sufficient to permit of an entirely full elucidation and illustration of the characters and structure of this remarkable species. Different specimeus, however, or different parts of the same specimen, show the following appearances (Fig. 40 ):-

1. The external membrame is very thin, and is only preserved in part in any specimen that I have seen. It corresponds with the reverse or non-poriferous layer of an ordinary lietiforn, and in reality is to be regarded as nothing more than the exterior portion of the intermediate or celluliferous layer. Nothing, in fict, is commoner than to meet with precisely similar specimens of lietemin in which the reverse has been stripped off, and the bases of the cells are thus exposed to view.

2. The intermediate layer (together with the external layer, as just remarked) is clearly formed by the coalescence of the branches. When viewed from the outside (Fig. 40, E. b) it exhibits shallow vertical grooves marking out the original branches, and it also shows the outline of the cells below.

3. The structure of the interior of the intermediate layer, and of the central space of which it forms the outer boundary, can be studied in specimeus which exhibit the inner surface of the funvel, or in those which have been broken across transversely. In specimens which show the interior, and from which the innermost layer bas been removed in whole or in part, we see the mouths of the cells, as rounded pores placed on the inner aspect of the intermediate layer (Fig. $40 \mathrm{~J}$ ). 'The cells are arranced in double rows, forming regularly bent or undulating lives, which correspond with the inner faces of the branches, and which enclose the oval spaces which correspond with the fenestrules, just as in Rete prur. When we look, however, at a specimen which is broken across (Fig. $40 F$.), it is seen that instead of perforations between the inosculating branches, we have a series of stout pillars, which run perpendicularly inwards from the poriferous face, and have their inteinal ends connected together by a thin calcareous membrane, which forms the innermost lining of the funnelshaped frond. There is thus formed a continuous central space, which is lined outwardly by the cells, and to which water must have been admitted by the opening in the margin of the funnel. 
4. Specimens which are easts of the interior of the frond, to which the innermost membrane with the ends of the perpendicular columns still remain attached, are not uncommon (Fig. $40 A \& C$ ). These show that the columns are arranged in beautifully regular diagonal lines; and their inner ends seem to have been convex, as they leave in many cases concave or cupped scars, of an oval or rhomboidal shape, upon the outside of the east (Fig. $40 \mathrm{~B}$ ).

5. One specimen exhibits a strong horizontal foot-stalk, from which the frond grew up vertically (Fig. $40 \mathrm{C}$ ). This foot-stalk is branched at both ends, its surface is covered in parts with vermicular strix, and its structure appears to have been minutely tubular or cellular.

6. Lastly, some specimens appear to show the extraordinary character of a second frond, quite similar in structure to the first, invaginated within the outer one, so as to give rise to an internal cone closely applied to the internal surface of the external funnel. It is possible, however, that this appearance may admit of some other interpretation.

I have treated this species at some length on account of its very remarkable and complicated structure; but there are still several points connected with it which I have been unable to make out with my present materials. Specimens are by no means particularly rare, but I have seen none which are not fragmentary. Wainfleet.

Lnculity and Formation.-Corniferous Limestone of Port Colborne and Lot 6, Con. 1,

\section{Genus Fenestella (Lonsdale).}

Polyzoary forming a calcareous, flattened or infundibuliform expansion, composed of subparallel branches, which radiate from the base, and are united laterally by cross-bars or dissepiments, so as to form a network, the meshes of which are in general more or less oblong or sub-quadrate. One surface of the branches (in the infundibuliform species the inner surface) is rounded and covered by a dense, striated or minutely porous layer. The opposite surface of the branches (in the infundibuliform species the oute' 7 surface) is furnished with two rows of short tubular cells, the mouths of which are separated by a more or less prominent carina or keel. The dissepiments are usually without cells. Occasionally a row of small cells upon the mesial keel (the Fenestrellina of D'Orbigny).

Fenestrla differs from Retepor' in possessing distinct dissepiments, and in not having the fenestrules formed simply by the coalescence of the branches; whilst the cells are separated by a distinct keel. From Polypon'e (McCoy), Fenestelle is separated by having only two principal rows of cells, and usually only these two, the third row if present being very minute, whilst the lines of cells are separated by a carina.

The following species of Fenestelle occur in the Corniferous Limestone and the Hamilton group of Western Ontario ; though there are others which cannot be determined until more complete materials shall have been collected.

\section{Fenestella magnifica (Nicholson).}

Polyzoary forming a flattened expansion of unknown but apparently considerable size. Branches almost perfectly straight, bifurcating at intervals of from une quarter of an inch to
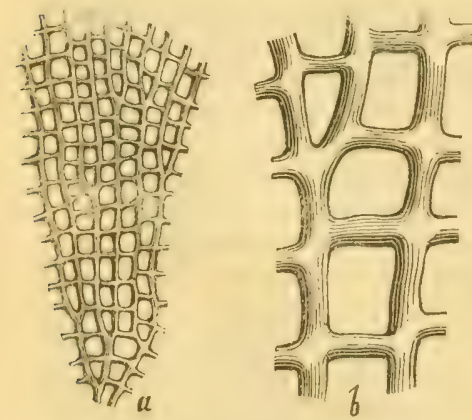

Fig. 41.

a, Portion of the polyzoary of Fenestella magnifiea (Nich.), natural size; $b$. a fragment of the same enlarged. From the Curniferous Limestone. one inch, nearly parallel, united by straight transverse dissepiments, sub-ansular or obtusely carinated and closely striated on the non-celluliferous side. About four branches in the space of a quarter of an inch measured across the frond. Dissepiments about the same in diameter as the branches, usually placed at intervals of from one line to a tenth of an inch apart. Fenestrules oblong, rectangular, nearly equal, from one line to one-tenth of an inch in length by two-thirds of a line in width, nine in one inch measured vertically, and twelve in the same space measured diagonally, placed nearly but not quite at the same level in contiguous rows. Celluliferous face unknown.

This species (Fig. 4l) is most nearly allied to Fenestella laxa (Phillips), from the Carboniferous and Deronian Rocks of Britain; but it is readily distingruished by the regular dimensions of the fenestrules, their rectangular shape, and their much smaller size. (The fenestrules 
in F. lara are from two to four times as large as those of $F$. marmific $)$. From Polypora (Gorgomu) ripisteria (Goldfuss), the present species is separated by its rectangular, not oval, fenestrules, the much greater proportionate and absolute width of the fenestrules, and the straight, not flexuous, branches.

I have only seen a single specimen of $F$. mugnifica, and that only exhibits the reverse of the coenosium; but the general characters of the frond are so unlike any previously recorded species of Fenestrlla with which I am acquainted, that I have thought myself justified in forming a new species for its reception.

Locality and Formation.-Corniferous Limestone of Port Colborne.

\section{Fenestella imarginalis (Nicholson).}

Polyzoary forming a fan-shaped expansion, of unknown dimensions. Branches straight, nearly parallel, about four in the space of two lines. Dissepiments exceedingly narrow, not more than one hundredth of an inch in width, slightly expanded at their points of junction with the branches, quite straight, and separated by intervals of one line, slightly alternating in contiguous rows. No cells upon the dissepiments. Fenestrules oblong, regularly rectangular, nearly twice as long as wide, (nearly one line in length and less than half a line in width); three fenestrules in a quarter of an inch measured vertically, and fire in the same space measured trinsversely. Two marcinal rows of large flask-shaped cells, between which are two or sometimes three rows of minute elonerated cells, which probably oceupied a central keel. Four large cells to a fenestrule, and one at the origin of each dissepiment. As in the case of the preceding species, I have only a single fragmentary example of this species, but its characters are so peeuliar that $I$ have no doubt as to its specific distinctness. Gur specimen is one exhibiting the back of the pmlyzoary, but the outer striated non-celluliferous layer has been denuded, and the proximal ends of the cells are thus brought into view.

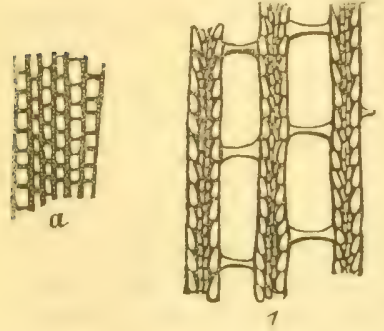

Fig. 42.

In its general form $F$. marginalis is clearly a genuine Fenestella, as shown by the straight branches, the distinct straight non-celluliferous dissepiments, its rectangular fenestrules, and its possession of a row of large cells on each side of each branch. This last character separates it from Polypora, and the others distinguish it from Retepora. The specimen does not enable one to affirm with certainty that the two lateral rows of cells were separated by a median keel, but it appears highly probable that this was the case. In the genus or sub-genus F'enestrellina (D'Orbigny), the

Fonestella marminalis (Nich). a. I framment, natn. mesial keel separating the two lateral rows of large
al size; $b$. A nortion of the same magnified ; c. A portion cells, carrics a central row of minute cells. In

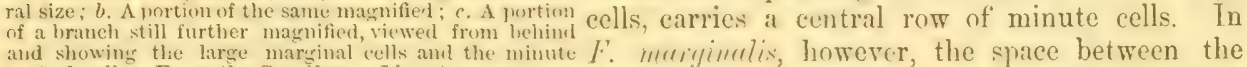
and showint the large maryinal cells ant the minute $F$. muiginulis, howerer, the space between the
central cells. From the Corniferous Limestone. lateral rows of cells carries a series of minute closely-crowded cells, which are arranged in general in two alternating rows, but sometimes in three. This character, so far as I am aware, has not hitherto been observed in any species of Frnestella except $F$. righthl ( $\mathrm{IcCOy}$ ), and it may, perhaps, afford a ground of subgeneric distinction. If, as is most probable, a median keel were present, it must have exhibited the openings of two or three rows of minute cells.

In its general form, $F$. marimulis exhibits some resemblance to F. magnifirr (Nich.), but its dimensions are much smaller. The former has four branches in a space of two lines, and five fenestrules in a puarter of an inch measured transversely, whilst the dissepiments are exceedingly thin, and the length of the fenestrules is nearly double the width. On the other hand, in $F$. magnifiec there are three branches in a space of two lines, and about three fenestrules in a quarter of an inch measured diagonally or transversely, whilst the dissepiments are about as thick as the branches, and the fenestrules are ouly slightly longer than wide.

Locality and Formation.-Corniferous Limestone, Port Colborne. 


\section{Fenestella cribrosa (Hail).}

Fenestella cribrosa (Hall), Pal. N. Y., Vol. II., p. 166, Pl. XL., figs. $3 a, 3 b$.

Polyzoary forming a flattened expansion of unknown dimensions. Branches strong, parallel, often undivided for a distance of half an inch or more, very closely approximated, fifteen or eighteen in a quarter of an inch. Dissepiments about the same width as the branches, or slightly narrower, not dilated at their points of junction with the branches. Fenestrules opposite, sub-alternate, or alternate in contiguous rows, oval or quadrangular, one-third longer than wide. From ten to twelve fenestrules in a quarter of an inch measured vertically, and from fifteen to eighteen in the same space measured transversely. Non-poriferous side closely and finely granulated and striated. On the poriferous side, both the branches and the dissepiments are keeled with a prominent and very sharp carina, and the dissepiments are placed upon a lower plane than the branches, so that in many cases the latter alone are visible. Two rows of cellules on each branch, opening by comparatively large rounded apertures on the lateral aspects of the brancb. No pores on the mesial keel or on the dissepiments. Two pores to the length of a fenestrule, and one opposite the base of each dissepiment.

I have no doubt as to the identity of our specimens with Fenestella cribrosa (Hall), from the Niagara Limestone, though Hall's description embraces only the non-celluliferous side.
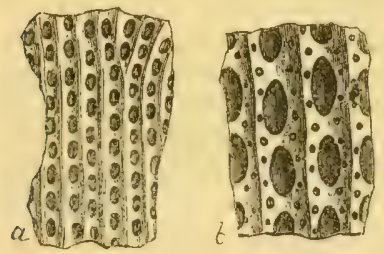

Fig. 43,

a Fracment of the non-celluliferous side of Fenestella cribrosa (Hall), en- tol larged; $b$ fragment of the celluliferous Township of Bosanquet
side of the same enlarged. From the Tomilton Group.
Hamila

Hamilton Group.

The species is quite readily distinguished from all other known species of the genus by the approximation of the slender branches and dissepiments, from which it results that an extraordinarily large number of fenestrules occupy a given space, whether measured vertically or transversely. The characters of the celluliferous side are also sufficiently distinctive. Some examples exhibit proportions slightly larger than those given in the above description, and these may possibly constitute a distinct variety or even a distinct species.

Tocality and Formation.-Not uncommon in the Hamilton Group at Widder, and at Bartlett's Mills, near Arkona,

\section{Fenestella tendiceps (Hall).}

\section{Fenestella prisca (?) (Hall), Pal. N. Y., Vol. II. p. 50, Pl. XIX., Fig. 4, $a-m$.}

Fenestella tenuiceps (Hall), Pal. N. Y., Vol. II. p. 165, Pl. XL. D, Fig, 2, $a-h$.

Polyzoary infundibuliform or forming a flattened expansion of a fan-shaped figure. Branches nearly straight, sub-parallel, increasing by bifurcation, which usually takes place at intervals of two or three lines, though sometimes the branches remain undivided for half an inch or more. From eight to ten branches in the space of one quarter of an inch. Dissepiments slightly uarrower than the branches, markedly expanded at both ends, and separated by intervals of a third of a line or rather more. Fenestrules oval, not distinctly rectangular, nearly or quite twice as long as wide, about six or seven in a quarter of an inch, measured vertically, and from eight to ten in the same space measured transversely, sub-alternate or alternate in contiguous rows. Non.celluliferous surface, finely striated. Cells in a double row ou' each branch, about four to each fenestrule.

Specimens conforming to the above characters are of

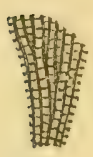

$a$

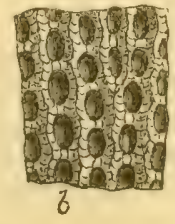

Fig. 44.

Fenestella tenuicer)s (Hall), a frac ment of the natural size; $b$ part of the same enlarged. From the Corniferous Limestone. common occurrence in both the Corniferous Limestone and the Hamilton Formation of Western Ontario, and little doubt can be entertained as to their identity with the species described by Hall under the name of $F$. tenuiceps, from the Clinton and Niagara Formations of the State of New York. Though several of our specimens, by decortication of the non-poriferous layer, show the proximal ends of the biserial cells, none of them actually exhibit the celluliferous face of the polyzoary. According to Hall, however, the branches are strongly cariuate on this aspeet, with a sharp-edged keel, and the cells open on the sides of the branches. 
In many respects $F$. temuiceps (Hall) very closely approximates to $F$. plebeia (McCoy), from the Carboniferous and Devo sian Rocks of Britain, the chief difference of importance being that the fenestrules in the latter are si id to be rectıngular, whereas they are oval in the former. I should doubt if the two forms are specifically distinet.

I.aculity and Formation.-Abundant in the Corniferous Limestone of Port Colborne, Ridgeway, and Lot 6, Con. 1. Wainfleet. Also common in the Hamilton Formation at Bartlett's Mills, near Arkona, Tornship of Bosanquet.

\section{Fenestella filiformis (Nicholson).}

Polyzoary exceedingly delicate, composed of parallel, extremely narrow branches, about fifteen or sixteen of which occupy the space of one quarter of an inch. Dissepiments threadlike, narrower than the branches, expanded at their points of junction with the branches, separated by intervals of about $\frac{1}{1: 0}$ inch. Fenestrules one-third wider than long, rectangular or transversely oblong, twenty-four in the space of one quarter of an inch measured vertically, and about fifteen in the same space measured transversely. Celluliferous side unknown.

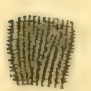

a

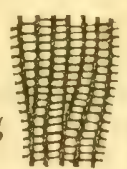

Fir. 45.

I have only fragments of this species, and none of these show the celluliferous aspect; but the proportions of the polyzoary are so entirely distinct from all other previously recorded species of the genus, that no doubt can be entertained as to its being new. It is very readily distinguished by its filiform and closely-set branches, by the unusual character that the fenestrules are markedly wider than Fragment of Fenestella long, and by the extraordinarily large number of fenestrules in a

6 portion of the same magni- given space measured vertically.
fied. From the Corniferous given Limestone.

Locality and Formatim.-Corniferous Limestone, ìot 6, Concession 1, Wainfleet.

\section{Genus Tæniopora (Nicholson).}

Canadian Journal, Vol. XVI., No. 2, and Geological Magaztne, March, 1874.

Polyzoary calcareous, composed of a flattened, linear expansion, which branches dichotomously and is celluliferous on both sides. Fiach side of the polyzoary (sometimes one side only ?) is furnished with a strong median ridge or keel, which has a longitudinal direction, and separates the froud into two lateral halves. The cells have prominent mouths, and are arranged in from three to five longitudinal rows on each side of the central keel ; the cells of contiguous rows alternating, so that a series of short oblique rows of cells are produeed which diverge from the keel like the barbs of a feather. The margins of the polyzoary are usually
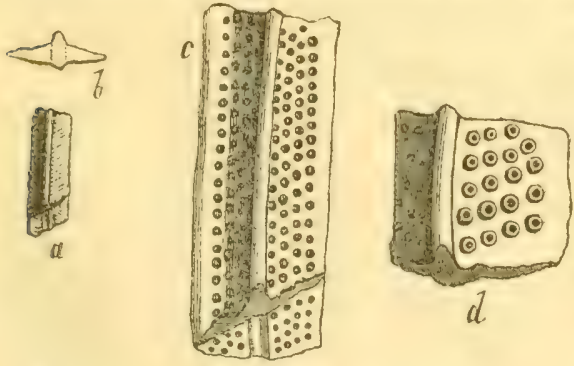

FIG. 46.

a. Fragment of Toniopora penniformis (Nich.) natural size; $\ell$. Transverse section of the same enlarged; $c$. Fragment of the same enlarged; $d$. Fragment still further enlaried, showing the prominent mouths of the cells. From the Hamilton Formation. alone warraut generic distinction. One of the chief characters of Ptilodictme is the presence of a flattened laminar striated axis separating the two celluliferous aspects of the polyzoary. I have not been able to establish clearly either the presence or absence of such an axis in T'm. mimpra, but my specimens lead me to believe that it is absent, and that there is instead, a ver- 
tical septum, traversing the short diameter of the frond, and prolonged on either side into a kecl. Leaving this point, however, out of the question, as uncertain. there remain the following differences:--1. In Ptiludictya the cells are not furnished with prominent mouths, but with depressed apertures, and these are arranged in rows, which are separated by distinct thread-like elevated lines or strias. On the other hand, the cells of Tienioporil have prominent pustuliform openings, and they are usually not separated by any lines or ridges of any kind. In some examples from the Hamilton group of the State of New York, the first row of cells on either side of the keel has a limiting thread-like liue, but I cannot detect any such structure in our Canadian specimens; and even the former have the remaining rows of cells not marked off in this way. 2. There is no mesial keel or elevated ridge in Ptiloditya, separating the conocium into two symmetrical lateral halves. On the other hand, the most conspicuous feature in l'emionoma is a strong elevated I ngitudinal carina on either side of which the cells are arranged in alternating lines. 3. Whilst some examples of Tuniopore show a distinet non celluliferous marginal zone on either side, as exists in Ptiledictya, others do not appear to possess any such structure; and in any case this zone appears. when present, to be smooth and not striated. Upon the whole, therefore, whilst recognizing the ceneral affinities of Tieniopora to Ptilodictya, I think the former may safely be regarded as a distinct genus.

The following two species of Teniopor have come under my notice as occurring in the IJamilton group; but as all my specimens are fragmentary, there are several important points connected with their structure, which I have found myself unable to elucidate. I have also specimens from the same formation in the State of New York, some of which appear to be identical with one of our Canadian species, whilst others present certain differences which may perhaps be of specific value.

\section{Thiopora exigua (Nicholson).}

Treniopora exigua (Nicholson), Geological MTagazine, March, 1874.

Polyzoary forming flattened linear expansions, which branch dichotomously at angles of about $60^{\circ}$ and at intervals of from one and a half to three lines. The width of the frond is about a line or a little over, and its thickness in the centre is about one-third of a line, from which point it rapidly diminishes in thickness, until the sharpeded literal margins are reached. Both sides of the cenocium carry a well marked longitudinal ridge or keel, which occupies a mesial position, and on either side of which are thee or four lungitudinal rows of cclls. The cells are alternately disposed in contiguous rows, so as to form a series of short transverse obliquely uscending lines, consisting each of three or four cells. The cells are inmersed in the substance of the cencecium, and their mouths are circular and prominently elevated above the general surface. About six cells occupy the space of one line measured longitudinally, and the intervals between them are equal to or slightly greater than the diameter of the eell mouths themselves. The cells extend on either side of the midrib, quite to the edge of the conocium, and there appears to be no marginal non-celluliferous zone.
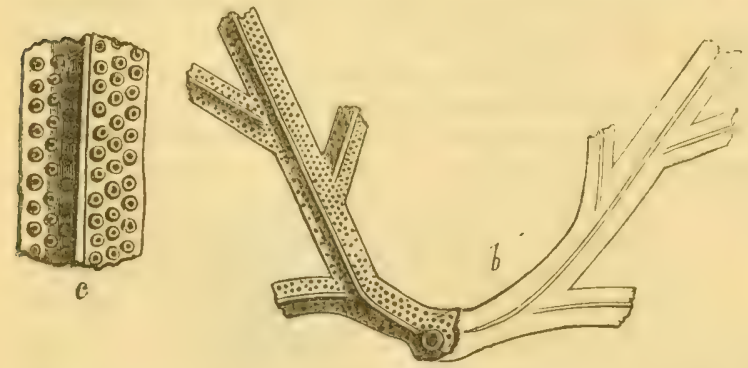

Fig. 47.

From the following species, T'aniopora exigua is distinguished by its much smaller width, its more frequent division, its much less strongly elevated mesial keel, and the apparent absence of any distinct noncelluliferous marginal area.

$\$$ One specimen exhibits at the base a small conical expansion from which the

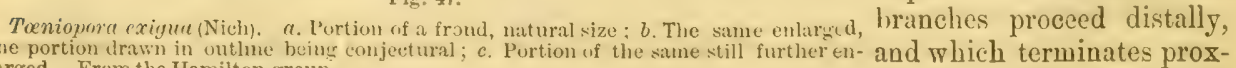
larged. From the Hamilton group.
imally in a singular, and clearly natural, circular perforation of about one-fourth of a line in diameter. There are also indications in this specimen ( fig. 476 .) that the branches of the frond were bilaterally or 
radially disposed round this central point. It is to be regretted, however, that, with the imperfect materials at my command, I am at present compelled to leave this and other points of interest in the structure of this remarkable form unelucidated.

Lirrelity ame Frmmalim. - Common in the Hamilton group, at Bartlett's Mills, near Arkona, Township of Bosanquet. (Al:o common in the Hamilton Shales, at Canandaigua. State of New York.)

\section{3. 'Tentopora PENNIFORMIS (Nicholson).}

Teniopora penniformis (Nicholson), Genlogical Magazine, March, 1874.

Polyzoars forming a linear flattened expansion, which probably divides dichotomonsly. The total width of the frond is abont two lines, and its thichness in the middle is about twothind of a line. gradually tapering to the maryin. Both sides of the conocium (onecertainly: and the other probably) are furnished with an exceedingly strong. blunt, mesial, longitudinal ridge or keel, the height of which is about a fourth of a line and its thicknes: about the same. On either side of the central keel are four rows of cells in alternating liues. The mouths of the cells are circular and promineut, ab ut five or six necuppine the space of one line measured longitudinally. Outside the rows of cells ou either side is a flain non-celluliferous space, about one-third of a line in width, by which the margin is constituted.

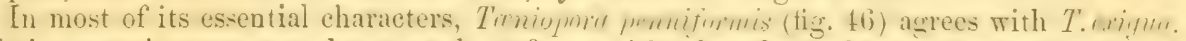
but it is a much stronerer and more robust form. with a broader and more elerated keel, and possessing a marginal non-poriferous area which alpears to be wantiug in the latter. I have only fragments of the species, and am unable to state anything as to its general form of growth or its total dimensions.

Lurulity and Furmutim.-IIamilton Formation. Rartlett's Mills, nes r Arkona. Township of Bosanquet.

\section{Gemus ('arinopora (Nicholson).}

\section{(Canadian Journal, Vol. XIV., No. 2, and Annals of Nat. Hist., Feb. 1874.)}

Polyzoary infundibuliform, calcareous, and reticulated. The external layer of the crathiform frond is composed of resularly undulated flexuous branches which anastomose with

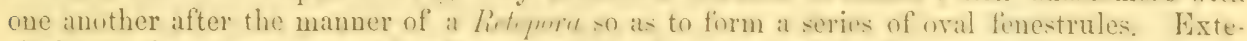
riorly, the bramches are anculated or carinate and are smouth and non-celluliferous. Inter-

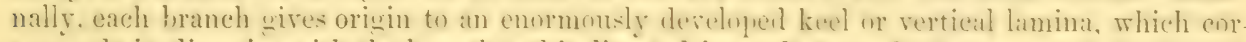
responds in direction with the branch and is direced iuwark towards the centre of the funnel.

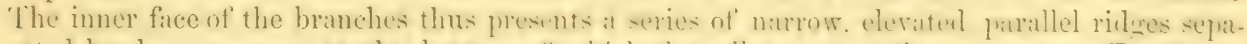

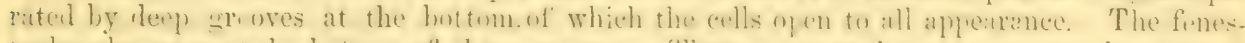

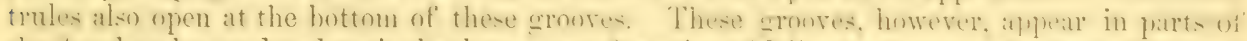
the frond to be rendered re-icular by means of a series of deileate calcaremus lamine which con-
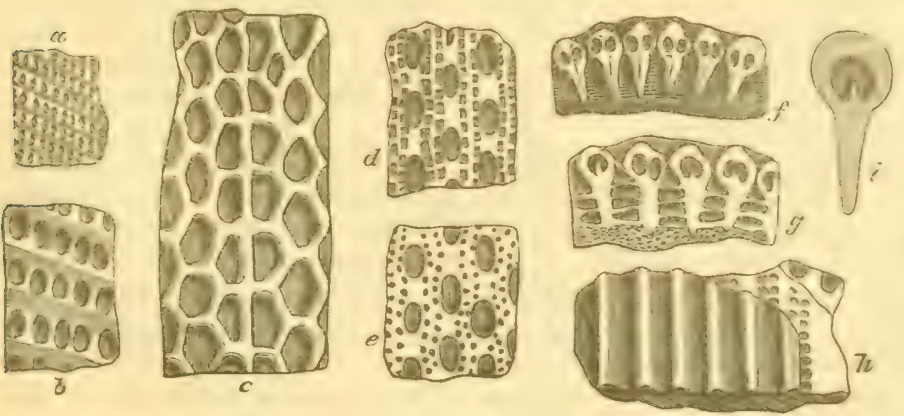

Fig. 48 .

Tllustrations of the structure of Carinonora Hindei, (Nich). a. frament of the exterior,

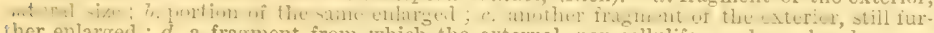
ther enlarged; $d$. a fragment from which the extelnal non-celluliferous layer has been re-

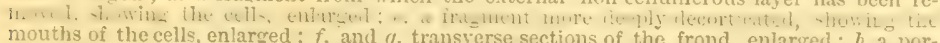
mouths of the cells, enlarged; $f$, and $g$. transverse sections of the frond, enlarged; $h$. a por-

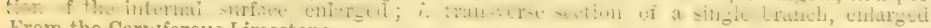
From the Corufferous Limestone. nect together the oppcsing sides of contiguous ridees. In some cases also, the inner ends of the ridges are connected together by a continuous calcareous membrane, so that the inner surface of the frond is completely closed. The cells are carried in alternating double rows upon the inner surface of each branch, their moutbs appearing to besituatrol it the bittem of the gronves afore-mention. ed and at the base of 
the great keel which springs from each branch internally. No cells are carried by the areas formed by the anastomosis of contiguous branches

I have only seen a single, very large and well preserved example of this genus, and a careful examination of this has still left me entirely unable to elucidate and explain some of the most extraordinary structural featuresw hich it presents. There can, however, be no doubt as to the complete distinctness of the genus from any previously known. A comprehension of the very remarkable characters presented by this genus will perhaps be best obtained from a detailed account of the different figures of the above illustration, all of which represent different portions of the only known specimen.

a. This figure exhibits a portion of the exterior of the frond, showing the fenestrules and the outer non-celluliferous aspect of the branches. In the portion here illustrated of the natural size, and partially shown at $b$ on an enlarged scule, the fenestrules are oval, and arranged in diagonal lines, and the branches are strongly keeled; the general appearance closely resembling the non-celluliferous aspect of Retepori mrisea (Goldfuss), and the fenestrules being formed in the same way by the simple inosculation of the branches, without the development of distinct dissepiments. c. This represents another portion of the exterior of the frond, near the base, where the fenestrules are polygonal and are not arranged in regular diagonal lines. In some cases, the fenestrules present the appearance of being closed by a delicate external membrane.

d. This figure shows a small portion from which the outer non-celluliferous layer of the branches has been stripped off, showing the proximal endis or bases of the cells, arranged in a double inosculating row on each branch, and lying in the same plane as the fenestrules.

$e$. This figure exhibits, on an enlarged scale, as small portion of the exterior of the frond from which the outer non-celluliferous layer and the cells themselves have been stripped away, leaving to view the circular mouths of the cells arranged in two alternating rows, which are still in the same plane as the fenestrules, and which do not encroach upon the spaces formed by the inosculation of the branches.

$f$. This figure is a greatly magnified representation of a transverse section of the frond at a point considerably removed from the base, showing the branches cut across. Above, the branches are separated by the fenestrules, and immediately beneath this are seen the dark oval spaces contained within the body of each branch, a pair in each, and representing the cavities of the biserial cells. Below this, again, each branch is seen to give origin to an immense vertical keel or ridge, which is directed inwards towards the interior of the frond. These ridges are separated by deep intervening grooves; and there can be doubt that the cells open at the bottom of these groves, those of one side of the branch opening on one side of the base of the great keel, and those of the other opening upon the opposite side of the same.

g. This exhibits a greatly magnified transverse section of the frond at a point a little above the base. As in the preceding, we can recognise without difficulty the shallow fenestrules, the divided branches carrying in their interior, each, a pair of cells, and the great internal keels. Hure, however, we have two new features. Firstly, the deep grooves between the keels are sub-divided by delicate calcareous laminæe which connect the opposite side of contiguous keels, and divide the intervening grooves into shallow transverse chambers. Secondly, the grooves between the keels are closed internally by a continuous calcareous membrane, which has a minutely porous or vesicular structure.

$h$. This exhibits a fragment taken from near the base, and showing the internal surface. We see here the inner faces of the great longitudinal keels, separated by shallow grooves which are filled up by a continuous calcareous membrane, which is not penetrated by either the fenestrules or the cells. No apertures, therefore, of any kind appear on the interior of the frond near the base. In the upper portion of the frond, however, a fragment of the interior exhibits simply the great keels with deep intervening grooves, and the layer connecting the keels cannot be distinctly made out. At the right hand corner of $h$, the keels and their con. necting membrane are broken away, and we see the cavities of the rows of cells; whilst the extreme corner is still further broken away, so that the fenestrules comes into view.

$i$. This simply represents a single branch in transverse section, greatly enlarged, and shows the cells in the interior of the branch, and the great triangular keel proceeding from its internal surface.

From the above description, it will be evident that the structure of Carinopora is quite anomolous, and wholly unlike anything that has been hitherto observed in any member of the 
Fenestellicle. The most anomalous point is the position of the cells, or rather their mode of opening on the surface. The frond is funnel-shaped, and the cells open towards the interior of the funnel, as in Retepora. 'Towards the upper portion of the frond, the cells seem to open simply at the bottom of the deep grooves between the internal keels, and the fenestrules open into the same grooves, and there is, therefore, no special difficulty here, if, as seems tolerably certain, the keels are not here connected by an imperforate connecting membrane, and the grooves thus remain open to the access of sea-water; near the base, however, the keels are clearly connected internally by a membrane which has no perforations in it, and the deep intervening grooves are filled up by a vesicular calcarous tissue, so that the sea-water could not have gained access to the mouths of the cells. The only explanation that I can offer, is that the basal portion of the polyzoary may perhaps have been gradually overgrown internally by this layer of vesicular tissue, and may thus have been practically killed, whilst the upper portion remained open to the sea, and genuinely alive. If this be not the case, I cannot explain the undoubted facts.

The enormous internal keels, whether free or connected together internally give an extraordinary depth and thickness to the polyzoary, and the fenestrules do not extend to more than about a fourth of this depth, nor do the cells. In Hemitrypa (Phill.) the fenestrules do not extend through the entire thickness of the polyzoary, but in this genus the fenestrules are confined to the inner surface of the funuel-shaped frond, and the cells open caternully. In ('ryptripora (Nich.) again, the outer and inner surface of the polyzoary are both imperforate, aud the cells open internally into a central space which is crossed by regularly-placed pillars, having a direction perpendicular to the plane of the frond. notice :-

The following is the only species of the genus Carinopora, which has come under my

\section{Carinopora hindei (Nicholson).}

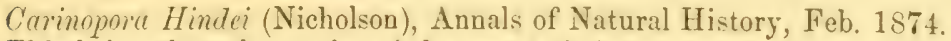

This being the only species of the genus, it is unnecessary to recapitulate its structural characters, since these, so far as known, have been fully discussed above. It only remains to give the measurements by which the species is distinguished, along with one or two characters which are not of generic value. The only known specimen exhibits a portion of a very large infundibuliform frond, which, though fragmentary, has a height of four inches, with a diameter above of clearly more than half a foot. The actual base is bronen off. About six branches occupy the space of two lines. The fenestrules are sometimes oval, sometimes hexagonal or polygonal, and their arrangement differs in different parts of the frond. Sometimes they are arranged in regular diagonal lines; but even in this case there are often perceptible central longitudinal lines, on either side of which the diagonal rows of fenestrules diverge in opposite directions, like the barbs of a feather, giving rise to a most peculiar appearance. At other times the fenestrules are rhomboidal, hexagonal, or polygonal, and are not arranged in distinct diagonal rows; whilst two contiguous longitudinal rows are often separated by an unusually narrow and apparently quite straight branch (See Fig. $48 \mathrm{c}$ ). The spaces along which the flexuous branches inosculate have a depth of about half a line, considerably exceeding the width of the branches; so that whilst seren fenestrules occupy a quarter of an inch measured diagonally, only four occupy the same space measured longitudinally. The thick. ness of the frond, measured at right angles to its plane of growth, is one line or a little more, nearly two-thirds of this being accounted for by the great internal keels. Lastly, there are generally three cell-mouths to the length of a fenestrule, with two placed opposite the inosculation of each pair of contiguous branches.

The only known example of this singular species was discovered by my friend, Mr. George Jennings Hinde, by whom it was submitted to me for examination, and in whose honour I have named it.

Locality and Formation.-Corniferous Iimestone, Jarvis, County of Walpole.

\section{Genus Clathropora (Hall).}

Polyzoary composed of membranous flattened expansions, which either branch without anastomosis, or, more typically, divide into branches which inosculate at short intervals till there is produced a broad frond perforated at regular intervals by rounded or oval fenestrules 
of considerable size. Both sides of the polyzoary carry cells, but the cells which open upon one aspect are separated from those which open on the other side by a thin concentrically-striated laminar axis or membrane, precisely similar to the axis of Ptilodictyc. In the clathrate species the margins of the apertures are surrounded by a strong striated non-celluliferous border.

There can be no doubt as to the very close relationship between Clathropora and Ptilodictyu; and it may reasonably be doubted if the former can be retained apart from the latter. One of the chief characters of Ptilorliclyu is the presence of a thin striated membranous axis between the two series of cells on the two aspects of the cœnœcium. No such character appears to have been observed by Fall in C'luthropora, or is alluded to in his description of this genus, and its absence would certainly be a sufficient ground for generic distinction. I have, how. (.ver, determined the existence of a laminar axis exactly similar to that of Ptitndictyu, both in a Corniferous species of Clathropora and in C. fromdose. (Hall), from the Niagara Limestone, the type-species of the genus. The striated non-celluliferous margins of Ptilodictyu are also represented by precisely similar margins surrounding the fenestræ in both C. frondos" (Hall), and in C. intertextre (Nich.) It would appear, therefore, that the chief difference between Clathropora and Ptilutictya is to be found in the fact that the cells of the latter are arranged in rows separated by distinct elevated lines, which certainly appears not to be the ease in the typical species of the former, though the contrary is asserted by Hall. The mode of growth of Cluthropora in itself clearly does not afford sufficient ground for generic distinction, and the more or less quadrangular form of the cell-mouths is certainly only an occasional phenomenon in the type-form $C$. fronciosa. Upon the whole, therefore, whilst retaining (Tuthropora in deference to the opinion of such a high authority as Prof Hall, I am inclined to believe that the forms included under it may safely be placed under Ptilolictya.

The following species is the only one which has come under my notice as occurring in the Devonian Rocks of Western Ontario.

\section{Clathropora intertexta (Nicholson).}

\section{Clathropora intertexta (Nicholson), Geological Magaine, March, 1874.}

Polyzoary forming a thin flattened expansion, composed of broad branches which inoscu late so closely as to leave simply rounded or oval apertures or fenestra perforating the frond. The width of the brauches is from a line to a line and a half; and the fenestra are oval or circular in shape, about a line and a half or a little more in diameter, and placed at intervals of about a line or a line and a half. The margins of the fenestra are surrounded by a striated non-celluliferous zone. The frond is celluliferous on both sides, forming two continuous linyers. their proximal ends or bases being pliced back to back, but separated by a delicate calcareous membrane or laminar axis, which exhibits numerous elove-set transverse curved stria. From six to ten cells oceupy the sprice of a line mea-ured diagonally, whilst the form of the ecllmoutlis is oval or circular, and the cells do not appear to be arranged in distinet lines separated by elevated strioe.

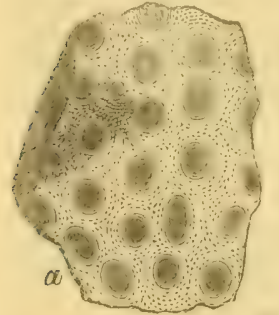

Fis: 19

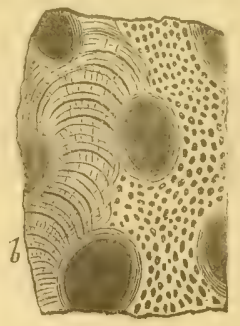

Clalhrumat interefa (

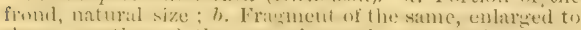
alew a jurtisus of the central membrathums axis. From the Cornifernus Limetrone.

larger fenestrule;, about the same in size as in C: intertertw, though more elliptical. 'This. howerer, can not be considered as belonging to the same species as Fig. 5l, with the smaller fenestra: and as all the specimens I have seen, however large, agree with the chatrater of 
this form, I should be disposed to regard this as the typical form of $C$. frondosa (Hall). In such examples of $C$. frondosa, further, as I have examined, the cells are remarkably long and narrow, and about fourteen of them occupy the space of one line measured transversely; whereas, in $C$. intertexta the cells have a sub-quadate or rounded form, with nearly circular mouths, and only six to eight of them occupy a line transversely. In spite, therefore, of the close general resemblance between $C$. intertexta and the two forms included under Hall's $C$. frondose, I um inclined to think $C$. intertexte to be specifically distinct. If this should subsequently, by a comparison of specimens, be proved not to be the case, I should propose that the name of $C$. frondosa (Hall), should be restricted to the forms with the very small fenestro (Pal. N. Y., Vol. II , Pl. XL., B., fig. 5b.), whilst the name of C. intertexta should be applied to the undoubtedly distinct forms with large fenestræ. In any case, as before remarked, both of these species of Clathropora might, without impropriety, be looked upon as nothing more than reticulated Ptilodictyce.

Loculity and Formation. - Corniferous Limestone of Jarvis, Township of Walpole. (Collected by Mr. George Jennings Hinde).

\section{CHAPTER V.}

\section{LAMELLIBRANCHIATA PTEROPODA, AND GASTEROPODA-OF THE CRNIFEROUS AND HAMILTON FORMATIONS.}

\section{LAMELLIBRANCHIATA.}

Mr. Billings states, that he has met with about twenty species of Lamellibranchiata irs the Corniferous Limestone of Western Ontario, and of these he names and deseribes one, viz. Vanuxemia Tomkinsi (Canadian Journal, New Series, Vol. VI., p. 357). This species I have not seen, and the only Lamellibranch which I have met with, either in the Corniferous Limestone or the Hamilton group, is the well-known Conocurdium trigonule (Hall).

\section{Conocardium trigonale (Hall).}

Pleurorhynchus trigonalis (Hall), Rep. 4th Geol., Dist. New York, p. 272, figs. 6a, 6ש., (not Pleurorhynchus trigonalis, Phillips).

Conocardium sub-trigonale (D'Orbigny), Prodr., Vol. I., p. 80.

Conocurdium trigunule (Meek), Gological Survey of Ohio, Palaontology, Vol. I., p. 201.

Shell trigonal, with the anterior extremity distinctly cordate. "Anterior side abruptly truncated, with a forward slope from the beaks to the more or less angular anterior basas extremity, and flattened, or sometimes even a little concave, near the outer margins, so as to mect the lateral surfaces at about right angles, or less, along the prominent, avgular, umbo nal slopes, which extend to the anterior basal extremity, and are produced forward in the form of a peculiar thin alation, that is most extended below ; dorsal margin behind the beaks nearly straight and horizontal, or a little declining and slightly concave in outline with the edges of the valves incurved, while in front of the beaks it is more or less produced forward in the form of a narrow (beak-like?) extension; basal margins of the valves strongly incurved and distinctly crenate within, nearly straight in outline, anteriorly and obliquely ascending, with a more or less convex outline posteriorly to near the hinge, below which they are widely gaping so as to form an ovate or sub-cordate hiatus, and present a slightly sinuous outline; posterior extremity (when not broken or worn away) distinctly angular at the termination of the hinge-line above; beaks moderately prominent, gibbous, and distinetly incurved nearly at right angles to the hinge, or with a very slight backward inclinatios. Surface ornamented by simple, regular, radiating costæ, separated by furrows of about the Sitme size or less ; costre smaller and more crowled on the anterior flattened face of the valves than on the flanks behind the umbonal angle, and not defined on the anterior umbonal akiztion; crossing all of these markings, there are numerous fine, regular, crowded, concentric 
lines, generally much more distinct in the furrows than on the ribs between them, and more or less marked on the anterior alations; a few stronger wrinkles of growth are also usually seen at more distant intervals, especially near the lower margins of the valves, where they are

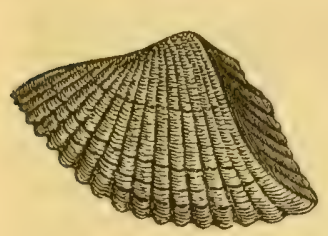

Q

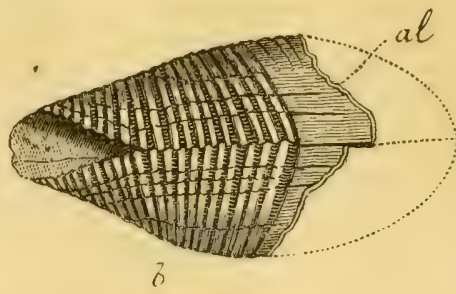

FIG. 50 .

Conocardium trigonale (Hall); $a$. Side view of a medium sized, mature specimen, being mainly an internal cast, with the umhonal alations and the anterior beaklike appendage broken away; $b$. View of the under side of another specimen, retairing a portion of the alation $(a l)$, which extended at least as far forward as indicated $\mathrm{y}$ the dotted line. (After Meek).

Specimens of Conocardium trigonale appear to be common in parts of the Corniferous Limestone, but, so far, I have only met with exceeding fragmentary and broken specimens, though these can readily be recognised by their surface characters, and by the singular alations produced from the margins of the truncated anterior side. I have, therefore, contented myself with simply reproducing Meek's full description and a portion of his figures of this species. If Pleurorhynchus trigonalis (Phillips), be a valid species, and not identical with Conocardium Hibernicum (Sowerby), then the use of the specific name trigonalis, for the American form must be a abandoned, and D'Orbigny's designation of sub-trigonale will have to be adopted.

Locality and Formation.-C Corniferous Limestone of Hagersville, Township of Oneida.

\section{PTEROPODA.}

\section{Tentaculites sp.}

Under this head, I can simply note the occurrence in great abundance in the Hamilton group of a species of Tentaculites, which is probably not new, but which I am unable to identify with any species previously described, in consequence of my not having access to all the published descriptions of these fossils. In almost all respects it agrees with Tentaculites annulatus (Schlotheim) (=T. scalaris ibid), but the latter is described as having the surface covered with very minute longitudinal striæ, no such structures being visible in the former. On the contrary our species agrees with Tentaculites ornatus (Sowerby), in having the interspaces between the regular annulations ringed with from three to seven fine sharp encircling strix. It is, however, apparently not identical with $T$. onnatus, as it seems to be a longer form, and to have the annulations more elosely set. In the absence, however, of authentic specimens of either T. annulatus or T. ornatus, I can simply leave the specific determination of the Canadian form an open question.

Locality and Formation. - Very abundant in the Hamilton Formation, Arkona, Township of Bosanquet.

\section{Gasteropoda.}

The? number of Gasternoda in the Devonian Rocks of Western Canada is very considerable, and this is especially the case as regards the Corniferous Limestone. By far the majority of specimens, however, oc sur in the state of casts, with little or none of the original surface preserved, often crushed, or mutilated in different ways; and it is thus often impossible to determine their true affinities or to decide with certainly to what species they may belong. I have thus been compelled to leave altogether unnoticed a number of univalves of which nothing definite can be made with the materials at present in my hands; whilst the determination of these here recorded must be regarded as more or less doubtful and provisional. The only Gasteropod which has come under my notice from the Hamilton group is a Platyceras, and 
geveral species of the same genus occur in the Corniferous Limestone. The latter formation also contains examples of the genera Platyostome, Strophostylus, Holopea and possibly Helicotomia.

\section{Genus Platyoeras (Conrad).}

"Shells depressed, sub-globose, sub-ovoid, or obliquely sub-conical. Spire small; volutions few, sometimes free and sometimes contiguous, without columclla; aperture more or less expanded, often campanulate and sometimes with the lip reflezed; peristome entire or sinuous. Surface striated or cancellated, often spirally ridged or plicate, and sometimes strongly lamellose transversely, nodose or spiniferous."-(Hall, Pal. N. Y., Vol. III., p. 309).

The shells of the genus Platyceras are readily recognised by their obliquely spiral or straight shape, their wide aperture, their usually or always having a sinus in the outer lip, and the absence of a columella. They may be dextral or sinistral. The genus is identical with Acroculia (Phillips) over which it has the priority, and appears to be most nearly allied to the recent Capulus.

The following species of Platyceras occur in the Corniferous Limestone and Hamilton formation of Western Ontario ; but their determination is rendered uncertain by the imperfect and ill-preserved condition in which they are found.

\section{Platyceras ventricosum (Conrad).}

Platyceras ventricosum (Conrad), Ann. Rep. Pal. N. Y., 1840, p. 206.

Platyceres ventricosum (Hall), Pal. N. Y., Vol. III, Pl. LVI., Figs. 1, \& \& 8, and Pl. LVII, Fig. 4. $4 a, b$.

Platyceras ventricosum (Meek and Worthen), Geology of Illinois, Vol. III, Pl. XI, Figs.

Shell obliquely ovate, composed of two and a half or three volutions of which the last is extraordinary expanded and ventricose. The spire is depressed below the plane of the upper side of the body-whorl, and the inner lip is in contact with the spire. The surface is marked by fine transverse strix, and near the aperture by coarse undulating lines or folds of growth.

I have one or two specimens, of which one is figured in pl. II., fig. 1, which consist of the body-whorl of a large Plutyceras almust certainly to be identified with $P$. ventricosum. None of our examples, however, exhibit the spire.

Locality and Formation.-Corniferous Limestone of Port Colborne.

\section{Platyceras intermedium (Hall)?}

(Plate II., Fig. 2.)

"Shell arcuate, sub-spiral, making little more than two volutions, the last one free and becoming gradually straight. The apcx is very minute, consisting of little more than a single volution, with the parts closely contiguous. Surface marked by fine lamellose transverse strix,

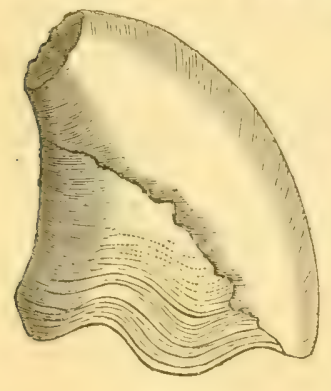

Fig. 51. which are slightly undulated upon the body of the shell."-(Hall, Pal. N.Y., Vol. III, p. 3.21, Pl. LVIII., Fig. II.)

I possess two examples of the body-whorl of a species of Platyceras from the Corniferous Limestone, of which all I can as. sert is that they are of the type of $P$. intermedium (Hall), if not absolutely belonging to the same species. Both consist of the slightly curved and greatly expanded body-whorl, the lip of the aperture being markedly undulated, and the surface exhibiting numerous close-set transverse striæ, which are undulated to correspond with the sinuous aperture, and are very elosely arranged near the aperture is nearly round.

Locality and Formation.-Corniferous Limestone of Port

Body-whorl of a species of Platy. ceras apparently identical with $P$. 
140. Platyceras, sp.

(Plate II., Fig. 6.)

Our collection includes a single very well preserved specimen of the body-whorl of a Platyceras of the type of $P$. bisulcatum (Hall). It is apparently new, but with such meagre materials I do not venture to deseribe it. The body-whorl is free, and the apex has evidently been small, and has apparently been sinistrally rolled up. The aperture is expanded, and the tip is strongly sinuated. Along the convex side of the body-whorl run two longitudinal furrows, of which one is very deep, whilst the other is quite shallow and obscure. Between these is a strong rounded longitudinal rizge or plication. The entire surface is marked with strong, close-set, lamellose, transverse striæ, which do not become any stronger towards the aperture than they are near the apex.

Locality and Formation.--Corniferous Limestone, Lot 6, Con. 1, Wainfleet.

\section{Platyceras, sp.}

(Plate II., Fig. 7).

This is a much crushed specimen resembling $P$. tenuiliratum (Hall), but the true affini ties of which cannot be determined. It consists of two or three volutions, the first and second being extremely minute, and the body-whorl being greatly expanded and lengthened. The minute, inrolled apex is not two lines in diameter, whilst the elongated body-whorl has a length of nearly an inch and a half. The specimen is decorticated, and the surface-characters cannot be made out.

Locality and Formation.-Corniferous Limestone, Ridgeway.

\section{Platyceras uniseriale (Nicholson).}

$$
\text { (Plate II., Fig. 5.) }
$$

Spire small, unknown, but evidently of few volutions. Body-whorl very large, ventricose, expanded towards the aperture. Aperture rounded, its margin sinuated. The margin of the aperture is somewhat oblique, and the spire would appear to have been in contact with the body-volution. The convex aspect of the body-whorl carries upon one side, not mesially, a single row of large remote spines. Surface marked with tolerably conspicuous transverse striæ, which become stronger towards the aperture, and also with very fine longitudinal strix.

I have only a single specimen of this singular form, but its characters are so distinct from those of any species of Platyceras known to me, that I feel justified in describing it as a new species. The specimen exhibits only the body-whorl, with the margin of the aperture and the commencement of the spire. The most noticeable feature, apart from the surfaceornamentation, is the existence of a single row of spines upon one side of the body-whorl, these spines being of larce size, and nlaced very far apart. The specimen only shows two of these spines, and only the bases of these, but they have a diameter of a line and a half, and are placed at four lines apart. As almost the entire surface of the body-whorl is shown, and as the shell itself is preserved, it is certain that no other spines could have been present except those belonging to this series. It thus differs very materially both from the Devonian species of Platyceras, with spines irregularly disposed over the whole surfice, and also from the carboniferous species, $P$. biscriale (Hall), in which the body-whorl is provided on both sides with a row of long spines.

\section{Locality and Formation.-Corniferous Limestone, Port Colborne.}

\section{Platyceras dumosum (Conrad)?}

A small spiniferous species of Platyceras is not uncommon in the Hamilton Formation of Western Ontario, which belongs to the group of which $l^{2}$. dumosum (Conrad) is the type, and which appears to be in all probability a variety of this variable species. It is much 
smaller than the typical forms of $P$. dumosum, and also carries much fewer spines. Upon the whole it seems to be most like $P$. dumosum, var. rarispinum, Hall (Fifteenth Report on the State Cabinet, . 38), though it never appears to attain anything like such a size. It al somewhat resembles $P$. dumosum, var. attenuatum, Meek (Palæontology of Ohio, Vol. I. Il. XX., Figs. $2 a, b$.)

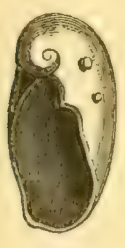

1

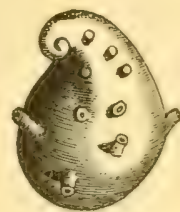

6

Fig. 52.

Different views of a small Platuceras ( $P$. dumo Different views of a small $P$ lotice Formation. Natural size. possible that our shells are new, as they do not appear to corresfond exactly with any previously recorded form; but, in the present condition of the genus Platyceras, it would be unsafe to give it a separate title.

Lecelity and Formution.-Common in the Hamilton Formation, Arkona, Township of Bosanquet.

\section{Genus Pratyostoma (Conrad).}

The shells of this conrenient but hardly definable genus are rentricose, with a short, depressed, or very moderately elcrated spire, and an extremely expanded body-whorl. The aperture is very large, and the columellar lip thickened.

Specimens which appear to have all the characters of $I^{\prime}$. ventringin (Conrad), from the Lower Helderberg and Oriskany Sandstone, are not uncommon in the Corniferous limestone of Ontario; but they occur entirely in the condition of casts, and do not, therefore, permit of anything further than their mere identification.

\section{Platyostoja ventricosa (Conrad).}

$$
\text { (Plate II., Fig. 4.) }
$$

p. 275 .

Platyostoma rentrienses (Conrad), Jour. Aruel. Siat. Sci., Philudelphie, Vol. VIII.,

Platynstoma rentriensu (Hall). Pul. .V. Y., Tol. III., p. 300, Pl. LV., and p. 469, Pls. CXII., CXIII. and CXV.

"Shell globose, or depressed crlobose, and often obliquely ovoid, varying in form. Spire moderately elevated, consisting of three or four volutions, the last of which is extremely ventricose: volutions flattened upon the upper side; aperture circular or subovate; columellar lip reflexed. Surface marked by fine closely arranged stria parallel to the lines of growth." (Hall, loc. cit., p. 469.)

Casts apparently belonging to this species are far from uncommon in the Corniferous Limestone of Ontario, and I have figured one of the best that I have seen (Plate II., fig. 4). In form and dimensions the specimens differ considerably, but they all agree in the moderately elevated spire, ventricose body-whorl, and simply striated surface. The specimen figured has the body whorl less convex bolow than is usual in this species as figured by Hall, and its dimensions are as follows:- Height one inch and a half in reality somewhat over this); breadth two inches and two lines; height of aperture, sixteen lines; width of aperture, seventeen lines. Many of the examples, however, have dimensions smaller than the above.

Locality and Formation.-Corniferous Limestone, Port Colborne.

\section{Genus Strophostrlus (Hall).}

Shell with a depressed or moderately elevated spire, and an expanded and ventricose 
body-whorl, which does not become free at the aperture. A distinct columella is present, and this has a peculiar twisted form or is spirally grooved. No umbilicus. Outer lip thin.

The typical species of Strophostylus are recognised by their thin shell, commonly expanded round or oval aperture, surface with simply concentric lines, and twisted columella. The last character, however, is one which is very rarely available, and it may, therefore, be left out of consideration. The surface ornamentation is likewise not constant, for whilst consisting in the typical species of transverse striæ alone, Hall has described species with longitudinal or revolving striæ in addition, and the Stropliostylus? cancellatus of Meek and Wor then has a regularly cancellated surface. In these cases, the shell comes closely to resemble Cyclonema and some species of Holopea, and, if the columella can not be observed, the determination must rest upon the general form of the shell, which has a depressed or slightly elevated spire and a greatly expanded body-whorl and aperture in Strophostylus, whereas in the two last-mentioned genera the shell is more elevated and turbinate and the body-whorl is only moderately large. It is quite possible that these differences may often prove deceptive, but in the numerous fossil Gasteropods in which the mouth can not be observed, it is difficult to point to any other characters by which a generic determination may be effected.

In the Corniferous Limestone of Ontario occur two or three species of Gasteropods which have the general form of Strophostylus with the cancellated surface of Cyclonema or Holopea (in part). The true affinities of these, owing to their imperfect preservation, can not be made out; but, in accordance with the considerations above brought forward, I shall in the meanwhile refer them provisionally to Strophostylus. I have not been able to identify any of these with previously-recorded species, and have, therefore, $b$ en compelled reluctantly to describe them as new. As many of the descriptions of the known species are, however, very incomplete, it is quite possible that they are not really new.

\section{Strophostylus? SUB-GLoBosus (Nicholson).}

(Plate II., Fig. 3).

Shell globose, thick, with a depressed spire which is hardly elevated above the upper surface of the body-whorl, except close to the aperture. Volutions three, very rapidly increasing in size, convex, the body-whorl enormously expanded and somewhat flattened on its upper surface. Height one-third less than the width. Sutures not canaliculated, and hardly marked at all except between the body-whorl and the spire near the aperture. Aperture large, nearly circular, the outer lip meeting the volution above at considerably less than a right angle, and not extending any further forward than the margin of the aperture below. Outer lip apparently not reflected; inner lip callous; apparently no umbilicus. Surface with numerous revolving thread-like strix, of which five occupy the space of one line, and which are crossed by elevated thread-like transverse striæ, which are directed obliquely backwards, and of which about three occupy the space of one line, thus giving rise to a system of oblong cancelli.

Height of specimen fourteen lines; width, twenty-two lines; height of aperture, thirteen lines; width of aperture, thirteen lines.

From S. globosus (Hall), the present species is separated by its larger dimensions, its noncanaliculated suture, and its much more distinct cancellation. From Strophostylus? cancellatus of Meek and Worthen, it is separated by the fact that the outer lip does not meet the volution above at a right angle, and is not prolonged further forward than the lower margin of aperture. whilst the shell appears to be much larger and more globose, and the cancellation is more distinct and pronounced.

Locality and Formation.-Corniferous Limestone, Port Colborne.

\section{Strophostylus? ovatus (Nicholson).}

(Plate II., Fig. 10).

Shell transversely elongated or ovoid, the height being to the width as three to five. Spire small, moderately elevated; volutions three, regularly convex; the sutures apparently linear, and not canaliculated; the body-whorl ventricose and especially dilated near the 
aperture. The aperture transversely oval, sub-elliptical ; the outer lip not reflected, and meeting the volution above nearly at right angles, but not prolonged further forward than the lower margin of the aperture. No umbilicus. Surface cancellated with numerous revolving and transverse thread-like strix, the former about seven and the latter three or four in the space of one line. Between the concentric striæ are numerous finer strix, having the same direction, but so delicate that they can only be detected by the use of a high magnifying power. On the columellar side of the aperture the transverse stria radiate from a point, the revolving stria running nearly parallel with the inner lip, and the cancelli are nearly square, whereas elsewhere they are oblong. The transverse stria have a most peculiar and characteristic curvature; springing from the suture above, they are directed obliquely backwards with a dorsal concavity; they then make a great curve of which the convexity is directed dorsally, and which is situated on the lateral aspect of the whorl, and then finally they are again curved in the opposite direction, so that their convexities are directed towards the aperture. Whether the form of the outer lip conforms to this curvature of the concentric stria has not been determined.

Height of specimen, twelve lines; breadth, twenty lines. Height of aperture ten lines; width of aperture, fourteen lines.

This species, whether rightly referred to Strophostylus or not, appears to be distinguishable by its peculiar form and the characters of its surface-ornamentation.

Locality and Formation.-Corniferous Limestone of Port Colborne.

\section{Strophostylus obliquUs (Nicholson).}

(Plate II., Figs. 11, 11 $\iota$ ).

Shell obliquely elliptical, its height being to its width nearly as one to three. Spire small, slightly elevated; volutions three or four, rapidly increasing in diameter; the bodywhorl greatly expanded. The volutions of the spire are simply rounded and convex, but the body-whorl is obliquely flattened above, so that its upper surface joins the rolution above, almost at an angle of 180 . Sutures obscurely canaliculated. Tnder surface slightly hollowed out; a small umbilicus. A perture obliquely orate, slightly angulated above; its height. nearly double its width; the outer lip thin, the columellar lip unknown. Furfice cancellated with stroner revolving stria, aud much fuer aud more elosely-set transverse strix.

Height of specimen, about e'ght lines; width, eighteen lines; beight of aperture, fourteen lines; width of aperture, nine lines or less.

This species is distinguished from all other speeies of strmplentylus, both by its surface. characters and by its very yeculiar obliyuely-elongated form. It would seem to be somewhat allied to S. trunserisus (Hall), but as the columella is not known. its reference to struplustylus is rendered doubtful.

Locality and Formation.-Corniferous Limestone, Port Colborne.

\section{Genus Holopea (Hall).}

"Shell conical, ventricose, more or less oblique or nearly direct; aperture round-ovate ; margin entire; surfice marked by simple fine curved strix, or cancellated " (Hall, Pul. Tew" York, Vol. I., p. 169).

The limits of the genus Holopee can hardly be rigidly defined as far as our present knowledge goes. In general form Holopen is closely similar to Cyclonema, and the characteristic surface-ornamentation of the latter is sometimes present in the former. An umbilicus appears to be usually present in Holopea, and is universally absent in Cyclonema, but it is sometimes wanting in the former genus also. From strophustylus, the genus Holopece is distinguished by its more elevated spire, its turbinate form, and its less ventricose body-whorl and less expanded aperture.

The following species from the Corniferous Limestone of Ontario may be referred, at any ate provisionally, to the genus Holopea. 


\section{Holopea Eriensis (Nicholson).}

\section{(Plate II., Fig. 9).}

Shell turbinated, with a large ventricose body-whorl. Apical angle $90^{\circ}$. Volutions nearly four: spire small, elevated; all the whorls convex, and the body-whorl very strongly rounded, and ventricose. Sutures deep. Aperture broad ovate, or sub-circular; the outer lip bent inwards towards the base ; the peristome thick, and either "ntire or only confluent with the columella for a short distance. A minute umbilicus (?). Surface with no spiral band, but with revolving thread-like strix, about eight of them in the space of one line. No transverse striæ.

Height of specimen eight lines, of which the spire occupies less than two lines; width (including the aperture) ten lines. Height of aperture five lines; width the same.

This form is allied to Holopea Guelphensis and II. Gracia (Billings), but is a smaller form than either. I cannot identify it with any previously recorded form, and have therefore desoribed it as new.

\section{Locality and Formation.-Corniferous Limestone, Ridgeway.}

\section{Genus Helicotoma (Salter).}

The name Helicotoma was proposed by Salter for a group of shells which he believed to form a sub-genus of Scalites, and to be distinguished by their depressed discoid form, their nearly flat spire, the obtuse angulation of the whorls externally, their broad umbilicus, and their cirrhoid or helicoid form. In the typical species the umbilicus is wide, and the aperture is deeply notched above; but the latter feature does not appear to be constant. So far as is certainly known, the genus is exclusively Upper Cambrian and Lower Silurian.

It is with extreme doubt that I refer any Devonian shell to this genus, but the Corniferous Limestone has yielded casts of a shell which agrees in all respects with such a form of Heticotoma as $H$ eucharis (Billings), except in the snall size of the umbilicus, and which I can not at present refer to any other recognised genus. In the meanwhile, therefore, I shall describe the following species under Helicotome, though it is exceedingly probable that better examples will show that this is not its true generic position.

\section{Helicotoma serotina (Nicholson).}

(Plate II., Figs. 8, 8a).

Shell small, of three or four volutions, which increase gradually in size to the apercure. Spire depressed, almost perfectly fiat, the upper surface of the body-whorl lying on the same plane as the spire. Upper side of the body-whorl sloping slightly to the suture. All the whorls are angulated above, so that the shell slopes from the margin of the discoid upper surface all round to the centre of the base. Aperture large, sub-rhombic, the outer angle not notched (?), the inner angle prolonged much further inwards than the upper; umbilicus small, with steep sides, not exposing the whorls within.

Surface with numerous, close-set, rerolving strix, and exhibiting (in the cast) no traces of a spiral band.

Height six lines; width one inch; height of aperture six lines; from the inner to the outer angle eight lines; width five lines. Diameter of umbilicus one line.

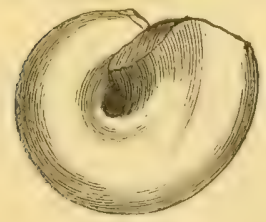

a

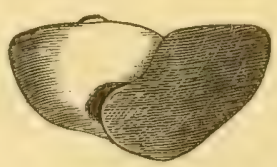

6

Fig. 53. Under surface of Helicotome? serotina (Nich.), showing the be that it is to the latter of these types that minute umbilicus; $b$. Front view of the same. From a natural it should be referred, since its umbilicus is
cast from the Cornifernus Limestone.

I have been greatly puzzled where to locate this singular fossil. But for the marked angularity of the whorls on their external and superior margin and the apparent complete absence of a band, I should certainly have considered the species as being a discoidal form of Pleurotomariu. As it is, the general form of the shell is singularly like that of Helicotoma or Raphistoma, and it may it should be referred, since its umbilicus is
very small. These, however, and all the 
other forms allied to Scalites, are essentially Primordial and Lower Silurian. The two or three specimens that I have seen are simply casts, with mere fragments if the actual shell adhering to them, and it must at present remain doulstul to what generic group they really belong. Locality and Formation.-Corniferous Limestone, Port Colborne.

\section{CHAPTER VI.}

\section{Annelida and Crustacea of the Corniferous and Hamilton Formations.}

\section{AnNelidi.}

The remains of Annclides, though far from uncommon in the Devonian Rocks of Ontario, are entirely referable, so far as I have seen, to the genera Spirorbis and Ortonia, though there are indications of the existence of genuine Serpule or Termilice. Of the two species of Spirorbis which have come under my notice, one is the $S$. omplaclodes of Goldfuss, a form which occurs in the Devonian of Europe, whilst the other I cannot identify at present with any recorded form. The genus Orloniu is apparently represented by one species, which appears to be new.

\section{Genus SpIRorbis (Daudin).}

Tube calcareous, solitary, coiled into a flat spiral, which may be dextral or sinistral, and which is attached by one flat surface to some foreign olject. The genus appears to have commenced its existence in the Silurian period, and is well represented by living species in existing seas.

\section{Spirorbis OMPHALOdes (Goldfuss).}

\section{Serpula omphalodes (Goldfuss), Petref. Germ. Pl. LXVII., Fig. 3.}

Tuhe dextral, of two and a half turns, the outer side of each turn being somewhat flattened, and the upper edge obtusely angulated or gently rounded. Diameter, when adult, about a line and a quarter, height about one-third if a line, the diameter of the slightly upturned mouth nearly half a line. The last turn of the tube is much the largest, and a wellmarked umbilicus is present, though the turns are contiguous. Surface smooth, and without ridges or tubercles of any kind.

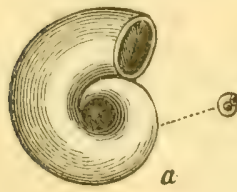

Fig. 54 .

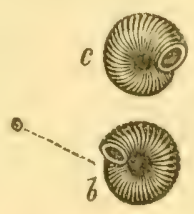

A Svirorbis omphatodes (Goluluss), natural size and enlarged; $b$ Spirorbis Arkonensis (Nich) of the natural size and enlarged; $c$ a dextral ex-
ample of the same, enlarired. From the Hamilton Formation.
There can be no hesitation in identifying this species with the European form, with which it agrees in its form, size, and proportions, and in the characters of the surface. It occurs in the Corniferous Limestone in the form of casts of the tube, adhering to the corallites of Diphyllum arundinaceum; and it is common in the Hamilton group, growing upon Heliophyllum Halli, Cystiphly7hm irsiculosum, C. Americenum, and occasionally Spivifera mucronata.

Locality aced Formution.-Corniferous Limestone, Lot 6, Con. 1, Wainfleet. Hamilton Formation, BartBosanquet, and Widder.

\section{Spirorbis Arkonensis (Nicholson).}

Tube minute, sinistral or dextral, of two turns, rounded, and somewhat globular owing to the elevation and large size of the last turn. Aperture circular, usually turned upwards. Diameter of the entire spiral about a third of a line, never exceeding half a line. Surface marked with numerous very clısely-set thread-like transverse annulations or ridges, which are not separated by more than their own width. A minute umbilicus is present. 
I cannot identify this pretty little form with any previously recorded. It presents the peculiarity that individuals in other respects precisely similar (Fig. 54 b,c) are sometimes dextral and at other times sinistral, the latter being the commonest upon the whole. The terminal portion of the tube is sometimes non-adherent and elevated above the surface, and the species is very readily rccognized by its minute size, and its surface-ornamentation. It appears to be quite distinct from $S$. angulatus (Hall), which, so far as I am aware, is the only species yet recorded from the Hamilton Formation. It occurs in great abundance attached to the exterior of species of Heliophyllum and Cystiphyllum, and also occasionally attached to Brachiopods.

Locality and Formation.-Hamilton Formation, Bartlett's Mills, near Arkona, Township of Bosanquet.

\section{Genus Ortonia (Nicholson).}

Animal solitary, inhabiting a calcareous tube, which is attached along the whole of one side to some foreign body. Tube slightly flexuous, conical, in section eylindrical, or somewhat flattened laterally and sub-triangular; surface marked with encircling ridges or annulations which may be confined to the lateral surfaces of the tube, or which pass completely round it.

The only recorded species of the genus are Ortonia conica (Nich.), O. minor (Nich.), and O. carbonaria (Young), the first two from the Lower Silurian, and the last from the Carboniferous Rocks. It is, therefore, interesting to find a species of the genus in the Devonian Rocks, thus occupying an intermediate position in point of time as regards the species already known.

\section{Ortonia intermedia (Nicholson).}

Tube conical, straight or flexuous, attached by the whole of one surface to some foreign body. Length, when fully grown, from a line and a half to two lines; diameter of the aperture somewhat less than a line. Surface marked with strong encircling, sometimes lamellose annulations or ridges, of which there are about eight or ten in the space of one line near the mouth, but more than twice the number in the same space towards the closed end of the tube. Sometimes, the annulations are extended into wing-like prolongations (Fig. 55b.) on the lateroinferior aspects of the fossil, and the tube is attached by means of these to the surface to which it is adberent; and in all eases they are more pronounced on the sides than on the aspect opposite to the surface of attachment.

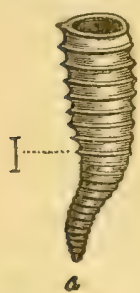

Fig. 55

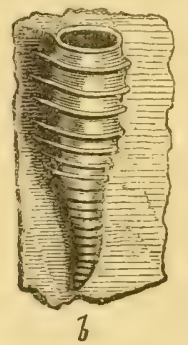

Ortonia intermedia (Nich.) a. Ore of the tubes enlarged; $b$. another example, in which the anmulations are greatly extended which the anmulations are greatly extended
laterally, enlarged. From the Hamilton Formation. form the annulations.

The species to which $O$. intermedia is most closely allied is 0 . minor (Nich.), but the tube is not so strongly bent towards its closed extremity; it is upon the whole a decidedly larger and more robust form ; and the annulations are considerably more remote and stronger.

0 . intermedia occurs attached to the exterior of various species of Cystiphyllum and Heliophyllum; and it is always strictly solitary, though three or four individuals often occur within a space of a few lines. 
Locality and formation.-Not uncommon in the Hamilton Formation, Bartlett's Mills, near Arkona, Township of Bosanquet.

\section{Crustacea.}

The remains of Crustacea are not uncommon in both the Corniferous Limestone and the Hamilton Formation of Western Ontario; but they are for the most part ill-preserved and fragmentary, and I have only been able to identify with certainty the well known species, Proetus crassimarginatus (Hall), Phacops rana (Green), Dalmanites Buothii (Green), and Leperditia (?) punctuliferc (Hall). Besides these, our collection includes fragments of some five or six additional species of Trilobites, which must be retained for further examination.

\section{Proetus crassimarginatus (Hall).}

Calymene crassimarginatus (Hall), Geol. Rep. Fourth Dist. New York, p. 172, fig. 5. Phillipsia (?) crussimurginatus; cited by Billings, Can. Journal, Vol. VI. p. 362.

Proetus crassimarginatus (Hall). Fifteenth Report on the State Cabinet, p. 100.

This familiar species is chiefly known by its pygidium, which is a common fossil in the Corniferous Limestone. The pycidium is somewhat wider than long, very convex, and margined by a thick concentrically-striated border, whence the specific name is derived. The axis is strongly convex and prominent, with thirteen or fourteen rings; and the lateral lobes are also very convex, and exhibit from twelve to thirteen ribs (Fig. 56). Along with the tails, occur sometimes exceedingly convex and prominent glabellx and also free cheeks, koth of which probably belong to this species.

Locality and Formation.-Corniferous Limestone, Ridgeway, Port Colborne, Lot 6, Con. 1 Wainfleet, and Hagersville.

\section{Dalmanites Boothit (Green).}

Cryphaus Boothii (Green), Silliman's Am. Jour. of Science, Vol. 32, p. 344.

Cryphcous calliteles (Green), Ibid., p. 346.

Dalmanites Boothii (Hall), Fifteenth Report on the State Cabinet, p. 91.

The tail of this pretty little species ifig. $56 \%$.), which is commonly known by the name of Dalmanites calliteles, is a by no means very rare fossil in the Hamilton Formation of Ontario. The pyegidium is semicircular, with a moderately prominent, tapering axis, which, when complete, exhibits from nine to twelve rings. The lateral lobes are depressed, and exhibit five or six pleurie, the extremities of which are prolonged beyond the margin in the form of so many obtusely-pointed processes or expansions which are gently curved backwards. Between the lateral groups of these processes, occupying the centre of the pygidium is a wider and shorter pointed process extending backwards from the rounded extremity of the axis. The entire surface is ornamented with minute papillæe or granules.

Locality aml Formution.-Hamilton group, Widder, and Bartlett's Mills, near Arkona, Township of Bosanquet.

\section{Phacops rana (Green).}

Calymene bufo, var rana (Green), Monograph, p. 42.

Phacops rana, (Hall), Fifteenth Report on the State Cabinet, p. 93.

This well-known species is chiefly represented by detached heads, though the pygidium is not of very uncommon occurrence, and the body-rings are occasionally seen. The cephalic shield (fig. 56u.) is nearly semicircular, and the posterior angles are slightly produced backwards. The glabella is very gibbous, but somewhat depressed on the upper surface; about one-third wider than long; the lobes obscurely marked out; the neck-furrow narrow but welldefined; and the neck-segment wide and conspicuous. The eyes are large and prominent, rising nearly as high as the top of the glabella, with large lenses. The thorax is one third longer than the head, its sides nearly straight, and its axis about as wide as the lateral lobes, or nearly so. The pygidium is twice as wide as long, or wider, regularly rounded behind, 


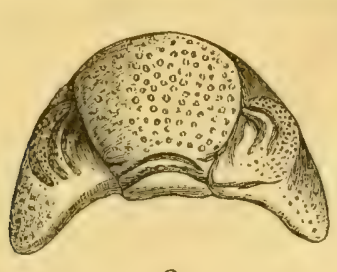

$a$

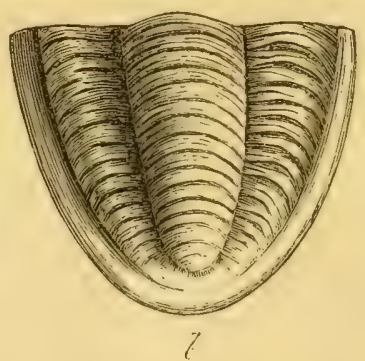

Fig. 56.

a. Phacops rana Green, (head shield); b. Pygidium of Proetus crassimarginatus (Hall); c. Pygidium of Dalmanites Boothit (Green).

with from eight to ten segments. The entire surface is covered with rounded granules, which are of larger size on the anterior labe of the glabella than elsewhere. Bosanquet.

Locality and Formation.-Hamilton Formation, Widder, and near Arkona, Township of

\section{Cythere? punctulifera (Hall).}

Beyrichia punctulifera (Hall), Fifteenth Report on the State Cabinet, p. 111.

"Carapace valves minute, semi-oval, almost equilateral, the anterior end very slightly narrower, convex and abruptly bending downwards to the dorsal margin ; marginal rim welldeveloped, and sharply elevated on the ventral and lateral margins. The surface at the more prominent part above the centre, and just at the bending downwards towards the dorsal margin, is marked by two very prominent nodes, which are nearly equi-distant from the margins and from each other. The entire surface is punctate with minute rounded pits." (Hall, Loc. cit).

Hall states that this is the most abundant of the Ostracoda of the Hamilton group, and I can hardly doubt that it is identical with a pretty little carapace, which is of very common occurrence in the Hamilton shales of Bosanquet, and which has the same punctated surface and marginal rim. If this be the case, however, the species can hardly be referred to Beyriclia, and our specimens differ in some important respects from Prof. Hall's description. The form is not semi-oval, but somewhat elliptical, with a long diameter of about one line and a short diameter of half a line, and having the posterior extremity markedly broader than the anterior. The dorsal margins are rounded, not straight, and the nodes alluded to by Hall are very obscure.* The surface, on the other hand, is covered entirely with exceedingly minute pits. On looking at the surface-characters of this species, one can hardly help speculating as to whether it may not have been the larval form of a Trilobite, like Dalmanites Boothi or Phacops rana, though the nature of ornamentation is far from being precisely the same.

Locality and Formation.-Common in the Hamilton Formation, Widder, Township of Bosanquet.

\section{CHAPTER, VII.}

\section{APPENDIX.}

\section{Aulopora (?) Canadensis (Nicholson).}

Alecto (?) Canadensis (Nicholson), Canadian Naturalist, Vol. 7, No. 3.

I originally described this fossil from casts obtained from the Corniferous Limestone, and I referred it with doubt to the Polyzoan genus Alecto, giving the following description of it:-

* On looking at the specimens of this species from the Hamilton Shales of Canandaigua, I find some to exhibit well marked nodes, whilst others, which in other respects appear to be precisely the same, agree with our Canadian exampleg in being either destitute of nodes or exhibiting them very obscurely. 
"Polyzoary adnate, attached parasitically to the exterior of corals, branching in an irregularly dichotomous manner. Cells in reality uniserial, but so disposed by the turning of each cell-mouth to alternate sides as to look as if bi-serial. The terminal portion of each cell bent outwards; the aperture circular. The cells tubular, elongated, slightly or not at all expanded and not at all elevated towards their apertures. Five cells in the space of two lines : width of cell about one-fiftieth of an inch near the mouth.

"I have considerable doubts as to the affinities of this extraordinary little fossil ; but I think it is certainly one of the Cyclostomatous Polyzoa, and I see at present no better course than to refer it to Alecto, Lamoroux. When not examined closely, the fossil presents a striking resemblance to a Sertularian Zoophyte, exhibiting exactly the appearance of a number of tubular calycles or cells springing alternately from the two sides of a common canal or stem. When minutely looked into, however, it is seen that this is deceptive, and that the fossil consists really of an alternate or sub-alternate series of long, tubular, slichtly flexuous cellules, each cell being nearly cylindrical, and having the terminal portion geniculated or bent outwards, in such a manner that the mouths of successive cells point in opposite directions.

"The difficulty in determining the systematic place of this fossil is much increased by the fuct that it occurs solely in the forms of casts, ramifying in the walls of moulds from which corals have been removed. It is, therefore, impossible to decermine what was the texture of the cœnœcium, whether calcareous or corneous; whilst the lines of division between the cells, where they come in contact with one another, are only very faintly and obscurely indicated. The form of the aperture of the cell appears to have been circular, and its position terminal ; but some uncertainty attaches to both of these statements."

Since writing the above, I have obtained specimens of the same fossil from the Hamilton group, in which the actual corallum itself is preserved, and these seem to show that the species is truly referrible to Aulopera, though certainly unlike the typical species of the genus.
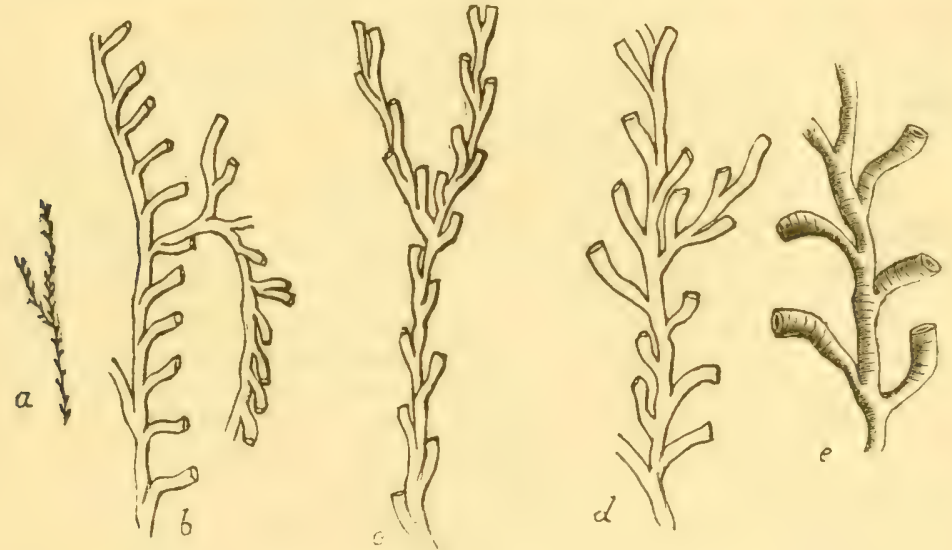

Fig. 57.

A ulopora (?) Canadensis (Nich.); $a$. A fragment natural size; b. Cast from the Corniferous Limestone, in which uniserial arrangement obtains, enlarged; $c$. Cast from the Corniferous Limestone, in which a biserial arrangement obtains d. A portion of the actual coral, from the Hamiltor group, enlarged; $e$. A fragment of the last still further enlarged.

The examples from the Hamilton group have the form of branching calcareous corals which are adherent by the whole of one surface to some foreign body. 'T'he tubes are semicylindrical or sub.cylindrical, marked with extremely fine encircling striæ, and having a diameter of about one fiftieth of an inch. The lateral tubes are produced from the sides of the main tube, usually alternately on opposite sides. and generally at intervals of from a third of a line to half a line. Their length varies from half a line to a line and a half, and their direction may be nearly parallel with the main tube, or at right angles to it, but generally forming angles of about $40^{\circ}$ to $50 .^{\circ}$ The apertures of the lateral tubes are not elevated above the general surface, and usually have an elliptical form.

I do not yet feel satisfied that this singular fossil is an Aulopora, though the well-preserved specimens from the Hamilton group secms to prove it not to be an Alecto. A main 
tube is certainly present, and the lateral tubes spring from it, and not from one another, as I was at first led to believe by my examination of casts from the Corniferous. The arrangement of the lateral tubes also is more variable than I had imagined. Sometimes they are entirely produced from one side of the tube (Fig. $57 \mathrm{~b}$ ) ; but at other times they are biserial and alternate regularly with one another (Fig. $57 \mathrm{c}$ ). The fossil differs from the typical species of $A$ ulo. pora in the great proportionate length of the lateral buds, and in their regular and more or less symmetrical method of growth, and more especially in the fact that the apertures of the tubes open in the plane of growth of the entire corallum, and are neither elevated above the general surface, nor perceptibly expanded.

The only species of Aulopora to which it has any affinity is A. filiformis (Billings), but this is a much more robust species, with larger tubes, and much more irregular method of growth, and apertures generally distinctly elevated above the general surface.

As occurring in the Corniferous Limestone, Aulopora (?) Canadensis is found chiefly growing on the epitheca of Fistulipora Canadensis, and Diphyphyllum arundinaceum. In the Hamilton Formation, it affects chiefly Heliophyllum Halli and Cystiphyllum vesiculosum, and in both groups it is commonly accompanied by Spirorbis omphalodes.

Locality and Formation.-Corniferous Limestone, Port Colborne, and Lot 6, Concession 1, Wainfleet. Hamilton Formation, Bartlett's Mills, near Arkona, Township of Bosanquet.

\section{Syringopora intermedia (Nicholson).}

Corallum lax, spreading, increasing by the production of lateral buds. Corallites cylindrical, often more or less crooked, having a diameter of from one line to a line and a half, or rarely two lines, the lateral buds being produced at angles of from $90^{\circ}$ to $40{ }^{\circ}$ and at intervals of from two to four lines. No connecting horizontal processes between the corallites, but sometimes abortive spines or nodes. Epitheca with fine encircling strix, and irregular growthswellings and geniculations. Internal structure, of infundibuliform tabulæ.

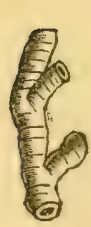

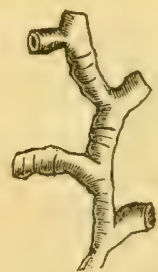

Fig. 58.

In its form and mode of growth, this form agrees altogether with Syringopora nobilis (Billings), of which I at first believed it to be simply the young. The latter, however, is a much larger form, its corallites having an average diameter of three lines, and sometimes as much as five lines, and its buds being produced at longer intervals. $S$. intermedia, on the other hand, occurs in the Hamilton formation ( $S$. nobilis being a Corniferous species), and though it is very abundant, I have never seen any example with a diameter exceeding two lines, the majority of specimens having a diameter of little over one line. The corallites also are much more crooked and irregular, and the branches are produced at much shorter intervals. Some speciFragrments of Syringopora inter- the
nedia (Nich.) natural size. From mens do not exhibit the internal structure, and these present a the Hamilton group.

resemblance to Aulopora cornuta (Billings), from. which, however, they are readily distinguished by not being creeping or parasitic. Upon the whole, S. intermedia appears to me to be distinguished by characters of specific value.

Locality and Formation.-Common in the Hamilton Formation, Widder ; and Bartlett's Mills, near Arkona, Township of Bosanquet.

\section{9. Аibocelia umbonata (Conrad).}

Orthis umbonata (Conrad), Journ. Acad. Nat. Science, Philadelphia, Vol. VIII., p. 264, Pl. XIV., Fig. 21.

Ambocalia umbonata (Hall), Thirteenth Report on the State Cabinet, p. 71.

Orthis nucleus (Hall), Geol. Rep. Fourth Dist., New York, p. 180.

Ambocolia umbonata (Hall), Pal. N. Y., Vol IV., p. 269, Pl. XLIV., Figs. 7-18.

Since the portion of this Report treating of the Bruchiopoda was written, I have come across two or three unmistakable examples of the ventral valve of this little shell, which if not identical with Spirifere Urii (Fleming), $[=P$. unguiculus, Phillips $]$, is certainly very close to it. Our specimens are from the Corniferous Limestone, a formation in which they do not appear to have been detected by $\mathrm{Hall}$, and I am chiefly concerned to notice their occurrence for the purpose of repeating that they are entirely distinct from Productella Ei iensis (Nich.), to which 
the ventral valve has a superficial resemblance. The ventral valve of $A$. umbonata is readily recognized by its very gibbous form, its extremely elevated and incurved beak, its possession of a distinct mesial sinus extending from the beak to the front margin, and the existence of a high and conspicuous area with a well marked fissure.

Locality and Formation.-Corniferous Limestone, Port Colborne.

160. Crania crenistriata (Hall).

Crania crenistriata (Hall), Thirteenth Report on the State Cabinet, p. 78.

Crania crenistriata (Hall), Pal. N. Y., Vol. IV, p. 28, Pl. III, figs. 13-16.

On examining the surface of some of the Heliophylla of the Hamilton group, to which во many small organisms are attached, I find several specimens of Crania crenistriata (Hall). The dorsal valve of this species is all with which I am acquainted, and it is depressed-conical, nearly circular, with a central or sub-central apex. The apex is smooth, and the remainder of the shell is covered by sharp elevated crenulate radiating striæ, which increase interstitially, and of which there are about ten in the space of one line at the margin. The diameter of an individual of medium size is two lines and a half the height of the valve being little over half a line.

The ventral valve has never been detected, and Hall has only seen four specimens of the dorsal valve ; but the species does not appear to be very rare in the Hamilton shales at Arkona.

Locality and Eormation.-Hamilton Formation, Bartletts' Mills, near Arkona, Township of Bosanquet.

\section{LIST OF FOSSILS FROM THE CORNIFEROUS AND HA- MILTON FORMATIONS OF WESTERN ONTARIO.}

(The letters C. and H. indicate the occurrence of the fossil in the Corniferous Limestone or Hamilton Formation.)

\section{ProtozoA.}

1. Astræospongia Hamiltonensis, Meek and Worthen ? (C).

2. Stromatopora tuberculata, Nicholson (C).

3. " " perforata, Nicholson (C).

4. " " granulata, Nicholson (C and $\mathrm{H})$.

5. " manmillata, Nicholson (C).

6. " concentrica, Goldfuss? (C).

\section{Ceelenterata.}

7. Blothrophyllum decorticatum, Billings, (C).

8. " approximatum, Nicholson (C).

9. Clisiophyllum Oneidaense, Billings (C).

10. " pluriradiale, Nicholson (C).

11. Zaphrentis gigantea, Le Sueur (C).

12. " fenestrata, Nicholson (C).

13. " $"$ prolifica, Billings (C).

14. " spatiosa, Billings (C). 
15. Heliophyllum Canadense, Billings (C).

16.

17.4

Colbornense, Nicholsmn (C).

18.

Cayugaense, Billings (C).

$19 . \quad$ " "

20.

21. 66

$22 . \quad$ "

$23 . \quad$ " exiguum, Billings ( $\mathrm{U}$ and $\mathrm{H}$ ).

24. Petraia Logani, Nicholson (C).

25. Amplexus Yandelli, Edw. and Haime (C).

26. Diphyphyllum arundinaceum, Billings (C).

27. " stramineum, Billings (C).

28. " gracile, McCoy (C).

29. Eridophyllum Simcoense, Billings (C).

30. " Verneuilanum, Billings (C).

31. Cystiphyllum Senecaense, Billings (C).

32. " grande, Billings (C).

33. " Americanum, Edw. and Haime (C and $\mathbf{H})$.

34. " " vesiculosum, Goldfuss (C and $\mathrm{H}$ ).

35. " sulcatum, Billings (C).

36. Microcyclus discus, Meek and Worthen $(\mathrm{H})$.

37. Haimeophyllum ordinatum, Billings (C).

38. Syringopora nobilis, Billings (C).

39. "Hisingeri, Billings (C).

40. " " perelegans, Billings (C).

41. " Maclurei, Billings (C).

42. " laxata, Billings (C).

43. Aulopora filifornis, Billings ( $\mathrm{C}$ and $\mathrm{H})$.

44. " cornuta, Billings $(\mathrm{C}$ and $\mathrm{H})$.

45. " tubæformis, Goldfuss (C).

46. " umbellifera, Billings (C).

47. Favosites Gothlandica, Lamarck, (C and H).

48. " basaltica, Goldfuss? (C).

49. " Forbesi, Edw. and Haime (C).

50. " hemispherica, Yandell and Shumard (C and H).

51. " turbinata, Billings ( $\mathrm{C}^{*}$ and $\left.\mathrm{H}\right)$.

52. " polymorpha, Goldfuss (C and $\mathrm{H})$.

53. " reticulata, De Blainville (C and $\mathrm{H})$.

54. " dubia, De Blainville (C).

55. " " cervicornis, De Blainville (C).

56. " Chapmani, Nicholson (C).

57. Alvenlites labiosa, Billings (C).

58. " Roemeri, Billings ( $\mathrm{C}$ and $\mathrm{H})$.

59. " cryptodens, Billings (C).

60. " conferta, Nicholson (C).

61. " (Conites?) distans, Nicholson (C).

62. " ramulosit, Nicholson (C).

63. " Billingsi. Nicholson (C).

64. " "Selwynii, Nicholson (C).

65. " Goldfussi, Billings (H).

66. " " Fischeri, Billings ( $\mathrm{O}$ and $\mathrm{H})$.

67..$\quad$ frondosa, Nicholson (H).

68. Striatopora Linneana, Billings $(\mathrm{H})$.

69. 'Irachypora elegantula, Billinos $(\mathrm{H})$.

70. Chretetes moniliformis, Nicholson (H).

71. " Barrandi, Nicholson $(\mathrm{H})$.

72. " quadrangularis, Nicholson $(\mathrm{H})$. 
73. Callopora incrassata, Nicholson $(\mathrm{C}$ and $\mathrm{H})$.

74. Fistulipora Canadensis, Billings ( $\mathrm{C}^{\mathrm{y}}$ and $\mathrm{H}$ ).

75. Michelinia convexa, D'Orbigny (C).

\section{Brachiopoda:}

76. Strophomena perplana, Conrad (C).

77. " demissa, Conrad (C).

78. " 6 inequistriata, Conrad ( $\mathrm{C}$ and $\mathrm{H})$.

79. " Patersoni, Hall (C).

80. " " ampla, Hall (C).

81. " " nacrea, Hall (C).

82. " " rhomboidalis, Wahlenberg (C).

83. Streptorhynchus Pandora, Billings (C).

84. Orthis Livia, Billings (C).

85. " Vanuxemi, Hall $(\mathrm{H})$.

86. Chonetes lineata, Vanuxem (C and $\mathrm{H})$.

87. " scitula, Hall (H).

88. “ lepida, Hall (H).

89. " mucronata, Hall (C).

90. " " hemispherica, Hall (C).

91. " arcuata, Hall (C).

92. " acutiradiata, Hall (C).

93. Productella Eriensis, Nicholson (C).

94. Atrypa reticularis, Linnous ( $\mathrm{C}$ and $\mathrm{H})$.

95. “ spinosa, Hall (C).

96. Spirifera mucronata, Conrad ( $\mathrm{C}$ and $\mathrm{H}$ ).

97. " varicosa, $\operatorname{Hall}(\mathrm{C})$.

98. " duodenaria, Hall (C).

99. " raricosta, Conrad (C).

100. " fimbriata, Conrad (C).

101. Cyrtina Hamiltonensis, Hall (H).

102. Spirigera spiriferoides, Eaton ( $\mathrm{C}$ and $\mathrm{H})$.

103. " rostrata, Hall $(\mathrm{H})$.

104. " scitula, Hall (C).

105. Attyris nasuta, Conrad (C).

106. " (?) Maia, Billings (C).

107. Retzia (?) Eugenia, Billings (C).

108. Leiorhynchus multicosta, Hall (H).

109. “ Huronensis, Nicholson (H).

110. Amphigenia elongata, Vanuxem (C).

111. Lingula squamiformis, Phillips ?(C).

112.4 Maida, Hall? (C).

113. Pholidops ovatus, Hall (C).

114. Cœlospira concava, Hall (C).

115. Centronella glans-fagea, Hall (C).

116. "Hecate, Billings (C).

\section{PoLYZOA.}

117. Botryllopora socialis, Nicholson (H).

118. Ceriopora (?) Hamiltonensis, Nicholson (H).

119. Ptilodictya Meeki, Nicholson (C and $\mathrm{H})$.

120. Polypora pulchella, Nicholson (C).

121. "Halliana, Prout (C).

122. " tenella, Nicholson (C).

123. " tuberculata, Nicholson (H).

124. Retepora prisca, Goldfuss (C and H). 
125. " Phillipsi, Nicholson (C).

126. Cryptopora mirabilis, Nicholson (C).

127. Fenestella magnifica, Nicholson (C):

128. " marginalis, Nicholson (C).

129. " cribrosa, Hall (H).

130. " tenuiceps, Hall $(\mathrm{C}$ and $\mathrm{H})$.

131. " filiformis, Nicholson (C).

132. Tæniopora exigua, Nicholson (H).

133. " penniformis, Nicholson $(\mathrm{H})$.

134. Carinopora Hindei, Nicholson (C).

135. Clathropora intertexta, Nicholson (C).

\section{LAMELLIBRANOHIATA.}

136. Conocardium trigonale, Hall (C).

\section{Pteropoda.}

137. Tentaculites sp. (H).

\section{Gasteropoda}

138. Platyceras ventricosum, Conrad (C)

139. " intermedium, Hall (C).

140. " "sp. (C).

141. " sp. (C).

142. " uniseriale, Nicholson (C).

143. " dumosum, var. rarispinum, Hall (H).

144. Platyostoma ventricosa, Conrad (C).

145. Strophostylus ? sub-globosus, Nicholson (C)

146. " ? ovatus, Nicholson (C).

147. " ? obliquus, Nicholson (C).

148. Holopea Eriensis, Nicholson (C).

149. Helicotoma? serotina, Nicholson (C).

\section{Annelid A.}

150. Spirorbis omphalodes, Goldfuss (C and $\mathrm{H}$ ).

151. " Arkonensis, Nicholson (H).

152. Ortonia intermedia, Nicholson (H).

\section{Crustacea}

153. Proetus crassimarginatus, Hall (C).

154. Dalmanites Boothii, Green (H).

155. Phacops rana, Green $(\mathrm{H})$.

156. Cythere? punctulifera, Hall $(\mathrm{H})$.

\section{APPENDIX}

157. Aulopora? Canadensis, Nicholson (C and $\mathrm{H})$.

158. Syringopora intermedia, Nicholson (H).

159. Ambocolia umbonata, Hall (C).

160. Crania crenistriata, Hall $(\mathrm{H})$. 


\section{INDEX.}

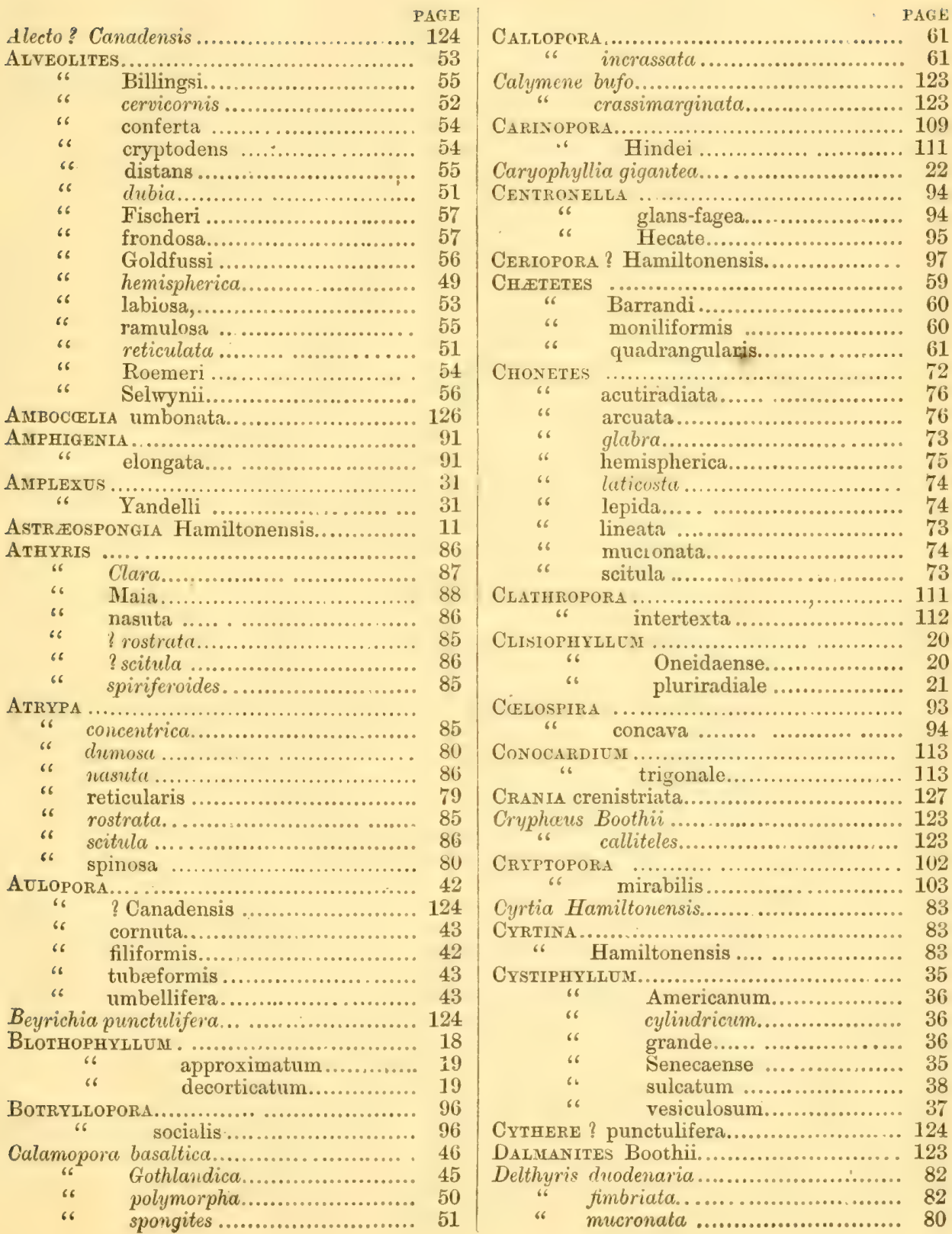


Delphyrus raricosta........................ 82

undulata

DIPHYРНХLLUM, .......................... 31

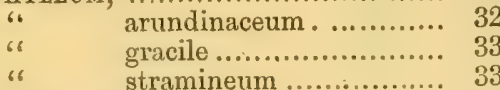

Emmonsia hemispherica..................... 49

ERIDOPHYLLUM ............................. 34 66

Simcoense.

Verneuilanum

Favosites.

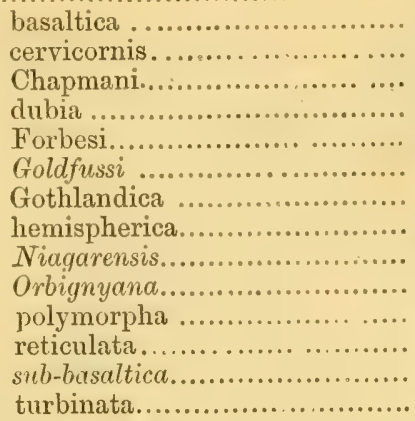

Fenestella. 100

filiformis.................... 107

magnifica ...................... 104

marginalis ....................105

tenuiceps ...................... 106

Fistulipora............................... 63

66 Canadensis .....................

HAIMEOPHYLLUM,

ordinatum..............

Heliophyllum

\begin{tabular}{|c|c|}
\hline 66 & Canadense ....... \\
\hline 66 & Cayugaense ................ \\
\hline "6 & Colbornense ............... \\
\hline 66 & colligatum ............. \\
\hline 66 & Eriense ............... \\
\hline 6 & exiguum ........... \\
\hline 66 & Halli................ \\
\hline 6 & proliferum ....... \\
\hline & sub-cæespitosum........ \\
\hline
\end{tabular}

HoLOPEA ............................... 119

Eriensis .......................... 120

66 Huronensis................ 90

Leptocoelia concava.

multicosta

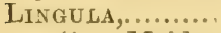

Maida............................. 93

squamiformis...................... 92

Meganteris elongatus............................ 91

Meristella elissa................................ 86

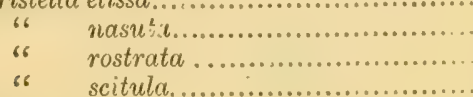

Michelin IA ................................ 63

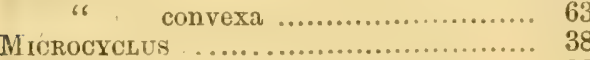

discus....................... 38

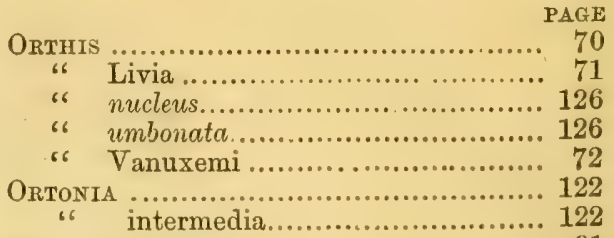

Pentamerus elongatus......................... 91

Petraia Logani............................... 30

Phacops rana............................... 123

Phillipsia? crassimarginata................ 123

Pholidops ovatus. . ............................ 93

Platyceras .................................. 115

dumosum, var. rarispinum. 116 intermedium (?)............. 115

sp........................... $\mathbf{1 1 6}$

sp........................ 116

uniseriale ................... 116

.6 $\quad$ ventricosum ................. 115

Platyostoma ................................ 117

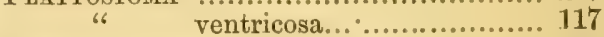

Pleurorhynchus trigonalis.................... 113

Polypora .................................... 98

"6 Halliana ......................... 99

، pulchella......................... 99

"6 tenella........................... 100

6 tuberculata......................... 100

Productella ................................ 76

" "Eriensis................... 77

Proetus crassimarginatus................... 125

Ptilodicty................................... 97

“6 Meeki......................... 97

Rensselaeria elongata ........................ 91

Retepora ................................... 101

66 Phillipsi ........................... 102

prisca........................ 101

Retzia .................................. 89

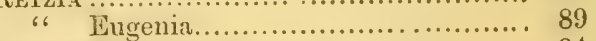

Rhynchonella glans-fagea..................... 94

? Laura...................... 89

Serpula omphalodes........................... 121

SPIRIFEra................................. 80

"6 duodenaria......................... 82

"6 fimbriata ...................... 82

"6 mucronata....................... 80

6 $\quad$ raricosta ........................ 82

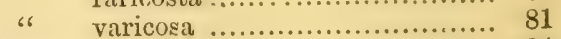

SPIRIGERA.............................. 84

${ }_{66}$ concentrica........................ 85

"6 rostrata.......................... 85

" scitula............................ 86

Spirigerina reticuleris....................... 79

S'rREPTORHYNCHUS......................... 69

Pandora.................. 70

STRIATOPORA............................ 58

Linneana .................... 59

Stricklandinia elongata........................ 91

STROMATORORA.............................. 11

${ }_{66}$ concentrica .................. 17

66 granulata................... 16

6 mammillata ......,........... 17

" $\quad$ perforata...................... 15

، $\quad$ tuberculata.................... 14

Strombodes helianthoides ...................... 26

Strophodomta rm.? 
Strophodonta demissa

PAGE

65 Strophomena rhomboidalis.

PAGE

"6 inequistriata..................

66

6 nacrea 68

6" perplana .................... 64

STROPFOMENA.

64

acutivadiate ............... 76

ampla....................... 67

crenistria................. 64

delthyris .................. 64

demissa.................... 65

fragilis ...................... 64

inequistriata ............... 66

lepida....................... 74

linecte ........................ 73

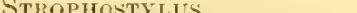

6 (?) obliquus................. 119

"6 (!) ovatus.................. 118

"6 (?) sub-globosus ... ..... 118

SYRIN(O)PORA .

"6 Hisingeri.................. 40

6 intermedia .................. 126

$66 \quad$ laxata 41

" Maclurei ... ............... 41

" nobilis .................. 40

.. perelegans..... .............. 41

6 tubiporoides ................ 41

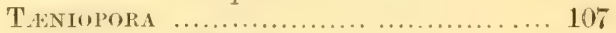

meronata................ $74 \quad$ exigna .................... 108

nacrea .................... 68 penmiformis ............. 10!

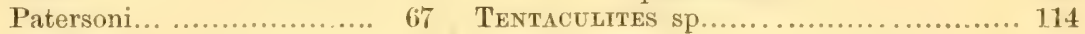

perplana .................. 64 Trachypora.......................

plaristriata ................. $64 \quad$ 66 elegantula.................. 59 




\section{PLATE I.}

Fig. 1. Stromatopora ostiolata, Nich. A fragment of the natural size, from the Guelph Formation. Introduced for comparison.

1a. Portion of the same, enlarged, showing the oscula on the surface.

Fig. 2. Stromatopora tuberculata, Nich. A fragment of the natural size. (p. 14.) $2 a$. Section of a portion of the same, enlarged.

Fig. 3. Stromatopora granulata, Nich. A fragment of the natural size. (p. 16.)

$3 a$. Section of a portion of the same, enlarged.

Fig. 4. Stromatopora mammlata, Nich. A fragment of the natural size. (p. 17.) 
Plate.l.

PALAEONTOLOGY OF ONTARIO.
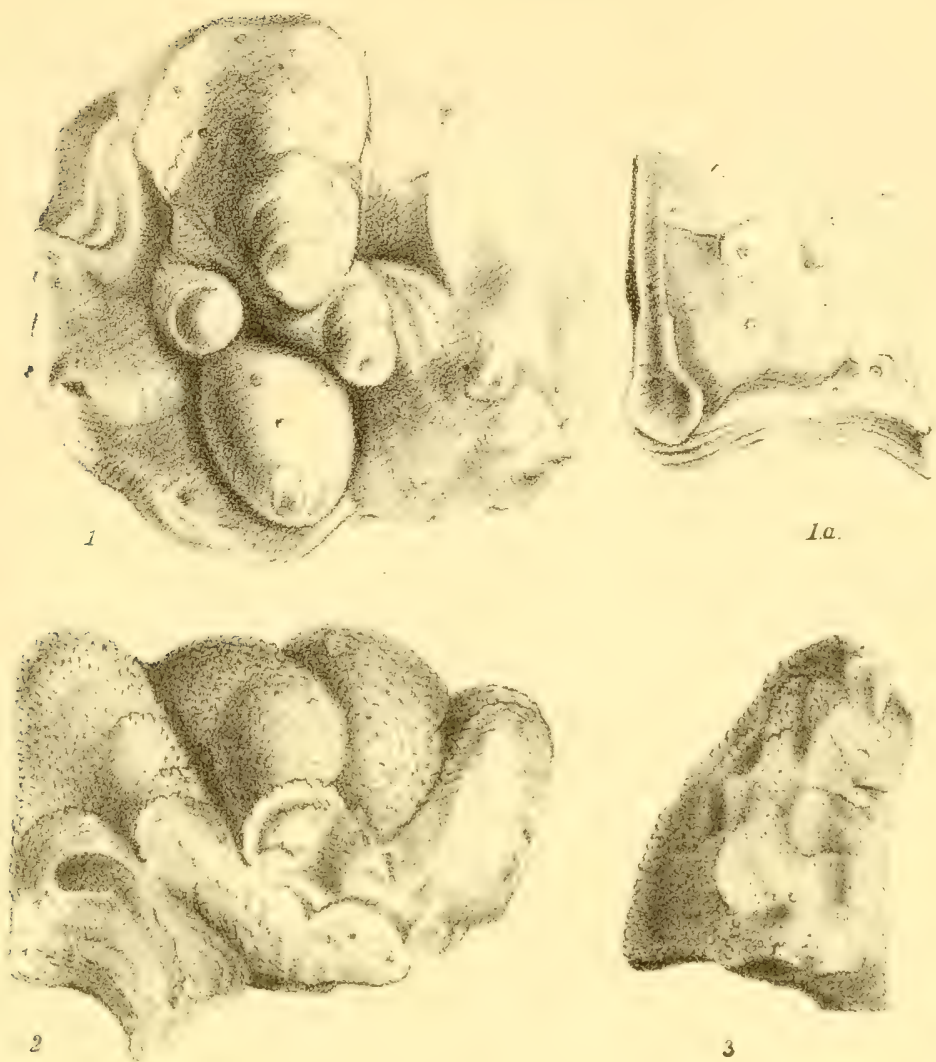

3
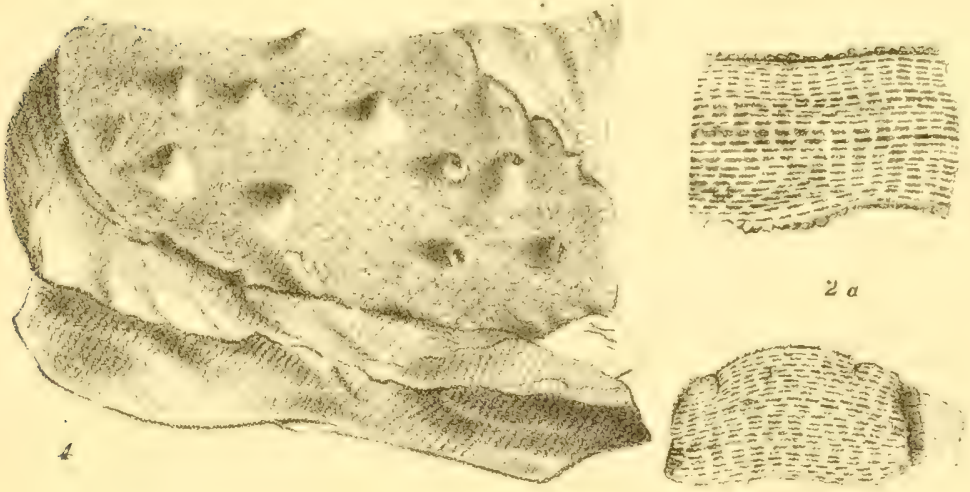

¿゙ a

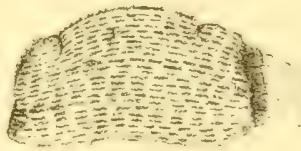

$3 a$

"IC Hutchison del ad nat. 




\section{PLATE II.}

Fig. 1. Platyceras ventricosum, Conrad. Viewed from above. Nat. sizo. (p. 115.) 1a. Portion of the surface, enlarged.

Fig. 2. Platyceras intermedum, Hall (?). Nat. size. (p. 115.)

Fig. 3. Strophostylus (?) sub-globosus, Nich. Nat. size. (p. 118.)

$3 a$. Portion of the surface of the same, enlarged.

Fig. 4. Platyostoma ventricosa, Conrad. Nat. size. (p. 117.)

Fig. 5. Platyceras uniseriale, Nich. Nat. size. (p. 116.)

Fig. 6. Platyceras sp. - Nat. size. (p. 116.)

Fig. 7. Platyceras sp. Nat. size. (p. 116.)

Fig. 8. Helicotoma (?) serotina, Nich. Nat. size. (p. 120.)

$8 a$. The same viewed from above.

Fig. 9. Helopea Eriensis, Nich. Nat. size. (p. 120.)

Fig. 10. Strophostrulus (?) ovatus, Nich. Nat. size. (p. 118.)

$10 a$. Portion of the surface of the same, enlarged.

Fig. 11. Strophostrlus (?) obliquus, Nich. Dorsal aspect, nat. size, (p. 119.)

11 . Front view of the same, nat. size. 
Plate.2. PALAEONTOLOGY OF ONTARIO.

$1=$

(111)
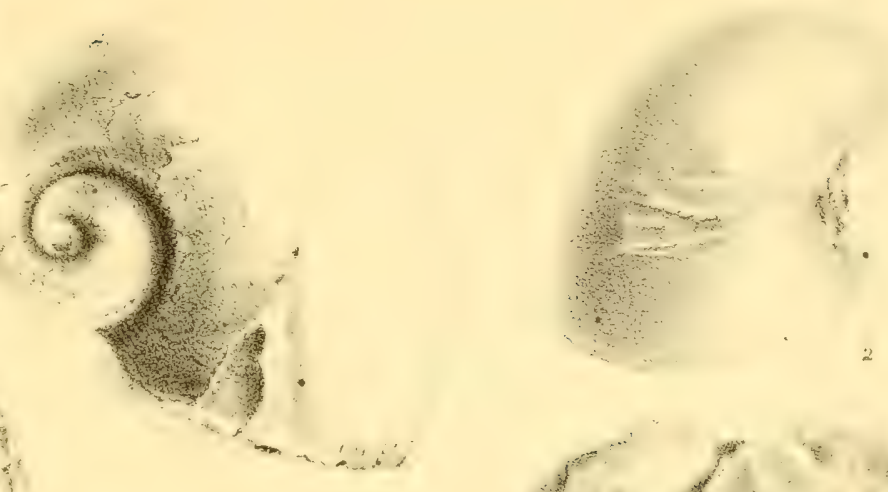

$3 a$
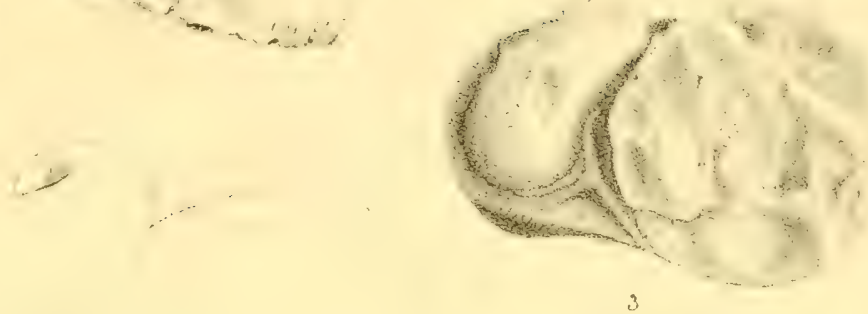

3

4
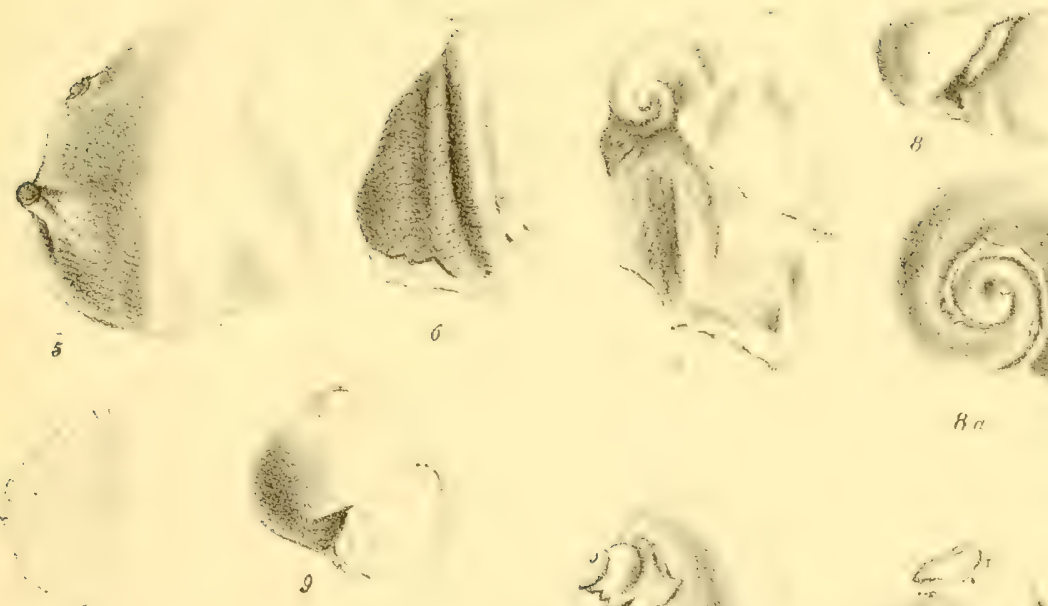

in $n$
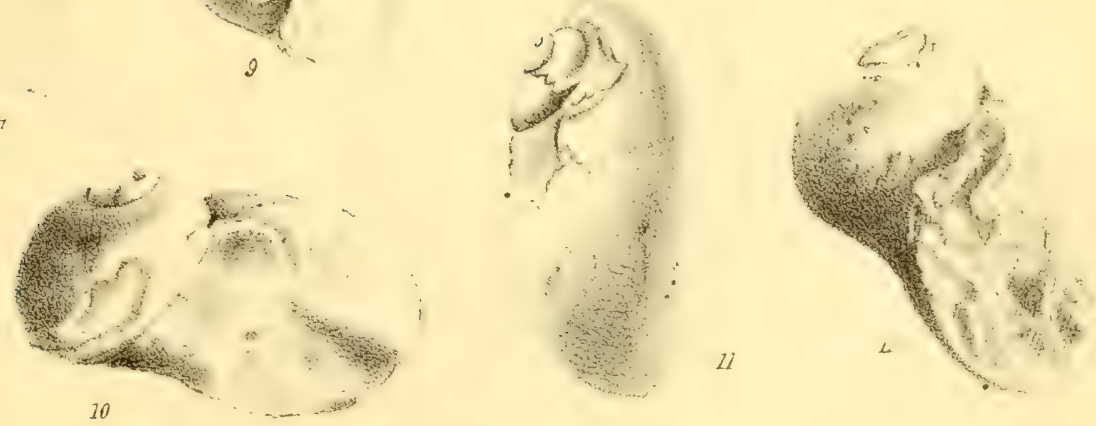




\section{PLATE III.}

Fig. 1. Zaphrentis gigantea, Lesueur. A specimen naturally split longitudinally Nat. size. (p. 22.)

Fig. 1 $a$. Another example of the same, of the natural size. Both of these figures represent immature individuals.

Fig. 2. Zaphrentis prolifica, Billings. Nat. size. (p. 23.)

-2a. Portion of the edge of the calice of the same, enlarged.

Fig. 3. Petraia (?) Logani, Nich., viewed from behind. Nat. size. (p. 30.)

3a. The same, viewed from the front.

3b. Another example, from which the epitheca has been removed, viewed from below.

3c. Dorsil aspect of another specimen, which has not been exposed to weathering.

$3 d$. Outline of another example of the same, showing the sub-triangular form of the calice.

3e. A few of the septa viewed from the exterior, the epithecat being wanting. Enlarged.

3f. Transverse section of a fragment, enlarged. 


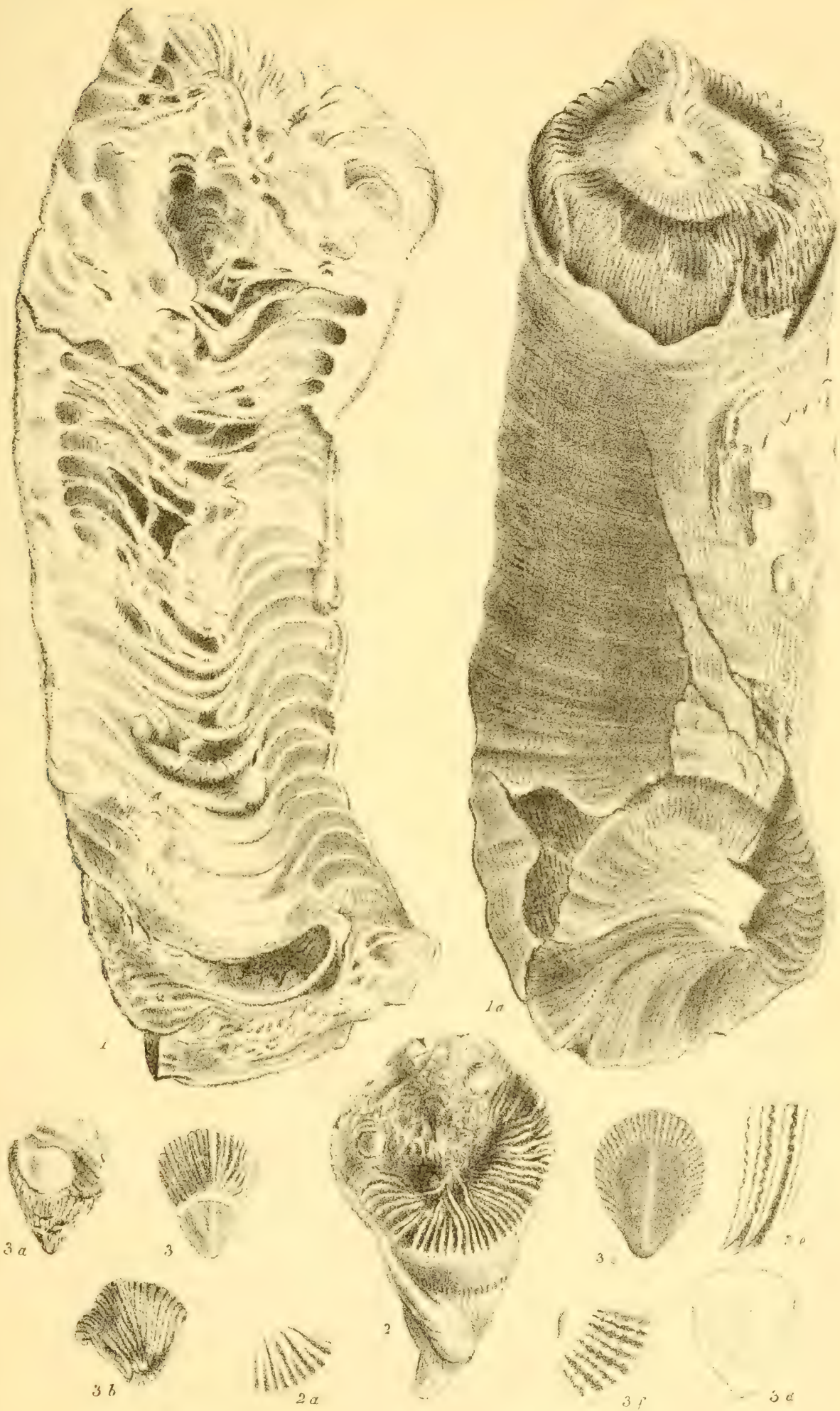






\section{PLATE IV.}

Fig. 1. Zaphrentis Fenestrata, Nich. Nat. size. (p. 22.)

Fig. 2. Blothrophyllum approximatum, Nich. Nat size. (p. 19.) The epitheca has been decorticated.

Fig. 3. Blothrophyllum decorticatum, Billings. A fragment from which the epitheca has been removed. Nat. size. (p. 19.)

Fig. 4. Cuisiophyluu Oneidaense, Billings. A small example from which the epitheca has been removed. Nat. size. (p. 20.)

Fig. 5. Another specimen of the same, in which the epitheca is also wanting. 


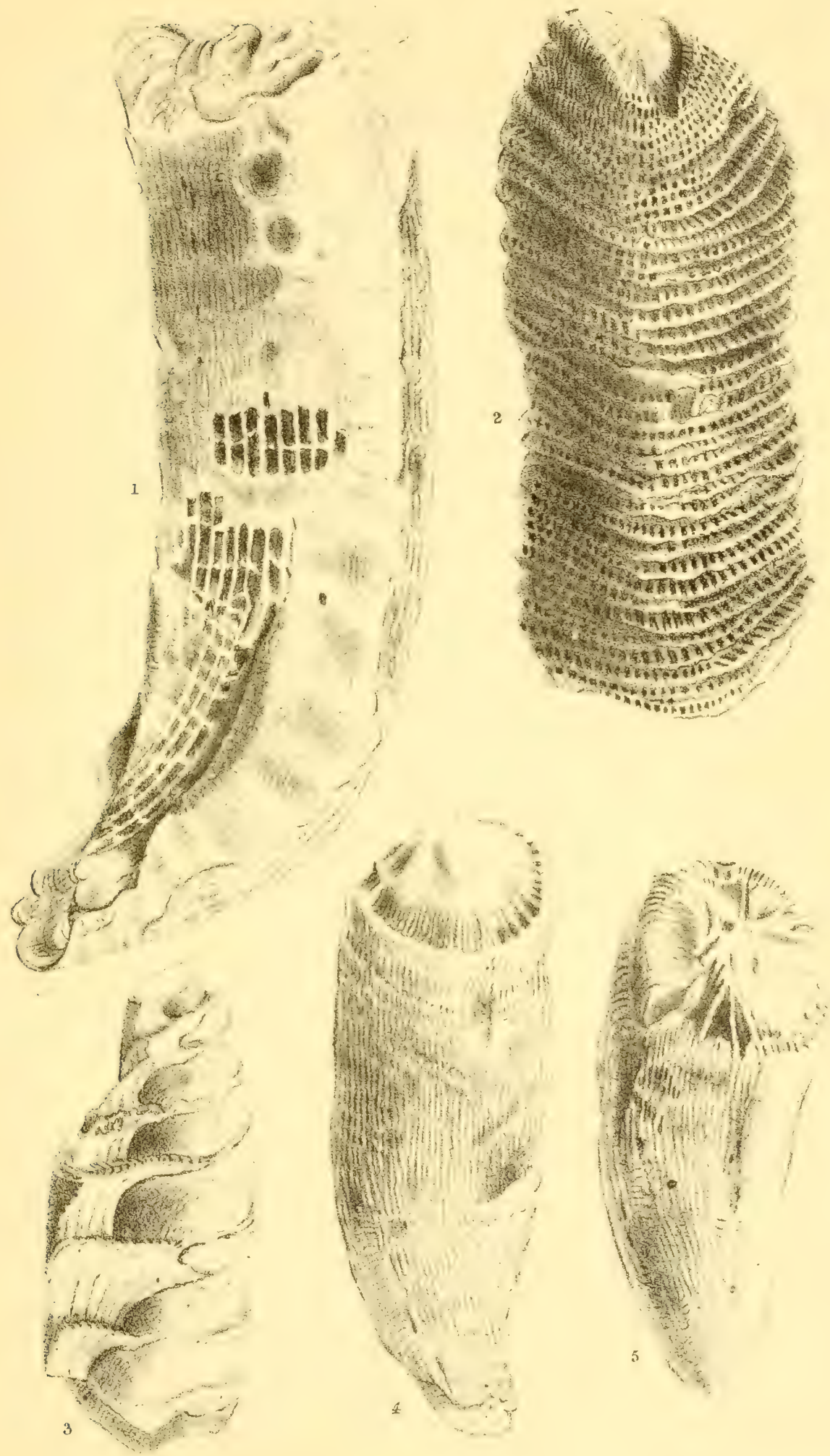






\section{Plate V.}

Fig. 1. Heltophyluum Canadense, Billings. Nat. size. (p. 25.)

Fig. 2. Heliophyllum Cayugaense, Billings. The calice viewed from above. Nat. size. (p. 26.)

Fig. 3. Heliophyllum colligatum, Billings. Upper surface of a fragment. Nat. size. (p. 28.)

$3 a$. Side-view of the same, showing the periodic expansions of the corallites. Nat. size.

Fig. 4. Heliophylum Colbornense, Nich. Nat. size. (p. 25.)

Fig. 5. Diphyphyllum gracile, McCoy. Nat. size. (p. 33.)

Fig. 6. Diphyphyllum stramineum, Billinge. Nat size. (p. 33.) 

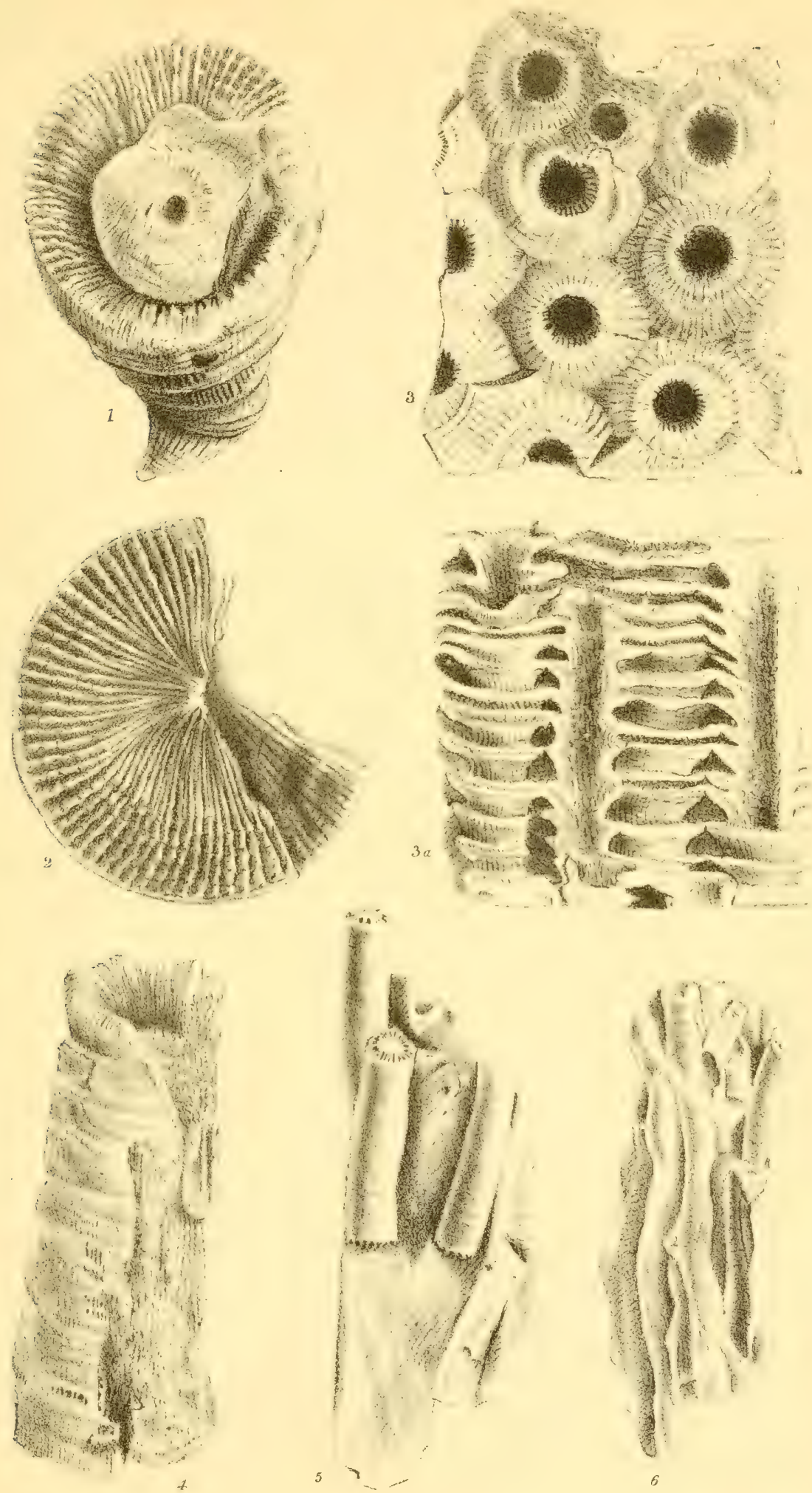




\section{PLATE VI.}

Fig. 1. Diphyphyllum arundinaceum, Billings. Nat. size. (p. 32.)

Fig. 2. Syringopora laxata, Billings. Nat. size. (p. 41.)

Fig. 3. Aulopora tuberformis, Goldfuss. Nat. size. (p. 43.)

Fig. 4. Aulopora umbellifera, Billings. An unusually large example. Nat. size. (p. 43.)

Fig. 5. Eridophyllum Simcoense, Billings. Nat. size. (p. 34.)

Fig. 6. Cystiphyluum Senecanense, Billings. A decorticated and weathered specimen, showing the peculiar composition of the coral out of successive invaginated conical layers. Nat. size. (p. 35.)

Fig. 7. Crstiphyllum sulcatum, Billings. Nat. size. (p. 38.)

Fig. 8. Cystrphyldum Americanda, Edw. \& H. A small specimen from the Corniferous Limestone. Nat, size. (p. 36.) 

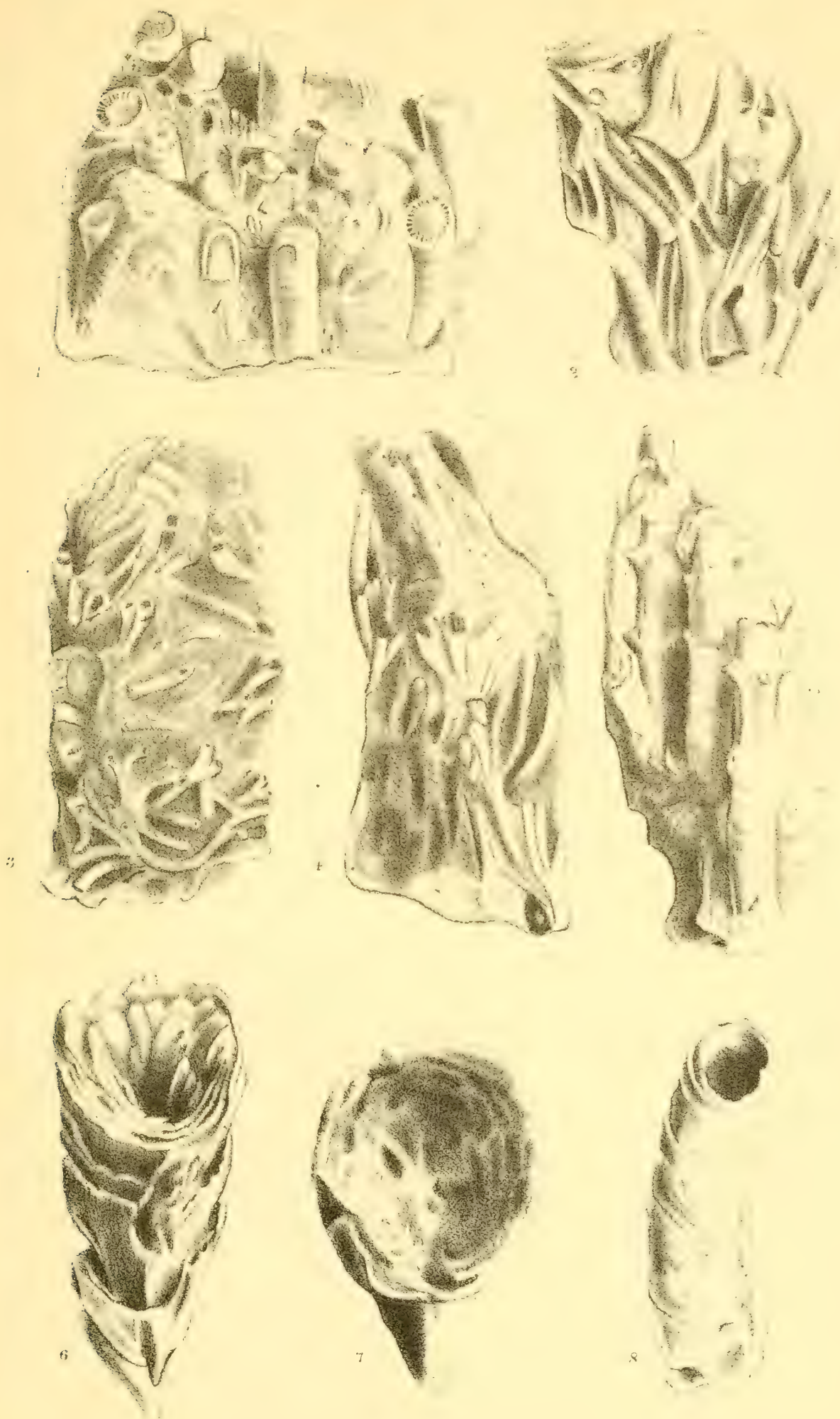




\section{PLATE VII.}

Fig. 1. Alveolitks Bullingsi, Nich. Nat, size. (p. 55.)

Fig. 2. Favosites reticulata, De Blain. Nat. size. (p. 51.)

Fig. 3. Alveolites Rajulosa, Nich. Nat size. (p. 55.)

Fig. 4. Alveolites Selwyni, Nich. Nat size. (p. 56.)

Fig. 5. Favosites dubia, De Blain. Nat. size. (p. 51.)

Fig. 6. Favosites Chapmani, Nich. Nat. size. (p. 52.) This figure does not satisfactorily exhibit the extreme obliquity of the corallites, and the resulting obliquity of the calices.

Fig. 7. Favostes polymorpha, Gold. A small fragment. Nat. size. (p. 50.)

Fig. 8. Favosites Forbesi, Edw. \& H. Nat. size. (p. 48.) 

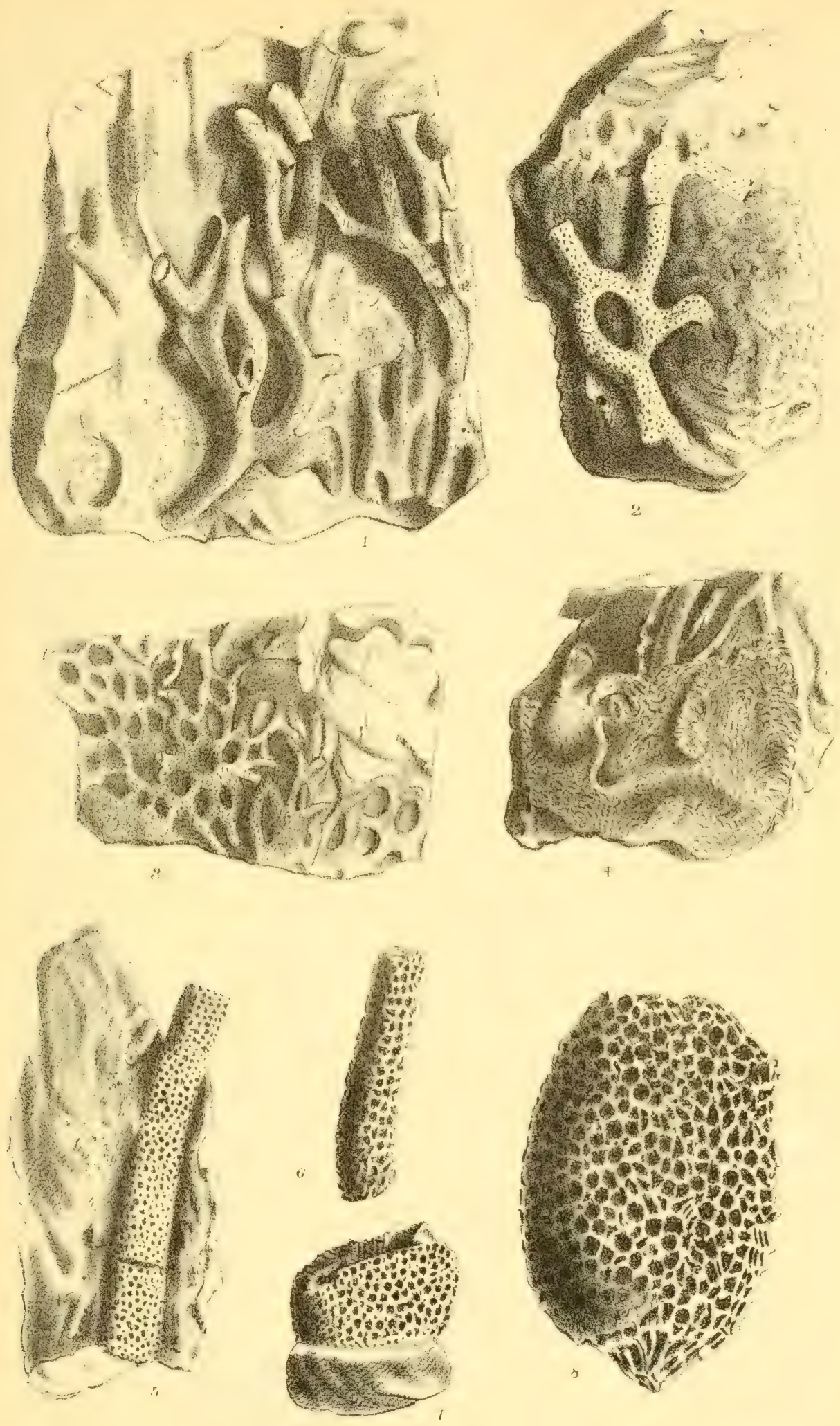




\section{PLATE VIII.}

Fig. 1. Favosites turbinata, Billings. A cylindrical variety. Nat. size. (p. 49.)

Fig. 2. Favosites turbinata, Billings. A turbinate variety. Nat. size.

Fig. 3. Favosites hemispherica, Yandell \& Shumard. Nat. Size. (p. 49.)

Fig. 4. Favosites Forbesi, Edw. \& H. A fragment, in which many of the calices are closed by an epitheca. Nat. size. 

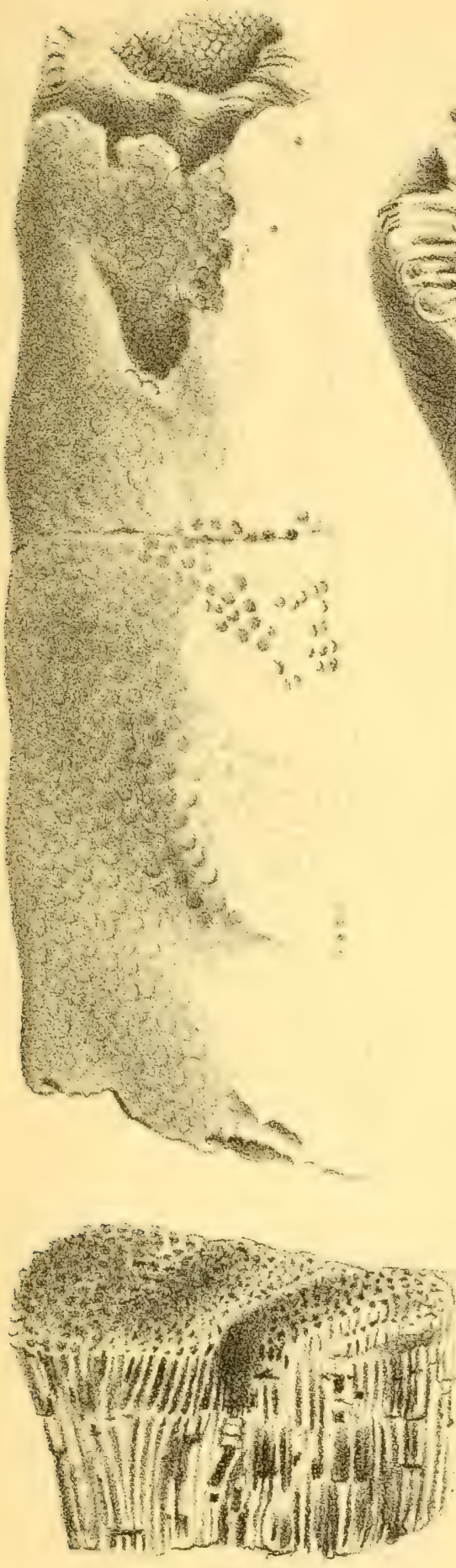

3
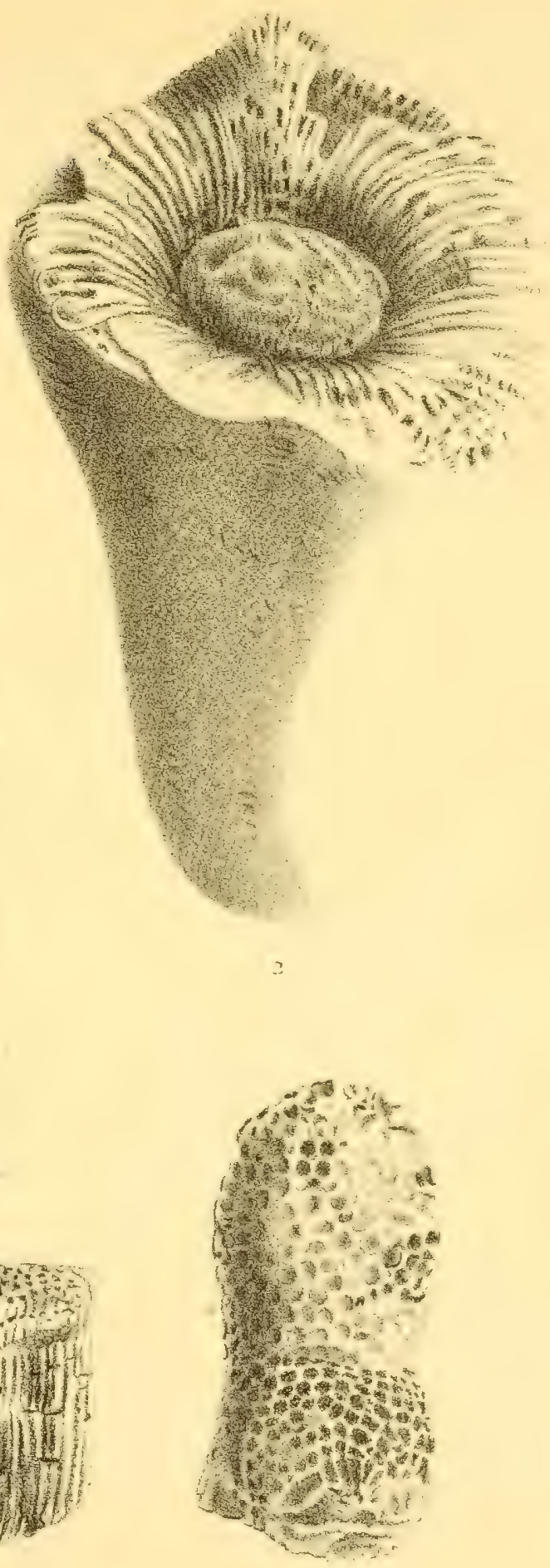







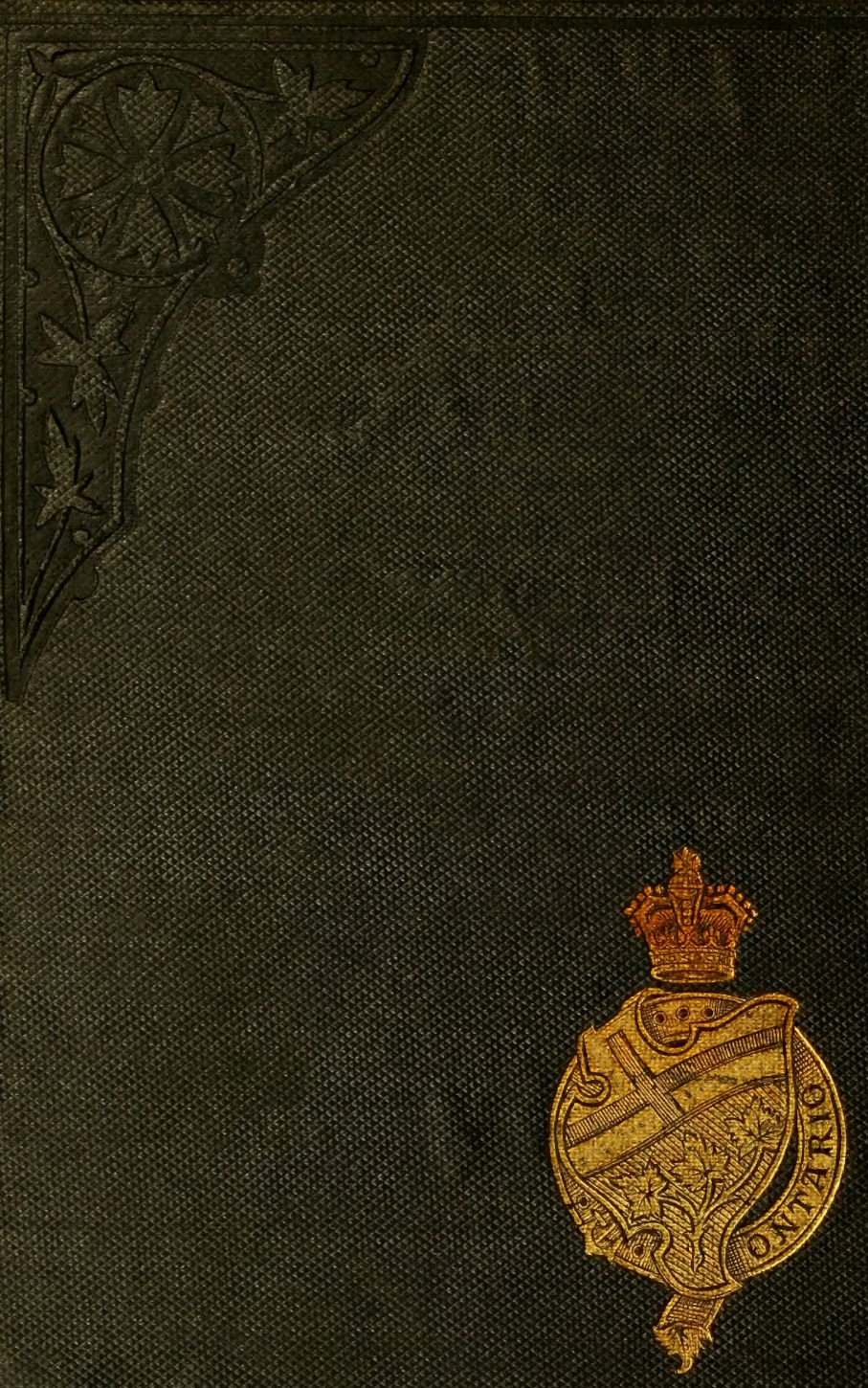

